UNIVERSIDADE DE SÃO PAULO

FACULDADE DE FILOSOFIA, LETRAS, CIÊNCIAS HUMANAS

DEPARTAMENTO DE LETRAS MODERNAS

PROGRAMA DE ESTUDOS LINGUÍSTICOS E LITERÁRIOS EM

INGLÊS

NARA HIROKO TAKAKI

Letramentos na sociedade digital: navegar é e não é preciso.

São Paulo

2008 
UNIVERSIDADE DE SÃO PAULO

FACULDADE DE FILOSOFIA, LETRAS, CIÊNCIAS HUMANAS DEPARTAMENTO DE LETRAS MODERNAS

PROGRAMA DE ESTUDOS LINGUÍSTICOS E LITERÁRIOS EM INGLÊS

\title{
Letramentos na sociedade digital: navegar é e não é preciso.
}

\begin{abstract}
Nara Hiroko Takaki
Tese de doutorado apresentada ao Programa Pós-Graduação em Estudos Linguísticos e Literários em Língua Inglesa do Departamento de Línguas Modernas da Faculdade de Filosofia, Letras e Ciências Humanas da Universidade de São Paulo, para a obtenção do título de Doutora em Letras.
\end{abstract}

Orientadora: Profa. Dra. Walkyria Monte Mór

São Paulo

2008 


\section{Agradecimentos}

A minha orientadora, Profa. Dra. Walkyria Monte Mór, por contribuir com a minha aprendizagem, com suas orientações, com sua inteligência múltipla, com seu conhecimento filosófico expandido, com sua pessoa maravilhosa, os quais permitiram que esse trabalho existisse e que prosseguirá.

Ao Prof. Dr. Lynn Mario Trindade Menezes de Souza, por suas valiosas leituras e críticas as quais me conscientizaram de que é sempre possível expandir as perspectivas.

À Profa. Dra. Anna Maria Gramático Carmagnani, por sua valiosa leitura e crítica na Banca de Qualificação.

Aos professores e aos colegas do programa de pós-graduação do Departamento de Estudos Linguísticos e Literários em Inglês (USP), por suas contribuições, pela amizade.

Aos coordenadores e aos colegas da Universidade Paulista (UNIP) por suas contribuições, especialmente a Cristina Arcuri Eluf Kindermann, por seu apoio e amizade.

Aos participantes desta pesquisa, por suas interações e pela aprendizagem.

Ao Carlos Alberto de Sá Duarte, por sua pré-disposição, leitura, compreensão e afeto.

A minha família, por sua paciência, apoio e humor.

A todos que contribuíram para esta pesquisa. 
Onde quer que o homem sonhe, profetize ou poetize, outro se ergue para interpretar.

(Paul Ricoeur, 1977) 
Resumo

Considerando-se que a tecnologia assume um papel importante nos debates atuais sobre educação em virtude da rapidez e multiplicidade de seus efeitos na sociedade em rede (Castells, 2006), a presente pesquisa enfoca os letramentos como questão crucial à aprendizagem.

O objetivo desta tese é investigar como estudantes universitários, usuários da Internet, de diferentes cursos, em universidades públicas e privadas, constroem sentidos, a partir de seus contextos sócio-culturais, em relação às diferentes formas de prática social e respectivas epistemologias.

Para realizar esta pesquisa, um site foi criado no qual os participantes, hiperleitores, interagiam entre si, escolhendo temas de uma gama de modalidades as quais incluíam imagens, vídeo games, charges, conteúdo de emails, filmes, músicas, lendas urbanas e notícias de outras formas midiáticas.

Esta tese baseia-se em concepções recentes sobre letramentos, principalmente o letramento crítico, como uma prática social. Nessa perspectiva, a construção de epistemologia, realidade e autoria são sempre concebidas como sendo situadas, múltiplas, contestáveis e sujeitas à transformação, conforme salientam Cope, Kalantzis, 2000; Gee, 2004; Lankshear, Knobel, 2005; Muspratt, Luke, Freebody, 1997. Nesta, procuro estabelecer uma conexão entre letramento crítico, hermenêutica crítica (Ricoeur, 1978) e desconstrução (Derrida, 1997).

A conclusão revela que a Internet representa um espaço propício para a construção de conhecimento e sugere, como no título Letramentos na sociedade digital: navegar é e não é preciso, que certeza e incerteza coexistem no processo de navegação, conforme a construção de sentidos dos participantes na qual visões convencionais e mais críticas se mesclam.

Palavras chave: espaço digital, conhecimento, autoria, hermenêutica crítica, educação, 
Abstract

Bearing in mind technology has played a very important role in contemporary debates about education due to its rapid and multiple effects in network society (Castells, 2006), this research assumes literacies as absolutely central to learning.

The aim of this dissertation is to investigate how university students, familiar with the Internet, majoring in various courses, from private and public universities, construct meanings, from and with their historical contexts, in relation to different forms of social practices along with the kind of epistemology embedded with them.

In order to carry out this investigation, a site was built in which the participants of this research, hyperreaders, interacted with each other through choosing to discuss issues from an array of modalities including images, video games, animated jokes, email contents, films, music, urban legends, current news from other media.

This dissertation draws on contemporary notions of literacies, mainly critical literacy, as a social practice. From this perspective, it is assumed that the construction of epistemology, reality and authorship are always contextualized, multiple, questionable and subject to transformations, according to Cope, Kalantzis, 2000; Gee, 2004; Lankshear, Knobel, 2005; Muspratt, Luke, Freebody, 1997. The study connects critical literacy, critical hermeneutics (Ricoeur, 1978) and deconstruction (Derrida 1997).

The conclusion reveals that the Internet represents a propitious space for knowledge construction and it suggests, as in the title Literacies in the digital society: navigating is and is not precise, that both certainty and uncertainty coexist in the process of navigation through the participants' meaning making in which conventional and more critical views are intertwined.

Key words: digital space, knowledge, authorship, critical hermeneutics, education 
Banca 


\section{Letramentos na sociedade digital: navegar é e não é preciso.}

\section{Sumário}

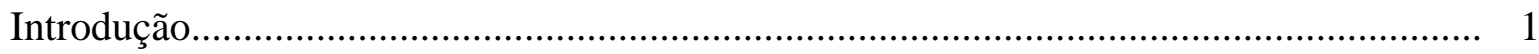

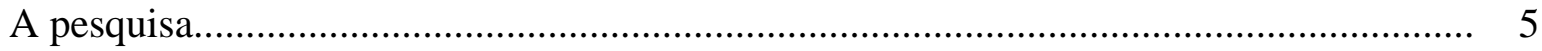

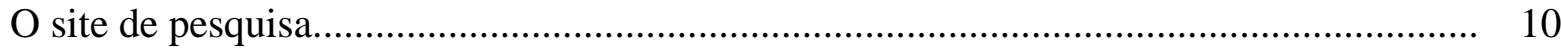

Educação, “'novos”’ letramentos: para ilustrar, os vídeo games................................... 32

\section{Capítulo 1}

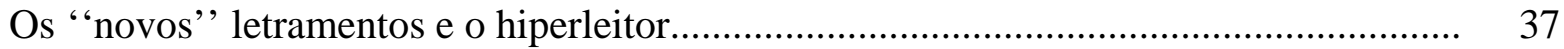

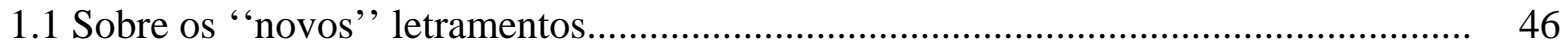

1.2 A hermenêutica crítica e suas relações com o letramento crítico............................... 52

1.3 A questão da crítica nas teorias de letramentos.....................................................

\section{Capítulo 2}

A interpretação na linguagem digital: a construção de sentidos dos hiperleitores

3. Capítulo 3

Letramento crítico e linguagem visual na interação dos hiperleitores.............................. 113

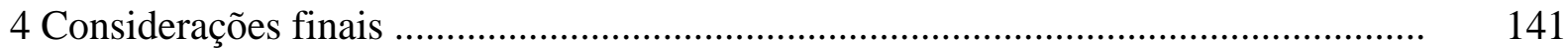

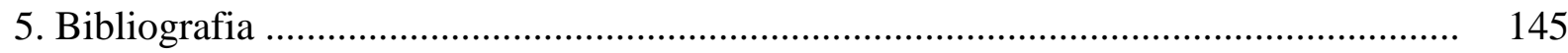

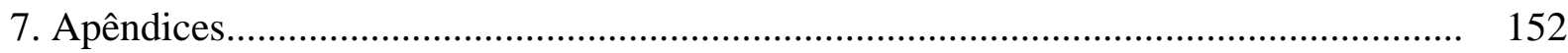




\section{Introdução}

No complexo cenário cultural da sociedade globalizada, imagens, sons e animações, componentes da linguagem multimodal, provocam efeitos que estão transformando relações de poder e conhecimento em face da crescente e rápida expansão dos meios de comunicação em rede.

Dentre as possibilidades de pano de fundo histórico dos grandes debates acadêmicos ganham destaque os da linguagem e sociedade. De tal tendência, novos desafios, na perspectiva de Lankshear, Knobel (2005), são apresentados àqueles que, de forma múltipla, participam das produções de sentido, propiciadas pelo meio eletrônico-digital.

A presente era digital possibilita a convivência com formas variadas e simultâneas de interação humana; inúmeras maneiras de ler, interpretar e agenciar o mundo. Esses novos modos de existir socialmente são, agora, concebidos num tempo-espaço em que as relações textuais complexas requerem diferentes habilidades interpretativas e estratégias que se articulam numa fronteira tênue entre o virtual e o real, segundo concepções de Castells (2006).

Cumpre ressaltar que o advento do texto produzido no meio eletrônico-digital está atrelado às mudanças de ordem sócio-histórica, política-econômica e cultural. Em decorrência, as novas experiências com a linguagem digital acompanham as condições históricas específicas de uma determinada comunidade, de forma que, concepções de poder, epistemologia, hermenêutica crítica, performatividade e agência, demandam novas e constantes revisões.

Salienta-se a contextualização das múltiplas perspectivas em que as produções de sentido ocorrem numa interrelação necessária entre interlocutores-autores e seus locais a partir dos quais conhecimento e performatividade são gerados culturalmente. A esse respeito, Kress (2003) esclarece que, diferente dos princípios da linguagem convencional, como a escrita em meio não digital, a linguagem multimodal depende de uma gama de elementos semióticos tais 
como; gestos, imagens, falas, objetos tri-dimensionais, música, cores, os quais constituem a dinamicidade e incompletude dos sentidos que dali se proliferam. Ilustrativo desse ponto são os conceitos de coesão e coerência, outrora concebidos como padrões de lógica linear, préconcebidos no percurso da esquerda para a direita, de cima para baixo, do simples ao complexo em leituras tradicionais. Respeitadas as potencialidades e as limitações do meio digital, a organização textual se caracteriza por um encontro de multimodalidades; de leitura construída mediante uma interpretação e tomada de decisão ad hoc. Trata-se, pois, de uma prospecção e construção interativa contingencial. Para o referido autor, a noção de modalidade refere-se a uma escolha modal, às decisões relativas ao design e construções de trajetos de leitura (op. cit: 51), estimulando o compartilhar de autoria e não mais a mera leitura.

É desse contexto de fragmentação da constelação multimodal que o fenômeno Internet tem causado impactos nos currículos escolares, motivados por transformações históricas. Segundo Castell, Luke, Egan (1989), cabe indagar sobre como o leitor está compreendendo essas novas mudanças sociais na comunicação, pois, assim como as condições sócio-históricas, políticas e econômicas se transformam, mudam-se as exigências. Num mundo de instabilidade, indagamos sobre o acesso necessário a certas condições, com determinados propósitos e determinado público, sendo que todos esses elementos deverão ser diferentemente reconfigurados para a próxima tarefa. Resulta, assim, a relevância do uso da palavra letramentos, na forma plural, dado que letramento refere-se a um contínuo processo que representa diferentes tipos de habilidades e conhecimentos; um conjunto de práticas sociais que envolvem usos heterogêneos de leitura e escrita com diversas finalidades (Soares, 2006).

Enfatiza-se a complexidade do conceito de letramento. Este é sempre situacional, ou seja, situado em contextos sócio-culturais específicos, os quais demandam responsabilidades diferentes para cada momento. Não se trata de simplesmente adotar e aplicar conceitos e critérios de letramentos já desenvolvidos alhures em um novo lugar interpretativo, conforme a perspectiva de Prinsloo ( 2005).

Nesse sentido, os letramentos não dispensam a necessidade de se reconhecer e de conviver com leituras consideradas neo-liberais, ou seja, aquelas que tendem a privilegiar valores de 
determinados grupos sociais em detrimento de outros, mantendo uma rígida hierarquia de poder. Não se trata, pois, de substituir uma leitura pela outra, conforme salienta Derrida (1997), mas, de compreender a diversidade das interpretações e suas causas históricas.

Como possibilidade de abertura para novos horizontes interpretativos, ir além da mera linearidade socialmente perigosa para determinados grupos sociais, os quais apresentam-se historicamente silenciados em virtude de rígidas relações de poder e saber, num mundo mediado por multi-economias e transculturas, os letramentos possibilitam a observação de que o hiperleitor ${ }^{1}$, sujeito da presente pesquisa, percebe diferentes discursos. E também que, dependendo do momento histórico e de sua leitura, sua construção de significados apresentará efeitos de diferentes tonalidades e implicações sociais. A leitura, nessa perspectiva, é indiscutivelmente uma prática cultural de considerável responsabilidade social, na visão de Gee (1996). Este reforça a possibilidade de minimização das desiguladades sociais e uma das possíveis alternativas na educação viria abranger a expansão da capacidade do cidadão de compreender como questões sócio-ideológicas constroem realidades em detrimento de outras, favorecendo apenas uma minoria elitista.

Os letramentos dizem respeito ao tipo de cidadão e sociedade que podem ser desenvolvidos. Afinal, aprender e ensinar não se reduz a estratégias de aquisição e/ou transmissão de conhecimento ou crescimento natural. Favorável a essa linha de pensamento, Lankshear, Knobel (op. cit.) atestam que o fracasso de tais letramentos convencionais na sociedade devese, em larga medida, ao acesso direto à prática de leitura de forma unilateral em certas instituições. É o que tradicionalmente ocorre por meio de leituras de livros de línguas estrangeiras, nos quais a cultura européia ou norte-americana é tratada como sendo a melhor, a cultura da supremacia do branco em detrimento de outras culturas. Como lidar com questões que propiciem descontruções, reconstruções de identidades, culturas, comunidades e instituições, constitui-se em um debate relevante no que se refere aos letramentos.

Dessa forma, a penetração do meio digital-eletrônico na sociedade, em geral, aponta para a natureza constitutiva, política e cultural de textos digitais, especialmente para o fato de como

\footnotetext{
${ }^{1}$ Denomino hiperleitor, o usuário da Internet e sujeito da presente pesquisa.
} 
relações de poder e conhecimento poderão ser mobilizados por meio do uso de imagens, sons, gestos, animações, cores, a fim de influenciar as maneiras de agir, de se expressar, pensar, sentir, desejar se comportar.

Sem dúvida, a Internet, no contexto pós-industrial, e, pela maneira e concepções pelas quais esta se constrói, possibilita aos hiperleitores outras visões de mundo e, mais do que isso possibilita relacionar esse espaço de co-construção cultural ao mundo público das instituições, às redes entrelaçadas e dinâmicas de poder, às constituições identitárias, às experiências e narrativas, e, portanto, aos posicionamentos críticos de tais leitores. Assim sendo, o espaço cibernético foi concebido como um local no qual os usuários podem criar um espaço de interesses afins (ex.: as comunidades em Orkut, MSN, os Blogs) ao mesmo tempo em que promove reflexões de diversas naturezas: econômica, política, artística, midiática, em tempo quase que real.

O que está em voga na política da educação, diante de um mundo cada vez mais globalizado e socialmente saturado, é a re-educação para enfrentarmos criticamente a nova mídia produzida por tecnologias como a Internet. A indagação do porquê o aprendiz de nível universitário precisa trazer para sua vida diária a preocupação com novas epistemologias de conhecimento e agência, re-contextualizadas faz par com esse mesmo espaço que agora cresce consideravelmente: o espaço digital, no qual indivíduos de diferentes grupos culturais interagem com outros indivíduos também de contextos culturais diferentes de forma construtiva.

Como produtos culturais de histórias híbridas e antagônicas que se entrelaçam, tais indivíduos carregam rótulos identitários complexos, alheios à vontade própria e relacionados à raça, gênero, orientação sexual, idade, portadores de deficiência física, distúrbios de personalidade e atitude (ex.: aprendizes que, apenas por demonstrarem agitação física e rapidez mental, acabam sendo rotulados de super-ativos), locação geográfica, renda, classe social, ocupação, religião, até mesmo variações da(s) língua(s) que se pratica(m). Todos esses aspectos coexistem num mercado linguístico-cultural ambíguo, transpassado por impurezas, em conjunto e em contrapontos mutantes em meio a uma rede de sofisticada tecnologia. 
Diferente de pesquisas eminentemente empíricas para as quais os dados refletem as teorias, a presente pesquisa poderá causar um estranhamento ao leitor no que tange a relação dados de pesquisa e teorias. Se nas pesquisas empíricas a noção de verdade é uma substância a ser encontrada, como se fosse uma essência, uma pureza, nesta pesquisa, a aparente simplicidade dos dados revela apenas traços contextualizados e não evidências e comprovações de teorias. Para tanto, utilizei palavras como sugere, parece, aparentemente, possibilita e não comprova, mostra, evidencia, prova. Parto do pressuposto de que identidade e verdade são conceitos dinâmicos e que, portanto, estão associados a verbos, ações, processos e interações. Tais concepções não são aleatórias, pois, as verdades são contextualizadas. A discrepância entre os dados desta pesquisa e as teorias apresentam um convite à mudança ontológica trazendo, assim, novas epistemologias em meio a construção de conhecimento em rede.

\section{A pesquisa}

Esta pesquisa intitulada Letramentos na sociedade digital: navegar é e não é preciso, (reservo a explicação do título para as próximas páginas) investiga como certos hiperleitores, estudantes de nível universitário, de diversas áreas de conhecimento, de universidades públicas e privadas, interpretam materiais virtualmente produzidos e/ou veiculados (exs.: charges $^{2}$, conteúdo de e-mails, filmes, vídeo games ${ }^{3}$, imagens, músicas, lendas urbanas, notícias, outros). A proposta é investigar sobre esses internautas (hiperleitores), a interação destes com os textos virtuais e analisar seus posicionamentos interpretativos como construções sócio-históricas. Entende-se que esses representam resultados de um processo hermenêutico constante, conforme salienta Ricoeur (1978), um pressuposto que leva às marcas dos contextos de produção e, ao mesmo tempo, de recepção ativa por parte de quem navega no espaço digital.

\footnotetext{
${ }^{2}$ É possível a categoria charge abranja links para vídeos contendo piadas e tiras.

${ }^{3}$ Ou vídeos de jogos e outras animações.
} 
Dessa forma, proponho investigar os posicionamentos de uma comunidade de discentes universitários $^{4}$; observar atentamente as mensagens de e-mails enviadas por eles à pesquisadora, com relação às questões de procedimentos de discussão, dúvidas e sugestões. Nesta pesquisa, a minha função se multiplica como: gerenciadora das contextualizações interacionais, administradora de funcionamento técnico, observadora que acompanha os participantes; agente que seleciona os materiais e intervém nos debates de temas veiculados e/ou produzidos pelo meio eletrônico-digital (exs.: imagens, música, vídeo games, filmes, charges, lendas urbanas, conteúdo de e-mail, dentre outros). Um outro foco central diz respeito à compreensão da relação entre competência meramente tecnicista e a capacidade crítico-interpretativa dos participantes da pesquisa (doravante hiperleitores), ou seja, compreender como eles, que trazem uma bagagem cultural e linguística, interpretam o mundo. A hipótese que norteia este trabalho parte da perspectiva de que os pesquisados já são dotados de capacidade crítico-interpretativo, embora haja a expectativa de que é possível ampliá-la, conforme indicam os aprendizados sobre a hermenêutica da suspeita de Ricoeur (1978). Tal capacidade traduz-se como combustível que é conquistado por meio de exercício de leitura reflexiva e ética, sem perder de vista, entretanto, a percepção da co-existência de maniqueísmos, relativismos redutivos e o abismo logocêntrico ${ }^{5}$ criticado por Derrida (1997). Como dito anteriormente, não se trata de eliminar as dicotomias, mas, sim, refletir sobre as contradições e expandir as visões.

Justifico esta investigação como conseqüência das demandas da sociedade globalizada que requer, cada vez mais, concepções de letramentos que atentem para novas subjetividades, no que tange à prática de leitura de textos multimodais, ou seja, aqueles mediados por uma variedade e simultaneidade de tecnologias, tentando, assim, desconstruir perspectivas interpretativas hegemônicas herdadas das visões colonialistas e imperialistas que estruturam o

\footnotetext{
${ }^{4}$ Tais discentes são concebidos como que interagindo por meio de um avatar. Avatar este que constitui-se da identidade de estudante de nível universitário.
}

Avatar, consoante http://enwikipedia.org/wiki/Avatar_(virtual-reality), refere-se a uma representação das personalidades do usuário de Internet, seja na forma tridimensional em jogos, seja na bidimensional em fóruns. A origem do termo vem do Hindu e Sânscrito nos quais significa a reincarnação de Deus.

${ }^{5}$ Concepção que se refere à recriação de paradigmas ideológicos afins, por meio da mera substituição e/ou troca de um centro pelo outro; o que é central desloca-se para as margens e vice-versa, configurando novamente uma hierarquia. 
ocidente, conforme destaquei anteriormente. Interpreto que poderá haver mudanças no meio social do então produtor-consumidor de tais tecnologias.

É sabido que imagens, sons, animações, muito antes do advento do computador, constituíam componentes narrativos tão significativos quanto a palavra em si, pelo fato da linguagem ser concebida transmodalmente, ou seja, pela sua natureza dinâmica. Na atualidade, o meio digital sugere a confluência de tais elementos dinâmicos. Utilizar a Internet como meio para pesquisa tem suas vantagens (no caso, o acesso às informações se apresenta como uma delas) e desvantagens (o fato de que o conteúdo atraente parece não ter acompanhado a transformação tecnológica do sistema, segundo Castells, 2006:413-521) como costuma ocorrer em outros meios. Como veremos na descrição desta pesquisa, as próprias desvantagens trouxeram, por vezes, subsídios para a minha aprendizagem, não somente como novata e amadora em letramentos, no início da minha pesquisa, mas também como cidadã desse “novo", cenário. Assim sendo, o meu interesse acadêmico pelas interações e construções de sentidos, como prática social no espaço eletrônico-digital, deve-se aos novos estudos de linguagem, os quais ganham visibilidade na complexidade cultural do novo milênio.

A opção por esta investigação que parte da premissa de que há sempre possibilidade para abertura no processo interpretativo, despontou em meio à premente necessidade de me realfabetizar digitalmente e deveu-se igualmente a um processo de criatividade, vistos como possibilidades e desafios de pesquisa educacional, frente às mudanças associadas ao uso das novas tecnologias. Outra motivação para esta investigação foi o fato de eu pertencer a um projeto de letramentos sob a orientação da Profa. Dra. Walkyria Monte Mór ${ }^{6}$, e de entender que as universidades são instituições de geração de conhecimento (ex.: era de articulação entre interfaces pessoais e o ensino online), embora em passos lentos se compararmos, por exemplo, com os conglomerados das empresas de elite, exercendo maior monopólio no

\footnotetext{
${ }^{6}$ Monte Mór é docente e pesquisadora da Universidade de São Paulo. Suas pesquisas recentes abrangem o envolvimento de jovens com tecnologias e as implicações na educação. É membro do projeto de letramento crítico e multiletramentos o qual compreende docentes de universidades da Austrália, Canadá, Grécia, África do Sul e Brasil.
} 
mercado financeiro, como os bancos e as multinacionais. Julguei relevante pesquisar os jovens universitários que já conhecem ou virão a conhecer novas formas de pensamento e interações sócio-culturais modificadas pelas características do momento e pelas demandas tecnológicas.

Como detalharei no próximo capítulo, iniciei leituras que me conduzissem a um aporte teórico sobre letramentos. Autores como Muspratt, Luke, Freebody (1997) partem do pressuposto de que a história tem nos ensinado que letramentos referem-se a um conjunto de práticas culturais que são construídas e reconstruídas por interesses sócio-culturais em permanente conflito, em meio às relações de poder, descartando a expectativa de neutralidade convencionalizada por leituras tradicionais. Assim sendo, os textos são estruturados por domínios sócio-econômicos, representando, portanto, as perspectivas de alguns grupos sociais ao mesmo tempo em que acabam silenciando outras interpretações. Nesse sentido, percebe-se que a natureza hipermodal da linguagem permite instanciarmos outros posicionamentos, evidenciando os discursos dominantes e, ao mesmo tempo, possibilitando que esses sejam criticados e reinterpretados constantemente.

Nessa perspectiva, as perguntas de pesquisa que norteiam este trabalho compreendem: Como ocorre a leitura do hiperleitor no ambiente digital; qual a relação entre hermenêutica e construção de sentido no letramento crítico; o letramento crítico e onavegar propiciam o desenvolvimento do letramento crítico e, neste caso, em que conceito de crítica?

Como frisa o título da presente tese, Letramentos na era digital: navegar é e não é preciso, a tarefa de interpretar já em si constrói-se em teoria, pois revela a produção de conhecimento, conhecimento este como instrumento de poder. Este, agora, não somente por meio da palavra, mas dividindo espaço com imagens, sons e animações, tal como se apresenta em http://www.webnarah.pro.br/old ${ }^{7}$, site criado especificamente para a presente pesquisa, cuja criação será abordada adiante.

\footnotetext{
${ }^{7}$ Esclareço que o site original desta pesquisa era: http://www.webnarah.pro.br, mas este está sendo utilizado para uma outra pesquisa com interações em língua inglesa também. Portanto, mantenho http://www.webnarah.pro.br/old, webnarah.pro.br/old, Webnarah daqui por diante.
} 
Nesse universo fluido, os hiperleitores, sujeitos de pesquisa, interagem uns com os outros, apresentando diversas orquestrações identitárias. Ao fazê-las, vão tomando decisões e articulando repertórios balizados por olhares que reproduzem, ou não, feixes de leituras já consolidadas. No entanto, a própria dinamicidade e complexidade do meio digital e dos objetos-textos de debate fazem com que os intérpretes possam construir narrativas e diferentes matizes. Ao permitir essa reflexão sobre diferentes temas, a natureza maleável da linguagem devolve aos hiperleitores a possibilidade de tornar leituras aparentemente familiares, novamente estranhas, o que remete ao título desta pesquisa: Letramentos na sociedade digital: navegar é e não é preciso ${ }^{8}$. Navegar é, aqui, usado não mais na acepção convencional de direção pré-estabelecida, orientada por uma bússola, mas, sim, como um termo do meio digital que se refere exatamente à pluralidade de destinos escolhidos contingencialmente. Os navegadores/hiperleitores, nos dias de hoje, fazem uso de uma “'bússola” diferente que não garante destinos precisos como na época das grandes navegações européias, pois depende das decisões de quem a articula. Em decorrência, webnarah.pro.br/old se estabelece como um lugar metafórico, sustentando a força da ambiguidade da palavra preciso. Palavra esta que oscila entre a ideia de necessidade e de exatidão, instanciando novas interpretações as quais se abrem por meio do exercício da interpretação para o qual os hiperlocutores são impulsionados, havendo inclusive o risco de se perder o material digital em estudo, diferente do manuseio de livros convencionais em que a materialidade dos mesmos está garantida, permitindo aos intérpretes folheá-los quando quer que necessitem.

\footnotetext{
${ }^{8}$ O título remete a uma temática de Camões: navegar é preciso, viver não é preciso. Esta foi retomada por Fernando Pessoa no poema Navegar é preciso com o verso, Navegar é preciso; viver não é preciso. Caetano Veloso também se refere ao mesmo verso na música Os argonautas. Interpreto que o referido verso alude às condições diferenciadas de caminhos. "Navegar é preciso” remete às navegações européias que contavam com instrumentos de precisão para indicar os destinos aos quais os navegantes pretendiam chegar. "Viver não é preciso” alude à ausência de instrumentos indicadores de rumos a serem tomados, havendo, portanto, um sentimento de incerteza e insegurança para o “navegante”' da vida. Contudo, observa-se que as contingências da vida concebem outros tipos de portos. Se, outrora, na vida real eram seguros, hoje, com o elemento virtual na vida, os portos tornaram-se múltiplos e mutáveis. Enfatizo o fato de que parto da concepção de verdade como sendo um processo interativo e não uma substância, conforme esclarecido na introdução.
} 
A hipótese desta tese, portanto, emerge e submerge a partir da premissa de que nada escapa ao exercício de interpretação, não importando em que meio aconteça. Concebe-se tal premissa porque, conforme citei anteriormente, a natureza maleável e dinâmica inerente à linguagem oferece uma fortuna que permite outras releituras, desconstruções e reconstruções de significados acerca de um determinado texto, a qualquer tempo.

Nesta pesquisa, tentei verificar as ocorrências de leituras na articulação de hiperleitores com o meio digital. Com esse fim, o já mencionado site http//:www.webnarah.pro.br/old foi criado como espaço de investigações que, segundo minhas interpretações, propiciou espaços para interações e análises sobre traços da capacidade crítico-interpretativa, ou seja, traços do estado de letramento crítico dos participantes. Sua elaboração será explanada a seguir.

\section{$O$ site de pesquisa}

Nessa parte, apresento algumas propostas metodológicas utilizadas para a análise das produções de significados no meio digital. Conforme disse anteriormente, esse projeto tem por objetivo investigar como discentes universitários (cada qual com um avatar cuja identificação é a de estudante universitário) compreendem questões relacionadas à leitura do mundo digital, partindo da premissa de que a Internet favorece a produção de conhecimentos. O enfoque, investigação sobre traços do letramento crítico dos pesquisados segundo o conceito de criticidade de Cervetti, Pardales e Damico (2001) pretende verificar como as ações interativas online podem ser compreendidas por teorias acerca de letramentos críticos. Monte Mór ${ }^{9}$ assinala que a investigação de novas linguagens e seus impactos sobre o aprendizado requerem novos instrumentos metodológicos. Logo, a metodologia desta pesquisa foi construída de modo a contemplar essa premissa. Para tal fim, foi criado um site de argumentação com vistas a esse propósito de pesquisa.

\footnotetext{
${ }^{9}$ Palestra proferida em 05 de Junho 2006.
} 
O site intitulado http:www.webnarah.pro.br/old (conforme ilustrado nas figuras 1, 2, 3, 4, 5, 6, 7, 8, 9, repectivamente com imagens B, C, D, E, F, G, H e I) foi criado com o auxílio de um técnico, Gustavo ${ }^{10}$. Em retrospecto, penso que a escolha do nome Webnarah deveu-se à falta de experiência da pesquisadora. Possivelmente um título “auto-explicativo” como $w w w$.letramentos.br surtisse outros efeitos. Webnarah apresenta no home ${ }^{11}$ uma variedade de tópicos que podem provocar o desejo de interagir. Há, por exemplo, uma enquete sobre assuntos polêmicos da vida diária para que o hiperleitor opte por sim, não e talvez. Sei que a pesquisa qualitativa é merecedora de importância ímpar. Entretanto, julguei conveniente apresentar um leque de questões calcadas na atualidade, naquela ocasião (exs.: eleições à presidência da República, crises nos aeroportos brasileiros, filmes, músicas , peças teatrais, jogos eletrônicos da ocasião, entre outros), como uma oportunidade para ampliar a percepção sobre os interesses do usuário e para verificar tendências que pudessem ser significativas para futuras análises.

Com o objetivo de oferecer um home mais dinâmico e colorido, escolhi utilizar recursos do Flash, programa que permite a alternância de palavras, imagens na tela. Assim, selecionei: 1) uma situação simulada em que um indivíduo não concebe sua vida sem acesso à Internet, mesmo nas horas de esforço para condicionamento físico, numa academia (imagem A); 2) utilizei uma imagem de um rapaz se filmando enquanto faz sua própria barba (imagem B); 3) uma imagem de José Serra, um dos candidatos à Presidência da República, fazendo campanha política naquela ocasião, também vinculada a uma sociedade tecnológica (imagem C). As duas últimas imagens foram extraídas de mensagens de e-mail de autores desconhecidos. Uma possível conexão entre as três imagens revela o instrumento eletrônico-digital com o qual as imagens foram produzidas e veiculadas, sugerindo a influência da tecnologia na rotina da vida diária.

\footnotetext{
${ }^{10}$ Todos os nomes dos participantes desta pesquisa foram codificados para preservar anonimidade, exceto quando houve escolha de um participante para manter o nome próprio, como é o caso do citado participante.

${ }^{11}$ Utilizo a palavra home, como abreviação de homepage, para referir-se a primeira página do site de pesquisa.
} 


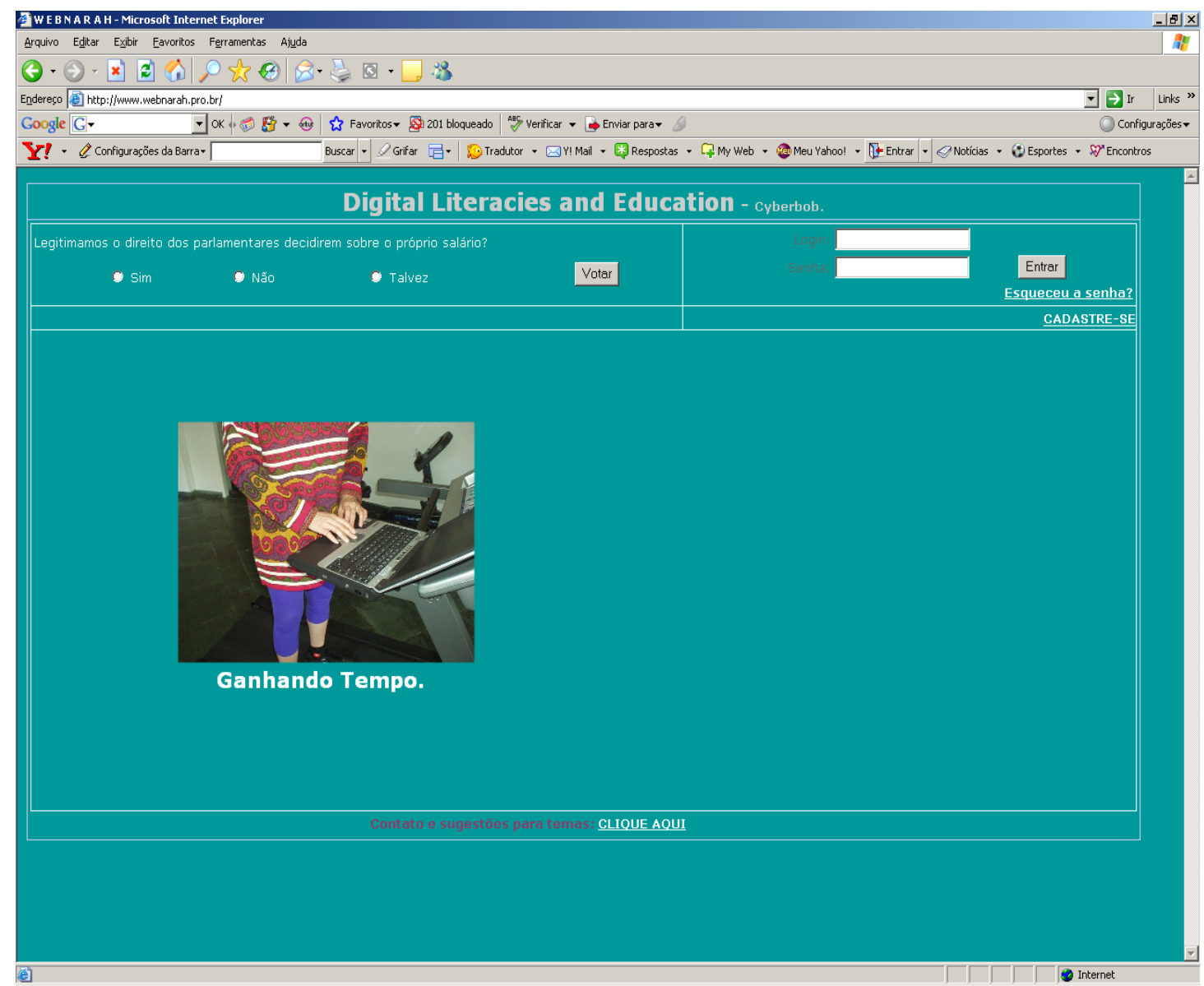

Figura 1: home do site webnarah.pro.br, imagem A 


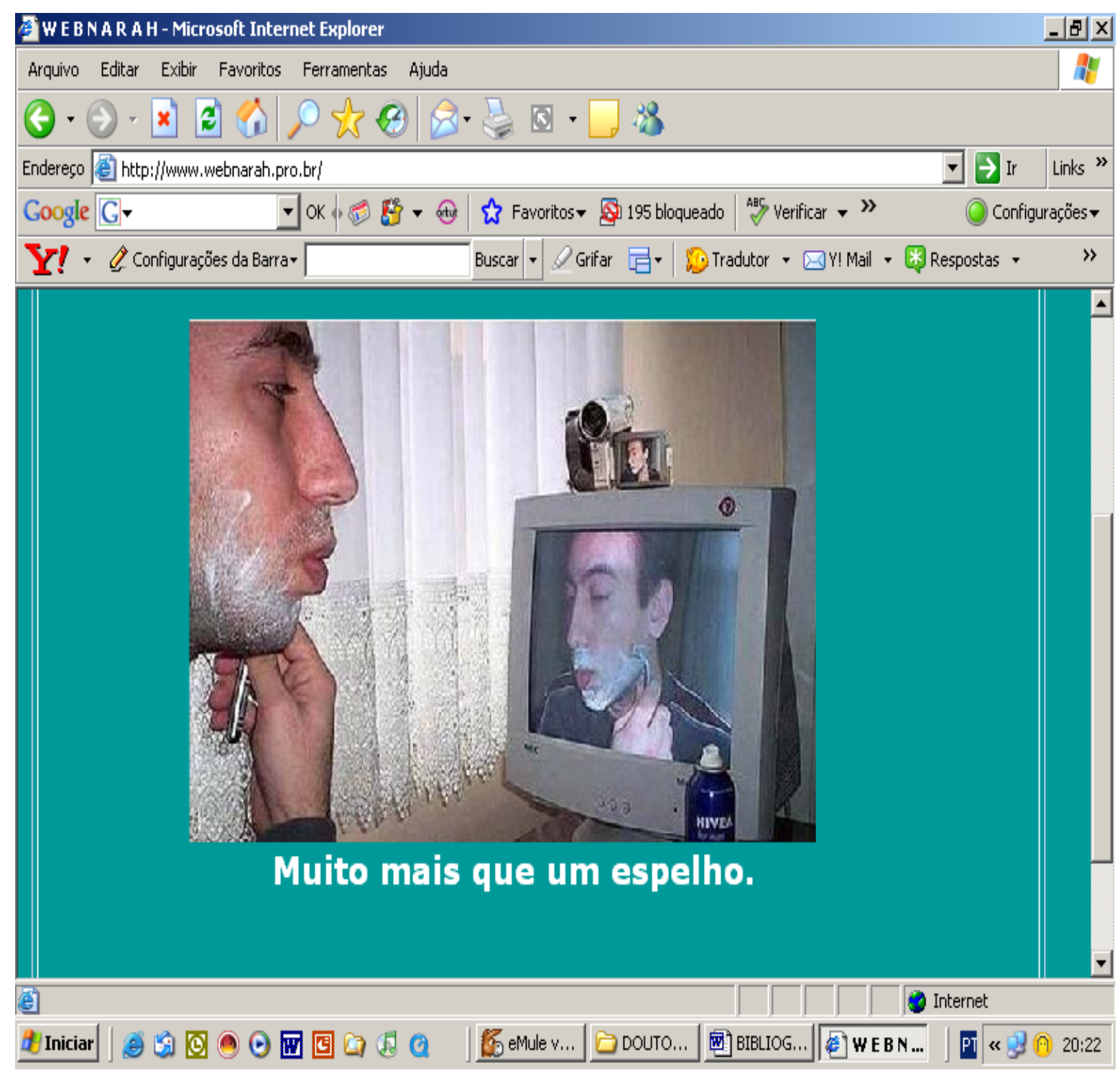

Figura 2: imagem B 


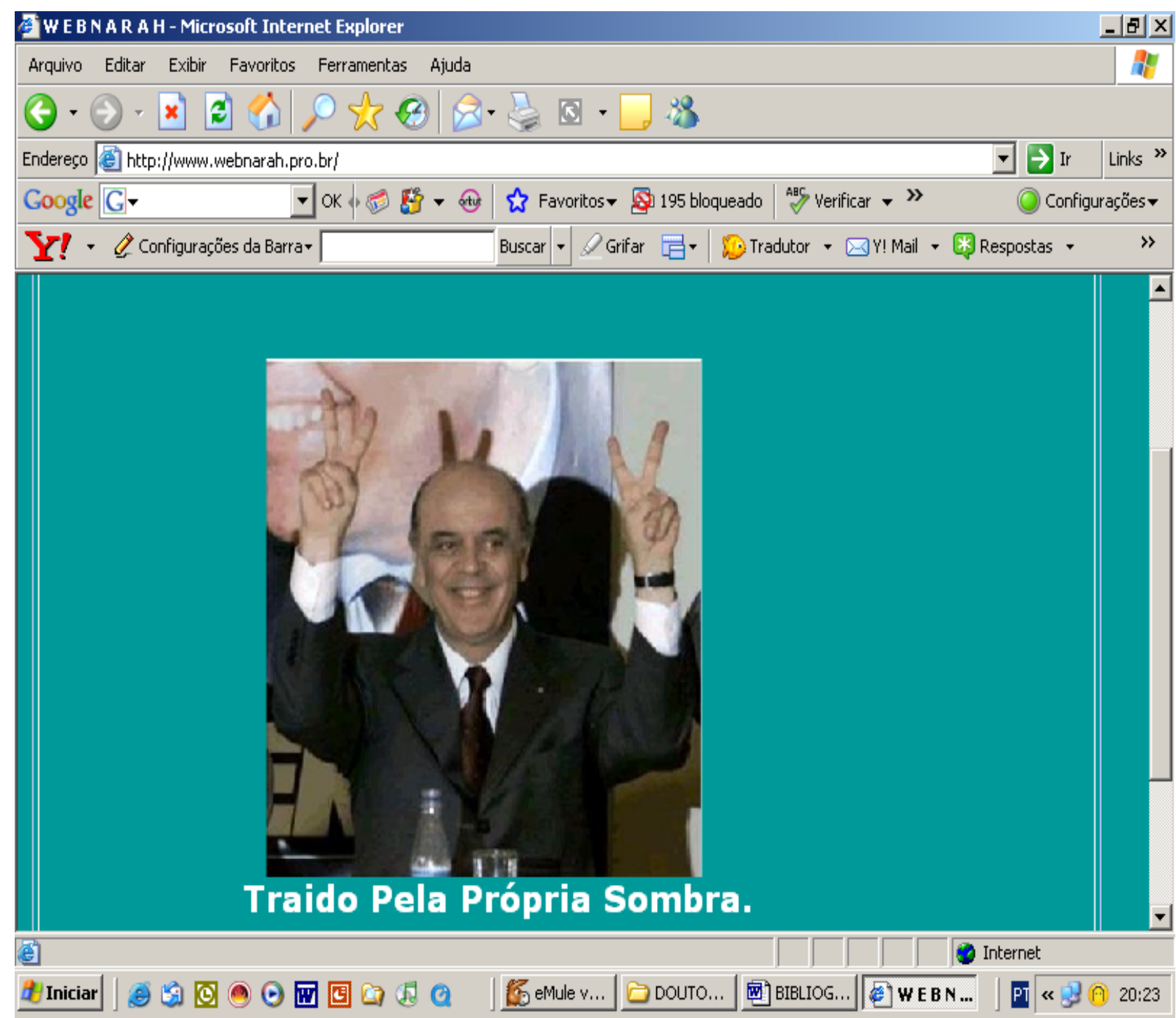

Figura 3: imagem C 
Ainda com o efeito do Flash, os títulos das fotografias se alternavam com uma frase-chamada na página principal do site: A tecnologia cada vez mais presente em nossas vidas.

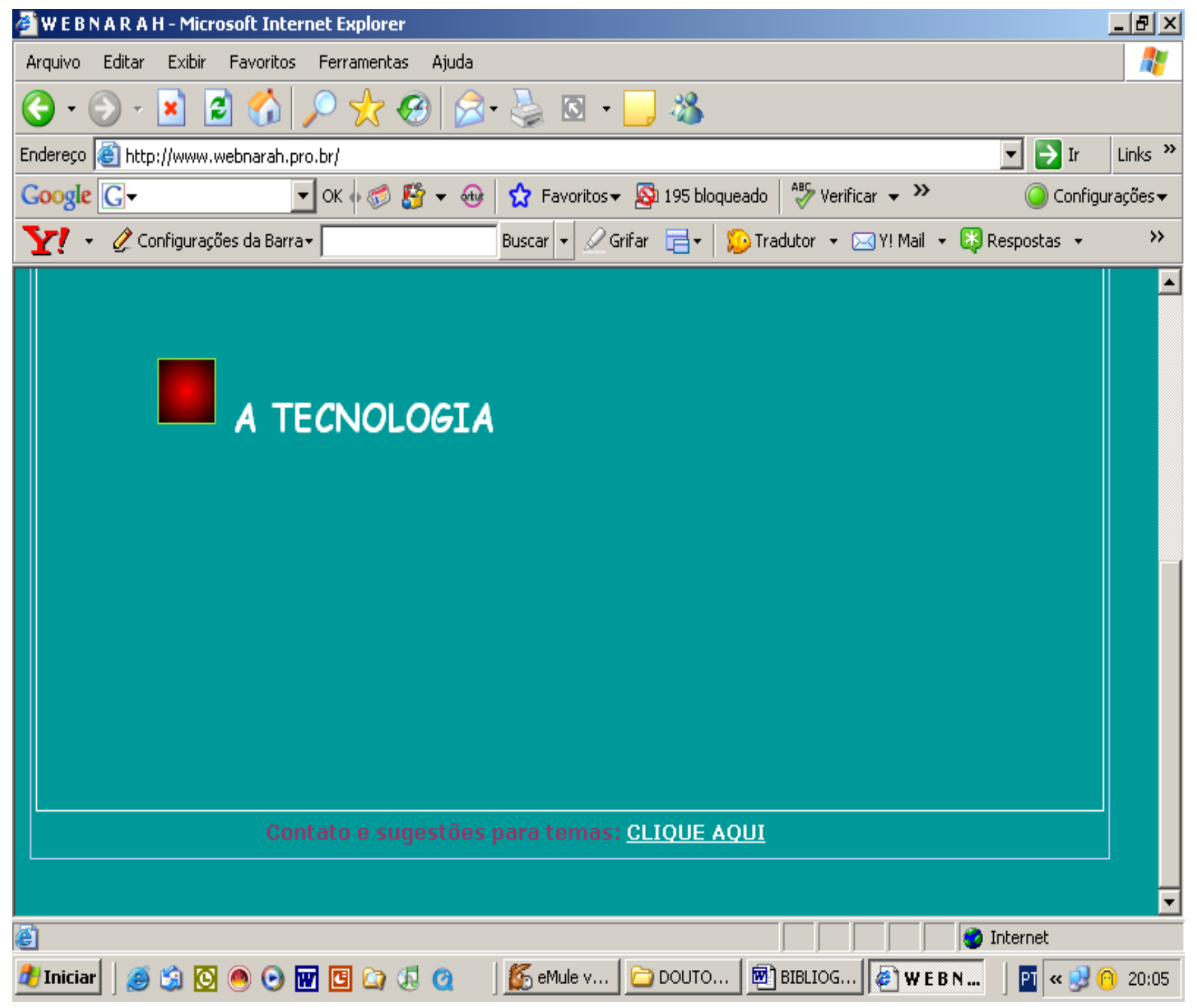

Figura 4: início de frase no home em webnarah.pro.br/old 


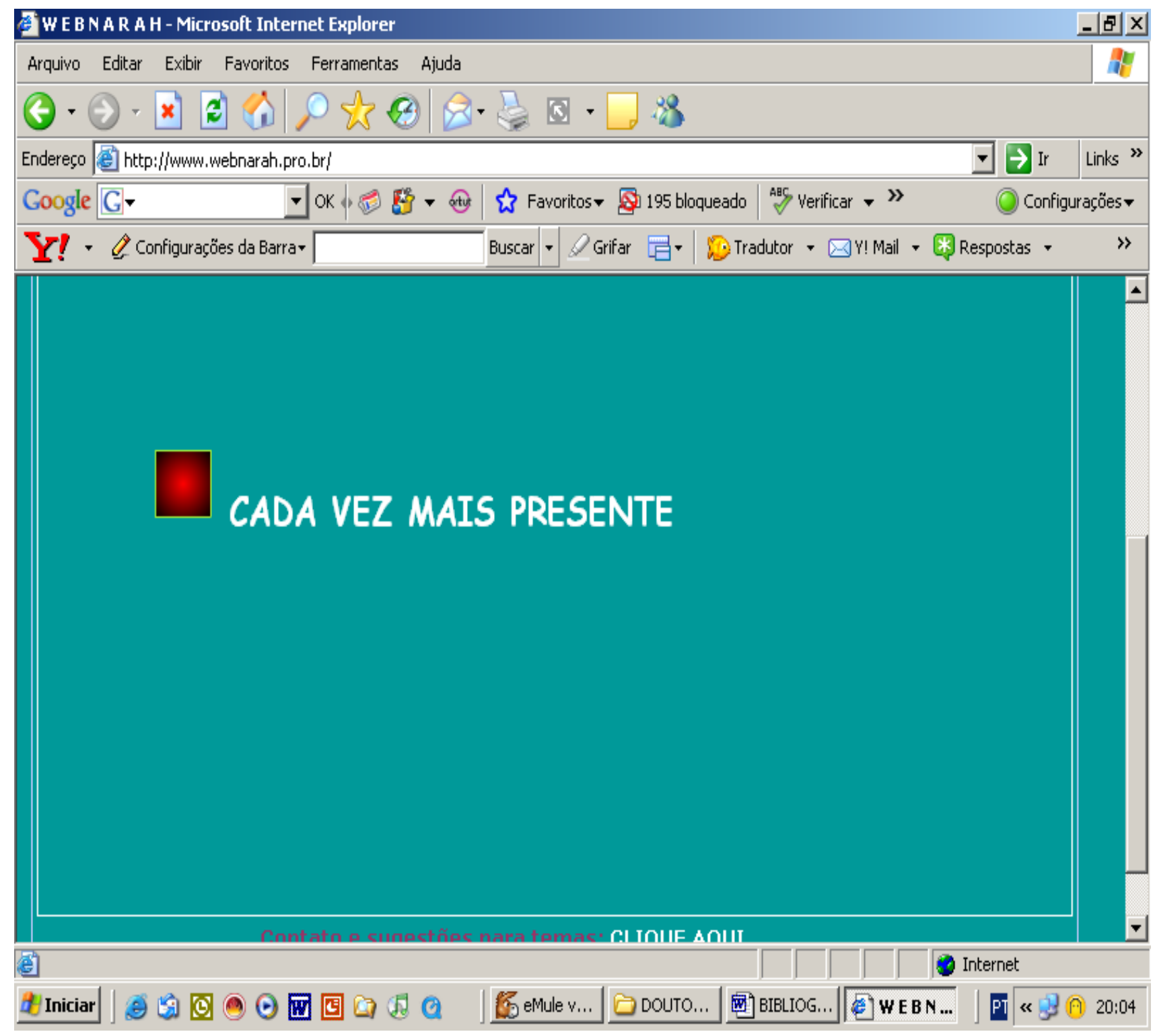

Figura 5: segunda parte da frase 


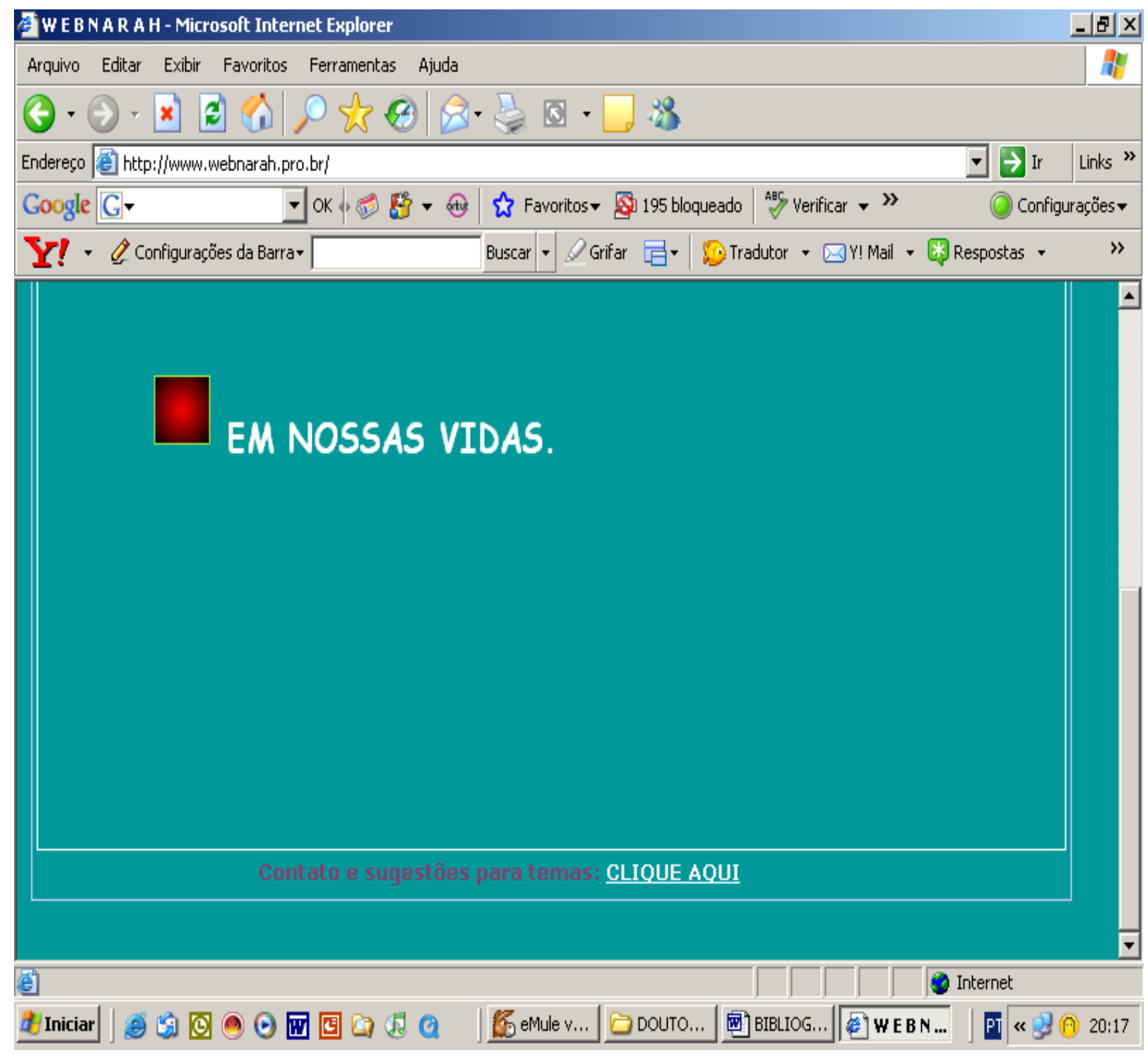

Figura 6: final da frase

Foi deixado espaço para sugestões dos hiperleitores no canto inferior da página, onde se lê contato. Para promover a interação dos participantes no site de pesquisa e por meio dessa interação obter dados para a análise, nove categorias com temáticas diferentes foram apresentadas para a escolha do hiperleitor, quais sejam: charges, filmes, imagens, lendas urbanas, e-mail, músicas, notícias, games e outros. Clicando em uma delas, uma pergunta e/ou enunciado estimulava o hiperleitor a debater, concordar, discordar, expressar comentários, críticas, usando um nome fictício (=login). O conteúdo de pelo menos cinco categorias foi 
renovado, semanalmente, nas manhãs de segunda-feira pela administradora, Margarida ${ }^{12}$, um dos nicknames da pesquisadora deste trabalho. As enquetes foram atualizadas com mais freqüência, duas vezes por semana, dada a velocidade do universo em que a mídia opera. O endereço administrativo do referido site é: http://www.webnarah.pro.br/old/adm.php.

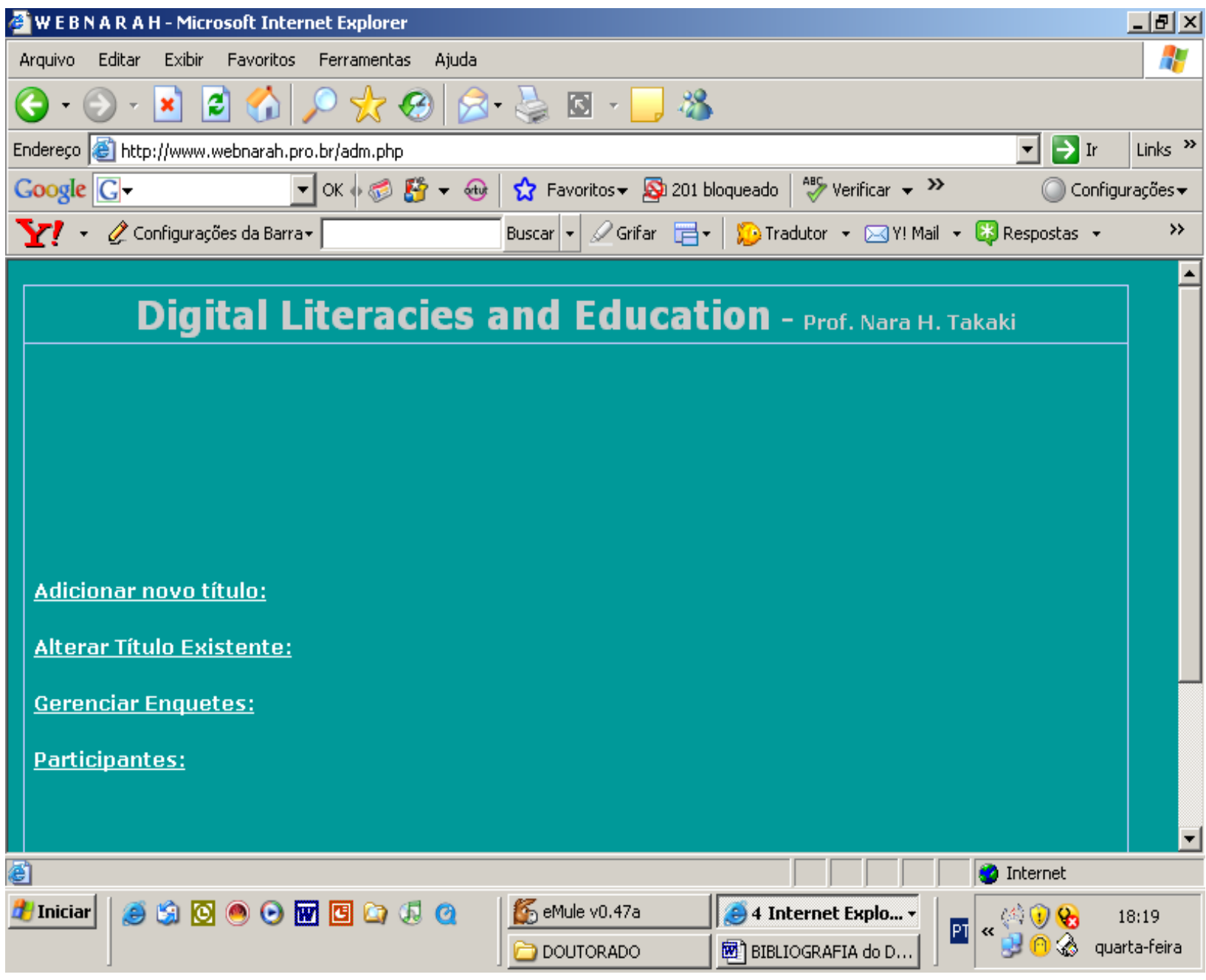

Figura 7: homepage administrativo

${ }^{12}$ Os nicknames Margarida e Cyberbob foram criados para as respectivas funções: a de mera gerenciadora do site e a de "moderadora" das interações. Entretanto, os dois nicknames acabaram sendo utilizados nas interações. 


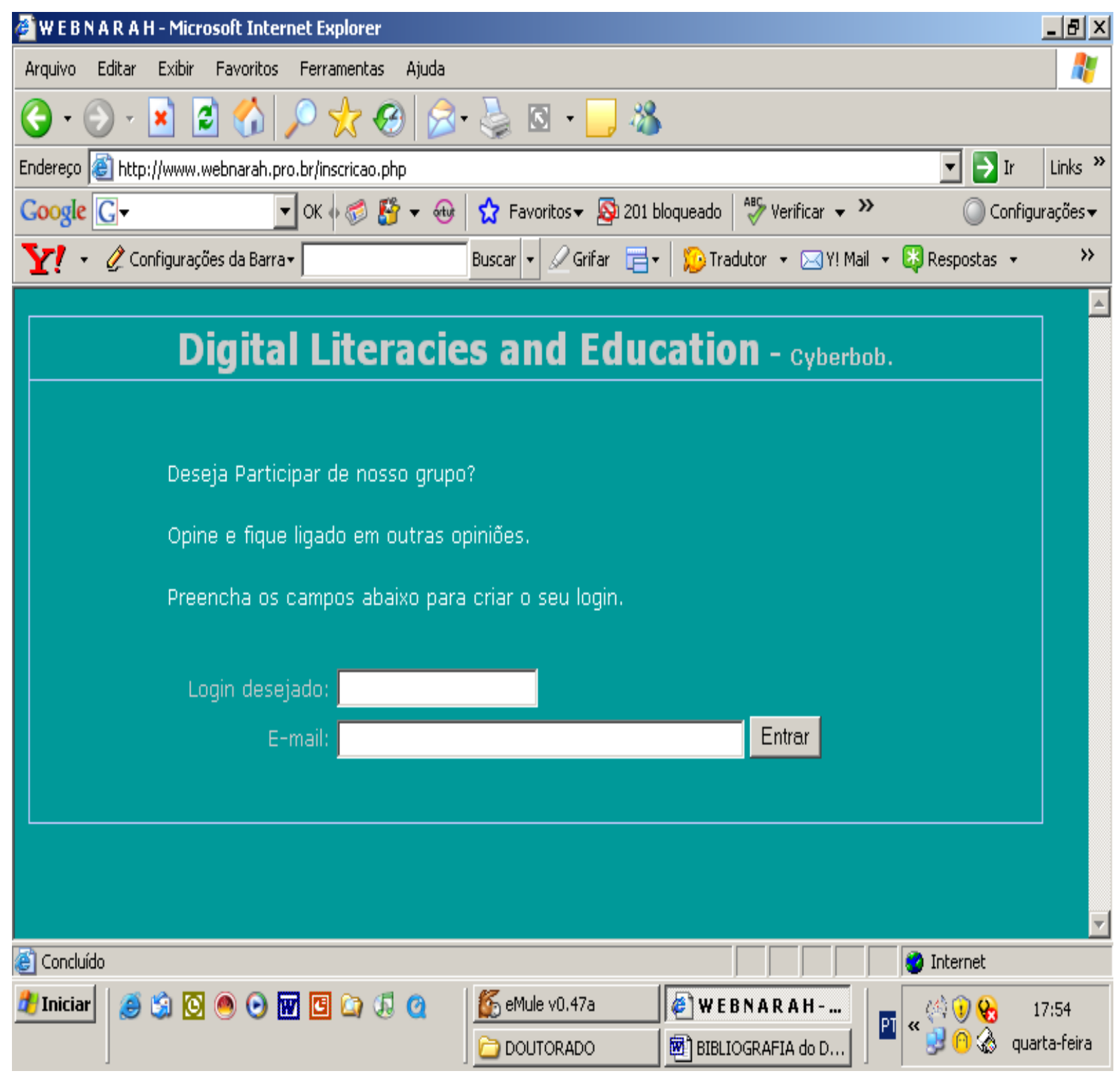

Figura 8: link para auto-cadastramento 
Digital Literacies and Education - Cyberbob.

CHARGES | FILMES | IMAGENS | LENDAS URBANAS | EMAI L I MÚSI CAS | NOTÍ CIAS | GAMES | OUTROS

I magens:

0

De olho nas galerias

Descreva o trajeto que você vizualiza

nesta imagem clique aqui>

Comente:

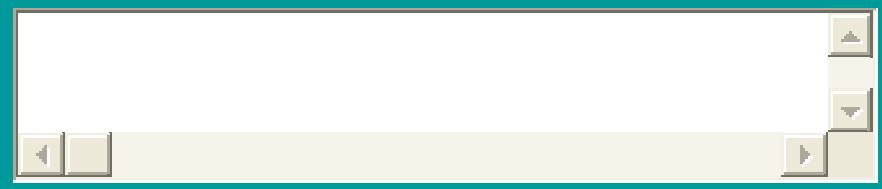

Enviar

Limpar

Temas Anteriores:

- De olho nas galerias

- Fotos do home

- Frase de caminhão

- Magritte

- Babe 


\section{- Vou de férias para as praias}

\section{Comentários:}

\section{jean_unesp}

Um trajeto aéreo, por sobre a paisagem presente na pintura principal, até regressar à perspectiva real do homem que vizualiza a obra.

Figura 9: ilustração da categoria imagem.

A pesquisadora assumia o controle de quem se cadastrava, por meio de mensagem eletrônica que lhe era enviado (ex.: Sweet_Girl acaba de se cadastrar em Webnarah). Alguns recursos técnicos foram criados para que eu pudesse administrar o site. As tarefas incluiam: 1) verificar a lista dos participantes cadastrados (estes, obviamente, sem direito ao gerenciamento do site); 2) alterar, adicionar enquetes e/ou conteúdo das categorias; 3) auxiliar hiperleitores com dificuldade em se cadastrar. Com a finalidade de dialogar com Gustavo a respeito das orientações tecnológicas do gerenciamento do site, houve a necessidade de mantermos o 
mesmo login (Margarida) e senha, para que ele próprio tivesse acesso imediato a Webnarah e fizesse as devidas modificações periódicas. Tanto as minhas solicitações, como as dele, ocorriam via e-mail. Houve momentos, no início da pesquisa, em que Gustavo fez testes de verificação do funcionamento do site (ex.: votando numa determinada enquete, várias vezes, tendo que, mais tarde, apagar suas marcas e também reordenar a sequência dos comentários dos hiperleitores, por ordem cronológica de iniciativa). Isso ocorreu pelo fato de que um dos participantes colaborou no sentido de me alertar sobre tal problema, por meio de mensagem eletrônica.

A divulgação do site de pesquisa ocorreu por meio de propaganda realizada presencialmente, mediante um documento que explicitava a proposta de pesquisa, com espaço para que os interessados em nela participar, voluntariamente, pudessem escrever seus nomes e e-mails (vide apêndice 1). Alguns colegas meus que lecionam em universidades foram contactados por e-mails solicitando que divulgassem a proposta de pesquisa e me enviassem os nomes e emails dos alunos interessados na participação. O mesmo procedimento, via e-mail, ocorreu com relação a alguns universitários de meu conhecimento. Enviei-lhes uma mensagem (vide apêndice 1) esclarecendo que se tratava de uma pesquisa de doutorado e que estavam convidados a participar dos debates on-line sobre temas variados pelo menos uma vez por semana, mediante um cadastro, com senha e nickname ${ }^{13}$. Frisei que tais dizeres produzidos pelos participantes seriam usados como insumos de minha pesquisa, mas que a anonimidade talvez se efetivasse por conta do uso de nomes fictícios, por parte dos hiperleitores. Um ou outro optou por se declarar, usando o nome real. Escolhi como meu próprio login, Cyberbob, porém, creio que isso tenha sido desnecessário, sendo, portanto, resultado de um ato falho da minha parte, já que todos os participantes sabiam quem era a hiperleitora-pesquisadora.

A primeira consideração por essa escolha deixa transparecer a minha pré-disposição para me permitir adentrar um universo em que minhas identificações pudessem proliferar, tanto quanto a dos participantes. Entendo, outrossim, que a mudança de gênero talvez pudesse causar estranheza, sob pena de afastá-los das interações ou dar sinais de que o simulacro ia se tornando realidade. Cabe ainda lembrar que a Internet convive com sua natureza flexível, o

\footnotetext{
13 Optei por um site, de conteúdo típico de site aberto, acessado por senha para a obtenção dos endereços eletrônicos dos participantes no cadastro para eventuais contatos.
} 
que Snyder (1997:52) denomina de promíscua, ou seja, isso nada mais representa que a sua energia geradora de inovações e significações culturais ad infinitum, sua capacidade inerente de recombinar elementos intertextuais, aberta para novas relações, atualizações, dividindo autoridade, produção e autoria com o hiperleitor, nessa constante reconstituição de hipertextos. Na medida em que não necessariamente propicia constrangimentos, a multimídia evoca a maioria das expressões culturais em toda a sua diversidade e simultaneidade, mantém as chamas de uma relação vivíssima e íntima com a mídia audiovisual, a mídia impressa, culturas diversas, entretenimento e informação.

Acreditava no início que os voluntários deveriam me enviar nome completo, e-mail, nome fictício, universidade na qual se encontravam inseridos para o meu gerenciamento e conhecimento da comunidade que ali se formaria ${ }^{14}$. Nem sempre obtive as respostas e pude refletir que isso não deveria me causar preocupação, pois, no mundo virtual-real as identidades se apresentam, insofismavelmente, como avatar. Vale lembrar que pistas contextuais que influenciam a dinâmica do grupo estão, aparentemente, mais atenuadas ou aparecem com menos frequência na troca eletrônica. Carecemos de informações sobre posição social, raça, idade, aparência, gênero, a menos que os hiperleitores decidam declarálas. Um hiperleitor poderá ter informações sobre os outros, mas, normalmente, algumas dicas de fato são reveladas sublinearmente nesse tipo de interação. Como previsto, houve momentos de comunicação online plenamente espontânea e informal ao redor de valores e interesses em comum, ainda que temporariamente. Assim, Hine (2000), Leander, McKin (2003) que desenvolvem metodologias de pesquisa etnográfica voltadas para o ambiente virtual não estabelecem recomendações quanto ao prazo de registro de dados para esse tipo de investigação. Procurei ressaltar que a pesquisa teria uma duração de aproximadamente dois meses, mas, isso dependeria da relevância dos insumos, de acordo com a minha avaliação das interações no referido site. Esse prazo baseia-se nas recomendações da pesquisa etnográfica qualitativa, ao tratar do tempo de descrição das comunidades sob investigação (Cavalcanti, Moita Lopes, 1991).

\footnotetext{
${ }^{14}$ Não houve fornecimento de dados pessoais detalhados sobre os participantes, exceto informações sobre curso: (Letras e Tradução em Língua Inglesa, Turismo, Relações internacionais, Ciência da Computação e respectivas universidades; pública e privada).
} 
Para um observador atento, o mapa de Webnarah sugere valores culturais de meu locus de enunciação $^{15}$, bem como os de Gustavo, cuja perspectiva reforçava formas de exercer demasiado poder sobre os participantes, por meio de tabulações, categorizações rígidas, resultados quantitativos. Mas, isso, gradualmente, modificou-se pelas minhas intervenções. Em resposta a Gustavo, esclareci que não se tratava de um site comercial, mas, sim pedagógico e que os objetivos da pesquisa enfocavam os processos e não somente os resultados. O que foi selecionado e o que ficou de fora, em termos de materiais, a composição estrutural e a visualidade, cores, tamanhos de imagens, afetariam os arranjos mentais de cada participante. Por exemplo, as “categorias”' talvez pudessem ser pensadas de forma estanque sem qualquer forma de permeabilidade entre as mesmas. Numa discussão presencial semelhante à da sala de aula, isso provavelmente ficaria mais diluído com temas afins sendo reciclados e correlacionados com mais freqüência.

A metodologia que norteia esta pesquisa intenta ser exploratória, pois, estão em jogo conhecimentos "novos" os quais requerem novas metodologias de pesquisa, expandindo, assim, as compreensões sobre a linguagem como prática social. Segundo Buzato (2007), autores como Hine (2000), Leander, McKim (2003) advogam a favor do desenvolvimento de metodologias interpretativas de cunho etnográfico que desestabilizem conceitos convencionais que adotam o tempo-espaço online e o tempo-espaço offline como sendo fixos e independentes entre si. Leander \& Mckim (2003: 218), declaram que:

As teorias interconectadas de espaço não concebem os espaços-tempos da vida moderna separados do novo espaço desenvolvido por práticas e tecnologias da Internet, tampouco admitem uma mera lógica de substituição - a de que um novo espaço emergente pudesse substituir um espaço dominante de outrora. Ao contrário, as teorias relacionais defendem uma perspectiva baseada em recentes estudos etnográficos sobre as práticas de Internet: os

\footnotetext{
${ }^{15}$ Todo interlocutor interage deixando marcas, traços significativos de sua cultura. Tais traços são influenciados pelas condições sócio-ideológicas e econômicas a partir das quais ele se socializa. A esta posição que ele ocupa, no momento da interação, Bhabha denomina de lócus de enunciação (1994). Daqui em diante, lócus, loci.
} 
espaços sociais emergentes das práticas digitais apresentam-se interconectadas, de forma complexa, com espaços sociais. Estes como sendo "anterior a" e "fora da" Internet. ${ }^{16}$

Verifica-se que uma das preocupações dos referidos autores é justamente desmistificar o fato de que a Internet não é arredia à prática social da vida diária de seus usuários. Essa adaptação etnográfica para pesquisas realizadas no meio eletrônico-digital sustenta-se a partir do princípio de que tais espaços (online e offline) são indissociáveis. Como extensão desse raciocínio, os mesmos autores adotam a terminologia etnografia conectiva, ou seja, aquela que concebe as práticas sociais de forma constitutivamente híbridas, co-construídas. Dito de outra forma, tais práticas são processos contínuos imbuídos em relações de poder e maleabilidade histórica. Não se trata de introduzir uma metodologia divorciada das limitações e problemáticas que a etnografia apresenta na análise das práticas em espaços julgados mais físicos (leia-se anterior à Internet).

Uma preocupação emerge com a adoção de noções da etnografia qualitativa (Clifford, 1992) para o meio eletrônico-digital: o que acontece com os significados e usos de elementos como lugar, conhecimento sobre identidades locais e observação dos participantes? Leander, McKim (Apud Buzato, 2006) respondem-na através do cenário social de Spradley (1980), para o qual deverá haver um lugar, atores e tarefas. O lugar social existe em função da interação e co-existência dos atores e tarefas. O pesquisador entra em contato com um determinado lugar social (ex.: comunidade), observa-a e poderá interagir com a nova cultura que ali emerge. O lugar é construído por meio de estratégias culturais que se movem e transformam graças às interações múltiplas e simultâneas, caracterizando a fluidez das produções digitais. A percepção de pistas contextuais não verbais (exs.: animações, imagens) e suas relações com o verbal, está a serviço da expansão analítica e interpretativa das práticas

\footnotetext{
16 Tradução minha. Original: Relational theories of space would not assume the space-times of modern life would be held apart from new spatial relations developing through the practices and technologies of the Internet. Neither would such perspectives assume a simple replacement logic- that a new dominant space could substitute for an old dominant space. Rather, relational theories would be more supportive of a view that we believe is emerging from current ethnographies of Internet practices: that the emerging social spaces of Internet practices are complexly interpenetrated with social spaces considered to be 'before' and 'outside of' the Internet.
} 
culturais nesse meio. O etnógrafo virtual, por assim dizer, e seus participantes de pesquisa, constroem identificações diferentes que não seriam possíveis outrora.

Uma outra questão tratada por Leander, McKim (2003:216) reporta-se ao fato de que parte da autoridade da produção etnográfica está diretamente relacionada com a interação entre informantes e pesquisador, como participante, o que para tais autores poderá ser problemático na medida em que questionam a autenticidade dos participantes quando o pesquisador juntase ao grupo on-line e participa dos eventos sociais lá construídos. Diante disso, eles propõem encontros presenciais para triangular a autenticidade dos participantes, mesmo reconhecendo ser esses encontros atípicos na maioria dos casos de pesquisa. É então que Hine (2000) remete-nos à ideia de identidade como uma instância a ser negociada e sustentada na própria situação contingencial em que as construções de significado ocorrem online e não apegadas à presença física do participante.

Em concordância com Hine, complemento que as identidades que o meio eletrônico-digital favorece já são concebidas mediante o que fora construído anteriormente à pesquisa online, pois, não há como não ser afetado pelas produções midiáticas da vida: a televisão, os jornais, as revistas, o rádio, os celulares, os relógios, os veículos de transporte, todos já operando com recursos tecnológico-digitais. Ocorre uma espécie de inclusão social involuntária e coletiva. Mais do que mera dialética, a prática social agora não se restringe a uma via de mão dupla, mas sim, de várias vias que se articulam e interconectam simultânea e constantemente.

Enfatizo que o caráter exploratório, experimental desta pesquisa também se apóia em: 1) um aporte teórico; 2) objetivos; 3) um espaço de afinidades (Gee, 2004). Este último caracterizado pelo encontro e desencontro, concordâncias e discordâncias de hiperleitores com interesses minimamente compartilhados. O espaço de afinidades é, antes de tudo, um artefato cultural em que os participantes demonstram interesse e passam a integrar um jogo discursivo, reconstroem suas identidades, elaboram novas formas de relacionamentos, escondem-se e se expõem publicamente, deixam o espaço assim que motivados a fazê-lo, motivo pelo qual Gee (op. cit.) não usa termos como membros, comunidade. Diferente de uma comunidade, os participantes têm, em princípio, mais flexibilidade. Por exemplo, eles compartilham interesses, objetivos, práticas não em termos de raça, gênero, idade, classe 
social. No Webnarah, eles participam com um nome por eles criado, conferem informações "verídicas", enfim, interagem a partir de um avatar. Caso o leitor tenha interesse em observar o refeido site, basta acessar http://www.webnarah.pro.br/old e se cadastrar mediante uma senha com seis caracteres, um login e seguir as instruções dadas ${ }^{17}$. O portal do referido site acolhe participantes com conhecimento de mundo diversificado. $\mathrm{O}$ elo que os mantêm num perfil universitário, entretanto, traz depoimentos afins, como veremos em futuros capítulos (trabalho e vida estudantil, época de provas na faculdade). Uma outra característica do espaço de afinidade é a riqueza de troca de conhecimentos e experiências entre os participantes. No Webnarah, por exemplo, um dos hiperleitores sugere que os outros leiam Milton Santos para distinguir informação de conhecimento. A esse tipo de conhecimento, Gee (2004) denomina conhecimento distribuído, ou seja, conhecimento que advém do locus de enunciação dos participantes e que pode “contagiar”' outros ou que pode ser partilhado entre eles.

O mesmo autor também chama a atenção ao que denomina conhecimento disperso, ao se referir ao conhecimento que o participante pode acessar a partir de outros sites ou espaços e representa um conceito observado na pesquisa focalizada. Os hiperlinks para vários temas como imagens, vídeo games, charges, em Webnarah, prestam-se ao encorajamento da exploração desse tipo de conhecimento. Além disso, o espaço de afinidade oferece múltiplas rotas para aprendizagem e ensino colaborativo, interdisciplinar. O hiperleitor escolhe o que debater, como e quando debater e pode sugerir novidades, oferecer sugestões, inclusive por ter conhecimento mais expandido e mais experiência acerca de um determinado assunto que a própria pesquisadora.

Fiada, assim, nessas premissas referentes a metodologia de pesquisa de cunho exploratório, procuro levar em consideração as perspectivas dos hiperleitores pesquisados e os efeitos que a composição do meio digital poderá suscitar. A característica principal desta investigação apóia-se na intersubjetividade dos pesquisados. A pesquisa de natureza exploratória poderá auxiliar na compreensão da complexidade das interações sociais, dos valores, das alteridades sócio-culturais, comportamentos verbais e não verbais, enfim, das interações digitais.

\footnotetext{
${ }^{17}$ Caso o hiperleitor esqueça a senha e/ou login, uma propaganda de pendrives aparecerá na tela como sinal de que é preciso acessar o site sempre com a mesma senha e o mesmo login do cadastro.
} 
Para fins de registros de dados, foram previstas: 1) minhas constantes visitas a Webnarah para ler, interagir e imprimir ideias consideradas significativas à investigação; 2) entrevistas online com o grupo todo; 3) entrevistas presenciais com alguns hiperleitores. Penso que atentar para situações inusitadas e, portanto, contingentes, pode revelar formas de produção de conhecimento.

A natureza exploratória desta pesquisa reserva à pesquisadora a oportunidade para encerrar a interação a qualquer tempo, ou seja, em princípio não houve prazos definidos para o término da coleta de dados. O que confere sustentação a esta pesquisa é o fato de que sua natureza exploratória (Gee, 2004: 77-90) está acima da mera descrição analítica dos dados. Quando novas linguagens surgem, torna-se sumamente importante que novas metodologias sejam adotadas e exploradas numa tentativa de dar conta da complexidade das transformações culturais, conforme acredita a orientadora desta pesquisa. Assim sendo, a proposta, aqui, se caracteriza por um espaço não monolítico em que a complexidade de diferentes identificações, experiências e saber se articulam num meio digital que é comum a todos os participantes daquele determinado grupo, pelo menos à primeira vista. A metodologia em questão permite aberturas para usos de certos prefixos como multi, pluri, inter, trans, sem que um apague os conflitos historicamente gerados por terminologias antecessoras, apenas os transforma de acordo com as novas concepções que são lançadas pelas teorias e pelas novas práticas. Na era digital, a linearidade e as lutas ideológicas prosseguem, porém, há que se reconhecer existir nelas uma interação de hiperleitores, cujos interesses, gostos, curiosidades, estratégias, cognições estão minimamente ligados num campo de afinidades, passíveis de mudanças, ou seja, de discórdias e contestações das opiniões alheias.

Castells (2006: 444-446) evoca os efeitos colaterais desse espaço como sendo uma comunidade real e virtual, porém não como comunidade física, pois, as dinâmicas que a regem são específicas. Os hiperleitores que ingressam em tal comunidade, criam perfis e afiliações com interesses multidimensionais, muitas vezes ampliam o âmbito de solidariedade, sociabilidade, bem como a morte instantânea de laços por meio de um comentário infeliz, por exemplo. Vivemos uma era cosmopolita, de pós-identificação em que é possível indagarmos se precisamos, de fato, participar de uma comunidade, na acepção restrita do termo, quando há resíduos culturais que nos interligam e nos transformam. Isso compõe uma rede virtual em processo em que uma narrativa leva a outras e outras, sem serem reduzidas ao conteúdo 
estruturante do ensino convencional. A maneira em que estas são contadas também se constitui em nossa identificação.

Dessa forma, observo os comentários dos hiperleitores a respeito de um determinado assunto, ao mesmo tempo em que eles me observam. Em certos momentos não resisto à tentação de participar e, confesso que acabo por guiá-los, vez por outra, aos pontos de vista ideológicointerpretativos que idealizava. No fundo, tenho consciência dessa interferência. Nem por isso, os debates surtem os efeitos desejados, segundo as minhas expectativas, às vezes, positivistas, por assim dizer. A título de ilustração, momentos como eleições para Presidente 2006 (que relacionei por ser um tema daquele momento e imaginar que os universitários estariam engajados), não chegam a caracterizar uma polêmica que incentive a participação de todos os que haviam se cadastrado em Webnarah. Dos trinta voluntários cadastrados, apenas quinze expressaram opiniões, pelo menos uma vez, durante todo o período da investigação.

Outras características foram observadas quanto a minha participação no processo, por exemplo, tomar iniciativas na última hora, de fato não constitui parte de meu perfil. Por essa razão, não tardou para que as dificuldades mais marcantes emergissem: a escassez de material que eu vinha selecionando, antecipadamente; o tempo para pinçar outros materiais que julgava oportunos, ao menos da minha perspectiva, para promover discussões; estabelecer hiper(links) - via de acesso direto ao texto alvo - dentro de Webnarah, visto que nem sempre a página alvo encontrava-se disponível à transposição (ex.: nem todas as charges encontram-se em formato adequado para relocações); tempo hábil para assistir aos filmes e peças em cartaz, exercício que ativa a intertextualidade; lidar com a própria ansiedade no sentido de torcer para que os participantes tivessem assistido aos mesmos filmes; respeitar o rítmo, estilo, gosto, interesse, habilidade, recursos técnicos de cada um deles, pois sabemos que todos estavam muito ocupados com as tessituras prioritárias da vida (emprego, provas na universidade), mormente em se tratando de voluntários para pesquisas.

Tudo isso concorre para que Webnarah se caracterize por marcas próprias, acadêmicas e não como um site tipicamente profissional, com as atrações e riquezas de recursos multimodais. Ao invés, o site adquire perfil artesanal, o que fora previsto desde o início. A pesquisadora, desprovida de curso e treinamento técnicos prévios, prossegue colhendo os frutos, conforme 
as contingências. Faço um inventário de algumas das habilidades que me foram necessárias desenvolver. Dentre elas destacam-se: 1) pesquisar imagens e materiais online julgados relevantes e ricos para incitar debates, pelo menos de uma certa perspectiva; 2) transferir, transpor imagens (em formato JPG) e conteúdo de links, hiperlinks (charges animadas, músicas, demonstrações de vídeo games) para as categorias de Webnarah; 3) inserir imagens e textos no home; 4) realizar download de recursos mediadores como limewire ${ }^{18}$; 5) alterar e adicionar instruções para cada categoria; 6) cadastrar os hiperleitores que apresentavam dificuldade para fazer seus cadastramentos; 7) gerenciar e tabular o número de participantes para cada categoria e enquete, como curiosidade e conferência de logins e respectivos e-mails para eventual contato, e não como metodologia puramente quantitativa; 8) criar grupos de hiperleitores em webmail; 9) enviar mensagens com anexos de conteúdo de e-mails para debates, com cópia oculta para os participantes.

Aos hiperleitores deixei explícito que as regras compreenderiam basicamente: mediante o endereço de Webnarah, fazer o auto-cadastramento com senha e login (apelido, nome fictício) de preferência que escondesse o nome real; ser universitário, escolher pelo menos cinco categorias semanais para debatê-las com outros participantes; sugerir materiais para debates no referido site.

Aparentemente o perfil de um total de quinze que, definitivamente, se aventuraram por esta experiência de pesquisados não denotou falta de familiaridade para com os recursos tecnológicos e navegação em web. Muito ao contrário, houve momentos em que a minha aprendizagem fora suscitada por demonstrações de mais experiência relacionada, por exemplo, aos video games por parte de certos hiperleitores.

No que tange às fontes de dados, elas foram geradas mediante a observação contínua dos hiperleitores em Webnarah; trocas eletrônicas (mensagens de e-mails, ora entre pesquisadora e hiperleitor, ora entre pesquisadora e pequenos grupos, com cópia oculta, ora entre pesquisadora e Gustavo); anotações periódicas realizadas pela pesquisadora como excertos relevantes para futuras análises e reformulações de instruções.

\footnotetext{
${ }^{18}$ Programa que permite ao hiperleitor fazer download de músicas, sem nenhum custo.
} 
A escolha das categorias, das imagens, dos temas em geral seguiu o conceito de narrativa desenvolvido por Bruner (1986:11-51 e 2001: 127-143) segundo o qual, todo evento é somente possível de ser relatado e interpretado através da linguagem, tendo, necessariamente, que passar pelo crivo do repertório cultural do intérprete. É justamente a natureza polissêmica da linguagem que permite a seu articulador, no caso desta pesquisa o hiperleitor, evocar múltiplas perspectivas e construir sentidos a tudo que o circunscreve.

Com efeito, o pensamento torna-se inextricável da linguagem. Povoamos nosso universo de participação com personagens, acontecimentos, sonhos, de forma íntima e social. Atribuímos significados a eles, motivados por nossas crenças, desejos, valores, princípios teóricos e experiências, num contínuo esforço para torná-los novamente reinterpretáveis e ao mesmo tempo, mantendo considerável dose de cumplicidade com os resquícios do contexto sóciohistórico no e do qual interagimos. Esse conceito prevê construções sócio-ideológicas no ato da interpretação, as quais mesclam produção e recepção de sentidos, diluindo, em decorrência, a fronteira entre autor e hiperleitor e ao mesmo tempo, reforça a impossibilidade de se produzir a “realidade”, gerando apenas renegociação de verossimilhanças.

Para a concepção de Webnarah, utilizei, como critério das seleções de materiais, as influências que recebi de Manovich (2001). Este capta com invulgar acuidade o fato de que imagens, animações, enfim, a linguagem multimodal, fomenta a “nova” mídia, ou seja, a digitalizada, sem deixar de ser mass media. Tudo isso vem modificando epistemologias de conhecimento e de agência humanas, dentro e fora das escolas e das instituições em geral.

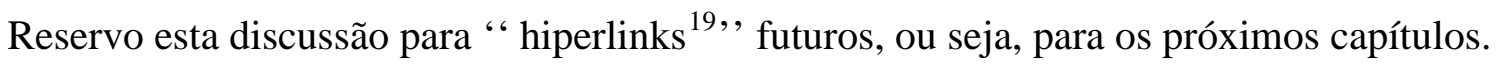

Como veremos mais adiante, as categorias servem como oportunidades para apresentar as perspectivas dos voluntários, demonstrando conhecimento de mundo, influências de suas práticas sociais, aprendizagens e experiências gerais, independente de qualquer concepção que explique o que é ser um novato, letrado, perito, no espaço digital. Essas interações on-line

\footnotetext{
${ }^{19}$ No ambiente da Web, hiperlink corresponde a uma área constituída por imagens ou palavras, sublinhadas e grafadas com uma cor diferente daquela restante do texto. Quando o mouse pousa sobre o link/conexão, o ponteiro assume a forma de uma pequena mão com o dedo indicador esticado. Ao ser clicado, um link redireciona o hiperleitor para outra página ou para outro local dentro da mesma página.
} 
se apresentam com mais propriedade ainda, por comparecerem com um viés marcado por diferenciados usos e interpretações influenciados, quando não formatados, por diversas histórias, culturas, ideologias, economias e, por conseguinte, relações de poder. Nas análises dos textos mantive as falas dos hiperleitores sem proceder a qualquer tipo de correção gramatical e utilizei os mesmos excertos de interações em diferentes momentos de apresentação, análise e interpretação.

Realço, no entanto, o potencial da natureza mutante do conjunto de forças acima referido, o qual, constantemente, se digladia na relação micro (intersubjetividade do intérprete) e macro (contexto maior da aparente desordem mundial).

Como o leitor já deve ter percebido, lidar com a questão de letramentos críticos implica estudos sobre a produção e hermenêutica na concepção de Ricoeur (op. cit.) no meio eletrônico-digital, e que, sendo os letramentos na forma pluralizada, revelam, para muitos críticos seus limites e méritos. Percebe-se que muitos autores demonstram um grande entusiasmo pelas propostas de “"novos” letramentos. Já para os principiantes nestes estudos, observa-se que a emergência das novidades pode provocar um certo reverenciamento justamente pelo desejo de se mostrar atualizado com as inovações. Entretanto, essa premissa não se aplica ao meu posicionamento, pois, baseando-me no citado autor, parto do princípio de que deve sempre haver uma suspeita de leituras já consagradas em relação ao paradigma digital, que traz à baila uma profusão de imagens, sons e animações, como possibilidades de produção de sentidos em meio a uma rede complexa de poder. Como ilustração do que vem acontecendo em muitos ambientes fora das escolas, discorro a respeito dos jogos eletrônicos e suas impliações na educação.

\section{Educação, “novos” letramentos: para ilustrar, os vídeo games}

Quando se fala em novos letramentos, nasmudnças epistemológicas na educação, os vídeo games possbilitam boa compreensão sobre as transformações que a linguagem tecnológica 
traz para a sociedade. O rápido e incalculável impacto que os vídeo games têm causado nos momentos de entretenimento, e que, agora, estão atrelados à aprendizagem, de acordo com expectativas e comprovações experimentais de Gee (2003), tanto em jovens como em adultos, têm estimulado pesquisas mais sistemáticas a respeito dos possíveis efeitos na educação. Há uma vertente de grupos que não simpatiza com a adesão aos usos eletrônicos por recearem que a violência se prolifera a partir de muitas fontes, incluindo a dos vídeo games. Logo, para educadores seria interessante abandonar eventuais raciocínios apressados que condenam qualquer tipo de vídeo game e, assim, favorecer a uma indagação sobre o que tal conteúdo pode provocar em cada hiperleitor no que diz respeito ao desenvolvimento social, cognitivo, físico e emocional do aprendiz.

Não à toa, muitas famílias têm dado as boas vindas ao consumo de eletrônicos, como agendas eletrônicas, telefones celulares, computadores, cada membro assistindo ou articulando com uma determinada tela digital no mesmo lar, simultaneamente. Essa prática social possibilita estudar as implicações ideológicas de quem escolhe o jogo, suas estratégias, quem monitora e qual é a apreciação crítica que cada jogador traz e desenvolve ao interagir com um determinado jogo. Constata-se que há mudanças ocorrendo no âmbito familiar, nas Lan houses $^{20}$ devido aos efeitos das telas virtuais. A experiência virtual tem gerado diferentes implicações, dependendo das especificidades contextuais nas quais o hiperleitor, o professor, a instituição educacional se inserem.

O atual pano de fundo que transpassa tais jogos os quais poderão fornecer matéria-prima sócio-cultural, concebida como processo de construção de sentido, aos educadores culturais advém de questões relativas a: gênero, estereótipos, violência, consumismo, relação virtualreal, letramento crítico, afinal, mais do que nunca, navegar é e não é preciso, conforme sugere parte do título da presente tese. Isso tem consequências nas elaborações de currículos escolares, na questão de cidadania.

\footnotetext{
${ }^{20}$ LAN: Local Area Network. Lan house refere-se a uma loja que aluga máquinas, interligadas em rede, por meio das quais os usuários acessam jogos, à Internet e outras utilizações afins.
} 
Em sua clássica obra, $O$ que os video games têm a nos ensinar sobre aprendizagem $e$ letramento $^{21}$, Gee (op. cit.) insinua que uma espécie de seleção natural poderá ocorrer, se não tivermos a preocupação de compreender como a cultura de jogos digitais que tem surgido em nossa sociedade, neste novo milênio, pode beneficiar jovens e usuários de todas as idades.

O tratamento que o referido autor confere aos estudos de vídeo games nutre-se da ideia de que a interação (altamente performativa) do jogador com a máquina constitui-se num complexo processo de aprendizagem em que estratégias, tomadas de decisão com a mente em rede, ressaltada por Castells (op. cit.), habilidades técnicas passam a ser predominantemente contingenciais.

Vale a pena apontar resultados de certas pesquisas realizadas a respeito de jogos e suas implicações na educação. Pesquisadores como Sanger, Willson, Davies e Whittaker (1997) procederam a uma pesquisa de dois anos, a partir de 1997, com crianças de quatro a nove anos, operando vídeos e jogos de computador. Eles entrevistaram pais de diferentes composições nucleares, aprendizes e professores, gravaram e filmaram entrevistas tanto nos lares, como nas escolas que tais crianças frequentavam. As conclusões parciais revelaram que: a maioria de pais demonstram atitude laissez-faire por conta do status que os filhos adquirem diante dos colegas por terem hardware e software; eles reconhecem os benefícios e medos da máquina, porém, não possuem conhecimento e prática aprofundada para atuarem como mediadores entre consumo, experiência e aprendizagem crítica; medo de que as crianças os excluam por desenvolverem códigos (por exemplo, :-; indica sorriso) e jargões próprios do meio digital e medo de que a escrita convencional acabe sendo esquecida; falta de conhecimento acerca dos conteúdos de revistas, vídeos e jogos por parte dos pais e seus possíveis efeitos na formação educacional dos filhos, conduzindo à crença de que a aprendizagem ocorre por osmose, no dizer dos autores acima citados; estereótipo de gêneros reforçado pelo conteúdo de certos jogos e pela própria atitude de certas mulheres que repassam problemas de ordem técnica que requerem habilidade técnica, aos maridos; mães solteiras que, por outro lado, demonstram maior auto-confiança ao interagir com a tecnologia; professoras que discriminam e criticam vídeo games unilateralmente por acreditarem que incitam apenas à sexualidade e atos violentos em sala de aula e escondem a

\footnotetext{
${ }^{21}$ Traduzo o título original: What video games have to teach us about learning and literacy.
} 
falta de pré-disposição para se letrarem por trás desse argumento; paradoxo na medida em que a literatura infantil já ilustra fantasmas, mortes e bruxarias nos livros que penetram a sala de aula; meninas que recorrem mais facilmente às professoras, ao passo que os garotos insistem em buscar soluções autonomamente; garotos que demonstram melhor manuseio de joy sticks e meninas que preferem mouse e keyboard; os garotos apreciam competições e desafios para obter altas pontuações, enquanto que as meninas pensam que os video games são perda de tempo; garotas que desenharam jogos ideais com ênfase em narrativas e detalhes e garotos que centraram em ações e temas referentes à morte; garoto considerado tímido que ganhou respeito e status de expert da sala; crianças de classe social média tendem a olhar para os jogos com uma certa moral ortodoxa.

Além do exposto, Sanger \& Willson, Davies, Whittaker (op. cit.: 97) afirmam que poucos adultos têm consciência e preocupação no que tange às consequências da prática de video games, a despeito da introdução de utilização de vídeo em instituições educacionais por volta de 1972. Parafraseando-os, este entretenimento através da tela digital como parte da interação doméstica com a cultura “popular”' vem estreitando as fronteiras entre fato e ficção.

Indo ao encontro de expectativas de benefícios dos video games, Cassell e Jenkins (2000) também realçam o fato de que os jogos assumem uma gama imensurável de significados e efeitos de sentidos. Tal como a arte, neles figuram um verdadeiro manifesto estético e ideológico em que a “libertação”, do ser depende dele próprio, por assim dizer. A partir de sua co-autoria, mecanismos ideológicos e fatores manipuladores de senso crítico, novas possibilidades de interpretação e agência se abrem, tal como um complexo playground, embora muitas vezes o espaço virtual tenha sido caracterizado pela reprodução de culturas.

A cultura dos video games carrega resquícios das diferentes formas de agressão as quais constituíam e constituem facetas identitárias dos homens. Segundo Rotundo (op. cit: 279), a hiper masculinidade se revela nas promoções de interações ativas em que autonomia, autoconfiança, habilidade de comando e auto-controle são convocados para que os garotos estabeleçam objetivos a serem alcançados e a disciplina com a qual lidarão com os desafios. Longas horas de treino, de repetição, de falhas, de exaustão física ou emocional configuram o combate, a violência simbólica. É simbólica, na medida em que isso representa uma 
transgressão aos ditames e intervenções parentais, fazendo com que o garoto se afaste das instruções e figuras maternas. Tal manifestação sutil e indireta se projeta em personagensprotagonistas de jogos como Super Metroid (op. cit: 273) em que os vencedores são premiados com um semi-strip tease de personagens femininas. Outras vezes, em outros jogos, os jovens testam as ideologias dos adultos, desenvolvem um senso de suas próprias identidades e habilidades, ferramentas necessárias ao gerenciamento do jogo.

A lista, a seguir, mostra as possibilidades do que se pode explorar quanto à aprendizagem em currículos “domésticos””: História americana: Revolution ou Sid Meyer’s Gettysbury; História antiga: Age of empires; Animais: Zoo Tycoon; Biologia e evolução: Spore; Química: Chemicus; Chinês: versão chinesa de seu jogo favorito; Ecologia: Sim Earth; Inglês: Scrabble, Bookworm; História do oriente: Eyewitness; Francês: versão francesa de seu jogo favorito; Japonês: versão japonesa de seu jogo favorito; Matemática: mini jogos disponíveis em Google; Mecânica: The incredible machine; Física: Super monkey ball; Leitura: Yu-Gi-Oh; Robótica: Mind rover.

Evidencia-se, assim, uma sociedade com novas atividades sociais, com realidades complexas e um dos meios mais fluidos em que tais interações podem ocorrer é o meio eletrônico-digital. Nesta pesquisa, de certa forma, procurei ver os reflexos de teorias que li nos hiperleitores que investiguei. Algumas nuanças se fizeram perceptíveis. No entanto, os pesquisados se mostraram mais como “outsiders” do que “insiders”, reforçando as asserções de Lankshear e Knobel (op. cit.). Tais autores vêem diferenças de interação com o mundo digital entre as gerações anteriores à década de 90 (“outsiders”) e as posteriores a esta (“insiders”). Entendem que os insiders têm maior familiaridade e facilidade com o universo digital, por já terem nascidos numa sociedade amplamente tecnológica. Fundamental para a tese de que o espaço digital vem favorecendo novas construções de conhecimento é a compreensão e interpretação de certas teorias que cuido de explicá-las no próximo capítulo. 


\section{Capítulo 1}

\section{Os “novos" letramentos e o hiperleitor}

Estudiosos da educação e quiçá de muitas áreas de conhecimento, mais do que nunca, se preocupam em buscar novas epistemologias e formas de agenciar as contingências. Sem dar a última palavra, Lankshear e Knobel (2005) enfocam o letramento digital como forma de sobreviver às perigosas tentativas de colonização e europeização das sociedades ditas minorias, via novas tecnologias. Dessa forma, vale discorrer a respeito de um breve histórico para melhor situarmos os letramentos e suas transformações.

A história do letramento adquire mais teor nas décadas de 50 e 60 quando o teórico Anderson (In: op. cit.: 4) postulava que o referido termo associava-se automaticamente à disposição que um país em ascensão apresentava para as guinadas econômicas. No chamado terceiro mundo, praticamente $80 \%$ da população adulta eram consideradas analfabetas e desprovidas de qualquer ensino formal que pudesse alavancar suas condições de trabalho e vida ao progresso, visto como cívico. Assim, o analfabetismo gerou campanhas com a finalidade de atender principalmente aos adultos, por meio de programas informais de alfabetização, visando à leitura de textos impressos de suas vidas diárias.

Decorrente dos receios de comunismo no pós-guerra (aproximadamente entre 1950 e 1960), e em função do rápido e ameaçador avanço tecnológico (rádio e televisão), as escolas se viram diante da necessidade de desenvolverem habilidades de leitura para prepararem as crianças para o mundo complexo que se despontava na época. Sob fortes influências da tradição neoliberal, emergiu a chamada leitura crítica que, segundo Cervetti, Pardales, Damico (2001), enfocava principalmente: a decodificação de sentidos pelos leitores; a busca pelas intenções do autor através de lentes racionais; linguagem objetiva conectada a uma realidade ordenada e transparente; criticidade e habilidade para distinguir opinião de fato; suspensão de julgamentos até que evidências textuais fossem detectadas; avaliação sobre o que seria arbitrário, preconceituoso e neutro; crença numa realidade concreta usada como referência interpretativa; crença na ideia de uma interpretação correta e uma errada. 
Uma outra perspectiva sobre “educação crítica”, surgiu com a identificação “letramento crítico’'. O letramento crítico, de acordo com os referidos autores, encontrou várias influências na sua formação. Uma delas adveio da teoria crítica social, no tocante a aspectos como: alívio do sofrimento dos oprimidos; crítica aos problemas sócio-políticos; alternativas para uma sociedade mais justa. Uma segunda influência ao letramento crítico surgiu na década de 70, com o pensamento de Freire (Lankshear, Knobel, 2005). A concepção de letramento adquiriu, assim, uma nova característica com as contribuições desses autores.

O trabalho de Freire com camponeses brasileiros e chilenos indicava a necessidade urgente de lidar com o letramento a partir de um viés e prática sócio-crítica, ou seja, ler o mundo ultrapassando a mera decodificação das palavras. Nasceu daí um esforço coletivo que apontava para processos mais reflexivos e ações na prática, que possibilitassem a análise e compreensão da realidade injusta em que os leitores se inseriam, no afã de aprender a ler e escrever de maneira minimamente historicizada. As novas dimensões econômica, cultural e social, alertavam os leitores às construções de sentido contextualizadas, para então se prepararem e engajarem numa ação cultural para desafiar, resistir e subverter relações sociais que beneficiavam alguns grupos em detrimento de outros, incluindo eles próprios.

Uma vez estudado os resultados de uma primeira ação coletiva, os camponeses deveriam proceder a outras iniciativas, isto é, prepararem-se para atender as necessidades daquela sociedade em transformação. Donde: ação e reflexão compõem o projeto pedagógico de Freire (op. cit.:6). Uma segunda influência que o letramento recebeu deveu-se à era pósindustrial americana, bem como às novas necessidades de mercado na Inglaterra, Canadá, Austrália e Nova Zelândia. As escolas, nesses países, enfrentavam uma crise avassaladora na educação, sem que pudessem formar cidadãos minimamente críticos, associados à qualificação para os “novos trabalhos” que emergiam na ocasião, conforme postulam Muspratt, Luke, Freebody (1997). Segundo esses autores, no século 19 e final do 20, a educação de letramento limitava-se a reconhecer palavras, práticas ortográficas, leitura em voz alta, exposição à literatura clássica. Tal critério de conteúdo acabou por classificar quem era diaspórico, exótico, oriental em relação ao centro cultural europeu. A referência prática de leitura acabou reproduzindo, assim, a legitimação do poder desse centro. Para ilustrar melhor as mudanças de foco entre leitura crítica e letramento crítico, apresento a tabela proposta por Cervetti, Pardales, Damico (2001:9): 
Área

Conhecimento

(epistemologia)

Autoria

Objetivos instrucionais

\section{Leitura crítica}

O conhecimento é adquirido através de experiência sensorial no mundo e através do pensamento racional; uma distinção entre fatos, inferências e julgamentos do leitor é concebida.

\section{Letramento crítico}

O que conta como conhecimento não é natural ou neutro; o conhecimento é sempre baseado em regras discursivas de uma determinada comunidade, e é, portanto, ideológico.
A realidade é diretamente acessível e pode, portanto, servir como um referente para interpretação.

Detectar as intenções do autor constitui-se como base para níveis superiores de interpretação.

\footnotetext{
Desenvolvimento de habilidades de alto nível de compreensão e interpretação.
}

A realidade definitivamente não pode ser conhecida e não pode ser captada pela linguagem; decisões sobre verdade, portanto, não podem ser baseadas numa teoria de correspondência com a realidade, devendo estas, serem construídas localmente.

O significado textual é sempre múltiplo, contestado, historicamente situado e construído em meio a diferentes relações de cultura e poder.

Desenvolvimento de consciência crítica.

Tabela 1. Orientações Curriculares para o Ensino Médio: Línguas Estrangeiras. ${ }^{22}$

Bem examinada as nuanças, merece destacar que o letramento crítico prima por uma abordagem que considera o processo de leitura como uma construção de significados atrelados ao contexto sócio-histórico, político e econômico, às relações de poder como uma forma de vir a conhecer o mundo, vir a conhecer a si mesmo, conforme nos ensina Ricoeur (op. cit.). Vale dizer, vir a transformar a si mesmo. Perguntas como: Esse texto dissemina interesses de quem, de que grupo social? Que interesses não são atendidos? Que outras visões de mundo são possíveis? Nesse processo, o leitor atribui sentidos ao texto, questionando seus estereótipos e forças ideológicas com o exercício da hermenêutica da suspeita, teoria a ser abordada mais adiante, que possibilitará a transformação de grupos marginalizados e, portanto, menor desigualdade social.

\footnotetext{
22 Tabela original, em inglês, no site http:www.readingonline.org/articles/cervetti/.
} 
Assim, a partir das décadas de 80 e 90, o letramento emerge como sendo a chave para a educação formal, trazendo a perspectiva sócio-lingüística nos estudos da linguagem, gerando a mudança de leitura e escrita para letramento. Dito de outra forma, este último torna-se uma questão de prática social atrelada às relações macro e micro da história; os textos constituemse em parte integrante das práticas que ocorrem em tempo-espaço específicos. Os leitores articulam textos diferentemente, em práticas sociais distintas, e tais maneiras diferentes de lidar com o texto, alteram não somente suas identificações, mas, também as ideologias e participações dos indivíduos na sociedade. Não se pode, assim, dissociar a leitura de outros componentes como: valores, gestos, interações com sons, imagens e animações, não importando em que meio estes ocorrerem.

Nessa esteira histórica, novas concepções teóricas sofisticaram o conceito e a prática de letramento para uma pluralidade que engloba: letramento cultural, crítico, técnico, tridimencional, de poder, ambiental, matemático, midiático, computacional, político, oral, visual, científico, emocional, enfim, multi-letramentos. Os letramentos tornaram-se uma indústria. Green (In: Muspratt, Luke, Freebody, 1997: 10) lança três dimensões igualmente essenciais e simultâneas: operacional, cultural e crítico. No nível operacional, os rudimentos da língua, os procedimentos e estratégias concorrem para a proficiência da língua: ler e escrever competentemente em diversos contextos da vida. A dimensão cultural, como sugerida pelo próprio nome, compreende a articulação com a prática social; entender e lidar com textos em relação contextual; como os textos apresentam maneiras particulares, mas, não únicas, de interpretação, sem se perder em meros relativismos. A dimensão crítica corresponderia à capacidade interpretativa para construir novas visões culturais que, aparentemente, se apresentam de forma velada em um determinado texto.

Reconheço a natureza “didática” da referida divisão, com diferentes focos e interpreto que todas essas dimensões se apresentam interligadas. E, ainda, que não há como fugir da permeabilidade da dimensão crítica no conjunto das três dimensões. Em todas as fases, está presente o elemento da criticidade, pois, é com esta criticidade que o leitor se socializa no e com o texto, ao perceber que este é sócio-ideologicamente construído e que, portanto, inclui alguns valores, ideologias, perspectivas, excluindo tantos outros. Essa dimensão abre espaço para o papel ativo do hiperleitor que transformará criticamente os significados de acordo com o seu conhecimento de mundo, sua bagagem cultural, habilidades técnicas e prática social de 
sua vida diária. Com essa consciência, teoricamente, o leitor, hiperleitor no caso desta pesquisa, estaria capacitado a promover rupturas e transformações reescrevendo a sua própria história. Essa se configura como uma herança de Freire, como detalhado anteriormente.

É então que, na era digital, Cope e Kalantziz (Apud Lankshear e Knobel, 2003: 11) pugnam por novas linguagens de tecnologia que acessem novas formas de trabalho, cidadania e práticas pessoais e/ou coletivas no cotidiano do ser humano. As referidas práticas, mais do que nunca, conferem visibilidade ao estudo das imagens, animações e em geral às interações textuais via máquina: computador. Portanto, resta aos educadores a tarefa de estender os ensinamentos de cunho técnico, já que know how para manipular e operar o sistema da língua não é suficiente, a ponto de desenvolver nos aprendizes a capacidade de negociar criticamente com as novas condições de trabalho e vida.

Ainda no final da década de 80 e início da de 90, Gee (op. cit.: 12) reforça o conceito de letramentos balizado na questão de discurso. Este como sendo maneiras de estar no mundo, abrangendo, portanto, palavras, atos, crenças, gestos, atitudes, propósitos, vestimentas, identificações, grupos sociais com posicionamentos dinâmicos frente à história. O discurso varia de grupo para grupo, de hiperleitor para hiperleitor, lembra o citado autor, reforçando a conhecida asserção de que não há hiperleitor desprovido de ideologias.

Para compreender e articular discursos de forma crítica é necessário que voltemos o olhar para um conjunto de meta-palavras, meta-valores, meta-crenças, isto é; usos singulares da linguagem que reconstróem nossas identificações e nos situam na sociedade; reconhecer discursos como discursos, significa dizer como eles articulam e promovem determinados valores; seria a capacidade inerente da linguagem permitir e viabilizar isto através do caráter permeável e maleável do signo linguístico. Munidos desse conhecimento, decidiremos por praticar um e não outro discurso, por alterá-lo dependendo das circunstâncias contextuais imediatas. A esse poder, Gee (op. cit.) define como sendo letramento de poder.

Pesquisadores como Street (1993) e o próprio Gee (1996), (In: op. cit.: 16) valorizam duas vertentes nos estudos de letramentos, a saber: vertente paradigmática e vertente ontológica. A 
primeira confere tratamento a partir de uma abordagem acentuadamente sócio-cultural ao passo que a segunda, enfoca as alterações causadas pelos efeitos eletrônicos na prática de leitura diária. Peritos da vertente paradigmática, Giroux (2005), Muspratt, Luke e Freebody (1997), Lemke (1998) ponderam que uma prática de leitura e interpretação, a começar pelos currículos escolares, deve conscientizar os cidadãos das ideologias dominantes, travestidas de senso comum e/ou canonicidade ${ }^{23}$ e promover uma mudança de foco em tais práticas de sorte a analisá-las sob a perspectiva sócio-cultural, considerando os conhecimentos e experiências que os cidadãos trazem para a sala de aula e, por extensão, os hiperleitores.

De acordo com pesquisas realizadas por Muspratt, Luke e Freebody (op. cit.: 200) os cidadãos de menor acesso aos novos letramentos coincidem com aqueles de menor participação ativa na esfera política e tais autores indagam se isso impera por conta desses cidadãos deterem menos poder por serem menos letrados criticamente, ou se são menos letrados por deterem menor poder. Não se trata de uma questão a ser resolvida aqui. Mais do que tentar responder a esta pergunta, os projetos sobre novos letramentos propõem que estes cidadãos andarilhos e vítimas das próprias escolas tenham uma prática pedagógica de leitura que rompa com: 1) os legados coloniais europeizantes; 2) com positivismos e binarismos centrados na rigidez de dominante e dominado; 3) com a crença do sujeito uno e passivo; 4) barreiras outras que os impeçam de promover mudanças coletivas no nível individual, contagiando assim as esferas públicas. Ao contrário, os educadores críticos deverão, criativamente, oferecer condições para que as diferentes epistemologias de conhecimento e poder sejam construídas, para que outras narrativas tornem o familiar novamente estranho, para perceberem o mesmo evento, texto, e saírem com narrativas diversas, porém, contextualizadas.

A vertente ontológica, por sua vez, parte das inovações na tecnologia, instituições, mídia, economia, finanças, comunicação, globalização, as quais causam mudanças bruscas nas práticas sociais: trabalho, lazer, família, educação, esfera pública em geral. Muitas dessas mudanças impulsionam maneiras de produzir textos eletrônicos, caracterizando diferentes formas de prática textual (pós-tipográfica, assunto que será tratado no capítulo 2). Incluem-se nessa mira, o uso de hiperlinks entre documentos, imagens, sons, filmes, linguagem semiótica

\footnotetext{
${ }^{23}$ Diz-se da canonicidade, leituras que são aceitas, honradas e utilizadas por determinados grupos sociais, detentores de capital simbólico aparentemente hegemônico.
} 
pelo uso do mouse, leitura de arquivos complexos, identificação de que software fará a leitura de cada arquivo. Textos não lineares navegam, em profusão, em mundos online, tridimencionais, clamando por uma prática de leitura especializada.

As habilidades pressupõem uma prática, pois, dificilmente um hiperleitor se engajaria em práticas sociais paras as quais não tivesse sido exposto, socializado. Não há como fugir da cumplicidade para com os diversos valores sociais, acreditando que novas ciências, meramente tecnicistas, minimizarão as desigualdades sociais. Isso não quer dizer, no entanto, que estamos num dilema, num beco sem saída, estamos tentando reaprender, cuidando para que experiências locais não se tornem universais.

Centrados na perspectiva de que há uma escassez de estudos de leitura no âmbito do discurso oficial do letramento crítico, Baker e Luke (1991:xix), sugerem um empreendimento educacional que tenha maior responsabilidade social no tratamento da leitura. Essa responsabilidade, conquanto suscite interesse, é, no entanto, altamente complexa. Requer preparo para ampliar as perspectivas históricas acerca do objeto de leitura e luta, coletiva, para fragilizar as consolidadas interpretações de grupos, considerados hegemônicos, as quais respondem, em proporções espantosas, pelas reproduções de hierarquia social por meio da própria educação em que as leituras priorizam a visão ocidental de mundo, corroborando os estudos de Lankshear e Knobel (2005). A questão vai além: muitas escolas acabam reproduzindo tais perspectivas, seja pela força midiática, por meio da qual tais leituras são veiculadas, seja pela falta de preparo do professor, dos aprendizes, da instituição, seja pela comodidade dos mesmos e interesses de foro pessoal e político.

Relembro o leitor que um dos maiores desafios da atualidade constitui-se em lidar com as contradições inerentes à co-construção de conhecimento aliado à prática social que ressurge, a (re)começar pelos novos meios eletrônicos de comunicação. Estes se apresentam como espaços oportunos para o que Lankshear e Knobel (op. cit.) denominam de novos letramentos, ou seja, leitura como uma prática social, portanto, envolvendo questões de cultura, poder, contestações das ideologias ditas hegemônicas, negociações discursivas e ações frente a essa problemática. 
Observa-se que o universo eletrônico-digital apresenta um vasto espectro de híbridas, múltiplas e fluidas identificações, no qual proliferam vários loci de enunciação, conceito de Bhabha (1997). Parafraseando Menezes de Souza (2004), o locus de enunciação, é o local atravessado por ideologias e valores linguístico-culturais, os quais se apresentam de maneira contraditória, ambígua, híbrida. Em outras palavras, o locus se refere ao contexto sócioideológico, cultural, altamente produtivo, no qual o usuário da linguagem se insere. Não se trata, pois, de casos reduzidos à idéia automática de que: aqui há uma cultura e, portanto, aqui há um letramento (here's a culture, here's a literacy, in: op. cit). As especificidades contextuais podem mostrar resistências variadas ao processo de transformação cultural. Assim sendo, torna-se mais delicado o trabalho lá desenvolvido, por mais preparado e cuidadoso que seja o cidadão hiperleitor e as instituições, nesse empreendimento em conjunto. Resta, pois, partirmos da conscientização de que não há uma origem cristalizada, a partir da qual congelamos verdades, mas, sim, interações sociais em que os efeitos de sentidos ali produzidos fornecem escopo para outros significados futuros, ambivalentes, efêmeros, essencialmente tradutórios e, portanto, passíveis de interpretações, de re-historicização.

O respeito às diferenças culturais requer o direito às mesmas tanto na esfera individual, local, regional, nacional e também no mundo digital, ao menos em teoria. Constituiu proposta desta pesquisa investigar os letramentos de uma comunidade de estudantes universitários enquanto debatem temas variados, apresentados em diferentes categorias, como por exemplo: vídeo games, charges, filmes, imagens, num site criado especificamente com finalidade de pesquisa. Analiso como tais hiperleitores narram suas experiências e conhecimento sugerindo, talvez, em seus imaginários, novos valores e posicionamentos políticos, possibilidades de coexistência (pertencer e não pertencer ao mesmo tempo a uma dada perspectiva transcultural) e de constante exercício hermenêutico (Ricoeur, 1978), consoante esclarecido anteriormente. Em outras palavras, como o $E u$ dos hiperleitores se reorganiza frente às mudanças do Outro e vice-versa, quem são eles e como se relacionam com o mundo digital no qual estão imersos. A perspectiva crítica que aqui adoto corrobora os postulados de Cervetti, Pardales e Damico (2001), para quem a construçao de sentidos pressupõe a influência das convenções e valores específicos da comunidade da qual pertence o leitor e que, portanto, o conhecimento é sempre situado e sujeito às mudanças histórico-culturais. 
Sabe-se, ainda, que muitos currículos universitários incluem reformas reconhecendo o direito às diferentes especificidades de patrimônios culturais, estes normalmente circunscritos à lógica do universo cultural etnocêntrico, mas que, agora, no meio eletrônico-digital, como a Internet, rompem com as fronteiras rígidas das identificações humanas, alargando o espaço para revisão de questões de epistemologia, poder (co-autoria, consumidor-produtor) e agência.

Estudos que enfoquem uma educação orientada para uma das formas de letramentos, letramento digital, tornam-se cada vez mais importantes na sociedade. Essa evidência justifica o meu projeto que busca conciliar as novas teorias que constituem tema central deste trabalho, com outros conhecimentos já desenvolvidos, como forma de contribuir para a área da educação universitária.

A análise dos dados de coleta demanda uma relação dialógica com a concepção de hermenêutica da suspeita de Ricoeur (op. cit.), visto como uma prática reflexiva e ética de auto-conhecimento, na medida em que expande a capacidade crítico-interpretativa. Ainda, Hall, em uma entrevista conduzida por Morley (In Morley, 1996: 393), nos ensina que é preciso constantemente tentar re-situar, traduzir as teorias - através da linguagem multimodal, complementaria o autor - sem contar com uma fonte original, a partir da qual a transculturação será processada, e, sequer lançar a última palavra/fonte.

Identifico que deve haver, nesse sentido, o que aqui denomino de permeabilidade contingente teórica, noção que abstraí e criei a partir das intertextualidades em minhas leituras. Explico: essa noção refere-se à capacidade inerente que certas teorias possuem de se inter-intra-transrelacionarem, de forma a reconhecer os conflitos e contradições que cada teoria postula, tendo em mente que devem se abrir para constantes interpretações e reflexões.

Interpreto as diferentes vozes e olhares dos hiperleitores, sujeitos desta pesquisa, que se abrem para novas questões e negociações no contexto de mundo digital; como tudo isso se articula nas próprias tensões e contradições, fazendo desse terreno antagônico, local de novas produções culturais, em novas condições históricas. Para tanto, recorrerei a teorias, conforme apresento a seguir, as quais julgo sine qua non para a compreensão da presente pesquisa. 


\subsection{Sobre os “novos” letramentos}

De acordo com Lankhsear \& Knobel (2005), o letramento não constitui um fim em si. Desenvolvê-lo significa ultrapassar a mera atribuição de sentido ao texto estudado, de forma a capacitar o leitor a participar ativamente no complexo social no qual ele interage. $\mathrm{O}$ letramento procura conscientizar o leitor de que os textos são produzidos, distribuídos e interpretados de acordo com objetivos, práticas, interesses sócio-econômicos e culturais que concorrem para serem legitimados e mantidos. Tais interesses não são uniformes para todos os cidadãos, motivo que torna mais complexa a articulação do letramento em meio a uma variedade e simultaneidade de necessidades e interesses interconectados: individuais, coletivos, nacionais, transnacionais, globais.

Para os mesmos autores, os novos letramentos associados com as mudanças contemporâneas em nossas instituições e economia não envolvem necessariamente o uso de TCIs (Tecnologias de comunicação e informação) ${ }^{24}$ ou seja, o uso de novas tecnologias. Para ambos, compreender os novos letramentos significa investigar o "velho" com novas lentes e, portanto, novas formas de pensar. Como exemplos ilustrativos de categorias que embasam essa abordagem, tais autores mencionam a construção de cenário e os zines. O primeiro se refere às narrativas que descrevem e procuram ensaiar alternativas baseadas em hipóteses e assunções plausíveis para pensar o futuro. Não são previsões, mas, sim uma preparação que tem por objetivo expandir o pensamento, estratégias, tomadas de decisão para futuras necessidades. Na educação, isso corresponde às elaborações de cursos de capacitação, de reflexão sobre, por exemplo, questões de ensino e aprendizagem de letramento e tecnologia para um determinado grupo de aprendizes e seus possíveis significados sociais, dimensionando as incertezas de forma mais crítica, por assim dizer.

Os zines são as produções e publicações realizadas por jovens em geral, indo na contra mão dos discursos dominantes. São espaços nos quais eles articulam idéias, projetos, que tentam subverter valores hierárquicos da sociedade, segundo Lankshear e Knobel (op. cit.). Utilizam

\footnotetext{
24 Tradução da pesquisadora para o termo em inglês ICTs, Information, communication technologies.
} 
para tanto, fotografias, fotocópias de imagens, textos digitados e os vendem a preço baixo (nos Estados Unidos, por exemplo, são vendidos a um dólar). O gênero, zines, fornece pistas para compreendermos como certos jovens praticam políticas culturais, como eles entendem a natureza e papel dos letramentos nas suas vidas diárias.

Essas descrições do que vem acontecendo fora do âmbito escolar demonstram que muitas escolas carecem de uma maior aceitação dos desafios dos novos letramentos e que as novas tecnologias estão demandando, cada vez mais, outras práticas culturais para o futuro do aprendiz, cuja rotina já é influenciada pelos efeitos tecnológicos. Assim sendo, na visão de tais autores, em muitas escolas a rotina de ensino e aprendizagem está firmemente baseada em currículos que acabam institucionalizando a marginalização de aprendizes “mais”, familiarizados com as novas tecnologias. Segundo Barlow (In: Lankshear, Knobel, 2005), aqueles que já incorporaram as práticas com as novas tecnologias são denominados " "natives ou insiders”' e, os outros, de “ immigrants, outsiders ou newcomers”'. A tensão escolar que daí emerge sustenta-se pelo fato de que muitas práticas pedagógicas não conseguem acompanhar o ritmo rápido das mudanças nos meios de comunicação e se encontram desatualizadas quanto à aquisição de novos conhecimentos. Evidentemente, os “outsiders”, não estariam tão excluídos, pois já experimentam e convivem com as conseqüências das produções tecnológicas fora da sala de aula, por meio de programas de televisão, filmes, jornais e revistas.

Como exemplo típico de novos letramentos, Lankshear, Knobel (op. cit.) citam o projeto de dois artistas australianos que utilizam tecnologias digitais, promovendo interações de jovens e indígenas em desvantagem social, para que os mesmos deixem de ser meros consumidores culturais e iniciem um processo de produção ativa no meio digital. Cada participante desse projeto dispõe de uma série de possibilidades para interagir: I phone, vídeo conferências informais, leitura de notícias, espaços para debate via e-mails. Eles transitam por vários ambientes, de uma comunidade para outra, de forma variada ao mesmo tempo em que editam, enviam, recebem, publicam, documentam, arquivam, criticam, ensinam, aprendem, enfim, reconstroem suas identidades dinamicamente nessa multimediação de artefatos culturais. Dessa perspectiva, para os referidos autores não há sentido algum estudar letramentos sem partir da aprendizagem das novas práticas. Grande parte da sociedade australiana já encorporou muitas dessas práticas. Tal aprendizagem requer: 1) uma descrição e análise 
cuidadosa que considere como o "insider" participa do discurso de sua cybercultura, com que maneiras ele se posiciona, suas crenças e valores; 2) posicionamento crítico de leitura, isto é, indagar a respeito de como os textos significam, quem eles favorecem da maneira que são produzidos e interpretados.

Um outro fator explorado por Castells (op. cit.) reporta-se ao fato de que as aplicações das tecnologias na revolução digital, diferente da industrial, ocorrem em matéria não física: ideias, teorias, informações. Nessa era aprendemos com o nosso fazer e, portanto, nossa participação aumenta consideravelmente. De acordo com o citado autor (op. cit.: 68-69) o que tem valor é a familiarização com os recursos e não a profusão de dados. Infere-se, portanto, que uma maior responsabilidade para filtrar o que se julga relevante nessa aparente liberdade será demandada por parte do hiperleitor.

Na visão de Landow (2006), o hipertexto viria a ser o que Derrida sugere ao tentar incluir elementos visuais na escrita como um meio de escapar das limitações da linearidade, tendo em vista o caráter pluridimensional do pensamento humano. O hipertexto é um texto digital que ocupa uma tela e é dotado de propriedade maleável sujeito às intervenções de seu hiperleitor. Há inclusão de uma porcentagem mais alta de informação não verbal que no texto convencional impresso no espaço físico, como por exemplo, o papel. De certa forma, Landow (op. cit.) pensa que a vontade de Derrida foi atendida quando da invenção do computador. Mesmo sem links para outros textos ou partes de um determinado texto, a produção textualdigital já enfatiza seu caráter virtual (Hayles, op. cit: 84) porque o computador armazena e articula a palavra como imagem; uma imagem criada num meio tão fluido e mutável quanto a água.

Uma outra característica do hipertexto é a sua capacidade de levar o hiperleitor de um ponto para outro(s). Como em Webnarah, um texto (imagem, animação, texto verbal) poderá ser associado ao outro, de diferentes categorias e de diferentes sites, estimulando, assim, a construção de conhecimento em rede. Os sistemas de hipertexto conectam: passagens do texto verbal com imagens; duas ou mais partes do texto. Em outras palavras, o hipertexto inclui a hipermídia, motivo pelo qual Landow (op. cit.) usa os dois termos indiscriminadamente. Além disso, o computador digitaliza ambos os símbolos alfanuméricos e as imagens. O que 
distingue um texto impresso tradicionalmente do texto digital são os recursos para marcar a presença intrusiva e dinâmica do hiperleitor-autor no texto digital. O movimento do cursor também indica a presença do material conectado a um determinado texto por meio de mudanças de imagens que representam o cursor: ora como imagem que se assemelha a de uma seta, ora como uma imagem semelhante a de uma mão ou outra indicação imagética, sinalizando o hiperleitor a clicar naquela mão para acessar o link desejado. A descrição de textualidade de Barthes (Landow, op. cit.) se assemelha à descrição do hipertexto, ou seja, texto composto por blocos de palavras, imagens, que ele denomina de lexia e que são associados eletronicamente a múltiplos caminhos chamados links.

Um hiperlink é formado por galáxias de links, por assim dizer. Tais links nunca se fecham, pelo contrário, eles se multiplicam de forma multiseqüencial, mesclando texto verbal e não verbal: uma multiplicidade conectada a outras multiplicidades.

Palavras e imagens digitais tomam a forma de códigos semióticos e são: fluidos, adaptáveis, abertos sem fronteiras, processáveis, duplicáveis, podem ser relocados para infinitas redes de conecção com rapidez; são simulacros de algo armazenado na memória e não correspondem a um objeto concreto localizado no espaço físico. São compostos por códigos que outros códigos podem reformatá-los, manipulá-los para diferentes propósitos, sem afetar os códigos originais. Enfim, tais características permitem que diferentes textos (=lexias) se conectem por meio de links eletrônicos. A digitalização promove condições para a hipertextualidade e, nesse sentido, o hiperleitor pode facilmente finalizar uma busca, sair do texto a qualquer momento com facilidade. Ele escolhe sua trajetória de leitura, tem oportunidade de ser autor (em alguns sistemas de ler-ecrever), de adicionar links e complementar o texto lido com outros textos de sua escolha.

Resumindo a concepção de hipertexto, termo cunhado por Nelson (In: Landow, op.cit.) na década de sessenta, o mesmo vem a ser uma forma eletrônica de texto não seqüencial que se fragmenta multiplamente, faculta ao hiperleitor fazer escolhas que o envereda para outros textos. No hipertexto, segundo o referido autor, a tela interativa favorece a leitura, pois, a capacidade que o hiperleitor tem de navegar por espaços que ele próprio seleciona, sugere uma gama de possibilidades, porém, não ilimitadamente: modificar o tamanho e o estilo da 
fonte com os quais o texto é escrito; posicionar um texto ou vários ao lado de outro(s); fazer anotações (como na lousa interativa); criar seu próprio site com diversas finalidades (anunciar seu vídeo domesticamente produzido, comprar, vender algo, publicar seus textos, socializar de forma múltipla, mais do que nunca); simular a beleza de uma celebridade por meio de fotoshop; brincar de herói que é morto, mas, que pode ressuscitar e se tornar invisível para atacar o inimigo, tornar as fronteiras entre leitor e escritor extremamente porosas. Essa noção foi anteriormente defendida por Barthes (In: Landow, op.cit.:1-143) para quem o leitor, literário, deveria se tornar consumidor e produtor do texto em estudo.

Em decorrência, podemos enfatizar a questão da divisão de poder entre escritor, designer de multimídia e leitor-usuário da Internet. Em outras palavras, estamos tratando de leitura digital de textos em rede, cujo meio permite que o hiperleitor customize sua própria experiência, crie novas formas de interação formando comunidades, ainda que de forma limitada.

Ao mesmo tempo em que há aberturas para o exercício da criatividade humana, serão exigidas do articulador da "nova mídia” uma maior responsabilidade interdisciplinar, além de habilidade técnica. É neste exato momento que recorro à acuidade que Burbules (In: Snyder, 2002) propõe: o trajeto de um (hiper)link para outro não significa necessariamente que o caminho de volta seja o mesmo que o da “partida-chegada”, pois, há mecanismos fluidos que transformam não somente o conteúdo, mas também a aparência e apresentação do texto alvo e que nos conduzem a efeitos diferentes (exs.: textos que podem ser descartados, recuperados temporariamente), cada vez que decidimos trilhar por um ou outro link.

De fato, não se concebe um final em si aos caminhos escolhidos. Há referências que nos permitem transitar de um meio para outro, o que não seria traduzido no papel. Muitas das decisões são tomadas pela aparente praticidade e/ou falta de conhecimento prévio necessário para enfocar links de busca de insumos mais relevantes do hiperleitor, que poderá ser mais facilmente manipulado pelo ponto de vista semântico do designer e/ou instituição a que ele pertence. Os hiperlinks, conforme explicam Braga e Busnardo (2004), não são construídos por acaso para servirem de atalhos de navegação. Pelo contrário, são transpassados por sentidos que favorecem seus nichos ideológicos, por assim dizer. Não podemos negar que as novas demandas de mercado cultural globalizado oferecem diferentes caminhos online para que as 
ideologias subjacentes de instituições que são responsáveis por determinados sites se reproduzam.

Não são poucos os sites com finalidade comercial que aparecem em primeiro lugar no inventário de opções para o hiperleitor. As ferramentas de busca, o gerenciamento de sites, a hospedagem de conteúdos e sua natureza são baseados em sistemas lógicos de categorização que estão longe de serem neutros e que podem induzir os leitores menos preparados para certas leituras e não outras, corroborando os posicionamentos dos autores anteriormente mencionados.

Como num livro, o hipertexto está conectado a outros hipertextos por meio de um sistema intertextual e o que o diferencia de um livro é o grande valor de impacto de informações visuais, sonoras e animações. Todos esses elementos concorrem para um jogo sígnico na tela digital que questiona a soberania de narrativas meramente verbais, conforme salienta Kress (2003).

Os inventários de opções para manipulação do texto são imensos. Dependendo do propósito do escritor-artista, de seu público alvo, diferentes recursos serão acionados para configurar fontes, formatos, contrastes de cores e tons, texturas, tamanhos de letras e traços, margens, configurações e layout de páginas, movimentos, formas, dimensões, sons diversos, jogo de perspectivismo simultâneo, a exemplo do que ocorre na homepage de webnarah.pro.br. Três imagens são construídas segundo a lógica de um recurso denominado flash. Elas se intercalam em frações de segundos, dividindo o mesmo espaço, estimulando a percepção sensorialcognitiva-social do hiperleitor.

A lógica do espaço fluido, construído por equações matemáticas binárias que traduzem informações, desafiam a inteligência e a habilidade física dos hiperleitores, especialmente os jogadores mirins de vídeo games, conforme já salientado anteriormente. Tais jogos, frequentemente condenados por muitos pais por conta da temática restrita à violência e pelo distanciamento do filho à socialização são, ao mesmo tempo, defendidos pela maioria dos jovens. Eles requerem um critério de relevância, de construção de caminhos de interpretação 
permeados por pistas visuais, configurações de códigos que regem a animação e os efeitos das estratégias de jogo defendidos por estudiosos que explicam que o raciocínio cognitivo rápido, mediante a memorização de códigos, coordenação motora, alta criatividade, socialização do jogador, (Gee, 2003, é um deles) podem constituir objetos de estudos mais aprofundados, no que tange ao desenvolvimento humano.

Aparentemente para alguns e não para outros, nesse festival de artes digitais, uma preocupação deve percorrer os estudos de letramentos e indagar sobre quem se beneficia desse paradigma digital e em que contexto, segundo orientações de Muspratt, Luke, Freebody (1997). Quando jogos, televisão, cinema, DVDs, telefones celulares e outras formas narrativas são convertidos em dados numéricos, acessíveis à leitura do computador, o resultado é uma construção de mundo mediada pela máquina e pela cultura, segundo Manovich (2001). Esse autor indaga como podemos, portanto, aprender com o rápido avanço tecnológico para que o mesmo não se transforme em uma extensão de dominação cultural e exclusão sócioeconômica, uma preocupação apontada por Giroux (2005) sobre aqueles que não são minimamente digitalizados, ou seja, que não têm acesso a uma prática de leitura mais consciente de tais mecanismos de manipulação sócio-ideológica? Reflexões sobre essas indagações constituem também o foco desta pesquisa, motivo pelo qual discorro sobre a questão da hermenêutica.

\subsection{A hermenêutica crítica e suas relações com o letramento crítico}

Vimos até aqui que o letramento crítico assume um compromisso social: analisar como uma sociedade se transforma, os motivos pelos quais ela se transforma visando, assim, a uma formação e participação do cidadão em seu meio. A ponte que conecta as propostas do letramento crítico e a hermenêutica da suspeita (Ricoeur, op. cit.), situa-se na perspectiva de uma consciência histórica caracterizada por heranças tradicionais de um passado em que o pensamento filosófico já tinha encontro marcado com certas interpretações e não outras. Põese em jogo o domínio mais vasto da hermenêutica com a linguagem, ou seja, com a polissemia reflexiva das palavras em contextos diversos. Enfatiza-se, pois, uma ação do 
pensamento e não uma mera reação aos moldes convencionais, normalmente vigiados por maniqueísmos e interpretações historicamente herdadas. Ação essa com interesse em descortinar uma ontologia da compreensão por um ser/intérprete que é capaz de tornar uma vez mais presente a cultura da antiguidade, ou seja, é sempre possível reinterpretar textos mediante a renovação de olhares; um vir a ser que contemporiza o passado, constantemente, reinterpretando-o e influenciando-o com as transformações sócio-culturais, conforme enfatizam Cervetti, Pardales e Damico (2001).

O pensamento de Ricoeur (1978) reside numa filosofia reflexiva que se fundamenta na problematização do pensar e do ser como possibilidade de auto-compreensão mediante a compreensão do outro. Inspirado no amadurecimento de Husserl (Ricoeur, op. cit.) para quem, anterior a qualquer forma de objetividade e metodologia, há um horizonte dinâmico que rege a vida, o ser vivo, abrindo, assim, caminho a uma ontologia da compreensão. A ontologia trata das relações entre os seres e das relações entre sentidos, problematizando os paradoxos da historicidade que concebe a vida como sendo significante e filosófica. O empreendimento dessa linha de pensamento interroga sobre o ser ou Daisen (op. cit.:10) que existe como o modo de compreender o ser, não como uma maneira de conhecimento histórico visto como um mero procedimento metodológico, mas o modo desse ser que existe compreendendo.

A discussão ontológica pressupõe a natureza também maleável da linguagem (Bahktin 1999), pois, o movimento da reflexão, a complexidade do pensamento filosófico não cessa de ocorrer; não há simbólica antes do homem que fala $^{25}$ (op. cit:15) isto é, a organização semântica na qual as significações que operam são multívocas. Em outras palavras, a polissemia reflexiva permite constantes atribuições de significações.

Por extensão desse pensamento, é por meio de um ato interpretativo que a questão do símbolo se inscreve numa filosofia da linguagem; é na interpretação que a multiplicidade de sentidos se manifesta; é por meio de uma inteligência hermenêutica que visa suspeitar das interpretações já institucionalizadas e que as expande, que se revela o fato de que o/a

\footnotetext{
${ }^{25}$ Interpreto que entre há e simbólica a palavra construção poderia ser inserida pelo tradutor da referida frase.
} 
fenômeno/objeto/materialidade não é somente o/a que ele(a) mostra, mas também, o que ele (a) esconde. Assim sendo, a partir de uma leitura aparentemente unívoca é possível soprar outros sentidos; de um estímulo construímos outros significados.

A problemática do sentido múltiplo conduz Ricoeur (1978; 1977) a levantar outros estudos para resituar a hermenêutica nos debates contemporâneos, de forma interdisciplinar. Visto que não há uma hermenêutica universal, as teorias dizem respeito às regras de interpretação segundo: uma hermenêutica baseada na manifestação, restauração de um sentido sob a forma de mensagem; uma hermenêutica desmistificadora e redutora das ilusões, na forma de desmascaramento; uma hermenêutica da crítica literária fundada em analogias; uma hermenêutica da escola da suspeita que possibilita a abertura de escolhas interpretativas acerca do símbolo e, portanto, de novos letramentos.

A diferença basilar entre as três hermenêuticas é de cunho epistemológico ${ }^{26}$. O primeiro caso refere-se à fenomenologia da religião que compreende os grandes símbolos cósmicos (terra, água, céu, ar), ligados aos ritos e mitos como sendo de duplo sentido. Aqui, porém, o símbolo não se apresenta como maleabilidade e equivocidade da linguagem, mas, como uma revelação de um sagrado, pois, sua interpretação já foi restaurada obedecendo a um sentido anteriormente enclausurado. Essa forma hermenêutica tem gerado crenças na clareza da linguagem, na objetividade da realidade. Objetividade esta que não permite interpretação, de suspeita.

Ainda, a fenomenologia da religião vale-se de uma semiótica que categoriza sentidos e concebe o sujeito da linguagem com auto-certeza metodológica; método e verdade trabalhando a serviço de uma exegese de fé, de doutrina eclesial. Enfim, a tradição da exegese bíblica pressupõe uma interpretação particular de um determinado texto, tal como fora concebida em relação à Sagrada Escritura. Trata-se de uma fé racional que parte da premissa de que crer e compreender compõe o círculo hermenêutico da fenomenologia do sagrado. Crer para compreender, compreender para crer, impondo a crença de que há uma verdade proclamada do símbolo. Em decorrência, o intérprete fenomenológico é interpelado por um

\footnotetext{
${ }^{26}$ Conforme ressaltado por Monte Mór em palestra, 08 de abril de 2008.
} 
silenciamento e recolhimento dos sentidos os quais não o encorajam a participar ativamente de uma reconstrução de significados.

Para a hermenêutica redutora das ilusões, uma interpretação psicanalítica propõe-se a desmascarar significados, tomando como seu pórtico o sonho. Ricoeur (1977) nos ensina que a contribuição de Freud deve-se a sua reinterpretação das produções psíquicas relacionadas com a cultura, sonho, religião, passando pela arte e moral. É interpretando a cultura que esta se modifica. Ao compreender a cultura como instrumento de reflexão, a psicanálise emerge de forma mais ampla, voltada para o domínio de uma sociologia da cultura. Ela toma o sonho como objeto de investigação de todas as expressões do desejo humano, pois, o sonho existe graças ao trabalho da linguagem. O sonho torna-se público graças ao texto de seu relato. É de um sentido (sonho) para outro sentido que se move a análise (texto do relato). Segundo Freud (Apud Ricoeur, 1978), noções de descarga, recalque, vicissitudes anunciam numa semântica: a do sentido. Donde, é possível correlacionar sonho e mito; sonho e obra artística; sonho e ilusão religiosa. Indaga-se sobre como a palavra surge no desejo a respeito daquilo que o ser desejante se empenha em dizer, mascarado e, portanto múltiplo. Nessa hermenêutica psicanalítica, a interpretação se baseia na equivocidade da linguagem, pois, o ser desejante quer dizer outra coisa, ou outras coisas, aquilo que uma vez disse, já enveredando para outros sentidos multívocos. E é no sonho que novas formas de interpretar são construídas.

Na hermenêutica da crítica literária, a imaginação poética não se reduz ao poder de formar um retrato mental do irreal. O imaginário é apenas um veículo do poder verbal, cuja dimensão ocorre por meio do onírico e do cósmico. No entanto, o trabalho do sonho é mais complexo do que a clássica questão da analogia platoniana em que $A$ é para $B$ o que $C$ é para $D$, como argumento; é mais amplo que a do simbolismo literário que parte de similitudes, correspondências, metáforas compreendidas como meras instâncias da polissemia, objetivando efeitos emotivos e não a especulação do pensamento. Nesses casos, a interpretação é exterior ao símbolo, aspecto criticado por Ricoeur (1977:26) em virtude de uma transgressão do sentido no próprio cerne da estrutura simbólica. O referido autor prossegue dizendo que o arranjo literário do mito implica uma racionalização que limita a capacidade de significação do fundo simbólico, pois, traslada-se do tempo oculto para um tempo esgotado, caracterizando uma espécie de herança em depósitos. Como resultado, a tradição se esgota ao mitologizar o símbolo. 
É Ricoeur (1978) quem enfatiza a natureza dialética, horizonte não último, mas, infinitamente reconstruível, entre texto e leitor. Ele busca reduzir a distância entre a pura subjetividade e certa objetividade (centrada no e pelo texto), ao mesmo tempo em que defende uma “abertura” do texto que pode dizer além do aparentementeo dito. Em seu dizer, ele sustenta que as hermenêuticas rivais se dilaceram, não sobre a estrutura do duplo sentido, mas sobre o modo de sua abertura, sobre a finalidade do mostrar. A fraqueza da hermenêutica refere-se a um potencial; porque o lugar onde a linguagem se escapa a si mesma e nos escapa, é o lugar onde a linguagem é dizer. (Ricoeur, op. cit.: 59).

O mesmo autor esclarece que não há análise estrutural sem inteligência hermenêutica. Em contrapartida, não há inteligência hermenêutica sem o intermédio de uma economia, de uma ordem nas quais a simbólica se expressa. A linguagem, assim concebida, opera num constante mostrar e ocultar de significados. O simbolismo consiste em revelar a equivocidade do ser que se diz de múltiplas maneiras. A compreensão desse ser está vinculada ao discurso e se realiza como sonho. (op. cit.:59). O alcance filosófico do simbolismo remete à multivocidade dos signos. Na ciência de tais signos, na linguística, há os que zelam pelo enclausuramento do universo dos signos. Ela limita-se a encontrar relações intra-significativas e relações interpretativas mútuas entre signos. O intérprete articula nos níveis: discursivo; no semântico lexical (sentido das palavras) e no semântico estruturalista (constelações sêmicas, ou seja, nas unidades de significação construídas a partir apenas de suas estruturas relacionais).

Há que ser esclarecido, entretanto, que a possibilidade do simbolismo está enraizada numa função comum a todas as palavras, numa função universal da linguagem que permite variações contextuais. O sentido múltiplo é compreendido para além da mera polissemia semântica, pois, o signo, tal como o símbolo, além de ser analisado sincronicamente, é posto em relação com os outros. Ao significar algo, não cessa de apontar valores relativamente residuais. É no discurso que há variações contextuais, ou seja, a equivocidade. A abertura do universo dos signos ocorre na articulação do lingüístico e do não-linguístico; da linguagem e da experiência vivida posto que a influência da linguagem sobre o ser e do ser sobre a linguagem realiza-se de diferentes maneiras. A hermenêutica filosófica tem por tarefa reconectar a semântica à ontologia por meio da constante reabertura do ser dito no simbolismo múltiplo. Nas palavras de Ricoeur (1978: 978:23): é mostrar que a existência só 
vem à palavra, ao sentido, à reflexão, procedendo a uma contínua interpretação de todas as significações que se manifestam no mundo da cultura.

Assim, Ricoeur funda a hermenêutica da supeita cujos pilares, ciência e arte, conferem sustentação a uma dupla motivação: pré-disposição do leitor para constantemente suspeitar e ouvir. A primeira motivação diz respeito ao não reverenciamento de ídolos; tornar-se, portanto, crítico no momento em que construímos nossos sentidos perante um dado texto, como um modo de ser no mundo. A segunda motivação refere-se à pré-disposição que podemos desenvolver para ouvir flexivelmente aos sentidos da narração, permitindo assim que os eventos criativos ocorram em meio ao texto, influenciando-nos.

São três os mestres que influenciaram Ricoeur (op. cit.) na busca da desmistificação e exposição do "real”' do aparente na religião: Marx, Nietzche e Freud, mutuamente excludentes. De acordo com o citado autor, Marx, ao analisar a religião concluiu que esta representava o ópio das pessoas, fazendo da miséria da vida uma conduta durável para ser apreciada e honrada. Analogamente, Nietzche, apreendeu a aparente função da religião que se fundamentava no esforço para a elevação da fraqueza humana a uma posição respeitável, através da promoção de virtudes como: piedade, trabalho, humildade e solidariedade. Nietzche desmascara essa ilusão propondo a fuga da fraqueza e o fortalecimento de poder humano.

Por fim, para Freud a religião representava uma fonte legítima de conforto e esperança em meio às vicissitudes da vida, mas isso não passava de uma ilusão expressada no desejo da busca pelo Deus-pai. É a partir dessa desmistificação da religião, entendida como textoevento, que Ricoeur aplica o mesmo princípio filosófico ao ato da comunicação, articulando a arte da interpretação a que se dá o nome de hermenêutica da suspeita. Por extensão, tal hermenêutica desconstroi sentidos já congelados historicamente e abre-se para um mundo do texto, um mundo que se abre para novas maneiras de ser. Logo, questionar o que o texto parece dizer torna-se um processo por meio do qual construimos novos significados. 
Há que se reconhecer, entretanto, segundo Ricoeur (1978: 126), que ao assimilarem a dúvida sobre a consciência falsa e integrarem anos ao exercício da suspeita, Marx relega-se ao aspecto puramente economicista e à absurda teoria da consciência-reflexo; Nietzsche apega-se ao biologismo chegando a uma apologia da violência; Freud é visto como articulador da psiquiatria, mas que fantasia um pan-sexualismo simplista. Tais formas de subversão da consciência em si permanecem em suspenso. O horizonte da compreensão da significação do homem demanda uma nova relação entre oculto-mostrado; patente-latente; simuladomanifesto; articular um sentido manifesto e um sentido latente, pois, o homem é histórico e dito de múltiplas maneiras.

Assim sendo, a nossa experiência no mundo avança porque temos algo a dizer primeiramente, porque temos uma experiência a trazer à linguagem. Ao falarmos, dirigimos ao mundo social, como interlocutores que abrem o âmbito de ouvintes e leitores potenciais, criando um auditório do texto. Ao mesmo tempo, é a capacidade interpretativa do auditório que torna o texto significativo. Essa abertura a um número indefinido de interpretações constitui a instância da dialética com vistas à extensão da auto-compreensão. A filosofia, dessa perspectiva, tem por função arbitrar a pluralidade das interpretações e das experiências.

Ricoeur (op. cit.) realça que depois de Freud, não é mais possível conceber a coincidência entre filosofia do sujeito e filosofia da consciência. Reflexão e consciência não mais coincidem e desse pensamento emerge um Cogito que compreende a si mesmo na e pela confissão da inadequação da ilusão, da mentira da consciência atual. Ao falar da pulsão, libido, desejo numa relação conflituosa com o mundo da cultura, Freud fala a partir de um plano da expressão, tratado como texto onírico, como dito anteriormente. É nesse meio dos signos que se manifesta a experiência como uma obra da fala, tomando a palavra e o silêncio como cúmplices. O desejo, como tal, permanece no nível do indizível. Contudo, é possível obter algo dele construindo novas percepções manifestadas na linguagem, pela via da interpretação filosófica em que o Cogito é mediatizado por todo o universo dos signos. É no e pelos efeitos de sentido que o psiquismo trabalha, restando, pois, encurtar a distância ente o sujeito na psicanálise e o sujeito na filosofia reflexiva mediante a promoção do sujeito da reflexão, lançado para diante dele mesmo. É na reflexão que ocorre o descentramento do sentido; a múltipla desapropriação e reapropriação de nós mesmos; dialética da progressão e da regressão, da teologia e da arqueologia. (Ricoeur, op. cit.: 149). 
Tributos ao trabalho da linguagem são, assim, conferidos já que é sempre a partir do que o homem diz que pode ser desdobrada a rede de significações na qual presenças desse sujeito advêm do seu próprio discurso que o engaja num acontecimento social. A hermenêutica filosófica parte da premissa de que é preciso sempre recomeçar na dimensão da riqueza e opacidade próprias do símbolo. Esses predicados nunca cessam de instruí-lo, razão pela qual uma inteligência hermenêutica é capaz de refletir sobre o caráter subversivo dos dizeres; sobre a possibilidade de se abrir para novos sentidos, como partes constituintes da história do ser. Os símbolos dotados de valores expressivos no nível semântico ofertam valores exploratórios, prisioneiros da diversidade das línguas e das culturas e, por essa razão, permanecem contingentes; não há, portanto, símbolo sem interpretação, tampouco interpretação livre de contestações.

Nessa concepção de símbolo não há pactos com a clareza de uma cientificidade de reflexão, mas sim, com a natureza equívoca do símbolo, com a contingência cultural e com a dependência de um processo interpretativo que o tenciona a ponto de expandir para outras novas construções de sentidos. Ao mesmo tempo, esse processo vela sentidos outros que são passíveis de serem revelados por meio de novas táticas de suspeita. Como resultado, constróise, dessa forma, o movimento ontológico e incessante da plenitude do símbolo, em seu caráter dinâmico e incompleto.

Ricoeur (op.cit.) nos ensina que não somos senhores de nossa linguagem (op. cit: 387) e critica a religião para a qual o sagrado mostra-se como renovação da antiga reminiscência. Também diferente da concepção de interpretação do referido autor, é a psicanálise que acaba enveredando por uma reminiscência, pois, se produz segundo a gênese de “ilusão” religiosa em que os símbolos são meios de expressão dos conflitos dos homens primitivos e da criança. O amadurecimento do ser consiste numa reapropriação de novos sentidos; numa reflexão de si; numa luta dialética em meio a forças que puxam o homem para a infância e ao mesmo tempo o lança para um momento seguinte em direção ao espírito (op. cit: 273) como sugere Hegel, ou seja, a significação da consciência não está em si mesma, mas, na simultaneidade de símbolos que arrastam a consciência para frente. Configura-se, assim, o ressurgimento de símbolos que estão sempre atrás e a emergência daqueles que estão sempre à frente. 
A reflexão não é intuição, sentido imediato ou simples crítica do juízo moral, do conhecimento. É, antes, uma reapropriação de nosso esforço para existir e por isso mesmo uma ética. O Si é reconstruído em toda a densidade de suas obras de forma ética, ou seja, a filosofia ética, pois, anteriormente a toda crítica do juízo ela reflete sobre o nosso ato de existir que desdobramos no esforço e desejo de existência. O si não é dado; é tarefa, como postula Ricoeur (op.cit.: 275):

Uma filosofia reflexiva é o contrário de uma filosofia do imediato. A primeira verdade existo, penso - permanece tão abstrata e vazia quanto é invencível. Ela precisa ser “mediatizada" pelas representações, pelas ações, pelas obras, pelas instituições, pelos monumentos que a objetivam. É nesses objetos, no mais amplo sentido que uma filosofia da reflexão não é uma filosofia da consciência, se por consciência entendemos a consciência imediata de si mesmo; A consciência é uma tarefa, dizíamos mais acima, mas ela é uma tarefa porque não é um dado.

O valor credencial hermenêutico da escola da suspeita traz para o centro da discussão uma atitude, um modo de ser do leitor, no caso desta pesquisa, do hiperleitor. Interessa compreender porque ele interpreta de determinada forma, de que escola hermenêutica, por assim dizer, está revestido. Nossas ontologias ou a falta da suspeita e criatividade poderão nos cegar diante de um texto, comprometendo, assim, a tarefa da interpretação, alerta-nos Ricoeur. A suspeita nutre-se da compreensão da metáfora como sendo um elemento que parece e outro elemento que não é. No primeiro caso, a metáfora aponta para a sua função literária, ou seja, como recurso poético de comunicação. No segundo, o referente metafórico não é localizado no sentido literal da palavra e isso gera uma tensão, na visão de Ricoeur: o significado e o referente metafóricos dependem da apropriação crítica do leitor por meio da recontextualização.

É nessa interação texto-leitor que Ricoeur (1978) amortece o tom da metáfora como mero iconoclasmo, ao mesmo tempo em que reforça o caráter da criticidade e da avaliação ética dos atos do próprio leitor. Essa ênfase se dá em meio a: linguagem poética, interpretações dessa linguagem e interpretações e vidas dos leitores e ouvintes. Essas tensões se realimentam com 
a criação de novos significados e novos referentes cada vez que o leitor mergulha no ato da hermenêutica.

Essa abordagem da metáfora por Ricoeur (op. cit.) o faz questionar a parábola bíblica uma vez que, com o exercício da suspeita, o constante processo metafórico se estabelece em oposição a rigidez de sentidos; ocorre uma espécie de transgressão na forma narrativa da parábola quando da interação intérprete, seu mundo e o texto em estudo, lançando o referente da parábola para o nível do aparente. Sua definição de parábola se dá na conjunção entre a forma narrativa, o processo metafórico e a criticidade que transgride tal narrativa. A função da criticidade é promover uma ruptura da suposta lógica da narrativa e, nesse sentido, advogar um sistema hermenêutico aberto sem absolutismos em relação ao texto ou ao ser-intérprete. Não há como escapar do perspectivismo, assim, conforme muda o contexto no qual o leitor se situa, muda-se o mundo perante o texto, desestabilizando, em decorrência, interpretações fixas.

Ricoeur (op. cit.) se refere a uma forma de conhecimento e não a única. Assim sendo, a suspensão da “intenção do autor”, postulada pelo citado filósofo, não significa que os sentidos “primeiros” do texto sejam os únicos possíveis. Aliás, é exatamente contra essa visão que a hermenêutica da suspeita, preocupa-se; trata-se de suspeitar da própria suspeita, tarefa constante do hermeneuta. A propósito desta tarefa, é oportuno explanar sobre a relação entre o tema desta tese, a pesquisa em si e as teorias de interpretação apresentadas.

As explicações teóricas enveredam para a complexidade dos letramentos na era digital na busca da compreensão de como os hiperleitores constroem sentidos. Vale lembrar que o plano desta tese conta com o fato de que os meios eletrônicos, com os quais conteúdos são produzidos e veiculados, andam em velocidade rápida e em rede, no dizer de Castells (op.cit.). Isso implica dizer que embora a escrita da tese seja influenciada pelo grande espetáculo de efeitos especiais que o computador provoca, a mesma, no final das contas, resulta subserviente às limitações grafocêntricas do papel, sugerindo a aparente primazia e sobreposição da escrita sobre as imagens, sons e animações, modalidades de linguagem que compõem o corpus desta pesquisa. A organização desta é uma escolha didática, considerando- 
se as limitações que o papel não pode deixar de mostrar, reservadas as devidas especificidades de cada um dos meios, como sempre.

Com o objetivo de enfocar a natureza interpretativa do processo desta pesquisa, parto de uma introdução que já aborda temáticas consideradas importantes para contextualizar o espaço histórico no qual me situo, no qual o projeto se delineia, como normalmente acontece na multimodalidade das homepages. Das várias temáticas que daí ressurgem, escolho uma que abre um capítulo enfocando as concepções de tecnologia, construídas a partir da experiência e conhecimento dos hiperleitores aqui pesquisados e sua implicações com base na concepção de hermenêutica crítica de Ricoeur (op. cit.) e nas teorias de letramentos, conforme desenvolvo a seguir.

\subsection{A questão da crítica nas teorias de letramentos}

Uma das características mais marcantes da produção virtual reside no fato de que o hiperleitor poderá, ainda que com certos limites, customizar a sua própria experiência de aprendizagem. É precisamente devido a essa versatilidade que o meio oferece, que os participantes dessa pesquisa adquirem o status de co-produtores dos debates em Webnarah em que redes de enlaces comuns a certos assuntos dialogam entre si. Como tipicamente ocorre no mundo virtual, as demarcações de uma categoria para outra e vice-versa rompem-se, até mesmo despercebidamente, aos olhos de quem as articula.

Pensando ser um critério didático, escolhi (hiper)links, a meu ver, de fácil acesso, não necessariamente menos complexos. Esclareço que embora as citações a seguir sejam de diferentes temáticas, o assunto em comum que as transpassa é tecnologia. É nesse assunto que a análise se concentra, ou seja, nas concepções de tecnologia que os hiperleitores demonstraram ao interpretarem uma das coleções da última moda trazida pelas marés 
tecnológicas: uma produção imagética cuja autoria se divide entre Magritte ${ }^{27}$ e os designers gráficos $^{28}$ (vide apêndice 2) em que a primeira figura refere-se à pintura extraída de livro; a segunda figura indica a pintura extraída do meio digital, não mostrada aos hiperleitores; imagem em tamanho reduzido em relação ao que aparece em Webnarah, isto é, texto da categoria imagens. Previno o leitor de que questões mais aprofundadas sobre a natureza da imagem desse mesmo recorte (Magritte. O que esta imagem lhe sugere?) serão deslocadas e enfocadas no capítulo 3. Enfatizo que respeitei o estado de linguagem em todos os excertos aqui utilizados, sem proceder às correções de qualquer natureza.

Cyberbob: O que esta imagem lhe sugere ${ }^{29}$ (imagem ampliada)

Trapito: Anos modernos. A atualidade...informática, projetos, ferramentas, contatos, várias tarefas ao mesmo tempo. E desafios cada vez maiores para conciliar tudo...

Sweet_Girl: Bem honestamente sugere uma tela de computador com uma linda área de trabalho (montanhas) e o quão dependente somos dos computadores e da tecnologia!

Nana27: Achei uma imagem muito carregada, muita coisa misturada, apesar de não estarem amontoadas, passa uma sensação de bagunça, mal organização e falta de espaço, mas ainda sim há coisas belas presentes, como mostra a montanha e a praia. Na minha opinião etá ligada à vida moderna, na qual a tecnologia é essencial e está presente o tempo todo ...as pessoas tem um ritmo muito acelerado, sempre com muita coisa para fazer, pouco tempo e espaço para organizar tudo.

Giulia: Afinal o mundo da informática é exatamente isso, a transmissão de muitos dados (incluindo imagens) ao mesmo tempo.

Como percebo, subjacente aos dizeres dos hiperleitores, uma questão de natureza técnica e suas multifaces na sociedade, acrescento outros excertos enfocando o assunto tecnologia,

\footnotetext{
${ }^{27}$ Artista surrealista belga (1898 - 1967) que criou combinações inusitadas repletas de chapéus, maçãs voadoras, esferas bipartidas, rostos cobertos, pedras, céus nublados, causando estranhamento com objetos do cotidiano; a arte dele nos faz sorrir e pensar. (Descrição da pesquisadora).

${ }^{28}$ O título da reapropriação, recriação da pintura de Magritte (A condição humana) é: Magritte editando sua própria interface. Trata-se de uma ferramenta que permite ao usuário definir o layout de interfaces para Java, salvá-lo em arquivos XML e modificá-lo sem recompilar códigos.

${ }^{29}$ Os tipos de pergunta que Cyberbob utiliza possibilitam a abertura para interações mais intensas.
} 
conforme apresentados em diversas categorias (exs.: música, lendas urbanas, outros), para em seguida, interpretá-los.

Numa outra atividade interativa, selecionei um vídeo clipe e uma música como alternativa para os hiperleitores, mas também anexei a letra da música. Parti do princípio de que os hiperleitores, que não contavam com o equipamento de auto-falantes, poderiam ao menos ler a letra da música escolhida, ainda que procedessem a uma leitura mais voltada para o conteúdo da letra e nem tanto para a multimodalidade do vídeo clipe. Segue, portanto, o comentário sobre a música Technologic ${ }^{30}$ (vide apêndice 3) em que o jogo de palavras, sons e imagens que construímos mentalmente, parecem representar verdadeiras metáforas dos tráfegos produzidos pelas economias de informação eletrônica. Observa-se nos comentários dos hiperleitores que não se concebe a vida sem a invasão autoritária da cultura da mídia e das leis de mercado em geral. Os excertos abaixo traduzem as ansiedades do cosmopolita desterritorializado com desejo de alcançar ressonância sideral, por assim dizer. Mas, as evocações acerca dos efeitos da produção multimídia na composição do vídeo clip da música não são mencionadas.

Sweet-Girl: Mostra exatamente o mundo de hoje e o que somos: escravos do que o próprio homem criou. Lembro-me de quando eu era criança e tinha tempo para as coisas. Não havia computador, brincava na rua, não era escrava do tempo. Será que isso não faz falta para as pessoas hoje em dia? Melhor ainda: será que isso conseguirá ser substituído pelo computador e outras tecnologias futuramente?

Cyberbob: Pode ser. Quem viver verá?

Observa-se que nesse ambiente são comuns interações breves, condizentes com o tipo de sociedade em que o ritmo das ações revela a rapidez e a escassez de tempo por parte de seus agentes. A própria natureza do meio digital se coaduna com interações curtas e rápidas. Todos

\footnotetext{
30 Dupla francesa que atingiu sucesso em 1997 por inovar a música tecno. Suas composições mesclam funk, rock, electro e hip-hop sendo também influenciadas por Jim Hendrix, David Bowie, Talking Heads e Serge Gainsbourg. O Daft Punk não revela seus rostos, eles se apresentam mascarados para o público e para a mídia geral. No apêndice 3, a letra da referida música foi extraída de um site sobre o grupo.
} 
aparentemente expressam os conflitos da sociedade convencional e da digital. Na atividade com a pintura de Magritte, análise que tratarei com mais detalhes no capítulo três, mas que antecipo que a montanha da referida composição magética (vide apêndice 2) para Trapito sugere a idéia de sucesso e a queda (pirar) o fracasso por não ter obtido o sucesso. Já em Sweet-Girl, observa-se como esta relaciona beleza à modernidade; um possível olhar sarcástico, construção a cargo do leitor, ao dizer que a área de trabalho é linda em meio a tantos trabalhos gerados pela modernidade digital. Modernidade esta que Nana27 verifica, pois o cenário foge á lógica da organização convencional, mesclando bagunça e aparente falta de organização. Esse parece ser o protótipo fiel da vida moderna, caracterizada por Nana27, em que as pessoas têm um ritmo muito acelerado, sempre com muita coisa para fazer, pouco tempo e espaço para organizar tudo, a ponto de pagarmos um preço alto por isso, corroborado por Sweet_Girl, na leitura intextextual da atividade sobre a música Tecnologic, ao mencionar que somos escravos do que criamos. Toda a produção do vídeo clipe da referida música insiste na repetição que exibe processos mecanicistas, uma verdadeira pirotecnia de sons, imagens e palavras asfixiantes denotando o fato de que navegar, aqui, não é preciso, conforme sugere parte do título da presente tese: Letramentos na era digital: navegar é e não é preciso.

A presença da tecnologia vem a estimular deslocamentos múltiplos e simultâneos num meio altamente fluido. Novamente, os conflitos da sociedade digital a fazem suspeitar das conseqüências desse mundo que se orienta por artefatos digitalizados, influenciando as avaliações da hiperleitura. Ao mencionar que o homem é escravo do próprio homem, esta talvez remeta a um dos motivos pelos quais Cyberbob não recebera respostas de suas perguntas (vide apêndice 9) na tentativa de aumentar a fatia de audiência. $O$ fato de que Cyberbob lançava uma pergunta para incitar mais discussões, pode ter constituído em fator inibitório aos participantes. Estes podem ter interpretado a minha intervenção como forma de controle e vigilância (Foucault, 2000). Reservo essa discussão para o capítulo 2, ilustrando as interpretações com as percepções da pesquisadora que, por sua vez, corroboram os exemplos observados nos excertos dos hiperleitores.

Como parte do processo de pesquisa, em minha rotina vivenciei o que Castells (2006: 459533) denomina virtualidade real. O mesmo autor parte da premissa de que as culturas consistem em processo de comunicação e que todas as formas de comunicação estão baseadas 
na produção e consumo de sinais, símbolos. É na simbologia que as sociedades têm atuado e por meio da qual, a experiência vivida é captada, compreendida somente imersa numa configuração de imagens virtuais em que as aparências transformam a própria experiência humana. A suposta realidade é percebida por intermédio de símbolos culturais cujos sentidos nem sempre são visíveis do ponto de vista da semântica. É por meio da natureza polissêmica do discurso (relembrando Ricoeur, 1978) que a gama de sentidos culturais se manifestam, numa mútua interação de ambigüidades interpretativas. Assim sendo, a nova galáxia digital possui a capacidade de absorver formas culturais variadas numa rede de comunicação multimodal e maleável. O espaço é de fluxo em meio a uma espécie de intemporalidade em que presente, passado e futuro se mesclam, criando um mundo de faz-de-conta. A percepção de que realidades são mundos construídos de faz-de-conta nos convida a refletir sobre novas dimensões da vida humana. A cultura da virtualidade real contribui para a noção de tempo flexível, expandido e, portanto, para novas vontades. Por exemplo, a sensação provocada por um tempo síncrono no qual o horizonte abre-se, sem começo, sem linearidade, tampouco fim. Seria o desejo de estar aqui e lá; em todos os lugares, em nenhum, simultaneamente. Explico essa instantaneidade sem barreira temporal: muitas das tarefas e dos materiais das interações foram cuidadosamente pinçadas enquanto mantinha páginas de Webnarah minimizadas a fim de buscar idéias mais criativas em outros sites. Comparava as notícias do dia da homepage dos provedores Terra e Uol, por exemplo. Ao selecionar uma determinada charge do dia, torcia para que os mecanismos de transferência de links para o site não me causassem impedimentos. Por inúmeras vezes, digitava a sintaxe, para a hospedagem de uma charge, por exemplo, de forma errada, tendo então que aprender com os erros.

A minha observação de pesquisadora participante registrou vivências e sensações novas: não ter acesso à Internet em virtude de percalços, normalmente problemas de falha na conexão, atentar para a natureza dos e-mails que recebia, cuidar para que a caixa de entrada não estivesse lotada, antenar para as notícias e eventos do dia a dia no mundo, escolher filmes e peças de teatro da semana corrente, via Internet ou jornal, para assistir a eles; ouvir certas estações de rádio, espiar sites como o Quibe loco, ler jornais, revistas, assistir à televisão (novelas, algo que não fazia há tempo!), jogar vídeo games. Tudo isso constituía o modus operandi da vida com alto investimento afetivo, analítico-crítico-reflexivo (ex.: descobri que assistir às novelas não é tão relaxante como parece, tampouco jogar vídeo games para matar, matar, renascer e continuar matando com diferentes estratégias contingenciais), além, é claro, 
da interação com livros, sites, horas à fio. Por esses meandros seguia talvez a minha mente em rede, rede em mente.

É desse cenário interativo, sem demarcações de linhas estáveis que, vislumbramos a saturação social em que o meu “eu” e dos hiperleitores se fragmentam num eterno convívio com exposições às diferentes identificações próprias e alheias, analogamente em crise, às novas formas de relacionamentos. Ao mesmo tempo em que há uma liberação de desejos de estar aqui e lá (virtualidade real), em tempo quase que real, de se multiplicar vertiginosamente, sofrendo as influências de tantos outros, em condições afins e sendo bombardeado por infindáveis fontes de informações e valores, o mundo atual, propõe novos desafios. Um deles, no mínimo, nos faz indagar sobre as novas estratégias de leitura e interação, partindo do princípio de que a verdade se multiplica e se contradiz de acordo com as condições sóciohistóricas do momento em que a mesma é discutida.

A saturação social e a complexidade de tais agressões, conforme enfatizadas nas percepções de Trapito, Sweet-Girl, Nana-27, Giulia e da pesquisadora se complementam com mais dilemas da vida expressos na forma de multifrenia. Esse conceito é aplicado por Gergen (1997) e se refere à condição do homem pós-moderno, cuja mente se ocupa por planejamentos mentais de tarefas a serem realizadas num dia livre de trabalho e se satura mediante à constelação de tais tarefas. Há uma espécie de saturação e exploração dos possíveis “eus mascarados" para experimentar novos tipos de relacionamentos e ser tratado diferentemente por outros hiperleitores, sem grandes alardes para os dias de hoje.

Na multifrenia, prossegue o citado autor, as tecnologias estimulam o desenvolvimento de uma variedade de necessidades e vontades humanas. Cada vez mais a incorporação de maiores objetivos a serem alcançados, desejos, gostos, atividades, saturam o self. Esforços são dispendidos, investimentos são enfocados na realização dos sonhos, frustrações são encontradas por esse self. E, assim, as novas relações desmistificam a suposta liberdade com a qual acreditamos ter nascido; absorvemos papéis sociais, valores que a mídia propaga. As revistas, jornais, televisão e Internet lançam auto-questionamentos: será que estamos e somos suficientemente esbeltos, com baixo nível de colesterol, cultos, viajados, protegidos, dedicados à família? Analogamente, os indivíduos com os quais mantemos contato, suscitam 
em nossas mentes outras saturações: um amigo da Califórnia nos recomenda maior atenção ao lazer; um parente de um ponto qualquer do globo fala sobre a importância dos cuidados com a saúde ou aparência pessoal e, assim, sucessivamente. Há outros valores sociais que nos perseguem em forma de explícitos ou disfarçados coro de vozes que, normalmente, escutamos ao: 1) assistirmos televisão: “sedentário, anti-social”; 2) praticando esporte sob sol forte: “câncer de pele”; 3) trabalhar até tarde da noite: “candidato à ataque cardíaco”’.

No entanto, a multifrenia não chega a caracterizar uma doença; ela acentua a condição do homem moderno, aflito, ansioso, em permanente crise de identidade, segundo o autor acima citado. A simultaneidade de auto-investimentos faz com que sua capacidade de discernimento também se multiplique; ao escolher algo, ele se depara com outras perspectivas que não aprovariam a mesma opção. A saturação social poderá instigar e ao mesmo tempo diluir as escolhas dependendo do olhar do sujeito social. Aparentemente este compõe o quadro contextual que os hiperleitores desenham ao abordarem o tema tecnologia.

Para uma leitura mais demorada, no entanto, perceberemos que é possível ir além, por exemplo, do que Giulia e Sweet-Girl apontam, de acordo com aquilo que indica a tese desta pesquisa: letramentos na sociedade digital: navegar é e não é preciso, a qual propicia a abertura de interpretação no meio digital. Relembro o leitor que o meio digital posibilita a inclusão de elementos como textos verbais, imagnes, sons e animações de forma simultânea e dinâmica, numa velocidade inimitável no papel. Giulia se vê saturada pelo mundo da informática, o qual se sustenta pela transmissão de muitos dados (inclusive imagens) simultaneamente. No caso de Sweet-Girl, esta projeta para seu presente uma nostalgia, como produto da experiência da infância, em que não se concebia como escrava do tempo. O que parece estar explícito nos pensamentos de ambas é uma epistemologia partidária dos abismos vizinhos do imediatismo; passividade frente à linearidade temporal; do divisor de águas entre passado (acolhedor) e modernidade (expectativa dianto do novo). Dessa apropriação, formas ocidentais de narrar a própria experiência parecem despontar, baseada em dizeres clichês em que o hiperleitor se enxerga como vítima, mais passiva que ativa à mercê do mundo digital. Nesse momento de dúvida, de sinais de multifrenia, características típicas da incerteza, na era digital com navegações imprecisas, conforme sugere o título da presente tese, talvez se possa concluir que a ruptura no hábito interpretativo convencional, ressaltada por Ricoeur (1978) é um processo que para essa hiperleitora, requer mais tempo para mudanças. 
Não me apóio simplesmente na instauração de uma dicotomia redutiva e totalizante das visões temporais, do ser ou não ser escravo do tempo. Penso que, tal como estabelece Ricoeur (1978), ambas as vertentes estão em permanente tensão, pois, os mesmos nunca se apresentam dissociadas da rede complexa de poder e saber, quaisquer que sejam as concepções destas últimas. Percebe-se, assim, a realimentação cumulativa, em experiências inéditas, da nossa capacidade de construirmos conceitos para além daqueles baseados nas formas efêmeras da história. Por mais que o tempo nos escape, na visão do referido autor, e por mais que escapemos de nós mesmos, o avanço e a retomada dessa fuga, no ponto de encontro com a linguagem, permitem-nos re-criar novas apreensões de sentido, que, embora fugazes, reconfiguram o jogo dinâmico e constante com a nossa interação com o tempo e deste conosco.

Dessa forma, re-elaboramos o passado com base em seus rastros para lidarmos com o tempo humano e com ritmos diferenciados de tempo. A isso Ricoeur (op. cit.) denomina de refiguração. A refiguração vem a ser exatamente a transformação da experiência humana e temporal do hiperleitor. É no ato da leitura, no processo interpretativo que o hiperleitor lê a si mesmo sem encerrar sentidos por lá resignificados. Em decorrência desse raciocínio, ler é filosofar sobre si mesmo, tributado por uma reflexão sobre como ontologias pessoais, na prática-teórica, se relacionam com epistemologias que lhes são alheias e vice-versa.

Neste capítulo que se encerra, pudemos identificar sinais dos efeitos de multiletramentos nas vozes dos hiperleitores aqui apresentados. Estes demonstraram desde sentimentos de que a rotina do cidadão moderno, em geral, tornou-se mais saturada até a percepção de que a sociedade digital está demandando novas habilidades e estratégias de sobrevivência. Ao mesmo tempo a conscientização de tais hiperleitores às novas práticas de letramentos ocorre em função da própria intervenção da máquina e das novas tecnologias em suas vidas. $\mathrm{O}$ simples fato de que interagiram nesse espaço eletrônico-digital, de forma aparentemente engajada, revela a predisposição desses hiperleitores, bem como suas habilidades mínimas para articular posicionamentos ideológicos com estranhos, de forma não presencial. Estranhos esses que estão familiarizados com a produção discursiva em meio digital, muitas vezes sem que procedessem à instrução formal de como operar em tal meio, o que vai reafirmando a minha tese de que o espaço digital promove oportunidades para ensino e aprendizagem informais, com novas epistemologias de conhecimento e performatividade. No próximo 
capítulo, veremos como a questão da linguagem tecnológica ganha intensas visibilidades na visão de mundo dos participantes da presente pesquisa e suas implicações. 


\section{Capítulo 2}

\section{A interpretação na linguagem digital: a construção de sentidos dos hiperleitores.}

Com o aporte teórico, anteriormente esclarecido, analiso os dados da pesquisa realizada com os hiperleitores percebendo que a Internet, apesar de seu espaço desterritorializado, não está ao alcance de todos. A aparente dependência eletrônica, anteriormente destacada por SweetGirl (...o quão somos dependentes dos computadores e da tecnologia!), a rapidez e expansão na troca de informações não significa que o uso do computador abrange todos, ou seja, nem todos utilizam o computador seja como ferramenta de trabalho, seja como um recurso com outras finalidades, como por exemplo, diversão, meio de estabelecer novos relacionamentos, como mero substituto da antiga máquina de datilografar.

Dentre as várias modalidades de interação construídas no site de pesquisa, concentro-me em leituras obtidas das mensagens de e-mail (vide apêndice 4) trocadas com os hiperleitores. Perguntei-lhes se há diferença entre corrente passada de mão em mão e a eletrônica para verificar se tinham consciência de que os e-mails estendem e reproduzem, online, as relações humanas offline, sem que haja um fosso demarcado entre as duas, apesar da diferença de velocidade entre um meio e o outro:

Cyberbob: Há alguma diferença entre corrente passada de mão em mão e a eletrônica?

Jean-unesp: certamente. Todo o tipo de comunicação eletrônica não consiste em comunicação plena e ideal. Uma coisa é a troca de informações, outra é a comunicação entre indivíduos. Leia Milton Santos.

Giulia: o meio eletrônico facilitou brincadeiras como as correntes...entopem a as caixas postais.

Ampcity:... a diferença reside na velocidade de propagação da corrente eletrônica... as pessoas que recebem correntes via e-mail tendem a dar menos crédito a estas já que, por via, o acesso à Internet em nosso país ainda está restrito a um determinado nicho mais bem instruído, em tese... 
Cyberbob: Dizem que, tanto os que elaboram essas informações, correntes, quanto os que respondem a elas não têm muito a fazer na vida. Dá pra aprender alguma coisa com este tipo de interações?

Rodgar: Sim, o contato direto com outro ser humano pode exprimir mais emoções, sentimentos e respostas do que no modo eletrônico,... o resultado é na maioria das vezes é que quem recebe tais mensagens apenas as deletam e sequer nem lêem, tão comum receber estas correntes inclusive muito repetitivas, hoje em dia.

Depreendemos daí que há uma crença contabilizada pelos valores de nível de instrução no trecho “"nicho mais bem instruído”'. Isso sugere um resquício do pensamento liberal em que a criticidade seria atingida apenas com a instrução ${ }^{31}$, uma asserção que não é compartilhada pelos estudos sobre letramentos na perspectiva de Cervetti, Pardales e Damico (2001). Na mesma linha de raciocínio, Jean_unesp defende que há uma diferença entre informação e conhecimento, insinuando que as correntes eletrônicas estão mais próximas das informações e não de conhecimento. Este hiperleitor parte do princípio de que haveria uma comunicação plena e ideal e insinua que a interação humana, presencialmente concebida, estaria mais próxima da sua visão de comunicação plena e ideal. Entretanto, sua construção de sentido apresenta uma sugestão de leitura, leia Milton Santos, ilustrando o que Gee (2004) denomina conhecimento distribuído, aquele que é construído a partir do local social do qual este hiperleitor fala e se posiciona ideologicamente de forma a contagiar outros hiperleitores criando espaço para conhecimento coletivo. Sem dúvida, há uma oferta de convite para mais interações propiciadas pela natureza polêmica do debate no meio fuido no qual é possível evidenciar que os hiperleitores aprendem e ensinam ao mesmo tempo.

Giulia e Ampcity ressaltam a percepção relevante para os multiletramentos de que o recurso digital trouxe mudanças temporais, ou seja, as correntes eletrônicas apresentam o diferencial da rapidez e da facilidade com que é passada, corroborando as premissas de novos letramentos enfatizadas por Lankshear, Knobel (2005). Giulia enfatiza seu descrédito com relação às informações (brincadeiras e coisas ruins) que a Internet gera. No contexto digital, há que ser lembrado que as correntes podem ser passadas de milhares para milhares de

\footnotetext{
${ }^{31}$ Monte Mór, em palestra proferida em 29 de Abril, 2008.
} 
hiperleitores. Parece que há um consenso de que o meio eletrônico é eficiente, mas, as correntes não parecem ser bem-vindas a esses hiperleitores pelo fato de que elas não apresentam credibilidade. Tais dizeres, aparentemente, remetem à crença na instrução como o único meio de desenvolver a capacidade crítica e à noção de que o usuário de Internet é o mais instruído.

O letramento crítico - assim como a hermenêutica crítica de Ricoeur (1978), já detalhada anteriormente - apresenta outras perspectivas, isto é, não há hiperleitor que apresente uma criticidade zerada, anulada, pois este está sempre dentro do discurso trazendo suas ideologias e perspectivas culturais. Do contrário, somente os grupos, supostamente instruídos, é que teriam capacidade de discernimento entre o que é brincadeira e o que é algo sério. Além disso, se no contato direto com outro ser humano, há possibilidade de exprimir mais emoções, sentimentos e respostas que no modo eletrônico, nem por isso podemos atestar que há menos mascaramentos identitários em interações presenciais. Enfatiza-se ainda o fato de que embora os participantes sejam universitários, não se assume que haja homogeneidade entre eles; considera-se que os participantes constroem conhecimentos diferenciados, sendo influenciados por diferentes loci de enunciação.

Os posicionamentos dos hiperleitores na análise acima parecem abranger também, sinais de uma leitura crítica da perspectiva modernista. É nesse exato momento que reitero algo já acentuado: o domínio único e exclusivo de conhecimentos técnicos, ou seja, a dimensão operacional, conforme visão de Green, apresentada anteriormente no capítulo um, não necessariamente, possibilita aos hiperleitores construírem sentidos mais expandidos. Em decorrência, torna-se útil contemplar a hipótese da presente tese de que é necessário suspeitar dos dizeres e das reflexões que muitas vezes concebemos como sendo fixas. Burbules (In: Snyder, 2002:75) sustenta a idéia de que os hiperlinks na Rede de Alcance Mundial (World Wide Web) funcionam de forma semântica e navegacional. Certos links, contudo, podem inibir e desencorajar alguns caminhos bloqueados por web designers no ato de sua criação. $\mathrm{O}$ citado autor nos alerta sobre possíveis limitações de possibilidades semânticas variadas sobre como se deveria proceder: questionar, indagar e subverter significados semânticos manipulados pelos '’monopolizadores”' do design. 
Há ainda características específicas da movimentação de página a página. O efeito semântico do sentido A para B não é o mesmo que de B para A, pois, enquanto os folheamos, suas direções não se apresentam de maneira simétrica. Portanto, os efeitos de sentidos são múltiplos cada vez que acessamos uma determinada página. Conforme ilustra uma das participantes: ...recebi um email falando num vírus que tornou alguns dos dados do orkut em link...fui no orkut e vi realmente que estavam em forma de link...então apaguei todas as info..nesse caso or exemplo, o aviso de vírus (se é que era vírus) foi válido, mas só em casos como este. A disposição das informações no exemplo acima, com formato de links, possibilitada pela natureza fluida do meio digital e a ausência de autorias convencionais do referido e-mail, contribuiu para a tomada de decisão da hiperleitora. Como extensão, a navegação na Internet gerou uma maneira de ser na sociedade, no sentido de que muitos hiperleitores estão oscilando entre confiar e desconfiar dos conteúdos. Maneira esta característica da reflexão interpretativa que não se prende a uma única vertente, mas, procura conviver com as ambiguidades de sentidos. Parece que a sociedade digital vem praticando um letramento crítico, se não expandido, ao menos flexível, nessa forma de pensar e agir.

Assim a precisão das navegações vai se desfazendo, desconstruindo suas marcas para reconstruí-las novamente em contextos específicos. A fim de buscar na história recente do letramento digital o aspecto retórico da web, alguns caminhos possíveis se abrem ao hiperleitor, começando pela: seleção de sites, homepages; realce do que se julga relevante; verificação de ranqueamentos de sites mais visitados; observação de que tipo de mapeamento está em jogo, que tipo de identificações, ideias e atuações são expostas; o que uma determinada configuração obscurece, exclui, para então, produzir as próprias páginas. Esse espaço permite ao hiperleitor construir significados individuais e coletivamente, comprar, vender, publicar e se socializar. Eis a oportunidade para a construção de estilos de vida e de diferentes maneiras de fazer e ser desse novo indivíduo, propiciadas pelo meio digital. A arquitetura do site pode unir ou desunir os hiperleitores por hiperlinks, as páginas podem facilitar a interação de forma direta e sincrônica, quais aberturas semânticas e navegacionais tendem a encorajar determinadas interpretações e não outras.

Tudo isso tem impacto nas impressões que são formadas sobre seu conteúdo e apresentação. Resta, portanto, a sugestão de lidar com os links, os quais não são simplesmente aleatórios, pois há limitações, sob o escrutínio crítico, de elaborar novos caminhos e constantemente 
suspeitar dos sentidos já dados, remetendo aos ensinamentos de Ricoeur (op. cit.) que parecem determinar as opções de navegação e construção interpretativa. Landow (op. cit.) nos alerta sobre o fato de que velhas e novas formas de tecnologias se encontram interconectadas, sem que uma se sobreponha a outra. Mais do que o critério de perdas e ganhos, é preciso compreender o poder representativo que cada modalidade exerce em relação à outra em contextos específicos.

Contudo, uma outra questão que deixa muitos especialistas perplexos é a crescente manipulação do medo que o meio digital implantou, como sugere o relato abaixo. Vejamos na categoria, lendas urbanas, o encadeamento de pensamentos atribuídos a minha pergunta sobre um e-mail espalhado dizendo que um vírus denominado Invitation (vide apêndice 5) estaria roubando dados dos hiperleitores. Fiz essa pergunta com o intuito de perceber se eles se interessariam por notícias sobre supostos vírus, tão freqüentemente em voga.

Margarida: E-mail enviado para você em 13/11/06 sobre vírus: Invitation. Mais uma lenda? Pinkone: a cada dia recebemos tanta coisa pela Internet, que não dá mais pra saber no que acreditar...seja aviso de vírus, correntes religiosas,. E durante as eleições então...vindos sabe-se lá de onde.. e olha que isso decidiu opinião de muita gente..não sei se o que assusta é a quantidade ou se ainda, de não se saber a fonte... mas que gera um descomforto isso gera.... eu entrei numa discussão com uma menina via email justamente sobre esse assunto, ela me mandava varios email sobre os candidatos a presidência, e particularmente sempre defendendo um e ofendendo o outro... então respondi perguntando a fonte... e ela começou a discutir o conteúdo dos casos e nunca mencionou nada sobre a fonte...Enfim, só sei que tudo isso me leva a não acreditar em mais nada...ou pelo menos na maioria das coisas que rolam...o que tb é perigoso...recebi um email falando num vírus que tornou alguns dos dados do orkut em link... fui no orkut e vi realmente que estavam em forma de link...então apaguei todas as info...nesse caso por exemplo, o aviso de vírus (se é que era vírus) foi valido, mas só em casos como este.

nana27:...concordo como o comentário de pinkone dizendo que recebemos tantas coisas pela Internet que já não é mais possível saber o que é verdade e em que podemos acreditar.

Giulia: Cada vez mais comuns este tipo de e-mail. Não dá mais para saber o que é verdade ou não. O jeito é tomar cuidado com os e-mails que recebemos. 
Cyberbob: De qualquer forma o alerta vale para aqueles que não acessarão tais mensagens?

No excerto acima verifica-se nas palavras de Pinkone, o quão uma mentira reforçada várias vezes toma a característica de verdadeira para influenciar os indecisos; a fabricação de realidades está longe de ser neutra, indicando ser uma construção altamente ideológica. Tais representações são construções sociais que refletem discursos ideológicos, ou seja, discursos que carregam valores e posicionamentos históricos, culturais, político e econômicos de determinadas comunidades, porém, não abrangem outras visões. Nesse momento, reforça-se a concepção de realidade que não pode ser captada pela linguagem, mas construída localmente já apontando para a própria transformação, segundo Cervetti, Pardales e Damico (2001). Interessante, ainda, é o fato de que Giulia sugere que a convivência com a incerteza é típica da era digital, que passa a fazer parte da vida; é a coexistência de forças com as quais ela própria lança a alternativa de se ter cuidado com os e-mails que recebe.

Um outro aspecto que chama a atenção refere-se a uma forma de resposta às minhas perguntas: a não resposta. Isso se repetiu várias vezes e escolho tratar dessa questão no final desse capítulo, simplesmente por acreditar que a ocasião é mais propícia.

O desconforto de Pinkone de não saber sobre a fonte da grande quantidade de informações revela seu desejo de origem, de fonte única e segura, um dos requisitos da lógica convencional. Assim Nana27 também expressa a vontade de saber o que é verdade em que podemos acreditar. Ambos interpretam o meio digital com fortes resquícios ontológicos para os quais a concepção de linguagem é a da transparência. A comunicação construída sem fontes fidedignas parece incomodá-las, pois aquelas expressam o desejo de segurança por meio de uma fonte primeira e confiável das informações. Elementos como fonte de informação e verdade são apenas concebidos na forma unívoca, contrariando a concepção de verdade estudada por Cervetti, Pardales e Damico (op. cit.) quando salientam que as verdades são construídas socialmente, atendendo a determinados interesses ideológicos. Entretanto, as supostas verdades não escapam do processo interpretativo que nos permite enxergar várias outras perspectivas. Ressalto que, na dúvida quanto ao que é verdadeiro ou falso, Nana27 prossegue com suas visões críticas. O dito anterior de outro hiperleitor contribui para que Nana27 reforce sua opinião concordante: Concordo com o comentário de pinkone dizendo 
que recebemos tanta coisa pela Internet que já não é mais possível saber o que é verdade e em que podemos acreditar.

O letramento crítico ocorre por meio de aprendizagem coletiva, ou seja, um hiperleitor contagia outros com idéias, questionamentos e reflexões. Tal ocorrência remete-nos ao conceito de conhecimento distribuído, da aurtoria de Gee (2003, 2004), explanado no primeiro capítulo desta tese. Nessa mediação, os hiperleitores conectam conhecimento individual às outras aprendizagens adquiridas durante a exposição em rede de suas habilidades e conhecimento. É dessa rapidez e confluência de trocas de experiências que novas atividades são possíveis de serem realizadas, ou seja, compartilhar conhecimento não é senão abrir espaços para mais produções criativas.

Retomando o tema central do diálogo acima, ficamos todos perplexos diante da poderosa fonte - Internet - que aumenta incomensuravelmente a sensação de insegurança, medo do desconhecido, os riscos do suposto/real perigo, como age um vírus invisível, mesmo valendose de programas para filtrar vírus como Norton anti-virus, CCleaner e Ad-aware SE Personal. As verdades nas mentiras e as mentiras nas verdades são provas cabais de que o mundo caminha para uma virtualidade real, a qual, conforme enfatiza Castells (2006), não se distingue da realidade, cujo conceito já pressupõe construções de fatos e identificações humanas, sem que haja uma origem, tal como no meio digital. As tomadas de decisão ocorrem forçadamente, por precaução, muitas vezes causando um custo lancinante. Senão vejamos:

Na categoria Outros (vide apêndice 6), propus que discutissem crimes online como uma oportunidade para conhecer como se posicionam e como os outros se posicionam quanto ao aparente anonimato e seus riscos, quanto às leis que poderão ser elaboradas frente à novidade:

Margarida: Crimes cibernéticos. Você já foi vítima de algum tipo de crime na Net? Qual é o seu posicionamento em relação a esse tema?

Rodgar: Bom, claro que já recebi e-mails do “governo", e “bancos” e etc., dizendo que eu devia uns tantos mil reais e que deveria enviar meus dados, depositar o dinheiro na conta tal 
and so far so on. É forçoso que eu diga também: crimes, já os devo ter cometido, aos milhares. Era um grande fã do site “sogratiz”'. Gosto da Internet pois ainda há grande “Liberdade” quando se está navegando, pode-se ser tudo, fazer de tudo, sendo bom ou ruim. Contudo, existem mais caracteres esquizofrênicos do que eu imaginava: essa liberdade está acabando, e vai acabar. Bloqueios contra download de conteúdos protegidos, orkut, e etc. Bom senso apenas não ajuda contra os crimes. Em nosso país sem educação, a única solução é: a punição, aguardem ela vai chegar... Ai de mim...

Sweet-Girl: Não fui vítima de crimes na Net, mas de ameaças virtuais sérias via Orkut (seqüestro). Muitas vezes cremos que estamos nos desenvolvendo e progredindo. Eu tenho minhas dúvidas. Saí do Orkut, Messenger, não tenho mais fotolog...tudo por medo do avanço tecnológico...contraditório, não?

Nana27: Nunca fui vítima, mas como muitos, conheço alguém que já foi. Acho que tudo tem seu lado positivo e seu lado negativo, e a Internet e seus avanços têm seus benefícios, porém também trazem com eles muitas coisas ruins e às vezes acho que os avanços tecnológicos já atingiram seus limites e com isso inicia-se a regressão, como esses crimes e outras coisas.

Nesse momento de reflexão, para contextualizar a minha análise, ouso cunhar o termo Cyberland numa alusão ao parque temático da Disneyland, considerado um atrativo turístico sofisticado na sociedade moderna. Como par da Disneyland, a Cyberland constitui-se como um novo espaço para negociações, diferentes maneiras de ser, performar, ver e ser visto num empreendimento em conjunto, pois a Disneyland não funciona sem os visitantes e estes últimos quase nada podem usufruir sem que o espaço de diversão esteja eletronicamente em funcionamento. Para os veneradores da Cyberland, o terror online surge de forma síncrona, ou não? Emerge como uma forma de crime sem que haja provas cabais para censurar a suposta liberdade de expressão. Vilão e herói convergem para um único hiperleitor longe de possuir a Internet como propriedade privada. Afinal a Internet é a terra de ninguém..., conforme disse Wednesday (vide apêndice 7). Mas, certamente, ela não é terra de todos, observaria um olhar mais hermenêutico crítico, de vez que é sabido que cada meio de comunicação tem seu público alvo, ao menos temporariamente, o que acaba restringindo a noção de democracia. 
Enquanto outros meios de comunicação, como a televisão a cabo, sonham com centenas de canais, o Usenet $^{32}$ já possui milhares deles. Assim, contraditoriamente, sentimentos como medo, ansiedade, desconforto, insegurança, diante da falta de controle sobre as próprias descobertas, revelam uma faceta produtiva: novas formas de divisão de poder entre o homem e a máquina. É desse encontro entre tecnologia e hiperleitores que surge a oportunidade de repensar os pré-conceitos que os consubstanciam, retornando a si mesmos, numa tentativa de renovar o modo de existir, em consonância com a perspectiva de Ricoeur (1978). As mudanças ocasionadas pela tecnologia representariam uma ruptura, uma contingência na vida dos hiperleitores, com diferentes visibilidades. Trata-se de “ouvir”' a ecologia da tecnologia, seus funcionamentos para, então, atualizar essa relação, suplementar os significados múltiplos (Derrida, 1997) mediante uma reflexão interpretativa que se renova em diálogo vivo.

Observa-se uma generalização de visão de mundo suscitado pela linguagem tecnológica em Rodgar quando este confessa (espaço digital para confissões, logo é possível que haja mais liberdade para hiperleitores como este) que já deve ter cometido erros aos milhares; quando pensa que pode-se ser tudo, fazer de tudo ao navegar na Internet; quando categoriza elementos entre bom e ruim; ao propor como única solução, a punição. Percebe-se, contudo, o reconhecimento de que há uma nova manifestação identitária na qual as novas faces, dentre outras, podem se mostrar: bom e mal articulando seus efeitos simultaneamente. Interpreto que Rodgar provavelmente tem cosciência de que fazer tudo na Internet seria exagero, um ato falho em seu dizer. É possível que ele esteja comparando a maior liberdade que se tem na Internet que no papel, quando o assunto é autoria, por exemplo. Nesse sentido, Rodgar estaria se aproximando de um pensamento mais característico do letramento crítico na concepção de Cervetti, Damico, Pardales (2001). Nessa, reconhece-se que sempre haverá perdas e ganhos, nuanças de valores como sendo partes de um processo incompleto de interpretação das realidades. Em Nana27 observamos uma aparente crença numa seqüência de fatos em que avanço e progresso coexistem num mesmo ambiente, aproximando-se do pensamento em rede em que os paradoxos são concebidos como oportunidades para serem suplementados, ou seja, questionados para, novamente, possibilitarem a reconstrução de sentidos, conforme ressaltam Castells (2006) e Derrida (op. cit.).

\footnotetext{
${ }^{32}$ Sistema de discussão distribuído no mundo em que os grupos são classificados hierarquicamente por assuntos. Artigos e mensagens são distribuídos para outros sistemas interconectados por uma vasta rede.
} 
A concepção de suplemento baseia-se no fato de que a linguagem e seu usuário sempre constroem realidades a partir da atribuição de sentidos culturais aos textos, aos eventos sociais. Parafraseando o referido autor, há uma lacuna entre o significante e o significado que implica na dimensão histórica e social da percepção da linguagem de modo a desestabilizar o processo sígnico, provocando a ambivalência do signo e o questionamento de certezas autoritárias. A atribuição de novos significados é sempre um processo dinâmico que permite ser reinterpretado com novas atribuições, dependendo das mudanças sofridas pelo olhar do hiperleitor e das condições sócio-históricas nas quais ele se insere. Em decorrência, o suplantar das narrativas alia-se a um adiamento, ao always already do significado, explicado por Derrida (1997) Este se ancora a um significado que, por sua vez, pode sempre ser reconstruído. Aparentemente, Nana-27 reconhece a natureza dinâmica da Internet, como momento propício para ambivalências de significados, com seus benefícios os quais enveredam para um recuo em virtude dos crimes cibernéticos.

No tocante às agressões cibernéticas, Sharif (2005) chama a atenção para o fato de que a Internet tornou visível um problema que envolve a participação conjunta de instituições educacionais, governo e sociedade para discutir o que denomina de cyberbullying que traduzo como maltratos on-line. Para esse fim, o referido professor está desenvolvendo um projeto com pesquisas qualitativas no Canadá, cujo objetivo é tentar elaborar, no final de três anos (2005-2008), orientações e abordagens para a sociedade lidar com esse tipo de agressão. Nesse projeto, é fundamental considerar o contexto das instituições, suas práticas e políticas, como as autoridades judiciais têm trabalhado com essa questão, principalmente nos EUA, Canadá e Inglaterra. Da perspectiva do referido autor, cyberbullying abrange: assédios, ameaças, intimidações por meios de comunicação, no meio físico (dentro e fora da sala de aula), no espaço virtual; envolve mulheres, crianças, homossexuais e homens. A maioria dos casos estudados revela que as vítimas nem sempre se restringem aos nichos femininos ou infanto-juvenis. Há uma correlação entre vítima e sua familiaridade com o meio técnicodigital, seu locus de enunciação, ou seja, questões ligadas à raça, gênero acabam servindo de matéria-prima para os agressores, tanto no espaço virtual como no físico. Concluindo sua pesquisa, o autor acaba por enfatizar que the virtual world is eerily similar to the real world (op. cit.: 8) e que algumas das decisões judiciais nos países acima mencionados revelaram pouco vigor e determinação para abraçar essa problemática: Cyber-threats are considered fictional and aggressors have generally been found innocent of wrongdoing. 
Como consequência, um outro fator identificado em suas pesquisas aponta a transferência de responsabilidade para as escolas. O discurso judicial postula que as escolas devem proteger os alunos e mantê-los em ambientes livres de danos psicológicos e morais, uma vez que é no espaço circunscrito à escola que os aprendizes socializam e fazem uso de tecnologias. As escolas têm demonstrado certa resistência e relutância com relação ao tema por se acharem sem conhecimento suficiente voltado para a complexidade das possíveis causas e dos contextos em que a agressão ocorre. Assim, prossegue Sharif, muitas delas acabam redefinindo o problema de bullying de modo que este se encaixe em suas abordagens e políticas tradicionais. Quando isso acontece, há uma tendência da escola culpar a vítima alegando que provocara o assédio ou dano moral, pouco fazendo na esperança de que os efeitos desaparecerão com o tempo.

Percebe-se que as leis não escapam do crivo interpretativo de quem as lê e aplica. Em decorrência, a hermenêutica crítica de Ricoeur (op. cit.) preocupa-se em abrir possibilidades de reinterpretar a convivência com tais contradições e desconfortos, próprios das produções culturais mediadas pela natureza opaca da linguagem. Assim como o artista não representa aarte como um todo, o meio, o recurso não pode responder pela totalidade das interpretações, ainda que estas sejam transformadas. ${ }^{33} \mathrm{O}$ meio digital, entretanto, parece confirmar que a

\footnotetext{
${ }^{33}$ A respeito de novas leis, no que tange aos crimes por meio da Internet, o Brasil apresenta propostas que serão enviadas à Câmara.
}

Projeto de lei cria 13 novos crimes e endurece penas. Proposta precisa ser votada na Câmara.

O ponto mais polêmico do projeto diz respeito à identificação e armazenamento de dados de internautas pelos provedores. O parecer original de Azeredo determinava que os provedores seriam obrigados a armazenar por três anos todos os seus dados para fins de investigação policial futura, além da obrigação de fiscalizar o uso e denunciar crimes para a autoridade competente. Diante das acusações de criação de um sistema de controle da internet, Azeredo aceitou flexibilizar as regras.

O texto aprovado prevê que será necessário armazenar, por três anos, apenas os dados sobre a origem, hora e data da conexão. O repasse para as autoridades policiais será feito somente com decisão judicial. Os provedores não são mais obrigados a fiscalizar, mas têm que repassar denúncias que receberem sobre conteúdos publicados.

A proposta também torna crime a disseminação de vírus, e há a tipificação de crimes, como estelionato eletrônico por meio do "roubo de senhas", que acontecem, por exemplo, com o envio de e-mails solicitando dados. A divulgação ou uso indevido de informações e dados pessoais também passa a ser crime. A pena para os crimes, em sua maioria, vai de um a três anos de prisão. (In: http:www.barueriemdia.wordpress.com/2008/07/10senado-aprova-projeto-de-lei-para-crimes-cibernéticos/). 
profusão de paradoxos em velocidade vertiginosa se multiplica e se renova cada vez mais, como veremos nas próximas linhas.

Retomando o contexto dos excertos, se na Internet há ofensas, ameaças como testemunhadas pelas próprias vítimas, hiperleitores em Webnarah, por que a autoria de tais comportamentos e usos não são facilmente rastreados? Como instrumento de escrita, na concepção de Hays ${ }^{34}$, o computador deixa para trás alguns aspectos que o papel não deixaria: rascunhos, manuscritos (exs.: produções de Wordsworth e Byron), processos, versões que podem até ser mais atraentes e relevantes para determinadas interpretações do que a versão final da obra. Não à toa, o meio digital ser tomado como a metáfora de silicone ou argila, as palavras removidas não deixam marcas, cicatrizes. Isso nos permite indagar sobre autoria, autoridade, posse e reprodução. Em documentos, comunicados de sequestradores, cartas com assinaturas, como comprovar quem é o autor? Não há caligrafia, os recursos eletrônicos flexibilizam consideravelmente as modificações (apagar, re-editar, recuperar documentos, fluidez das mensagens mesmo com back-up, cópia publicada) que podem omitir, revelar dados. Aparentemente não há idiossincrasia para identificar autoria e, no futuro, as novas gerações poderão ter dificuldade em acessar o processo de composição de uma determinada obra e até mesmo decifrá-la.

Quando um usuário utiliza a Internet para dizer coisas que alguém não diria facilmente em público de forma presencial, o anonimato poderá estimular mais produções deste gênero. Até que novas leis de mercado apareçam, perder a privacidade é também assumir uma cumplicidade de ação voluntária e/ou pressionada por fatores como mercado de trabalho, vida acadêmica, vida familiar.

No caso de Sweet_Girl, essa suspeita do avanço tecnológico que traz ameaças a ponto de a mesma deixar de participar do Orkut, “Não fui vítima de crimes na Net, mas de ameaças virtuais sérias via Orkut (seqüestro). Muitas vezes cremos que estamos nos desenvolvendo e progredindo. Eu tenho minhas dúvidas. Saí do Orkut, Messenger, não tenho mais fotolog...

${ }^{34}$ (In: Hawisher \& Selfe, op. cit: 286-293). 
tudo por medo do avanço tecnológico...contraditório, não?’’. O seu posicionamento duvida do avanço tecnológico e reconhece a natureza paradoxal inerente ao “progresso”’. Essa forma reflete a dialética em seu olhar interpretativo, pois articula a dúvida e o paradoxo da vida e está condizente com a tática de suspeitar dos significados já oficializados historicamente, defendida por Ricoeur (1978); condizente com as possibilidades de peceber outros valores culturais confome o letramento crítico sugerido por Cervetti, Damico, Pardales (2001); condizente com a desconstrução de visões que polarizam elementos. O que, ainda, chama a atenção é o fato de que o medo prevalece como critério de sua tomada de decisão: não interagir mais com comunidades online. As práticas de letramento crítico, de acordo com Muspratt, Luke, Freebody (1997), prevêem os conflitos como parte dos eventos sociais, respondendo em grande parte pela natureza dinâmica e, portanto, produtiva das transformações culturais.

A própria idéia de desenvolvimento e progresso citada pela hiperleitora acima obedece a motivos e interesses diversos, havendo sempre um preço a se pagar, conforme a história nos tem ensinado. Tais interesses ideológicos interferem no processo hermenêutico como tal, pois, neste processo de reflexão crítica, percebemos que a trajetória do que concebemos como sendo medo, deixou rastros no mundo “exterior” muito antes da invenção da máquina. É possível que o meio social permeado por várias formas de violência urbana e do qual os hiperleitores dialogam, tenha exercido considerável influência no modo de como eles se posicionam quanto à questão do medo. Os domínios do medo precedem nossa existência individual, já que o medo é uma construção social. Fiel ao pensamento filosófico, a tarefa da hermenêutica questiona propostas totalitárias e desemboca num estatuto epistemológico que inscreve a prática, a maneira de ser do indivíduo.

Gostaria de me demorar um pouco mais nessa problemática da prática. Seria deveras simples afirmar que uma reflexão ética estivesse articulada nas bases de uma única experiência como, aparentemente, sugere Sweet-Girl. Sua afirmação de que o progresso e regresso andam juntos pode ser aplicada a qualquer momento histórico. O que vai diferenciar um momento de outro, no entanto, escapa ao controle do pensador que está longe de ser senhor do sentido, concebido este último como sendo passível de reconstrução em várias perspectivas contextuais. Desdobra-se, assim, o empreendimento da tarefa da hermenêutica; o da interpretação e da compreensão, não apenas do significado já dado, mas, a reconstrução de sentidos outros, 
aludindo a uma constante relação dialógica da temporalidade histórica e prática humana, fato que culmina com uma nova empresa: indagarmos constantemente sobre nossas próprias ontologias, verdades e epistemologias. A aceitação de que a mente cartesiana pautada em separação e redução das partes de um todo, concordando coma crítica salientada por Morin (1998), não atende à compreensão da complexidade suscitada pelas práticas sociais nas sociedades tecnológicas. Sweet-Girl anuncia a suspeita das próprias verdades como participante de uma sociedade digital que desestabiliza significados rígidos. Esse diálogo com a incerteza de forma mais dialética esboçaria uma prática social sem transparência de sentidos.

É por meio da estratégia da dialética que reforço o tecido de diferenças, historicamente construído, dialogando com Derrida (1991) o qual põe em jogo a alteridade, relação dos eus e outros, como produtora de efeitos de diferenças; a identidade na diferença:

A différance é o que faz com que o movimento da significação não seja possível a não ser que cada elemento dito 'presente', que aparece sobre a cena da presença, se relacione com outra coisa que não ele mesmo, guardando em si a marca do elemento passado e deixando-se moldar pela marca da sua relação com o elemento futuro, relacionando-se o rastro menos com aquilo que se chama presente do que aquilo a que se chama passado, e constituindo aquilo que chamamos presente por intermédio dessa relação com o que não é ele próprio: absolutamente não ele próprio, ou seja, nem mesmo um passado ou um futuro como presentes modificados. É necessário que um intervalo o separe do que não é ele para que ele seja ele mesmo.

Nesse jogo de différance a contradição é trabalhada por meio da dialética, na qual forças transgridem, suplementam signos, sentidos. A mobilidade de reconstrução de sentidos outros mediante a abertura do pensamento impõe-se como moeda mais valorizada no meio digital. Abrem-se possibilidades para a acolhida ou escuta em fóruns digitais, como os acima mencionados, nos quais o exercício da tradução das diferentes formas de linguagens e identidades ganha destaque. A sociabilidade nesse ciberespaço, espaço de afinidades, pressupõe o encontro com o estrangeiro, em permanente peregrinação, sem comprometimentos, relembrando as idéias de Gee (2003, 2004). Nessas relações fluidas, 
acolher o outro ou selecionar com quem deseja interagir não fecham possibilidades futuras de reencontros. A seguir discuto a complexidade desses encontros imaginários com os outros em vários momentos.

No intuito de examinar como os hiperleitores dessa pesquisa avaliavam questões conectadas aos contextos culturais em que vivenciavam artefatos de notícias recentes da mídia, propus que debatessem sobre a questão do vestibular (vide apêndice 8). Na ocasião, o jornal $O$ Estado de São Paulo trazia uma matéria intitulada $O$ vestibular foi acusado de engessar o ensino nas escolas e nos cursinhos. O autor da citada matéria criticava os objetivos excessivamente mercadológicos a que se propõe o ensino médio. Objetivos estes centrados no despreparo do discente para competir com milhares de colegas a uma vaga em cursos de universidades públicas. Enfatizava-se a importância da formação mais abrangente do alunado.

Duas vertentes emergiram no meio digital com a minha pergunta: $O$ vestibular foi acusado de engessar o ensino nas escolas e nos cursinhos. Você concorda com esta afirmação? Por um lado, Carol defendia a forte demanda social atrelada ao bom preparo do aprendiz para enfrentar o vestibular, o qual adquiriu demasiado valor ultrapassando questões como a formação do cidadão para a vida. Em suas palavras:

Eu concordo que o ensino nas escolas e nos cursinhos tem sido engessado pelo Vestibular, já que hoje estar preparado para o tal prova é muito mais importante que estar formado para a vida.

Essa visão sugere a força dos pensamentos cartesiano e neo-liberal por parte das escolas e cursinhos. Cartesiano no sentido de que, normalmente, os resultados das avaliações dos exames de vestibular reduzem a realidade ao universo da objetividade. Dessa objetividade mensurada surge o ranqueamento de “qualidade” das escolas e cursinhos. Estes adotaram o preparo ao vestibular como uma mercadoria que atendesse aos interesses individuais dos consumidores, cujo poder aquisitivo fosse suficiente para custear tal preparo, com vistas a garantir uma vaga na universidade como pré-requisito para o ingresso no mercado de trabalho. Ao mesmo tempo, ocorre a limitação das possibiliades de escolha desses 
consumidores no tocante a oferta educacional que mais se adptasse às suas necessidades e expectativas. Essa lógica econômica deixa na decisão individual a definição do futuro. Há ampla concordância entre especialistas ${ }^{35}$ de que o vestibular na sociedade neo-liberal atende aos interesses de uma elite e reforça a noção de educação como compromiso com o preparatório de aprendizes às avaliações formais. Não por acaso, inúmeras escolas privadas competem no mercado atual, esforçando-se para comprovar os sucessos de seus alunos com a entrada desses em universidades renomadas por meio de estatísticas. Essa proposta de cunho neo-liberal acaba por dificultar outras interpretações que a educação pode assumir. Por meio da ruptura formulada por Ricoeur (1978) dos padrões convencionais de leitura, os quais apenas reproduzem as visões de outrora, Marocca discorda de sua interlocutora culpando os responsáveis pelo sistema de progressão continuada nas escolas públicas. Estes são vistos como interessados na manipulação de dados estatísticos, favorecendo à interesses políticos próprios. Em sua visão, tal sistema tem chancelado uma espécie de assalto à qualidade mínima esperada de uma instituição comprometida com a educação de seus discentes e cita como exemplo dessa situação, casos em que o alunado atinge a quarta série do ensino fundamental demonstrando incapacidade de ler e escrever minimamente bem.

Não concordo. Não foi o vestibular que sucateou a educação. O fato de não haver vagas o suficiente para todos os alunos que estão saindo do ensino médio e também daqueles que já o fizeram há muito tempo não justifica as péssimas condições que os professores têm de ensinar e os alunos de tentarem aprender. Quem engessou o ensino foi a pessoa que, dentre outrras atitudes, decidiu que não haveria mais reprovações nas escolas de ensino básico, tornando assim

\footnotetext{
${ }^{35}$ Segundo Bianchetti (2001:74-104), as políticas educativas que surgem do modelo neo-liberal respeitam a lógica econômica, promovendo a ideia de um Estado subsidiário. A lógica do mercado na educação supõe uma relação entre a oferta do serviço educativo e a demanda da sociedade. A ação do Estado se reduz a garantir uma educação básica geral liberando os outros níveis do sistema às leis de mercado. Ele permitirá as instituições responsáveis por produtos de melhor qualidade para a demanda do mercado sancionado as ineficientes, por meio da retirada da demanda. O papel subsidiário assumido pelo Estado significa o apoio à iniciativa privada, pois esse investimento sempre é menor que o requerido para sustentação de uma estrutura maior. Conforme assinala o referido autor, o neo-liberalismo opta por uma perspectiva elitista onde os erros da democracia são combatidos com menos democracia e não com maior participação dos historicamente excluídos.
} 
possível que crianças chegassem a quarta série sem saber ler nem escrever simplesmente para aumentar os índices "grau de escolaridade” e dimunuir (só no papel) o de “analfabetismo”, nas estatísticas do Brasil.

Notam-se, pois, que as intersubjetividades ideológicas das hiperleirtoras se aproximam do letramento crítico, ao se perceberem como integrantes de uma sociedade cuja estrutura educacional de vestibular exclui do cenário outros valores culturais e outras realidades como, por exemplo, as perspectivas de muitos educadores, aprendizes e pais, nem sempre contempladas. Contestando o sentido que muitas escolas atribuíram ao vestibular, sentido este que visa preparar o aprendiz para os exames classificatórios nas universidades, Carol rompe com esta visão interpretativa, valorizando a questão da formação do aprendiz para a vida. Sua crítica sugere que os resíduos históricos respondem vastamente pelo conflito das relações de poder por parte das autoridades que decidiram pela progressão continuada. Ela sugere uma forte crítica que defende a falta de poder do educador, o qual juntamente com seus aprendizes são os que mais sofrem com essa situação. Da mesma forma, Marocca questiona os índices de grau de escolaridade e de analfabetismo no Brasil, pois interpreta-os como sendo uma manipulação de dados, configurando uma realidade construída para atender à interesses de grupos sociais que tentam promover o país, exclusivamente, sob os pilares do "modelo" de progresso linear, associado ao planejamento social, científico e mecanicista. É discutindo a não neutralidade do fenômeno vestibular que as hiperleitoras observam que valores culturais são acentuados e quais são velados com o marketing adotado pelas instituições de ensino a respeito desse exame nacional. Essa forma de pensamento que problematiza um aspecto da crise educacional, ilustra um momento de criticidade segundo a teoria de Cervetti, Damico, Pardales (2001) que busca articular as diferentes nuanças de um determinado objeto de análise, no caso acima, o vestibular.

Um outro tema polêmico em voga na época, reportava-se ao feriado institucionalizado, em alguns estados brasileiros, por conta do dia da consciência negra (vide apêndice 9). Por não constituir um feriado nacional, houve uma resistência a essa comemoração instanciada por um dos hiperleitores. Sua crítica defendia que o mais adequado seria homenagear Zumbi como ícone da resistência política. O argumento baseava-se no fato de que os negros não possuem 
uma consciência diferente por motivo de raça ou cor de pele. Se assim fosse, para Arianeconstantino, deveria haver dia de consciência para cada povo representante de um tipo de cor de pele:

O dia da consciência é a maior injustiça racial da história brasileira, nós não temos o dia da consciência indígena, ou da consciência branca, comemorar o dia 20 de novembro com esse nome é um fato que ofende a idéia da data. Sabe-se que esta é a data estipulada da morte de Zumbi, o negro símbolo da resistência e política, chamar o dia de sua morte dia da consciência negra é uma vergonha a memória deste símbolo. Acho que a morte de Zumbi deveria sim ser um feriado nacional, a figura de Zumbi é mais marcante que a de outros homenageados em feriados, mas não devemos marcar a consciência como uma cor, como se os negros tivessem uma consciência diferente por sua raça. Se fosse assim, deveria haver um dia de consciência para cada cor, azul, amarela, ou até a branca.

Arianeconstantino, aparentemente, constrói uma perspectiva crítica seguindo os pressupostos do conceito de crítica por Cervetti, Pardales e Damico (op. cit.), isto é, as comunidades que defendem o feriado apoiam-se em discurso e valores culturais que os representam, mas não abrangem evidentemente outros posicionamentos e interesses ideológicos. A hiperleitora sinaliza sua capacidade de desconstruir os sentidos de um evento social, alertando-nos do perigo da discriminação ser mantida e reforçada. Ela elabora sua crítica dentro de um contexto complexo que requer reflexões que subvertem as regras criadas pela minoria que estipulou o feriado. Sua ótica sugere um movimento dialético de olhar que questiona: como o negro se vê em relação ao(s) outro(s), como ele é visto pelo(s) outro(s) e como ele se representa perante a sociedade, a nação, o mundo e da mesma forma, como a sociedade, a nação e o mundo que o cerca estão vendo-o.

Uma outra hiperleitora, Carol, complementa que deveria, pois haver um amplo debate público para discutir a situação do negro no Brasil e que um feriado adicionado ao calendário não lograria as devidas reflexões que a complexa questão merece. Ao dizer do outro e sobre o outro, Carol revela algo de sua expansão de olhar: não aceita o feriado sem que haja uma reapropriação de sentidos para si, mediante sua relação com a complexidade social-racial da qual é parte e que demanda uma diferença epistemológica por meio de maiores debates, 
discussões mais democráticas, com a inclusão de outras vozes ideológicas, pois depreende-se de sua posição que, possivelmente, a decisão sobre tal feriado restringiu-se a um nicho de agentes de poder.

O que deveria haver era um amplo diálogo com a sociedade SOBRE a consciência negra, ou melhor, sobre a situação que o negro vive no Brasil. Definir esse dia como feriado faz com que simplesmente paremos de trabalhar, como acontece em tantos outros feriados em que a reflexão sobre aquele dia é completamente esquecida pela grande maioria da população.

Percebe-se que o descrédito em relação à validade de feriados. Ao invés de promoverem debates para tranformar o meio social do negro, pelo menos é nisso que a referida hiperleitora parece crer, os feriados representam um descaso, um silenciamento de questões polêmicas. Aparentemente, houve uma ruptura crítica em seu olhar, questionando a existência do mero feriado, como sendo um fenômeno objetivo. Por meio da tática da suspeita e da transgressão do sentido convencional dado ao feriado em questão, a hiperleitora procede a um exercício hermenêutico (Ricoeur, 1978), a um ato de desconstrução (Derrida,1997), semelhantes ao do letramento crítico (Muspratt, Luke, Freebody, 1997, Cervetti, Pardales, Damico, 2001) ao mostrar o que a objetividade esconde: o fato de que sua própria natureza dinâmica faz com que a mesma seja passível de outras perspectivas, como as apontadas por Carol.

Articulando sobre as temáticas de vestibular e consciência negra, propus que discutissem: Cotas para negros na universidade: justiça, segregação? Qual é o seu posicionamento? Sweet-Girl diz que a reserva de uma cota para os negros não é a melhor saída para a crise, embora ela reconheça as injustiças, discriminações e desigualdade que tais cidadãos sofrem. Por fim, acaba esboçando um caldeirão cultural em que o hibridismo totalizante dilui as especificidades contextuais. Entretanto, suas ontologias ainda resistem em simplesmente abraçar as suas próprias sugestões, lançando mão de auto-crítica, quiçá meta-crítica, ao identificar haver uma credibilidade no referido evento: o valor da reflexão que esta questão traz à tona e que estava silenciada. A percepção de que o conflito é permanente, de que as incertezas são partes das vivências sociais. Não sei se esta é a melhor saída em: Somos todos iguais, não deveria haver cotas para privilegiar ngm. Porém, isso é utopia, o ideal. Não é o que realmente ocorre: os negros ganham menos, são menosprezados e sofrem preconceito 
sim. Enquanto a situação não for ajustada e as pessoas não compreenderem que, no fundo, somos todos iguais e seres humanos, providências devem ser tomadas para que eles não sejam prejudicados no campo profissional e pessoal. Não sei se esta é a melhor saída, mas algo deve se feito em prol de uma maior conscientização, constituem a identificação de Sweet-Girl e são inerentes ao mundo social, são exemplos típicos dos tempos atuais, da mente em rede, defendida por Castells (op. cit.), do pensamento dialético da capacidade de expansão crítica, realçado por Ricoeur (op. cit.) e Derrida (op. cit.), que buscam implodir leituras oficializadas na tentativa de constantemente reconstruí-las. Avalia-se, nesse momento, a relação possível entre hermenêutica crítica e letramento crítico.

Outros questionamentos, típicos do letramento crítico, na perspectiva de Cervetti, Pardales e Damico (op. cit.), poderiam enfocar sobre quem se beneficia mais, quem se beneficia menos com esse sistema de cotas; quem está incluído; quem está excluído; quais valores culturais estão sendo privilegiados e reforçados; quais valores são revelados e escondidos; como ele desconstrói e reconstrói hierarquias sociais e seus efeitos, conforme enfatizam Muspratt, Luke, Freebody (op. cit.). Possivelmente, em cada ambiente sócio-histórico, políticoeconômico, as especificidades locais poderiam não abranger vozes marginalizadas, pois tal sistema já favoreceria alguns grupos pertencentes a uma elite e mantenedores do poder local.

Ainda na mesma categoria notícias em webnarah.pro.br/old, lancei uma reportagem sobre o primeiro casal homossexual (vide apêndice 10) que recebera permissão para adotar uma criança, no interior do estado de São Paulo (Cyberbob: Casal homossexual adota menina. Qual é o seu posicionamento?). Contrário à visão de letramento crítico de Snyder (2008: 75 212) para quem os textos não são constructos neutros, mas, sim, produtos de valores sócioideológicos de certos grupos sociais, Sweet-Girl se contradiz ao dizer tenho uma opinião neutra. Esta não é neutra, pois assume-se que ela não está a favor nem contra a adoção e isso já caracteriza um posicionamento. Ao mesmo tempo Sweet-Girl revela mais uma crítica ao dizer: Apenas me preocupo com a garota e indaga sobre a reação de amigos da criança adotada, da mente da criança quanto à noção de maternidade: É, trata-se realmente de uma polêmica. Sim, o casal fez um gesto maravilhoso ao adotar uma criança e evitar que um futuro terrível fosse seu destino. Porém, será que a criança compreende o q se passa? Como ela encara a idéia da “mãe”, da maternidade E os amiguinhos, qdo perguntarem e fizerem comentários sobre o assunto? Não sei... não sou contra nem a favor. Tenho uma opinão 
neutra. Apenas preocupo-me com a garota. Deve haver uma explicação clara, honesta e um relacionamento aberto com ela pra que ela não fique confusa e sinta-se desconfortável.

Essa interpretação aproxima-se da manutenção da tradição, segundo a criticidade de Ricoeur (1978), ou seja, a maternidade é função exclusiva da mulher. Caso contrário, a criança estará sujeita a preconceitos, evidenciando a quebra de regras convencionais.

Ariane Constantino, acredita piamente no poder legitimado de certas autoridades no assunto, e acaba por acreditar na suposta proteção das figuras paterna-materna, visão esta socialmente construída mas que, agora, está sendo questionada. A referida hiperleitora suspeita da estrutura familiar tradicional e é receptiva ao formato familiar com dois pais. Vejamos: se uma grande equipe de psicólogos e assistentes sociais julgaram que este casal estava pronto para receber esta criança, quem somos nós, sociedade brasileira para contrastar este fato. Além disso, devemos lembrar que esta criança poderá contar com dois pais, ao invés de não ter nenhuma família.

Vimos assim que uma das características ostentada pelos hiperleitores é sua capacidade de retraduzir sentidos em forma de argumentações, levando em consideração seus valores locais e as redes sociais. Próprio do meio digital, os participantes entram e saem quando querem, tecem comentários breves ou longos sugerindo um ritmo apressado e socialmente saturado, conforme características típicas do affinity space da autoria de Gee (2003, 2004), as quais foram explanadas no capítulo um. Que este meio revela-se convidativo às construções de sentido a partir de um locus é sem dúvida evidente. Além do mais, ninguém fala impunemente, ou seja, as provocações para debates oferecidas pela pesquisadora foram atendidas na base da discórdia, concordância, complementação de pensamentos, enfim, de posicionamentos denotando forte criticidade e participação na vida política. Na medida em que avançamos em múltiplas direções de escolhas, certamente as reflexões que considerem noções teóricas, por meio das quais o pensamento reflexivo possa transformar os raciocínios reducionistas frente a uma interpretação parecem ser produtivas. 
Na minha perspectiva, os hiperleitores aproximam-se de uma prática da suspeita, na concepção de Ricoeur (1978), ao interrogarem o próprio pensamento e prática digital, ao lançarem dúvidas sobre as próprias experiências ofertadas pelo mundo eletrônico-digital. Esse pensar ocorre num movimento imprevisível, sem controle sobre um lugar presumível, pois este já se dissipou, prorrogando outros sentidos futuros. No caso das mensagens eletrônicas, anteriormente descritas, não houve predisposição para hospedar e acolher mensagens ameaçadoras. Vimos nessa relação digital que relacionar-se com outros hiperleitores é construir uma relação no mínimo produtiva; percebem-se as afinidades e proximidades tanto quanto os afastamentos próprios desse meio, conforme observados no site de pesquisa. Nesse sentido, lidar com o outro é não enclausurar os sentidos, tampouco o devir narrativo daqueles que interagem. Como já salientei, as identidades estão sendo construídas por meio de narrativas que se suplementam e, analogamente, acabam por suplementar os relacionamentos, por exemplo, em Orkut, MSN no referido site de pesquisa.

Para articular Webnarah.pro.br/old como um todo, sem seguir à risca as seqüências cronológicas e físicas das categorias, acrescento alguns trechos que aglutinam mais visões sobre a era tecnológica extraídos do “link”' intitulado Outros (vide apêndice 11):

Cyberbob: Mas afinal, MSN, Skype, Orkut, Myspace, Youtube e outros. Conte-nos porque é bom ouvir e ser ouvido nesses espaços.

Jean-unesp: Não acho muito bom ou comunicativo, participo, mas sinto que é mais por obrigação pois nesses meios as pessoas acabam te excluindo dos eventos e tal. Sempre que recebo um scrap, sinto-me obrigado a responder, às vezes nem sei o que dizer, mas tenho que responder, caso contrário sou excluído, percebe? Já para divulgar trabalhos, eventos, oportunidades e idéias, penso que qualquer meio de comunicação é válido, por isso também participo desses "internet bugs".

Ampcity: É bom ouvir e ser ouvido nesses espaços quando nos comunicamos com pessoas de nosso meio social real, isto é, gente que vemos com freqüência ou com quem mantemos algum contato presencial. A distância, por exemplo, justifica o uso do msn, o orkut, etc. O youtube é entretenimento, afinal somos curiosos por natureza. Discordo que esses espaços sejam adequados a conhecer novas pessoas, 
fazer amizades, etc. Servem como mais uma forma de interação, que nem deve ser exclusiva e quiçá a mais importante.

Cyberbob: Então, mas, tudo isso aí veio prá ficar? Será que os caça talentos ficam constantemente de olho em tais espaços? (assim como há profissionais a procura de pessoas julgadas talentosas, creio haver caça talentos que estão atentos aos produtores artísticos online para possíveis contratações e/ou terceirizações de trabalho profissional).

Giulia: São novos meios de comunicação. Às vezes podem até funcionar como ferramenta de trabalho. È divertido para se comunicar com amigos ou reencontrar conhecidos que não víamos há tempos. No entanto, sempre tem gente que não sabe usar. Aí vemos divulgação de racismos e preconceitos e coisas do gênero.

Cyberbob: Giulia, você usaria um deles em sua sala de aula?

Verifica-se que Jean-unesp oscila entre participar das interações sociais por obrigação, do contrário ficaria excluído de seu grupo social e, entre uma função mais “utilitária” de tal meio, a divulgação de autoria de ideias, trabalhos. No balanço, há o reconhecimento do que cada modalidade oferece. Ampcity reforça a questão de ser ouvido e de divulgar sua autoria, mas confere valor tradicional ao conceito de amizade a qual, pessoalmente, parece ser melhor. Tais hiperleitores, aparentemente, enquadram-se num perfil que corrobora uma tendência: a de ocultar potencialmente qualquer forma de credibilidade à Internet ao se referirem à possibilidade de novos (sérios?, seguros?) relacionamentos. Em seus dizeres não percebemos uma pré-disposição para assumir uma responsabilidade frente a esse empreendimento de forma mais otimizada. Poder-se-ia dizer que eles provêem distanciamentos, receios no mundo das relações humanas via meio digital. Giulia identifica haver a divulgação de racismo e não somente entretenimento. Esse olhar se apercebe das multifaces ideológicas da Internet. Indago se haveria um semelhante refreamento desses hiperleitores às novas amizades em ambientes mais “físicos”, quando parece haver um certo recato e individualismo, por parte dos jovens, na sociedade contemporânea.

Da perspectiva de pesquisadora, percebi lapsos ao formular perguntas e instruções para os debates. Frequentemente revelei as expectativas típicas de identidade de professora. Indaguei sobre ensino e aprendizagem não somente como ilustra o final do excerto acima (Giulia, você usaria um dele em sua sala de aula?), como em outros momentos. Com o objetivo de analisar 
as críticas e interpretações dos hiperleitores com relação à aprendizagem e exposição ao rápido acesso ao grande e maleável volume de informações no meio digital, reconheço um outro “ato falho”, ao verificar que algumas respostas, por parte dos hiperleitores, foram estimuladas pela natureza indutora de minhas perguntas. Talvez isso tenha ocorrido devido ao fato de que o espaço digital é um espaço imaginado em que produções on-line e off-line coexistem hibridamente, desqualificando, portanto, a fronteira rígida entre interação on-line e off-line, segundo postulações de Leander, McKim (2003). E nesse constructo imaginado talvez eu possa não ter resistido à tentação de participar mais diretamente e de forma diretiva.

Além dessas observações, outras há. Através de certas perguntas, chegava às respostas não previstas e que foram frutíferas para interpretações. Noto que Giulia não enfoca a minha pergunta diretamente. Tinha em mente fazer provocações, no sentido de verificar outras visões diferentes daquelas engendradas por Ampcity: sites para entretenimento. Sabemos que, subrepticiamente, os mesmos produzem espaços para manifestações que podem ser ricas e merecedoras de análises mais profundas. Não foram raros os momentos em que não obtinha respostas às minhas inserções. Relembro o leitor que a não-resposta, como forma de resposta, será enfocada mais a diante, apenas por critério de pertinência de assunto.

A respeito de design de sites, é costume ocorrer em alguns sites comerciais e de notícias casos em que os consumidores são praticamente intimidados a fornecer feedback sobre serviços, produtos e satisfação de cliente. Cito como exemplo o eBay, no qual milhões de pessoas leiloam e adquirem produtos como obras de arte, carros, roupas, jóias, etc., numa relação direta entre vendedor e comprador. O diferencial deste site reside num sistema de votação que poderá conferir, publicamente, maior ou menor reputação, credibilidade, ranqueamento aos vendedores e compradores ao final de cada leilão, enveredando, no final das contas, para uma vigilância de comportamento aceito pelo grupo. O Plastic é um site para divulgação de notícias e fóruns com comentários. Estes são avaliados e ranqueados pelo público e controlados por um moderador. Os filtros mostram apenas os comentários que pertencem a uma dada pontuação no ranking.

Sendo assim, decidi enviar um e-mail (vide apêndice 12) com cópia oculta para o grupo quase que sem êxito. Apenas dois hiperleitores me escreveram, pedindo desculpas por não terem 
acessado Webnarah.pro.br/old naquela ocasião, por motivos de força maior (deveres da faculdade, provas, absoluta falta de tempo). Como descrito nesse trecho por Pinkone, em entrevista presencial $^{36}$ :

Pesquisadora: Como é que teria sido se fosse discussão presencial?

Pinkone: Você tem um pouco mais de liberdade pra falar de um jeito menos formal, presencialmente teria a preocupação de ser mais elaborado, fundamentado do que respostas curtas, respostas sem dar muita fundamentação.

Pesquisadora: Não houve respostas prá muitas perguntas minhas e aí?

Pinkone: Pela questão de tempo.O próprio tempo que eu tinha prá entrar me limitava então eu tinha que responder rápido.

Pesquisadora: Cê já tinha feito isso com algum professor?

Pinkone: Tinha um programa prá discutir coisas da sala de aula e por presença, lá na Educação, primeira matéria que fiz.

Pesquisadora: Foi difícil?

Pinkone: Algumas eu entrava e aí (risada alta) eu desistia.

Pesquisadora: Por que muitos não participaram? O que contribuiu?

Pinkone: Qualidade de máquina que você tem, por exemplo, às vezes tava muito lento, eu desistia. Por exemplo, no meu trabalho não permite que eu, não é um trabalho de escritório que a pessoa tá na frente do computador o tempo todo. Então eu tenho horários limitados pra eu olhar os meus -emails, fazer pesquisa. A restrição de tempo onde eu vou acessar, também é limitado. Eu tava no serviço, na hora do serviço e às vezes aqui. O que me limitou a entrar é que esquecia o site porque eu lia o seu e-mail e não lembrava como era o site. Às vezes o email que eu abria não tinha lá, demorava, umas três vezes não tinha. Daí eu te escrevi, meio no final do processo. Quando entrei no final do semestre tinha que entregar trabalhos, provas nem olhava nos e-mails. Eu dependo de computador público, daí limita. Teve um vídeo, interativo, charge, que eu vi no computador do meu namorado.

Pesquisadora: Você se sentiu à vontade nesse anonimato?

\footnotetext{
${ }^{36}$ Entrevista concedida em 28/03/07, gravada em áudio-cassete, após o término das discussões on-line.
} 
Pinkone: Acho que tem liberdade de expressão.

Pesquisadora: A gente tá na mesma instituição, temos a mesma professora e...?

Pinkone: Já tem esse texto na minha cabeça, um direcionamento, tô entrando na mesma área, não é necessariamente a mesma área, você meio que absorve no seu próprio discurso, daí faz sentido, tive oportunidade de ter olhar crítico, imagem, interpretação, leitura tal, mas tentar lembrar daquilo e refletir pouco só.

Pesquisadora: Que mais, alguma sugestão?

Pinkone: Tornar, expandir o site, apesar da Web, foi restrito a um público, talvez abrir ele e largar lá prá vê se ele prolifera, sei que dá trabalho. Não conseguia voltar(Meu!). Só conseguia voltar pelo Back, no próprio site não vi.

Para Pinkone, as interações virtuais abrem espaço para informalidade, liberdade. Talvez isso seja parcialmente influenciado pelo seu locus de enunciação; está imersa no mundo acadêmico e este, normalmente, requer mais formalidade e fundamentação teórica nas argumentações. Quando consegue tempo para os rápidos comentários no virtual, respira outros ares, assume outras formas identitárias com seus pares que provavelmente têm estilos de vida semelhantes. De fato, as limitações de tempo, diferentes capacidades do computador e as falhas da construção do site, tarefas diferentes daquelas do dia a dia que requerem reflexão, num mundo em que tempo é ouro, contribuíram para que Cyberbob tivesse observadores, espiadores, ouvintes. Por outro lado, Pinkone não salienta a falta de familiaridade técnica para lidar com o site de pesquisa. Podemos apreender, portanto, que sua habilidade pode ser fruto de sua vida acadêmica-profissional que requer uma certa prática de ordem técnica.

Com vistas a expandir a "triangulação" dos dados, como descrito na metodologia de pesquisa, levei ao ar um questionário a todos os hiperleitores-participantes (vide apêndice 13) e no dia seguinte, obtive:

Pesquisadora, pergunta 1: O que levou você a participar das interações em webnarah.pro.br? 
Yohane: Gostaria de desenvolver a habilidade discursiva e crítica sobre um assunto. Achei que o site seria ideal para isso.

Pesquisadora, pergunta 2: Houve momento que lhe chamou a atenção?

Yohane: Sim, dos poucos que pude ver, mas falando de e-mails encaminhados de forma geral, existem muitos e-mails com uma ideologia forte, munida de apelo emocional e muitas vezes argumentação sem base real. Muitas vezes fui levada a questionar mensagem do corpo de email e os meios de argumentação dele.

Pesqusiadora, pergunta 3: Que modificações você faria ou me sugeriria?

Yohane: Hmm, não sei se devo opinar a respeito desse tópico, já que não consegui ter muito acesso ao seu site. Sei que não é o foco, mas uma melhor apresentação do site, um layout e organização melhor fosse mais convidativo para as pessoas se disporem a comentar (por exemplo, uma foto relativamente grande com o título e uma frase que chamem o internauta para comentar sobre o assunto).

Pesquisadora, pergunta 4: Como você interpreta o fato de que muitos não participaram?

Yohane: Posso me encaixar no grupo dos muitos que não participaram, mas tenho meus motivos. Como falei com você por e-mail, não consegui acessar a nenhuma das categorias do seu site, sequer consegui visualizá-las. A única coisa que me aparecia sempre era uma propaganda de pendrives de vários tipos...

Pesquisadora, pergunta 6: O que você aprendeu com essa experiência? ("ato falho"' da minha parte, indagando sobre a aprendizagem do outro)

Yohane: Aprendi que não devemos simplesmente ler e passar para frente certos e-mails. É preciso questionar, pesquisar e discutir sobre o assunto, sua veracidade e sua profundidade antes de reencaminhar qualquer coisa. Acredito que os e-mails informativos, fechados a um determinado grupo que vai crescendo e formando uma corrente, sejam de utilidade para a conscientização das pessoas. Falta agora o leitor saber ler, interpretar e debater sobre o assunto.

Mesmo apresentando a sua argumentação de que não conseguira acessar as categorias no site, Yohane foi bastante solícita ao me enviar feedback no final do processo. Como a pesquisa conta com recursos como webmail, Yohane pôde experimentar uma pequena parcela do que teria sido Webnarah.pro.br/old, para ela. Curiosamente, ela conseguiu se cadastrar, conforme 
atesta a lista de cadastrados. Provavelmente, ela deve ter esquecido sua senha ou login e, nesse caso, ocorreu exatamente e que ela descreveu: uma imagem de propaganda de pendrives e os espaços para que o participante entre com a senha e o login, como uma nova tentativa. Em sua reposta, acima descrita, Yohane alega que me enviara um e-mail, não especifica o que realmente disse, em que época e se a pesquisadora teria ou não respondido a esse e-mail. Para fins de registro de documentos, via mensagens eletrônicas, sempre que eu recebia ou enviava e-mails sobre a pesquisa, mantinha-os em uma pasta. Verifiquei o que havia nela e nada foi encontrado no que diz respeito ao e-mail que Yohane diz ter me enviado. Em face do ocorrido, perguntei-lhe, assim que ela me enviou as respostas do questionário online, se eu, na ocasião, teria, por descuido, deixado de responder ao seu e-mail. Ela não me retornou. Isso pode comprovar que os paradoxos e a ilusão de controle total sobre os nossos atos mediante os dos outros fazem parte das interações humanas e das premissas do letramento crítico, realçado por Cervetti, Pardales, Damico (2001). Realço, porém, que Yohane está construi sentidos a partir de seu local crítico em relação ao evento site. Ela preocupa-se em buscar uma base real de veracidade nas fontes de informações, semelhante à criticidade de certos hiperleitores anteriormente discutidos. Para os estudos de letramentos, tanto as correntes eletrônicas como as passadas via papel, não pressupõem uma origem em si, sequer um fim com direção pré-estabelecida, pois, o que importa é o processo, o deslocamento rápido e coletivo que o fato adquire com o meio eletrônico.

Apesar dos hiperleitores terem espaço para sugestões no home do site, isso não significa que estejam dispostos a interagir, nem haveria motivos para tanto, ou há? Tal pergunta é, de certa forma, respondida no fragmento abaixo:

Ampcity (respondendo à pergunta 1, do questionário): achei interessante a idéia e expor opiniões prá pessoas que não conhecemos, pois geralmente discutimos assuntos das mais diferentes modalidades entre amigos. E isso, certamente, persuade nossa forma de argumentar.

Ampcity (sobre pergunta 2): Divergências costumam chamar atenção. Houve um momento em que um dos participantes irritou-se com o tema proposto (relacionado a jogos de playstation) ao passo em que o administrador ofereceu resposta, tivemos um momento tenso, diria eu. 
Ampcity (respondendo à pergunta 3): A página não era atraente em termos visuais. Uma reformulação seria bem aceita.

Ampcity (para pergunta 4): Talvez alguns deles não tivessem acesso facilitado a Internet. Eu, por exemplo, tive que largar as discussões em meados do programa porque fiquei sem Web.

Ampcity (pergunta 5): Nem todo assunto é de interesse geral. Ao acessar o site era convencional procurar por assuntos que me agradavam. Às vezes, porém, comentava temas dos quais não gostava.

Ampcity (à pergunta 6): opinião é fundamental.

Ampcity (à pergunta 7): um verdadeiro perigo. De que adianta ter acesso cada vez mais rápido à tecnologia, seja ela para entretenimento ou informação, se a sociedade está cada vez mais incapaz de ler o que está a sua volta??? Interpretar é preciso e informação não significa formação.

Parece uma ironia proposital o fato de que o site visa trabalhar interpretações sobre assuntos dentre os quais imagens e ser tão pouco atraente visualmente, como disse Ampcity. Sua franqueza não expressa simpatia por alguns dos conteúdos e nos ensina que não há porquê ter a expectativa de que todos deveriam gostar e se interessar pelas mesmas coisas; critica o uso de tecnologia por uma sociedade carente de formação interpretativa. Observa-se que o fator atração constitui-se em requisito relevante para o usuário. Esse discurso reflete marcas do discurso de professor, perpassado por uma tentativa de moralizar e de protestar contra os perigos da falta de criticidade generalizada e da tecnologia em si. Discutir opiniões com o desconhecido para este hiperleitor(a?) aparentemente sugere a crença em conhecimento “concreto”' acerca de alguém, via Internet. Julgo o feedback online de extrema importância para a minha própria aprendizagem. No início da pesquisa, houve uma tendência da minha parte de esperar por respostas imediatas de todos, em todas as categorias.

De fato, não se deve esperar que os gostos e interesses sejam construídos de forma homogênea. A riqueza do debate ocorre exatamente quando as diferenças navegam concomitantemente, conforme sugere o título dessa tese: Letramentos na sociedade digital: navegar é e não é preciso. As contingências do processo também fazem parte das ações que são tomadas pelos hiperleitores. Aparentemente, Ampcity demonstra que sua rotina está 
temporariamente distanciada do acesso à máquina, ao dizer que ficou sem Web, sem a possibilidade de acessá-la com um outro computador, em outro local. Chama a atenção também o fato de que um falante de língua portuguesa dificilmente faria uso de ao passo que (enquanto que) como sendo ao passo em que (inexistente em português no contexto de uso equivalente a ao passo que). Seria Ampcity um falante não-nativo de português? Na realidade, isso demonstra novamente as possibilidades múltiplas de construção de sentido, de identidades que se proliferam no meio virtual. Curiosamente, muitos se esconderam durante o debate, mas, se revelaram, fortemente, em muitos outros aspectos por meio de questionário. Eis aí uma indicação de que Webnarah.pro.br/old não é uma comunidade em que os membros se conectam por uma fidelidade prolongada. Ao contrário, trata-se de um espaço de contradições, de contingências, como as que ocorreram nas respostas acima.

Tanto Yohane como Ampcity destacam a necessidade de interpretar. A primeira realça que desenvolver a habilidade discursiva e crítica para debater é importante antes de comprar a idéia dos conteúdos de e-mails. Da mesma forma, Ampcity diz que opinar é fundamental e que há uma diferença entre informação e formação do cidadão. Tais posicionamentos conduzem à percepção de que cuidados são necessários para articular com as criações da mídia. É possível verificar nesses hiperleitores uma atitude, um modo de ser diante do texto, tal como esclareci, segundo nos ensina a hermenêutica crítica de Ricoeur (1978), confirmando a minha hipótese inicial de que os leitores já exercitam suas capacidades críticointerpretativas, sendo estas possíveis de ser expandidas, estimuladas pelo espaço digital, afinal, navegar é e não é preciso; afinal, as construções de sentido estão sujeitas às mudanças interpretativas.

Passo agora a explicar o silêncio durante momentos das interações no site, como já ventilados anteriormente. De acordo com Cará Junior (2006) a presença de um moderador pode constituir-se em agente de inibição numa sala de interação virtual.

Nesta pesquisa, a pesquisadora pode ter sido interpretada por alguns hiperleitores como sendo uma moderadora, portanto, dotada de certo poder, assim como Foucault nos ensina em suas teorias (2000). Acresce-se a isso o fato de a mesma estar imersa em uma instituição educacional da qual faz parte. Portanto, não há como negar o aparecimento de uma arquitetura 
que desvenda uma hierarquia. Isso poderá ter representado um fator inibidor que poderia ter rompido a espontaneidade por parte de alguns hiperleitores. Tomemos como exemplo ilustrativo o evento que Ampcity descreve: Houve um momento em que um dos participantes irritou-se com o tema proposto (relacionado a jogos do playstation) ao passo em que o administrador ofereceu resposta, tivemos um momento tenso, diria eu. Esse momento pode ser considerado um ato de controle da moderadora, da administradora, de Cyberbob e isso pode ter desencorajado outras participações. Não interagir no site de pesquisa já caracteriza uma manifestação do exercício de poder, ou seja, um posicionamento de resistência.

Dessa forma, o hiperleitor ativa também uma espécie de micro-poder, conceito utilizado por Foucault (1979) referindo-se às atitudes de resistência. Nas salas de bate-papo on-line não há uma hierarquia pré-estabelecida em que um líder, coordenador, conduz e controla as interações, o quê, quando e como dizer algo. Webnarah constitui-se numa prática social regida pela mobilidade de controle. Foucault (2000) define o poder como uma força social praticada de forma dispersa, sem localização específica e fixa. Ele é exercido historicamente de forma diferente tanto por um indivíduo como por um grupo. Os efeitos de verdades são produzidos, assim, nas interações e atos dos hiperleitores. Estes se vigiam e são controlados por Cyberbob, dotado de poder administrativo. Isso não isenta os hiperleitores de iniciativa e controle coletivo; os posicionamentos em forma de silêncio, de espiador (denominado lurker, Leander, McKim, 2003) já são posicionamentos que os evidenciam e os inserem no jogo ideológico. Esse tipo de poder, segundo Foucault (op. cit.), visa a incitar comportamentos e disciplinas no outro para que ele produza algo segundo os interesses daquele que concentra mais poder, ao menos temporariamente.

Nessa análise, retomo a construção de panóptico de Benthan (In: Foucault, op. cit.), metáfora com a qual Foucault explica o exercício dinâmico de poder. O panóptico apresenta uma arquitetura de torres e vigias dispostos de maneira que o vigia de uma torre observe os vigiados sem que ele seja visto. Mesmo que o suposto vigia esteja fisicamente ausente, o que importa nesse panóptico são os efeitos de poder que daí emergem: construção de medo, incerteza, insegurança, enfim, a idéia de ser vigiado o tempo todo. Ocorre que o vigiado também exerce controle sobre os outros, produto do comportamento gerado pelo próprio caráter coletivo da ação disciplinar. Ao não responder as perguntas, muitas incertezas são produzidas no controlador. Merecedor desse ponto é o momento em que Sweet-Girl desconfia 
da corrente eletrônica que recebera, já descrito anteriormente e, em decorrência, constrói significados que influenciam sua decisão de sair do Orkut, ou seja, não se sujeitar a um poder invisível e eficiente.

Com essa base, Webnarah não deixa de ser um panóptico virtual. Cyberbob é o único participante que pode acessar a lista dos hiperleitores cadastrados, os mecanismos de descadastramento, os recursos para correção do que havia sido lançado no ar (exs.: erros de digitação, gramática, fonte, dados), os mecanismos para apresentar novas enquetes, novos temas nas categorias. Seu poder, entretanto, é compartilhado. Os hiperleitores que se cadastraram, mas não participaram pelo menos uma vez, com comentários sobre os temas propostos, são de conhecimento exclusivo de Cyberbob. Estes receberam todos os e-mails que divulgavam materiais e tarefas complementares ao site. Donde, Yohane, como tantos outros, puderam ter uma idéia de alguns dos conteúdos de mensagens eletrônicas, sugeridas para os debates. Ao receber a mensagem eletrônica, via cópia oculta para pequenos grupos de cada vez, o hiperleitor sabia que havia outros colegas recebendo a mesma mensagem e até poderiam opinar, clicando em seguida em responder a todos. Em outras palavras, haveria como ser ouvido através dos recursos de webmail e não necessariamente no interior de Webnarah.

Aprende-se com Ampcity que a musa da atualidade continua sendo a tecnologia e seus perigos. Ocorre que é o hiperleitor dotado de uma criticidade e habilidade técnica que contribuirá para que este reinado não esteja ameaçado. Ao contrário do que muitos pensam, nesse grupo investigado, não percebi um encantamento, uma sedução exagerada por tecnologia, ao menos por parte destes hiperleitores. Insofismavelmente, a tecnologia se presta às funções utilitárias (ferramenta de trabalho, divulgador de trabalhos, manter contato com os pares, do mesmo meio social já que não confere credibilidade para novas amizades, tal parece ser a crença de certos hiperleitores) e ao entretenimento por força da curiosidade humana. Os que não sabem tirar bom proveito da ferramenta, no sentido convencional, podem criar problemas culturais. Chegar a essa conclusão, a de que a ferramenta pode ser utilizada para diferentes propósitos, não põe em curso novidade alguma. A perspectiva dos participantes, aparentemente, envereda para a aparente crença de que o computador está a serviço do homem de múltiplas formas mesmo havendo recorrência de uma faceta sobre outras. Sendo assim, a dinamicidade, própria do meio, poderá gerar outras transformações. 
O que de fato trouxe a minha reflexão ao comentário de Jean_unesp ( “ ‘..participo, mas sinto que é mais por obrigação pois nesses meios as pessoas acabam te excluindo dos eventos $e$ tal'’.), foi o risco mencionado por Jean-unesp de ser excluído socialmente, inclusive pelos seus pares e quem sabe do mesmo espaço de afinidade, o qual prevê interesses afins entre os participantes, na concepção de Gee (2003): “tenho que responder caso contrário sou excluído’’. Pelo menos no Orkut, o hiperleitor pode exercer maior controle sobre quem é aceito, ou não, como novo integrante de sua comunidade. Da mesma forma, outros poderão recusá-lo a participar de outras comunidades. Independente desse recurso, a possibilidade de ser mesmo esquecido ou excluído existe na medida em que há fóruns e espaço para divulgação de eventos no referido site. Não à toa, Jean-unesp vê-se obrigado a interagir mesmo contra sua livre e espontânea vontade. Algumas reflexões nesse sentido poderiam sugerir que podemos ser escravos daquilo que criamos, segundo Ampcity. Por extensão desse raciocínio, talvez se possa concluir que somos vítimas da própria saturação social que nos constitui.

Outras opiniões sobre inclusão sócio-digital ressurgem, atentando-se para as surpresas que se transformam em estímulos, catalizadores para aprendizagens críticas relacionadas à educação. Temos, pois, uma charge enfocando a questão da inclusão (vide apêndice 14):

Cyberbob: Inclusão digital. Não é um barato? Clique aqui> 


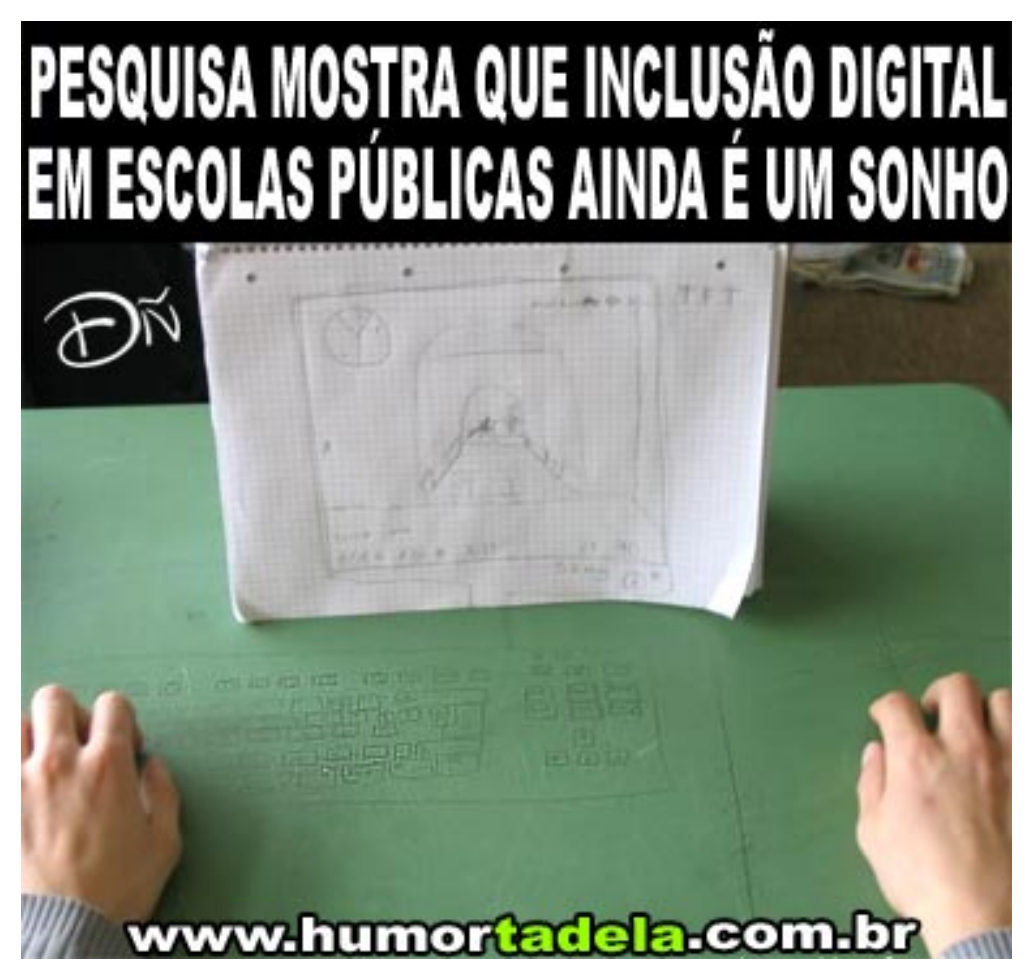

Sweet-Girl: Não acho um barato, acho triste essa charge. Demonstra claramente o descaso para com as comunidades carentes e o fato de que NUNCA terão verdadeiramente acesso à tecnologia ou conseguirão se aperfeiçoar, a não ser que sejam muito persistentes. Realmente, a inclusão digital ainda é utópica.

Pinkone: Que maldade! Mas infelizmente é isso mesmo, não é? Não sei o que a pessoa que fez essa charge acha, mas não deixa de ser uma denúncia do disparate de se ter um meio de comunicação tão revolucionário como a web e milhões de pessoas (jovens) não tem nem noção de como se usa um computador.

Nana27: Achei a charge bem realista, e também muito triste. Infelizmente ela mostra a real situação de muitas das crianças do nosso país, para as quais a inclusão ainda está longe.

Temos exemplos claros de economia de atenção salientado por Goldhaber (Apud Lankshear, Knobel, 2005) praticada entre os hiperleitores que demonstraram preocupação nessa questão inclusão digital. A respeito do conceito de economia de atenção, o citado autor esclarece que uma das tendências a caracterizar o ambiente digital é o investimento qualitativo que busca satisfazer necessidades não materiais, ou melhor, as não monetárias. O citado autor argumenta que as economias são governadas pelo que há de escasso em determinadas épocas. No meio digital, isso se aplica. A propagação de dados é realizada de forma ampla, rápida e econômica. 
Portanto, informação é o que há em abundância, porém, um elemento escasso que agora emerge denomina-se atenção. Há um crescimento contínuo e veloz do número de indivíduos acessando a Internet tentando oferecer e obter atenção de um público cada vez mais expandido. Para vencer competições acirradas, as produções on-line utilizam-se de multimídia sofisticada em sites que fornecem a ilusão de atenção para satisfazer essa necessidade afetivacultural, em voga, e conseqüentemente, manter a fidelidade de seus usuários por mais tempo. Forma-se assim uma economia de atenção, pré-requisito para a sobrevivência, chegando a ultrapassar interesses de ordem material. Nas palavras do autor: attention transactions, which already are far more numerous than monetary transactions will come to dominate even further $^{37}$.

Assim, observei que a vontade de responder à provocação embutida na pergunta sobre a charge foi atendida. Cyberbob agradece à atenção de seus interlocutores que apresentaram verdadeiros brainstorming ${ }^{38}$, algo que muitas vezes não acontece na sala de aula, não raro local de desperdício de conhecimento e experiência dos aprendizes, ainda que limitados, os quais não chegam ao alcance de seus mestres.

Os hiperleitores acima relativizam o mito da Internet como espaço mais democrático para a comunicação humana. Notam-se aspectos nos dizeres, quais sejam: 1) Sweet_Girl quando enfatiza que as comunidades carentes nunca terão verdadeiramente acesso à tecnologia e que a inclusão digital é utópica; 2) Pinkone dizendo que milhões de pessoas (jovens) não têm nem noção de como se usa um computador; 3) Nana 27 pensa que a inclusão para muitas crianças do nosso país ainda está longe. Os mais privilegiados são os que aparentemente se beneficiam desse fenômeno, ainda que seja da perspectiva meramente tecnicista. Contudo, essas assertivas sugerem uma perspectiva elitista. Segundo Buzato (2007), vários usuários da Internet acessam-na mesmo não dispondo de poder aquisitivo para a aquisição de máquinas, seja por meio de amigos, de Lan Houses, de comunidades locais que permitem a participação de muitos jovens no universo online. Em decorrência, alguns jovens e crianças supostamente marginalizadas, convivendo com desigualdades sociais, conseguem achar brechas e melhores

\footnotetext{
${ }^{37}$ Disponível em: http://www.firstmonday.org/issues/issue2_4/goldhaber/.

${ }^{38}$ Termo usado para designar as idéias que mentalmente nos ocorrem quando tratamos de um determinado assunto; tempestade de idéias.
} 
oportunidades de trabalho e até maior participação política, pois estes, já constroem epistemologias típicas do meio digital no cotidiano, além de apresentarem significativas habilidades técnicas. Retomando as preocupações de Muspratt, Luke, Freebody (1997), o conhecimento sobre Internet não possibilita necessariamente bons usos da mesma. Aparentemente, alguns hiperleitores acreditam que o poder reascenderá das mãos dos melhores equipados, dos melhores armados, com tecnologias de penúltima geração já que a última é sempre projetada no devir.

Sem dúvida, o letramento digital conduz os educadores a refletir sobre as dinâmicas no fluxo de informação na sociedade em rede. As escolas em áreas menos privilegiadas ganharão algo indiretamente, ficando de fora? Como as escolas se beneficiariam com o Projeto Negroponte $^{39}$, mesmo sabendo que licitações referentes a certas empresas foram canceladas pelo governo federal? ${ }^{40} \mathrm{E}$ aqueles que são auto-didatas e os persistentes como aventara Sweet-Girl, estariam se beneficiando de que forma? Mesmo em ambientes equipados com computadores e outras tecnologias de ponta, percebem-se riscos dos educadores (dividindo a responsabilidade com a industrialização do ensino e os resquícios patriarcais), sem conhecimento expandido e habilidades, reforçarem e reproduzirem epistemologias que novamente contribuem para segmentações sociais: aprendizes ricos, brancos, navegando no espaço digital a qualquer custo, a minoria-maioria composta pelos etnicamente multiculturais.

\footnotetext{
${ }^{39}$ Nicholas Negroponte, do MIT (Massachusets Institute of Technology), é um dos idealizadores desse projeto que visa desenvolver e vender laptops a 100 dólares ou menos em países em desenvolvimento, incluindo Brasil, Tailândia, Egito, Nigéria, Índia e China. Os governos e as empresas privadas subsidiam as máquinas. Segundo André Barbosa filho, acessor especial da Casa Civil, os estudos sobre a viabilidade da adoção do projeto no Brasil seriam discutidos ao longo de 2006. A Nigéria encomendou um milhão de máquinas, mas, depende da mesma decisão de pelo menos quatro outros países para viabilizar o custo de produção. A Índia descartou essa possibilidade por não acreditar na maturidade do projeto. Disponível: http://www.estadão.com.br/tecnologia/informatica/notícias/2006/jul/27/65.html, http://agenciact.mct.go/index.php/content/view/31216.html.
}

\footnotetext{
${ }^{40}$ Brasília - O Ministério da Educação (MEC) confirmou hoje (7) o cancelamento do pregão eletrônico para a compra de 150 mil computadores portáteis (notebooks) educacionais que seriam distribuídos para 300 escolas públicas de todo o país. Procurada pela Agência Brasil, a assessoria do MEC se limitou a confirmar o cancelamento, sem explicar as razões, se um novo pregão será realizado ou mesmo se o projeto Um Computador por Aluno (UCA) será suspenso. (http://www.agenciabrasil.gov.br/noticias/2008/02/07/matéria/view)
} 
Servem-se dessa condição para esgotar seu arsenal de criatividade para buscar outras ações que não as das escolas em geral.

Minhas leituras multimodais me fazem ancorar em maiores diálogos entre os cientistas e os estudiosos de cultura, visando problematizar a coexistêcia de contradições e desafios, desestabilizando dicotomias através das forças centrípetas e centrífugas, credenciadas por Bakhtin (In: Holquist, ed., 1981), forças essas que, de forma dialética, múltipla e simultânea, atraem e repelem em relação a um centro. Assim procedem as reflexões mais abrangentes sinalizando que as novas tecnologias representam soluções para muitos problemas e ao mesmo tempo inauguram outros conflitos na sociedade. Entretanto, os problemas sociais, aparentemente, são mais complexos e difíceis de lidar, pois envolvem mudanças de comportamento e atitude, adoção e prática de novos princípios filosóficos e novos hábitos interpretativos $^{41}$ (exs.: persuadir o outro para ter menos filhos, no caso de problemas de superpopulação e pobreza; dirigir cuidadosamente, respeitar diferenças culturais). Ao mesmo tempo, novos horizontes poderão ser expandidos através da constante aprendizagem, reaprendendo muito mais que ensinando, como base da vida e condição para customizarmos criticamente as nossas próprias experiências.

Acredito que uma melhor compreensão dos conflitos gerados global e localmente pode ser viabilizada se procedermos a uma intervenção na fluidez da modernidade. Conceito este de Bauman (2001) que aborda o homem na condição de consumidor cuja identidade é negociada nas complexas interações sociais. Tal identidade vem sendo construída nas interações dos hiperleitores da presente pesquisa, isto é, com fachadas múltiplas, fragmentos pluralizados, incoerentes e efêmeros, em meio às rápidas demandas e diferentes formas de consumo em um único ser. As interações sociais que emergem na liquidez requerem, assim, orientações para um eu descontínuo, um esforço incessante para se desdobrar num outro a todo o instante. Essa modernidade líquida abriga a vida e o mundo de forma compartimentada, mas, nem por isso desconectada. A agência humana poderá ocorrer por meio de um investimento coletivo que capacite o hiperleitor a analisar textos multimodais de forma crítica e conscientizá-lo de que ele é reconstituído socialmente pelo sistema local-global em constante processo de transformação.

\footnotetext{
${ }^{41}$ Conforme nos ensina Monte Mór (1999 e 2007).
} 
A educação para a cidadania advoga uma visão holística das relações entre o público e o privado, o político e o pessoal. Bauman (op. cit.) nos lembra que as mudanças sociais demandam maior compreensão das instituições e suas relações com os hiperleitores e grupos, bem como a revitalização da inclusão e participação ativa na vida institucional em virtude: 1) da naturalização de certas idéias veiculadas na e pela mídia, as quais competem aos intérpretes analisá-las sem que a mídia esteja isenta de responsabilidade social; 2) da crescente e intensa diversidade global que na prática requer novas abordagens para renegociar identificações e aprender a viver produtivamente com as diferenças; 3) de desafios (como os já apontados nos letramentos de Trapito, desafios cada vez maiores e Nana 27, muita coisa para fazer, pouco tempo e espaço para organizar) para a formação de hiperleitores de forma a serem mais cuidadosos em relação às formas contemporâneas de dominação, por exemplo, por meio eletrônico-digital, e, se engajar nas transformações sociais do mundo que os cercam; 4) das exigências de mercado de negócios e economia global e 5) de maior agência humana para além das meras e novas competências, habilidades, letramentos e práticas.

É dito que não há como concebermos educação sem tentativas e um primeiro possível passo é justamente assimilar, interpretativamente, como os hiperleitores compreendem o material multimodal e como eles próprios se apresentam e como são representados aos olhos do “outro”'. Não se trata, porém, de supervalorizar paradigmas “novos”, passando de uma desconstrução negativa para uma construção positiva. Com o letramento crítico, na ótica de Cervetti, Damico, Pardales (2001), enfatiza-se o cuidado de não se apoiar em mudanças unilaterais; do sentido da esquerda para a direita; da produção de informação para a produção de conhecimento e não da complementaridade e suplementaridade dessa suposta dicotomia. Afinal, não se espera adicionar elementos contingentes da história com os "velhos", conhecimentos como se fossem blocos; os resíduos historicamente contextualizados se transformam diversa e permanentemente, em meio às inovações. Sem os devidos cuidados, a tecnologia poderá reproduzir e multiplicar as divisões existentes de poder, capital cultural e riqueza global. Kellner (In: Snyder, ed. 2002:165) refuta tanto a tecnofobia (aversão às praticas sociais que requerem o uso de tecnologia) quanto a tecnofilia (participação na sociedade com o uso da tecnologia como ferramenta de interação); rejeita o determinismo, a passividade e critica as arbitrariedades, as próprias limitações que são ineludíveis à tecnologia e procura lutar ao máximo fornecendo poder e saber ao hiperleitor para que este saiba articular, se posicionar crítica e construtivamente em meio às suas leituras de mundo. A 
questão crucial, segundo o referido autor, não se reduz ao fato do computador ser bom ou não, mas, sim o que fazer com ele para tentar atingir menos desigualdade sócio-econômica e cultural, na visão de Muspratt, Luke, Freebody (1997).

Relembrando o título desta tese, Letramentos na sociedade digital: navegar é e não é preciso, reitero, uma vez mais que, articular a questão de letramentos críticos nos chama à reflexão de estudos sobre a produção e hermenêutica da suspeita (Ricoeur, 1978) no meio eletrônicodigital. Esta última vem reforçar a minha tese, Letramentos na sociedade digital: navegar é e não é preciso. Assim sendo, nada está fora do exercício de interpretação, o qual poderá ser sempre expandido por meio daquilo que Ricoeur (op.cit.) denomina de hermenêutica da suspeita. Tal conceito refere-se a uma “bússola”' diferenciada em tempos digitais. Esta oferece múltiplos caminhos de leitura online, um link abre-se para outros e muitos outros. Talvez se possa inferir que a bússola digital representa uma forma de ruptura dos conhecimentos pré-existentes por parte dos hiperleitores, ou seja, a uma transformação oriunda do processo de análise e interpretação de um referido texto. Tomemos, por exemplo, o caso de Giulia quando indica que a navegação, ao menos em sua experiência, pende para navegar não é preciso, sugerida no título desta tese. Da mesma forma, Rodgar gosta da Internet porque ainda há grande "liberdade”, registrando liberdade com aspas para não se resvalar num vale tudo, o que caracteriza sua criticidade de forma dialética. Diferente das produções culturais no papel, as incertezas que a Internet e seus usuários criam nem sempre possuem as âncoras fixadas em portos e destinos à vista, elementos característicos da navegação precisa como a de outrora.

Como dito anteriormente, Ricoeur (op. cit.) proclama a escola da suspeita, ou seja, uma reflexão que parte da premissa de que o discurso, por ser polissêmico, possibilita novas interpretações. É possível constantemente re-interpretar que o mundo e a alternativa que Giulia oferece não é senão conviver com as mudanças ( $O$ jeito é tomar cuidado...). Isso ocorre porque a presença do significado é visa como uma ilusão, pois, o signo seria uma presença numa ausência, por assim dizer; algo no lugar de uma outra coisa, e, somente existe a partir de uma perspectiva. Somos construídos por signos e discursos. A nossa identidade é também contextual. Sendo opaca, a linguagem carrega momentos de sua produção, sua dimensão local, histórica, social, política e ideológica. Nesta perspectiva, a Internet apresentase como um contexto propício a essa abertura de possibilidades de novas leituras de mundo. 
Hiperleitores como Yohane e Ampcity ao constatarem a percepção de que houve oportunidade de interações mais críticas, já constroem significados, ou seja, constatar percepções já instancia uma interpretação. Como meio que propicia a atividade mental o site http://www.webnarah.pro.br/old parece ter suscitado nesses hiperleitores a importância de opinar, debater, argumentar, pesquisar. Ampcity assinala o reconhecimento da diferença entre acesso à informação e formação crítica do cidadão: Falta agora o leitor saber ler, interpretar e debater sobre o assunto; Interpretar é preciso e informação não significa formação. Essa afirmação categórica, aparentemente, revela uma instância de ruptura e reflexão que o referido site pode ter gerado quanto à formação do cidadão crítico na sociedade contemporânea.

Ainda nessa rede de raciocínio e fazendo intertextualidade com o que foi explanado em termos de noções teóricas, Derrida (1997) um dos mentores do pós-estruturalismo, orienta para o que 'denomina' differance e suplemento, o always already isto é; o adiamento, o significado está ancorado ao significante que é sempre outro significante. $\mathrm{O}$ fato de que a realidade é construída não significa que não haja uma realidade. Derrida (op. cit.) não nega o contexto, mas, sim, chama a atenção para a idéia de que há sempre outras interpretações acerca de um mesmo texto, ou seja, de um mesmo hipertexto.

Ricouer (op.cit.) advoga que é sempre através da interpretação que o trabalho da reflexão filosófica ocorre. Estabelece uma relação entre a filosofia da linguagem (hermenêutica como filosofia) e a ciência da linguagem (semântica como ciência). A hermenêutica (teoria das regras de interpretação) compreende o signo, conforme dito anteriormente, como expressão lingüística de duplo sentido, termo utilizado pelo autor, sendo possível de ser interpretado através de uma ruptura, ou seja, uma ruptura com conhecimento mais expandido da filosofia da linguagem. Este exercício da suspeita desmistifica sentidos fixos e nega o desejo de origem, questionando a existência de uma verdade única. Dessa forma a hermenêutica crítica pode nos auxiliar na compreensão do outro, de seus sentidos em múltiplas culturas e ao mesmo tempo de si mesmo, bem como do ser de um modo geral. Vai além, afirmando que não há análise estrutural sem inteligência hermenêutica - transferência de sentido. Em decorrência, a compreensão das estruturas requer o pensar a partir dos símbolos. 
É no simbolismo que a semântica léxica apresenta-se como polissemia (multiplicidade de signos que constitui a ciência linguística); estrutura-se como um efeito de sentido produzido no interior do discurso. A interpretação baseia-se na articulação do linguístico com o não linguístico. Nesta perspectiva, a estrutura do duplo sentido revela 'a equivocidade do ser; o ser se define de múltiplas maneiras’ (op. cit.p:100). A polissemia e o simbolismo pertencem ao modus operandi da linguagem e são os lexemas (palavras) que se desenvolvem nas variações contextuais. Assim, o simbolismo ganha expressividade pela heterogeneidade entre o plano do discurso (manifestação) e o da língua (imanência). Portanto, o hiperleitor explica o símbolo partindo do discurso constitutivamente heterogêneo e não de uma linguística estrutural, uma vez que nenhum ser é uno, com origem em si mesmo. Tal heterogeneidade manifesta-se na materialidade lingüística do texto e esta visão de heterogeneidade está indissoluvelmente ligada ao sujeito e seu discurso. Discurso entendido como um evento e interpretação, enquanto apropriação, como um acontecimento (Ricoeur, 1976:99):

O texto fala de um mundo possível e de um modo possível de alguém nele se orientar. As dimensões deste mundo são propriamente abertas e descortinadas pelo texto. O discurso é, para a linguagem escrita, o equivalente da referência ostensiva para a linguagem falada. Vai além da mera função de apontar e mostrar o que já existe e, neste sentido, transcende a função da referência ostensiva, ligada à linguagem falada. Aqui, mostrar é ao mesmo tempo criar um novo modo de ser.

Nessa hora, vale a pena refletir sobre como uma maior expansão da criticidade de certos hiperleitores, mencionados no início deste capítulo, poderia ocorrer com a contribuição do próprio meio digital e da capacidade de expansão interpretativa, sugerida pela hermenêutica do referido filósofo. Se voltarmos o olhar para os dizeres dos mesmos no que tange à questão da inclusão digital, perceberemos que suas visões restringem-se ao uso direto da máquina, mas, não ao fato, por exemplo, de estarmos todos incluídos, involuntariamente, no universo regido por produções já digitalizadas: Tv, rádio, meios de transporte, por meio dos quais já podemos exercitar a suspeita no ato da interpretação dos eventos produzidos por esses meios. Uma cena de filme ou programa de televisão, uma imagem na revista e no jornal, já são produzidas por recursos tecnológicos, sugerindo leituras mutidimensionais. Não saber usar o computador, não significa que o usuário não tenha senso de criticidade em sua interpretação. 
Nota-se que é crescente o reconhecimento de que as produções midiáticas favorecem à construção de nossas imagens e compreensão do mundo. A educação, por sua vez, pode desenvolver habilidades e criticidade para que o hiperleitor sobreviva de maneira informada num ambiente de lutas, de discriminações. Esta capacidade poderá sensibilizá-lo a discernir os perigos veiculados pela mídia. Em princípio, a mídia faz uma oferta de comportamentos, valores, papéis sociais, consumismo. Os cidadãos menos atentos em geral, não conseguem se aperceber das pedagogias embutidas sublinearmente nos processos midiáticos. Estas, juntamente com várias atividades sociais, comporiam o que Giroux (2005) denomina pedagogias públicas as quais vêm influenciando a sociedade sem mesmo que esta perceba seus efeitos. O letrado familiarizado com letramentos meta-mídia, segundo minhas apreensões dos ensinamentos de Lemke (1998:283-302), poderá mais facilmente analisar os gêneros de diferentes multimídias, as convenções, códigos e estratégias que este meio utiliza; poderá desconstruir estereótipos compreendendo a tela como lugar de comunicação que engloba muito mais que o encontro de escrita e imagem; expandir a área de interpretação acerca de um determinado evento, texto, espetáculo visual, imagem, animação; beneficia-se da interação com vários temas (arte, interação multicultural, jogos eletrônicos); promove debates críticos repensando as noções de verdades como estas se apresentam numa complexa rede dinâmica que poderá ser modificada a qualquer momento; conscientizar-se de que as linguagens escrita e falada não dão conta de explicar as narrativas maleáveis online; atenta-se para o fato de que navegar é e não é preciso.

Diante do exposto, os ambientes que são multimídia requerem navegadores equipados para interpretar as interfaces com palavras, impressos materiais, imagens, composições de áudio e vídeo. Vimos até aqui que os hiperleitores dessa pesquisa compreendem esses artefatos culturais revelando a complexidade do assunto. Complexidade esta que ultrapassa a compreensão de simples formas lineares de causa e efeito sobre as implicações da tecnologia em suas práticas sociais. Como se engajar nesse meio fluido e, portanto, dinâmico, de comunicação socialmente construído, convivendo com conflitos e desafios ideológicosculturais, sem, necessariamente, recorrer a conhecimento prévio, é o assunto do próximo capítulo. 


\section{Capítulo 3}

\section{O letramento crítico e a linguagem visual na interação dos hiperleitores}

Recordo o leitor que os participantes de Webnarah utilizam o meio digital como parte integrante de seus cotidianos, trazendo epistemologias influenciadas pela aprendizagem ocasionada pela Internet. Em seus dizeres, a tecnologia comparece principalmente da perspectiva de ferramenta de trabalho, com seus efeitos na vida diária. Esses participantes salientam o quão dependente de máquinas torna-se o homem moderno. Questões sobre os possíveis efeitos tecnológicos na educação abordando o papel da imagem, som e animação podem ser expandidos nas leituras acerca de vídeo games, imagens, charges, música, filmes, por meio da expansão de letramentos apoiados em teorias como as mencionadas na fundamentação teórica no início deste trabalho.

Até aqui percebemos que em algumas categorias (imagens, emails, lendas urbanas, música) do site de pesquisa, prevaleceu a noção de tecnologia como fenômeno dos tempos modernos que os fazem interagir de forma já múltipla, para além de suas capacidades de focar em um só aspecto, conforme características dos novos letramentos apontadas por Gee (2003, 2004), Muspratt, Luke, Freebody (1997), Cope, Kalantzis (2000), Lankshear, Knobel (2005). Estes foram relacionados com os conceitos de hermenêutica crítica, na perspectiva de Ricoeur (1978) e desconstrução, sugerida por Derrida (1979). Mais do que nunca os selves que os constituem não fazem concessões à verdade única e coerente, mas, reconhecem as influências que dela sofrem. Também percebemos que esta espécie de saturação social e invasão do meio digital em suas vidas, em si, não necessariamente atraem maiores interações, haja vista que muitas de minhas perguntas não foram respondidas pelos hiperleitores, conforme expliquei anteriormente. A metade dos cadastrados sequer se interessou em debater algum assunto no site e, mesmo cadastrados, vários interagiram uma ou outra vez durante o processo de pesquisa, conquanto tenha a pesquisadora reforçado a oportunidade de participar dessa experiência através de e-mails mais personalizados. Lembramos, ainda, que a questão da inclusão ${ }^{42}$, via comunicação eletrônica, já não é mais utopia para alguns. No capítulo um,

\footnotetext{
$42 \mathrm{O}$ que é fundamental na revisão do conceito de inclusão digital é a habilidade e o conhecimento que estão em jogo ao fazermos uso das tecnologias para engajarmos em práticas sociais significativas para um determinado
} 
procurei esboçar um mapa panorâmico, pensando ser uma escolha didática. Tentei construir sentidos às perspectivas dos hiperleitores aqui pesquisados, centrando nas concepções que estes constroem no que se refere à tecnologia em geral. Reitero que tais interpretações constituem-se em espaços abertos para novas re-leituras, sendo, portanto, compreendida como uma das possíveis interpretações.

Nesta parte, recordando que a presente pesquisa é de cunho exploratório, cuja tese, Letramentos na sociedade digital: navegar é e não é preciso, estabelece que é sempre possível re-interpretar textos, questionando, assim, os sentidos já dados, procuro enfocar como os hiperleitores interpretaram a imagem da pintura de Magritte, A condição humana, (vide apêndice 2) recriada por designers gráficos de um site denominado Java.net (Magritte editing its own interface), conforme mostrada nas páginas subsequentes. Antes, porém, vale enfatizar que nos meios modernos de comunicação, o visual predomina e o verbal tem função de complemento, embora igualmente importante. Kress (2003) nos recorda que a tela digital organiza-se pela lógica da imagem por conta da profusão de composições que apelam fortemente para o aspecto visual.

Nessa seara de lógicas complexas, a maioria dos componentes textuais compreende imagens e não mais palavras como há 40 anos, de acordo com Kress (op. cit.), suscitando teorias de significados que considerem os múltiplos processos de percepção e interpretação a partir dos quais novos processos são desenvolvidos com novos formatos, reconfigurações e valores culturais. Depreende-se, assim, que o texto é sempre um produto de um trabalho e de uma prática social. Desse avanço tecnológico coincidindo com transformações econômicoculturais envereda-se para a uma nova tendência, segundo o referido autor: da escrita tornarse praticamente imagem.

E é dessa forma que estudos da imagem ganham destaque na sociedade globalizada e o ponto de partida é exatamente o status sócio-discursivo que a mesma adquiriu dada sua profusão e

contexto. Warschauer (2004:109-154) propõe a reapropriação dos conteúdos de multimídia, com a finalidade de atender às necessidades pessoais, locais e coletivas e não ao consumo passivo da comunicação mediada por sofisticadas tecnologias. 
difusão nos meios de comunicação, outrora relegada ao mundo das artes (Castells 2006). Santaella \& Nöth (2005) e Virilio (2002) estudam a imagem de perspectivas históricosemiótica e sócio-cultural, respectivamente, conforme apontado em estudos de Monte Mór (2006).

Monte Mór (op. cit.) resume com acuidade as três fases nos estudos de Santaella e Nöth: préfotográfica, fotográfica e pós-fotográfica e aponta certa correspondência e diferenças destes com os três paradigmas de Virilio: lógica formal, lógica dialética e lógica paradoxal. Na fase pré-fotográfica e na lógica formal, a imagem é construída pela criatividade e pela capacidade física que o homem exerce no espaço físico com suas mãos. Nascem desse processo artesanal, artefatos como pinturas, desenhos, esculturas, gravuras em superfícies explicitamente materializadas no concreto: papel, madeira, pedra, tais como as imagens do séc. XVIII.

Nos estudos citados, apreende-se que na era fotográfica e na lógica dialética, a industrialização no séc. XIX contribui para a produção de recursos tecnológicos que permitiriam o homem fazer inervenções dinâmicas em seu redor físico. Na televisão, nos filmes, nos vídeos, observamos a construção de sentidos mediados pelas lentes das câmeras, por exemplo, alterando intensamente o modo de explorar o meio ambiente, as paisagens de fundo e de todos os lados nas quais o evento social se constituia. A lógica que imperava era a da credibilidade dos fatos ocorridos nas notícias veiculadas em tempo real de um determinado acontecimento. O leitor acostumou-se a olhar e acreditar no fato supostamente ocorrido, pois as lentes e o cameraman não mentiam; lá estavam no local do crime, da guerra, testemunhas de uma narrativa verídica, vivida e comprovada tecnicamente.

Os paradigmas da fase pós-fotográfica e o da lógica paradoxal, segundo os autores anteriormente citados, introduziram uma mudança em que os produtos se conjugam com processos em vitrines digitais em permanente transe, por assim dizer. É o séc. XX num contexto em que imagens holográficas e as imagens geradas pelo computador desestabilizam conceitos de tempo e espaço concretos e reais. Há um deslocamento constante entre o espaço real do objeto construído e o tempo real desse tipo de imagem. A computação mescla o tempo em que a imagem é construída e o tempo em que esta é apresentada, difundida, multiplicada, 
permanentemente. A incerteza da distinção entre tempo-espaço real e virtual se instala e rompe com noções de autoria, poder de construções de significados no mundo virtual.

O que interessa ressaltar na visão de Monte Mór (op. cit.) é o fato de que uma lógica não elimina as outras; ao longo dos anos o homem desenvolveu uma maneira complexa de ver o mundo, levando em consideração a multiplicidade e simultaneidade das percepções que os novos contextos suscitaram. Saliento a minha concordância com a referida autora no que se refere à natureza dinâmica e sumultânea das fases acima explanadas. Essas fases não são independentes entre si, pois, o que ocorre são transformações das mesmas num contínuo lógico em que resíduos culturais de um paradigma para outro continuam influenciando e dando sustentação à capacidade que a própria sociedade tem de gerar novos conhecimentos e experiências humanas.

Nossas experiências iniciais no mundo nos revelam que organizamos nossos prazeres, medos e necessidades com base naquilo que vemos, olhamos, visualizamos, contemplamos, observamos, descobrimos, reconhecemos, percebemos, examinamos. O amplo espectro de processos compõe uma ordenação não linear em que novas práticas de identificações de participantes em grupo ressurgem. As práticas sociais, no meio eletrônico-digital por si só, já constroem dinamicamente uma metodologia reconectada à prática do cotidiano de tais participantes. Novas relações entre as múltiplas localizações temporárias (locus de enunciação) nas quais os participantes se engajam culturalmente constituem, agora, o foco de abordagens metodológicas capazes de nos transformar em indivíduos visualmente letrados, avançando para além da mera utilidade e estética da imagem. A educação visual que se implantou nas escolas de forma geral, parece ter cumprido de forma avassaladora a função de depositário de recreação, de engessamento intelectual e uma situação parecida se espalha no uso de outros meios: cinema, televisão e agora, Internet, deixados ao sabor da intuição e do mero acaso.

A gramática visual existe e é sustentada por um conjunto de técnicas e regras básicas, convencionais, manipulativas que podem ser aprendidas por estudiosos dos meios de comunicação, diferente do passado, domínio exclusivo de artistas e designers. A sintaxe da gramática convencional é relativamente estável, pois prevê uma relação entre os elementos 
pré-estabelecidos. Já na sintaxe da imagem novas formas de relação de poder favorecem a abertura de novos trabalhos e escolhas que não mais coincidem com a trilha linear das leituras da escrita tradicional. Segundo Dondis (2000:13), quase tudo que vemos, sabemos, compramos e cremos é determinado pela profusão de imagens e pelo domínio que as mesmas exercem sobre nossa psiquê. A percepção e formação de imagens mentais vêm embaladas por condicionamentos culturais complexos que afetam a maneira com a qual compreendemos e encaramos o mundo. Aprendemos a confiar em nossos “olhos", deles dependemos o tempo todo e por esta razão, suspeitamos deles próprios. É um fenômeno que certamente se intensificará e, portanto, enfatiza-se a necessidade de domínio sensível dos componentes visuais, seus efeitos colaterais, enfim, uma investigação do processo de percepção variada e simultânea de elementos que compõem o todo de uma obra e/ou evento: pontos, linhas, formas, direções, cores, texturas, dimensões e movimentos. A referida autora vai além, advogando a favor das teorias de Castell, Luke e MacLennan (1989:70), quando estes pensam que possíveis saídas para a crise do letramento devem ter como ponto de partida a aquisição e uso de letramentos que somente uma revisão histórica, social, linguística e psicológica podem esclarecer. Revisão esta que parte do princípio de que cada meio de produção de significados sugere especificidades que lhe são próprios, mas essas singularidades são resultados dos resíduos culturais dos meios que o antecedem. Dito de outra forma, não há como dissociar o contexto social e, portanto, o locus de enunciação do intérprete da imagem, de análise e reflexão. Nas escolas a revisão de letramento deveria trabalhar as leituras de forma participativa, abrindo portas para reavaliações e modificações no meio social, pois constata haver uma discrepância significativa entre o que se considera letramento nas escolas em geral, e o que se constitue como habilidades úteis na sociedade (op. cit: 7).

A imagem compreendida por Manovich (2001) e Burnett (2005: xviii) opera em contextos específicos, nos quais legitima o fato de que formas de inteligência estão sendo programadas nos recursos tecnológicos e na mídia que usam a imagem como umas das mais importantes ferramentas que responde pela sofisticação e complexidade desta relação, tanto na textura, nos detalhes, no conteúdo, como principalmente no que se refere às possibilidades de uso, do que se pode e não se pode realizar com a tela. Esses autores, acima citados, revitalizam, portanto, a idéia de que em todo lugar a existência da imagem extrapola a noção convencional de que ela é apenas objeto para contemplação, apreciação, mera informação. 
Latour (Apud Burnett, 2005:xix) explica a imagem do ponto de vista de uma forma de acesso às diferentes e várias experiências; é a interface que estrutura a interação entre os hiperleitores e os ambientes que compartilham. Em decorrência, a fronteira entre inteligências humana e tecnológica comparece tênuamente. Muito mais que simples necessidade, essa associação expande-se entre o corpo e a mente, da perspectiva cultural. Os processos mentais podem ser traduzidos em metáfora: corpo como informação já que o mesmo autor não admite uma separação científica entre corpo e mente. Imagens internas e externas se interagem, análogo ao pensamento e linguagem, fundamentalmente, inseparáveis do sujeito falante. Isso significa que o poder da experiência da visualização faz com que cada intérprete da imagem a sinta e emocione de uma forma diferente e única. As barreiras que distinguem as imagens dos humanos podem ser subvertidas, pois reagimos física e perceptivamente à luz e ao escuro através de estados psicológicos e culturais. O modo como encaramos o que vemos e não vemos é afetado pelos nossos costumes sociais. Burnett (op. cit.: 64) expande essa idéia citando a visita a um museu, como exemplo. Se o visitante do Vietnam Memorial em Washington conheceu veteranos da guerra, ou foi um ativista anti-guerra, sua interação com memórias, imagens, histórias constituem parte de um processo generativo; o visitante, nessas condições, faz com que as fotos e memórias da guerra do Vietnã funcionem para ele, de uma certa perspectiva, e isso torna-se um exemplo da intensidade (corporal, mental) com a qual o processo estrutura a visualização e se relaciona com a experiência e o conhecimento. Analogamente, nem todas as modalidades oferecidas no site de pesquisa foram acessadas por todos os hiperleitores. Estes, aparentemente, compartilham da idéia de que as seleções são influenciadas pelos valores sócio-culturais de seus contextos.

No mundo virtual, como nas experiências vividas, as imagens, visões, pensamentos e reflexões não estão em lugar algum e ao mesmo tempo estão em todos os lugares, pois todos esses elementos são mediados pela linguagem e esta é incompleta e dinâmica. Somente quando construímos sentidos e os contextualizamos é que esboçamos algum lugar, lugar este constantemente passível de deslocamentos quando do momento de renovação das interpretações. Isso descontroi concepções convencionais e rígidas acerca da subjetividade. O resultado da experiência (ex.: vídeo game que será explorado no próximo capítulo) advém daquilo que Burnett (op. cit: xx, 70-90) denomina de espaço do meio. É o espaço que mescla o virtual e o real numa atmosfera de visualização que produz novas formas de trocas e interações graças às escolhas criativas de quem articula nesse espaço altamente sofisticado. A 
esse conceito Castells (2006) denomina virtualidade real. O termo virtual foi usado, segundo o autor mencionado, nos estudos de ótica no início do séc. XVIII para descrever a imagem refletida e refratada de um objeto (Wooley, 1992, in: Burnett, op. cit.: 83). A imagem refletida e refratada não é o objeto em si, mas, parte de um contínuo que mistura imagens, objeto e sujeitos, formando uma composição contextual. O virtual, assim compreendido, não demanda a existência direta do objeto. O que enriquece a concepção de espaço do meio é justamente o potencial que seu interstício fornece: estender o poder da imaginação para viabilizar novas perspectivas numa atmosfera híbrida. Para exemplificar o real/virtual, Burnett (op. cit.: 55) descreve, como sendo análoga a relação entre admiração e rejeição que um fã tem pelo seu ídolo. Ao ver a celebridade, a multidão se consome em gritarias e essa fascinação é produto dos excessos imagéticos do evento, do investimento energético para levar o fã a crer que as músicas, as imagens, o corpo do ídolo são reapropriados para si. E dessa energia despendida, ocorre também uma forma de agressão, explosão de fantasias, sonhos. No limite, é melhor ter uma representação mínima da pessoa, roupas, maquiagens, a não ter nada, como se houvesse necessidade de dar vida às fantasias, torná-las reais, porém, até o ponto em que não afetem o ideal da pessoa admirada ou a rotina de quem a admira. No site de pesquisa, Webnarah.pro.br/old, por exemplo, nem todas as modalidades oferecidas foram acessadas pelos hiperleitores, reforçando a influência que suas lentes culturais exercem sobre as escolhas.

Como fenômeno, a imagem integra e desintegra diferentes manifestações culturais, redefinindo constantemente a relação homem-computador e seus efeitos na prática. Nessa acepção, nenhuma imagem pode ser divorciada de seu contexto social de uso e aplicação, tampouco de sua mediação tecnológica específica. As pesquisas aqui realizadas sinalizam que, como na Internet, são justamente nos espaços híbridos, plurais, simultâneos e dinâmicos, entendidos como processo interpretativo, que os expectadores adquirem flexibilidade e desenvolvem o olhar crítico, conforme postula Ricouer (op. cit.), para lidar com a multiplicidade e simultaneidade de interações constitutivamente discursivas, com as quais eles lutam para sobreviver.

Assim sendo, os eventos não são interpretados na relação binária espectador e imagem, mas, sim no ponto de articulação entre discursos complexos por meio dos quais os sentidos interpretativos se constituem. As imagens são menores, por assim dizer, que os eventos. $\mathrm{O}$ 
desafio é compreendê-las, questionando suas ideologias, levando-se em consideração que o campo visual, os artifícios tecnológicos dinamizam a linguagem para além da mera representação da suposta realidade. O evento é processado por uma experiência pessoal, emocional, cultural e, por esse motivo, tal mapeamento mental é indiscutivelmente sóciocultural. A riqueza do processo visual-discursivo dependerá da tensão entre distância e proximidade que move o hiperleitor para uma espécie de imersão e submersão (entrar na tela e desta participar ativamente), associando pontos de convergência e divergência, de dentro para fora e vice-versa, com os contextos culturais nos quais a imagem e intérprete se inserem. O trabalho da memória e mente, contemporizam narrativas socialmente compartilhadas, sem que o intérprete esteja necessariamente no local em que as mesmas ocorreram ou ocorrem, isto é, procede-se a uma experiência virtual-real, única a cada momento. A imagem seguinte introduz uma atividade de interação criada para o site de pesquisa. 


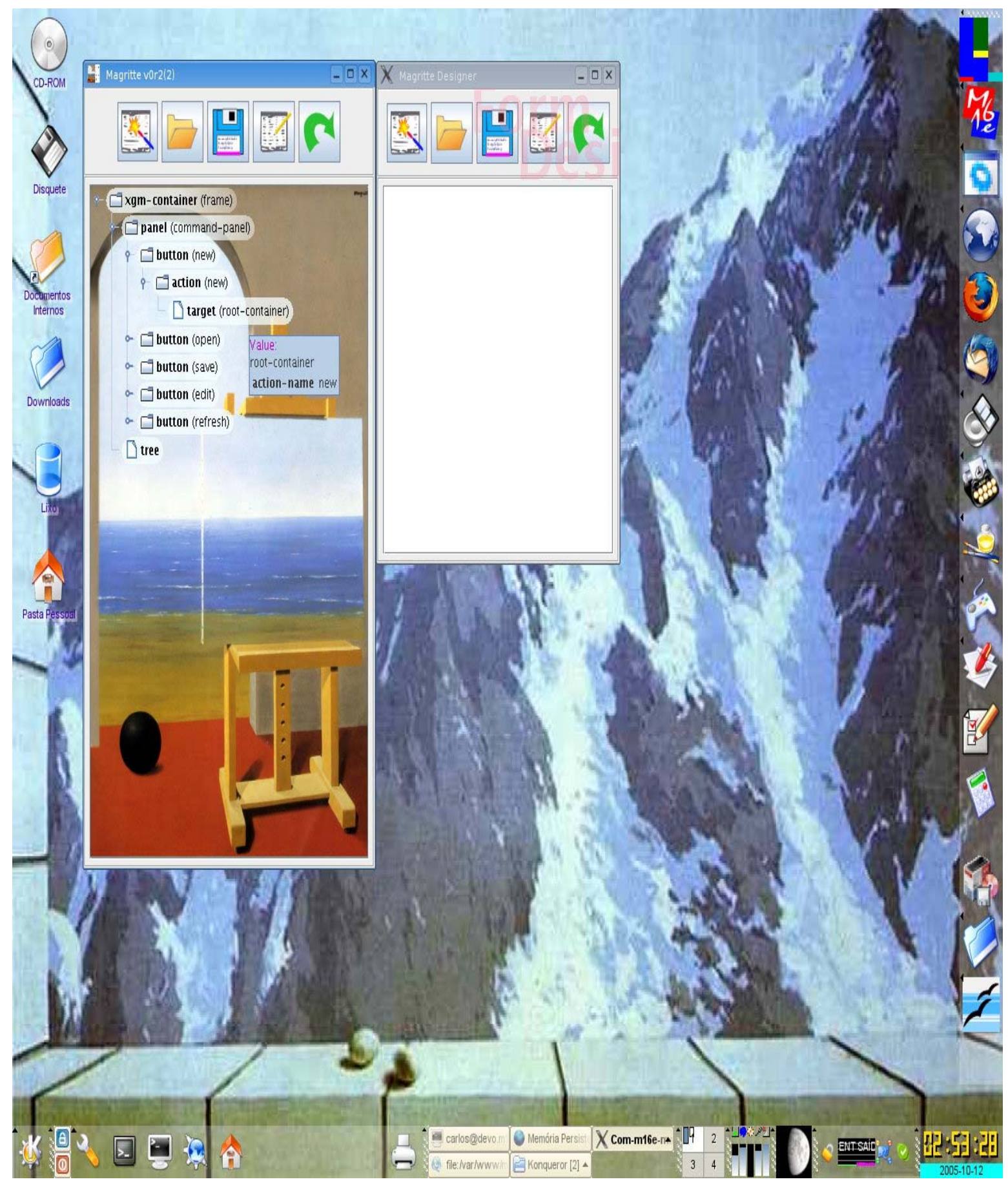

\section{Magritte}

Cyberbob: O que esta imagem lhe sugere?

Comente: 


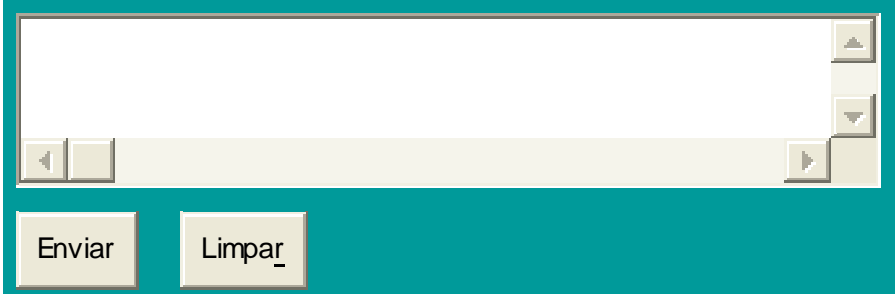

Temas Anteriores:

- De olho nas galerias

- Fotos do home

- Frase de caminhão

- Magritte

- Babe

- Vou de férias para as praias

\section{Comentários:}

\section{Trapito}

Anos modernos. A atualidade..informática, projetos, ferramentas, contatos, várias tarefas ao mesmo tempo. E..desafios cada vez maiores para conciliar tudo rumo ao topo da montanha, sem 'pirar' (lê-se, não conseguir subir a montanha ou após chegar ao topo, cair no precipício).

\section{Sweet_Girl}

Bem honestamente, sugere uma tela de computador com uma linda área de trabalho (montanhas) e o quão dependente somos dos computadores e da tecnologia!

\section{nana27}

Achei uma imagem muito carregada, muita coisa misturada, apesar de não estarem amontoadas, passa uma sensação de bagunça, mal organização e falta de espaço, 


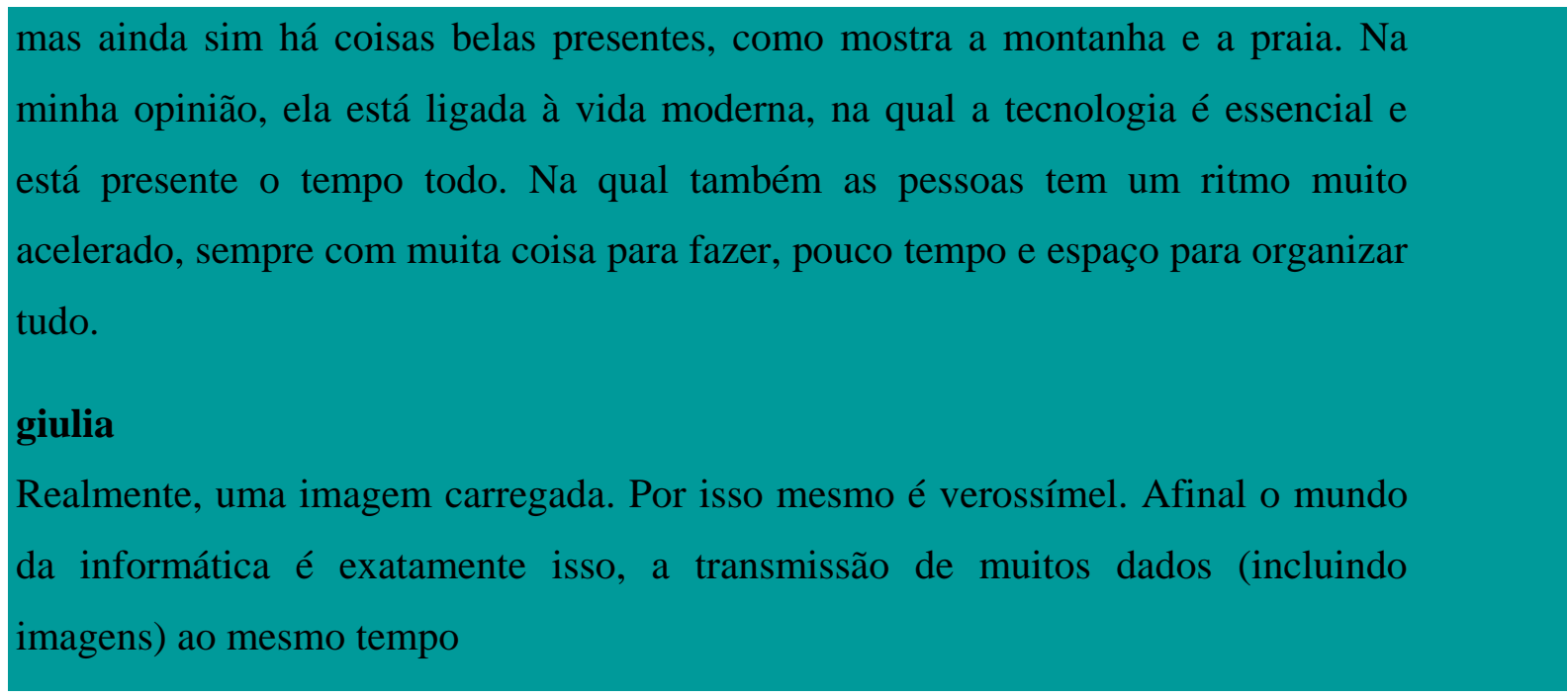

Essa pintura é uma referência à obra de Magritte. Da forma em que está exposta, continua sendo arte, mas divide sua autoria com os peritos em computação gráfica. Estes, embora não sejam artistas do ponto de vista convencional, tornam a imagem mais complexa. Mais que simples objeto de contemplação, a referida pintura se legitima como uma instituição na medida em que reafirma, incessantemente, o desenvolvimento de uma vocação para reflexão mais crítica abrindo, assim, espaços para interação sócio-ideológica entre o homem e a máquina. O homem visto como tradutor e articulador cultural e a máquina como uma extensão de poder num espaço tri-dimensional de hipertextos, capaz de simular realidades mais interativas. Nessa relação dialética e, portanto, dialógica, o homem realiza intervenções na máquina, ao mesmo tempo em que aprende com ela as novas pistas e demandas de transformações, desbancando a soberania da relação sujeito-objeto que, agora, tanto sujeito, como máquinas, são igualmente dinâmicos.

De volta ao contexto analítico da presente tese, verificamos que as reflexões dos hiperleitores de Webnarah referem-se ao computador como um bem cultural palatável. Entretanto eles deixam entrever que, o que lhes parecia próximo e familiar revelou-se desconhecido, do ponto de vista imagético. Retomando a categoria, imagens, propus que tecessem idéias sobre $A$ condição humana, sem informá-los que fora recriada por designers. O motivo pelo qual recorri a esta decisão está atrelado ao caráter multifacetado e a predisposição de Cyberbob, estimulados pelo meio digital, para brincar de Deus dito por Rodgar se referindo aos vídeo games (vide apêndice 12): 
Talvez porque seja interessante viver outra vida (a virtual), pois tem-se assim mais oportunidades de se viver como queira, talvez de encontrar liberdade que muitas vezes não temos na chamada "realidade". Todos gostam de brincar de Deus, criar e comandar um indivíduo, e o pior é que acabamos por acreditar muito nisso.

Tendo esse contexto em perspectiva, a imagem é parte da mente humana, de todo o processo de sentir e pensar, tal qual é a linguagem (Dondis, 2000). As demandas de ver, olhar e pensar sobre a obra iniciada por Magritte e que se permitiu ser recriada, por exemplo, bem como torná-la significativa, são multifacetadas e requerem renovadas práticas de interpretação. O objeto pode até existir independente de seu intérprete, porém as imagens que dele suscita jamais são independentes do processo de interação. Do contrário, como a imagem e o sonho poderiam existir sem serem vistos, sem o visualizador e o sonhador? Deverá haver, sim, uma predisposição para o imprevisível, para uma aventura deveras complexa. O fato de sermos constituídos na e pela linguagem faz com que nossas leituras se engajem em meio a uma multiplicidade de subjetividades e manifestações sociais, por vezes, historicamente temporais e contraditórias.

O evento, - pintura de Magritte e de outros -, é compreendido sob o processo de aprendizagem e descoberta que Nana27 sugere:

Achei a imagem muito carregada, muita coisa misturada, apesar de não estarem amontoadas, passa uma sensação de bagunça, mal organização e falta de espaço, mas ainda assim há coisas belas presentes, como mostra a montanha e a praia. Na minha opinião, ela está ligada à vida moderna, na qual a tecnologia é essencial e está presente o tempo todo. $\mathrm{Na}$ qual também as pessoas tem um ritmo acelerado, sempre com muita coisa para fazer, pouco tempo e espaço para organizar tudo.

Na sua hiperleitura, a ambigüidade está presente; apesar do amontoado de coisas, da bagunça, o ritmo acelerado se apropria da beleza da paisagem e da natureza. Essa percepção vai pondo em curso os interstícios que tencionam sua experiência de vida social e a familiaridade com o cenário. Aparentemente, Nana27 leva as suas percepções da sociedade atual para a construção 
de sentidos da referida imagem: conciliação de excesso de trabalho e escassez de tempoespaço.

Para Trapito, sua trajetória culmina no topo da montanha, metáfora que, no limite, exprime a iminência do perigo, mas, também do sucesso; anos modernos.

A atualidade...informática, projetos, ferramentas, contatos, várias tarefas ao mesmo tempo. E...desafios cada vez maiores para conciliar tudo rumo ao topo da montanha,. Sem "pirar"' (lê-se não conseguir subir a montanha ou após chegar ao topo, cair no precipício).

Do ponto de vista da crítica defendida por Cervetti, Pardales e Damico (2001), tal hiperleitor apresenta um viés típico do pensamento linear. Pensamento este que acredita na "'evolução" gradual, com estágios independentes e na idéia de ascenção e sucesso com uma trajetória linear, de cima para baixo. A respeito da não linearidade do pensamento, Morin (2001) sugere que a existência de processos auto-reguladores permite que os efeitos atuem sobre as causas, como no sistema de aquecimento em que o termostato regula o andamento do aquecedor. $\mathrm{Na}$ interpretação de Trapito, a ideia de sucesso apresenta-se bem influenciada pelos valores culturais que privilegiam progressos, promoções e carreiras nos diversos setores da produção humana.

Observam-se alguns processos tradutórios em que a visão e a imagens são co-dependentes nas várias maneiras de visualização e verbalização culturais. Reduzir a imagem à tela é isso que a máquina, em princípio, realiza. No entanto, há necessidade de simular a experiência de estar com ela no mundo mediante uma perspectiva contextual, pois as imagens também dependem de um consenso partilhado pelos espectadores, de uma gama de convenções culturais que as estruturam (códigos predominantemente ocidentais, que governam a sua organização geral, cores, tamanhos, material, disposição de objetos) e tornam o mundo possível. A narrativa do evento não é a composição imagética em si como demonstram os quatro hiperleitores. O acontecimento é mediado por tudo, desde a escolha do meio em que é hospedado, pela forma com que é produzido, até a imaginação e trabalho de reflexão do intérprete. 
Trapito sugere uma participação frente a essa jornada, deixando entender que ele tem um lugar na tela, ligação estreita com a realidade de seu ambiente, ou seja, a lacuna se preenche com traços significativos a partir de sua narrativa, a qual expande sentidos que não estão “presentes”' na imagem; dialoga a partir de sua experiência da vida diária e da sua percepção de ser social que sofre as influências do meio digital. Redesenhando seu percurso, imaginamos, sem forçar a mente, o deslocamento de sua posição frente ao computador, alçando vôo para fora da janela e se deparando com a imensidão de seu próprio ato criativo ("sem pirar’'), mas que prevê as chances de uma reta final com riscos a correr. Ideologicamente, isso remete a uma preocupação com a meta a ser alcançada e com o equilíbrio, característica de epistemologia modernista. Sua mente revestida de metáforas e metonímias (o conflito entre homem e suas invenções, sem possibilidade de desfazer essa convivência, podendo, quando muito, modificá-la) constrói significados necessariamente de forma tridimencional. Mas essa tentativa de repetir a trajetória da mente de Trapito não apraz, pois é apenas a minha interpretação de sua leitura da obra artística e artisticamente tecnológica, que se transformou numa apreensão, provavelmente diferente do que ele tinha em mente e que está sujeita às novas releituras dos que lêem esta pesquisa.

De acordo com Kress , van Leeuween (1996) há uma gramática de design visual, segundo a qual, as estruturas visuais representam padrões de experiências que capacitam os seres a construir um imaginário que ocorre dentro e ao redor deles próprios. Tais estruturas constróem significados que apontam para diferentes interpretações de experiências e diversas formas de interação social. O topo da montanha na imagem interpretada para muitos converge para o céu, o paraíso dos idealismos, distante do terreno conturbado. Tal interpretação seria o produto de resíduos culturais que também constituem as identificações dos hiperleitores.

Ainda sobre a linguagem visual, esta obedece a uma gramática que permite rupturas das regras como meio de possibilidade de continuação das mudanças. Em virtude do letramento visual se encontrar nas pesquisas de instituições acadêmicas e, portanto, na esfera pública vale a pena contemplar um tratamento diferenciado às imagens com estatuto de estratégia de sobrevivência. Isto significa dizer que esse tipo de estudo ultrapassa as convenções ocidentais da escrita (da direita para a esquerda, de cima para baixo, do centro para a margem) assumindo, assim, outras dimensões culturais no ato da interpretação. 
Sweet-Girl naturaliza o campo lexical virtual, área de trabalho, imagem carregada, revelando sua cultura ocidental. Luke (In: Cope e Kalantzis, 2000:84) nos alerta que o léxico, os ícones, e o mecanismo de leitura no texto virtual seguem o padrão ocidental do livro: a direção do olhar na tela é da esquerda para a direita e o rolamento para a mudança de páginas, como ocorre em "Magritte”, é de cima para baixo. Os ícones na tela, na interface, requerem a leitura multimodal sim, lembrando, entretanto, que em várias culturas não ocidentais as construções são realizadas tendo o lixo como matéria prima, enquanto que na nossa cultura, a lixeira representa, além do descarte de arquivos e textos, a noção de sobra, excesso de riqueza. Essa combinação de ícones, inventário lexical, pasta e subpastas na lateral direta e linearidade da escrita visual que foram adaptados ao mundo virtual do computador, sugere fortemente novas formas de imperialismo cultural. Analogamente, o ícone da paleta com o pincel, e o da pasta pessoal com um desenho de casa, nos remete à civilização ocidental em que o concreto e sua relação com a natureza (casa, parede, janela, chão que sustenta a esfera negra, rack, computador se estendem para a areia, mar e montanha a céu aberto) é produto da tecnologia do homem dito civilizado, racional e moderno que se preocupa com o seu bem estar e conforto.

Percebe-se também que a tela do pintor e do designer faz sua oferta, como num anúncio de propaganda, apoiado em intensos apelos sensoriais (saturação de cores, modulação do céu, mar, montanha, casa, computador, que espelham resquícios da cultura predominantemente ocidental). Os designers propõem que mãos invisíveis de alguém que está de fora são sutilmente sugeridas à frente da tela, como que tocando o mouse para abrir espaço às novas leituras, as quais não se encerram aí. Essas mãos revelam muito sobre os possíveis hiperleitores: educador, executivo, estudante, analista, curador, enfim, que sentado a sua mesa pode sugerir uma dose de transdisciplinaridade para as descobertas mais simbólicas (Barthes, 1982) desse exercício mental. Segundo esse autor, as descobertas simbólicas são aquelas em que os significados são atribuídos ao objeto de estudo; produto de uma reflexão mais expandida com conhecimento, ultrapassando, assim, as dimensões literais, ou seja, o reconhecimento dos elementos gerais que compõem a obra. Se a máquina exerce poder sobre nós, podemos ativar saberes, nosso conhecimento de mundo e assim, construir outros significados e interpretações diferentes daqueles dados. Mesmo o olhar desinteressado se exaure diante de mera contemplação. Mesmo não dominando a língua portuguesa, relações visualmente interativas se estabeleceriam, por meio do caráter enigmático e das experiências 
multimodais (ex.: o conhecimento de que há um computador, uma montanha e casa na imagem toda). Estas cada vez mais se estendem às demandas de novos mercados, de novos espaços públicos (a exemplo do que acontece em alguns aeroportos internacionais, sustentando orientações com base em imagens, dependendo do intérprete) em que outrora seria exclusivo da linguagem vista apenas como fenômeno escrito ou oral.

Embora cada hiperleitor seja produto de sua própria cultura e, portanto, de seu locus de enunciação, nem sempre as expansões de olhar crítico ocorrem de forma natural. O que tais hiperleitores apresentaram está circunscrito a uma escola filosófica cujas assunções ontológicas e epistemológicas refletem mais da leitura crítica do que de um letramento crítico, segundo teorias aqui apresentadas (vide tabela no capítulo 1). A predisposição para questionar a composição imagética, do ponto de vista ideológico-cultural, fica sugerido sublinarmente. Tais hiperleitores não estão simplesmente preenchendo lacunas, pois, assumem a relevância do assunto coletivamente, não somente de fórum pessoal. Ao dialogarem com a imagem e com os outros, ainda que indiretamente, eles constroem tensões, compondo o pensamento não linear o qual convive com o belo da área de trabalho, da sociedade e do conflito gerado por estas novas criações na sociedade moderna. Nesse momento a navegação tende mais para a imprecisão que para a precisão, remetendo à sugestão do título da presente tese: Letramentos na sociedade: navegar é e não é preciso, instanciados pelos pressupostos do letramento crítico, na concepção de Cervetti \& Pardales \& Damico (2001). Para uma hermenêutica da suspeita e para o letramento crítico, a obra final apenas privilegia o sistema ocidental de leitura, conforme atestei anteriormente. Tal obra artística não compartilha espaço com outras formas culturais, ou seja, para uma designer oriental ou indígena, haveria apenas possibilidades destes aprenderem sobre a visão ocidental e não de ensinar a respeito de suas próprias culturas em que nem sempre o centro da visão abrange espaços de cima para baixo ou do centro para as periferias, como sugere a imagem em estudo. Apesar dos mecanismos de deslocamento de imagens, a estrutura que predomina na composição imagética congela a hierarquia sócio-cultural, metaforizada pelo topo da montanha. É nesse momento que reforço a tese de que, navegar é e não é preciso, pois o meio digital possibilita a construção de conhecimento em meio a coexistência de recursos numa velocidade vertiginos, outrora impossível. E, por meio da hermenêutica da suspeita, outros valores culturais até então escondidos poderão ser acessados mediante uma construção de sentidos. Em decorrência, o espaço da Internet propicia essas oportunidades para novas construções de significados. 
Assim sendo, estudar textos, imagens, significa desenvolver uma pré-disposição para se aventurar numa jornada não linear em que o pensamento se vê obrigado a negociar intrincadas relações de verdade, poder e manipulações midiáticas agenciadas pelas diferentes formas de linguagem e tecnologias. As discussões em torno dos estudos das imagens contam com o conhecimento de história da arte, semiótica visual, teorias sociológicas, antropológicas, psicológicas e cognitivas, dentre outras áreas. Entretanto, isso ainda é insuficiente. A multiplicidade de materiais de leitura visual, agora, no meio digital coteja práticas que dependem da natureza, da estrutura e aspirações de determinada sociedade em contextos históricos específicos.

O contexto imagético, como todo contexto, não é autônomo. Sua semântica se engendra num processo particularmente polissêmico; ela se abre para mensagens e interpretações infindáveis, porém inescapáveis à contextualização. Uma imagem pode redundar, ilustrar, complementar, surpreender e até contradizer o texto escrito que a acompanha (Santaella e Nöth, 1977:54-55) como costuma ocorrer principalmente no universo midiático. Basta que haja um signo (palavra, imagem, som) para que o contexto exista. Sendo assim, o contexto da imagem não precisa ser necessariamente verbal. No caso do canvas de Magritte, sua tela já funciona como contexto de sua imagem.

A gramática da imagem pode assumir várias funções, dada a sua constituição plástica, derivada de computação gráfica com espantosas manipulações não somente de imagens, bem como de letras, palavras, configurações do computador que aumentam as possibilidades de escolhas (ex.: tamanho e estilo de letras), luz, cores e animações. Assiste-se assim à exploração da linguagem híbrida, multiforme nas interfaces e interstícios do verbal e do visual que toma corpo, mas, está sujeito à dissolução na simultaneidade do espaço e tempo pósdigitais.

O tempo da fatura da tela como imagem eletrônica e escaneada é marcado pela instantaneidade dos clicks de quem opera o scanner, dos pixels ${ }^{43}$ não expostos à erosão do

\footnotetext{
${ }^{43}$ Espécie de ponto ou unidade gráfica mínima da imagem matriz com diferentes cores a cada vez que se manifesta na tela.
} 
tempo. É diferente do tempo em que o pintor concebe a obra, terminado o seu trabalho. A pintura convencional está sujeita à intervenção do tempo físico, envelhecida e desgastada pela transformação do tempo.

A imagem na era pós-fotográfica, termo de Santalella \& Nöth (1977:95), sugere um trinômio; cérebro, programa e expressão sensível que não remete a outra coisa senão à própria especificidade de seu caráter sígnico. Explicando: é dessa evanescência, dissolvência e puro devir irremediável, ou seja, anti-matéria luminescente que é feita a imagem eletrônica. Ela se distancia de referencialidades ou registros concretos para se aproximar da sonoridade, das simulações produzidas pelo cérebro e mediadas numericamente. Parafraseando Machado (Apud Santaella e Nöth, 1977: 94), não existe uma imagem na tela em cada fração de tempo, o que existe de fato é um pixel que corresponde a um ponto singular de informação de luz, capaz de resistir a sua própria morte, pois, o signo, além de produzir imagens sintéticas, infográficas, é, de certa forma, indestrutível.

De acordo com os autores acima mencionados, percebe-se que o signo pré-existe ao pixel, já que não é possível concebê-lo como origem em si tampouco como um fim que nele se encerra. O que de fato ocorre é um processo sígnico em que o trabalho de atribuição de sentidos ao signo se revitaliza constantemente. Na era digital, a vida de um objeto construído no interior da tela poderá ter seus dias contados. Este poderá vir a ser modificado independente dos propósitos de seus autores e daqueles que o hospedam.

Assim como a computação altera a nossa apreensão da “'realidade’, tal apreensão motiva novas maneiras de interpretação, de intervenção dos nossos olhares. As imagens duplicam e multiplicam o real, sem que o abandone, antes o transforma, de forma demasiadamente ambígua, múltipla e continuamente dinâmica. Conforme atestam Santalella e Nöth (op. cit), muito do que a máquina fotográfica faz, o homem da caverna, há cerca de trinta mil anos, já havia inaugurado com seus impressos na pedra; reprodução imagética de sua realidade, espécie de consciência latente, nas palavras desses autores, de linguagem como mediação entre ele e seu mundo. Essa informação visual constitui-se no registro mais antigo da história humana deixando como legado a necessidade de um novo enfoque sobre a experiência visual de quem visualiza a sociedade e reage à mesma. A existência da revelação da foto também 
opera sob uma das mais perturbadoras contradições: num primeiro momento o processo de revelação ocorre em meio à ausência de luz para, então, obter a imagem fotografada (1977:128-129). A questão que nos interessa de perto é o fato de que toda mudança no modo de produção de imagens provoca inevitavelmente mudanças em como percebemos o mundo. Este continua provando que os algoritmos, além da eletricidade, sustentam a manifestação sensível da imagem na tela do computador.

Oportuno é discorrer a respeito do processo de produção de imagens computadorizadas, lembrando, entretanto, que Santaella e Nöth (op. cit.) acabam por descrever a imagem como uma substância e não como um processo dinâmico, uma interação. Ao partirem do princípio de que a verdade é um substantivo conceptualizam a imagem como sendo uma concretude fixa. O computador opera sobre um substrato simbólico: a informação. A imagem é uma realidade numérica composta por pixels. Essa matriz de números na memória do computador permite que a imagem seja sintetizada, penetrável e constantemente transformada “'oscilando entre a imagem que se atualiza no vídeo e a imagem virtual ou conjunto infinito de imagens potenciais calculáveis pelo computador. Na perspectiva dos citados autores, o processo envolve: 1) a construção de um modelo de objeto numa matriz de números realizada pelo programador; 2) tal matriz deve ser transformada seguindo instruções e modelos matemáticos de algorítimos (os quais são abstrações manipuladas com combinações infinitas, réplicas do “'real”) de simulação (experimentação simbólica dos modelos) de imagens; 3) resta, então, a tarefa do computador traduzir essa matriz em pixels para tornar o objeto visualizado, na tela de vídeo. O que diferencia as imagens sintéticas de outras é que estas podem fazer experiências em espaço e tempo distintos daquela do objeto “original”, “real”, por meio de cálculos executados reiterativamente. Seu produtor gera cálculos de sorte a intervir, agir sobre o “real”, pela mediação das interações matemáticas, produzindo substratos simbólicos, ícones, imagens, simulações sob o signo das metamorfoses.

O que preside a formação da imagem virtual, portanto, é a abstração de cálculos, resultado de pensamento lógico experimental. Tal imagem fica disponível nos terminais de computador, adquire sentido por contaminação, comutação, relação com o seu intérprete cuja interatividade é iniciável a qualquer tempo. Nada concreto preexiste à imagem. Seu ponto de partida é uma abstração que simula e manipula a “realidade”, recria a realidade virtual autônoma. O que importa na infografia são os comportamentos dos objetos, as infindáveis simulações. 
O reconhecimento de que os recursos tecnológicos alargaram a capacidade humana de intervir na produção imagética, revoluciona os conceitos convencionais de fotografia e seus efeitos. $\mathrm{Na}$ era digital, com maior visibilidade no século XX, o agente participa de forma interativa por meio de novos rearranjos imagéticos, novos discursos, construindo, assim, novos significados outrora impossíveis sem tais recursos. É nesse sentido de apreensão de uma virtualidade real, com alto grau de performatividade do hiperleitor, terceira fase compreendida por Virilio (op. cit.), que suspendemos localizações fixas de focos imagéticos para lançar aberturas interpretativas e ainda, a constante possibilidade de transformar o que o próprio autor-hiperleitor já mudou.

Em decorrência, nesse novo ambiente maleável de fluxo interativo, somos levados a crer que as assertivas e o que é tido como falsificações são produtos da capacidade críticointerpretativa do espectador que constrói significados a partir de seu locus de enunciação, com uma multiplicidade de formas para desestabilizar o terreno, supostamente sólido, de tempo e espaço reais. A tecnologia permite a constante reconstrução criativa e estratégica desse terreno em ilusórios tempos e espaços, em combinações diversas que não dependem da reificação do objeto “'original”', manualmente produzido.

No que tange às demandas atuais da sociedade em rede, apreende-se a relevância do hiperleitor (como Trapito, Nana27, Sweet-Girl e outros) participante da criação e manutenção da sua agência na tela digital, cada vez mais, expandir suas habilidades com as novas ferramentas no âmbito tecnológico, e, principalmente, ampliar o seu exercício hemenêutico cotidiano. Evidencia-se, assim, a tese de que a Internet é o espaço mais propriamente adequado no qual o hiperleitor poderá expandir suas capacidades de execução e reflexão de seus próprios letramentos.

Eis, assim, a fundamentação das imagens sintéticas, porta de acesso ao mundo virtual. Mas se a capacidade do computador preenche desejos com cargas estéticas, éticas longe de serem neutras, é exatamente em sua decolagem que desponta a relação dialética com o seu criador, inventor do computador, o único capaz de contemplar e imputar novos programas, interpretar e modificá-los, ou seja, proceder a uma intervenção e, assim, aprender com a máquina também. A atitude deste sempre entra na composição da imagem. Ver uma imagem significa 
estabelecer uma relação dialógica com ela que não se reduz a um juízo de valor imediato. A imagem existe para o outro e deste emana toda a complexidade do ato de interpretação. As construções de significados dependerão, no final das contas, do locus de enunciação (Bhabha, 1994) do intérprete, ou seja, da capacidade de perceber que é sempre possível expandir a criticidade, pela estratégia do questionamento (Cervetti \& Pardales \& Damico, 2001); pela escola da suspeita de significados já legitimados (Ricoeur, 1978) e pela desconstrução (Derrida, 1979); tendo em mente que as imagens nos ensinam valores culturais; de sua mente tipográfica ou em rede (Castells, 2006: 448), desta vez em redes que se entrecruzam, retaliando e transformando as imposições ideológicas provenientes do meio meramente escrito. E se a imagem sintética do mundo digital constitui-se numa oferta para ser lida ideologicamente, sofrendo as transformações que seu meio lhe proporciona, então, resta-nos adotar uma atitude pró-ativa com as referidas preocupações epistemológicas, conforme descrevi anteriormente, diante da prática de leitura de imagens.

Nos olhares dos hiperleitores, tem-se possibilidade de suplementação (Derrida, op. cit.) das próprias significações e conexões com a sociedade digital da qual pertence. Suas linguagens mesclam escrita e imagens num movimento tridimencional, pois somente quem conhece o jogo tridimencional, como prática visual, consegue aproximar e distanciar a janela da casa, a tela do computador, passando pela porta, em direção à praia, mas, também à montanha. Evidencia-se, assim, o fato de que a nossa mente opera em tais níveis, compondo uma lógica em rede pronta para clicar em uma das subpastas, já abertas. Quem observa e vai um pouco além, sente a autonomia para lidar com o hipertexto da pintura, graças ao conhecimento prévio desse gênero de experiência.

Não se trata de simples sobreposição de telas e camadas. A tridimencionalidade está latente e pronta para futuras decisões. A arte inacabada, assim se comporta, sem origem em si nos conduzindo às múltiplas direções de leituras, novos clicks, dependendo da habilidade, do conhecimento cultural e das decisões imprevisíveis do analista. Ela somente pode ser apreendida em seu ambiente contextual em que o microcosmo dialoga com o público. Em suma, cada parte interage com outra e influencia a composição geral. 
Não se pode esperar transparência ou clareza de linguagem sendo que estes representam pressupostos de uma concepção convencional de linguagem e de interpretação. No que se refere à capacidade humana de interpretação e do meio em que a imagem foi gerada. Além do mais, o ato da percepção humana é anterior a qualquer forma de verbalização desse processo, o que significa dizer que a significação da imagem irrompe antes da estruturação verbal (fala, escrita, linguagem não verbal) por meio da qual relataremos nossos sentidos construídos durante o processo perceptivo. Trata-se de um interconexão entre pensamento, conhecimento e linguagem, sendo somente possíveis de serem inculcados mediante o crivo da linguagem. É como se nada estivesse fora do âmbito da linguagem. Ler o mundo através da linguagem. A experiência perceptiva já é um processo de construção imaginária de significados atrelados a uma prática social.

As atividades humanas se engendram em condições contextuais históricas que nos ensinam conceitos de emoções, sentimentos e reflexões. As linguagens com as quais nos socializamos modelam e recortam a percepção da realidade de uma determinada comunidade. Por exemplo, segundo Schaff (Apud Blikstein, 1995:56-57), os esquimós vêem trinta espécies de neve porque assim concebem a sua realidade. Portanto, as realidades, em sua forma pluralizada, são fabricadas, de acordo com convenções sociais previstas em uma determinada comunidade, de acordo com as influências da maneira com a qual concebemos a relação com os outros numa dimensão sócio-cultural.

Na percepção da imagem da pintura de Magritte, os hiperleitores utilizam lentes sociais que abrem diferentes janelas e/ou portas para diferentes realidades. A sociedade os ensina a crer em certas percepções (desafios cada vez maiores para conciliar tudo rumo ao topo da montanha, sem pirar; sensação de bagunça, mal organização e falta de espaço...ligada à vida moderna; o mundo da informática é exatamente isso, a transmissão de muitos dados ...ao memso tempo), e não em outras, na busca constante pela “fonte original”, pois pode haver crenças no fato de que haveria uma imagem da qual todas as outras emanam e se suplementam em diferentes formas de narrativas imagéticas. Contentamo-nos com o fato de que não há uma matriz, fonte primeira da qual construímos as imagens subseqüentes, simultâneas e múltiplas, tais quais são percebidas digitalmente. A natureza dinâmica da linguagem e o caráter fluido do meio digital trabalham em conjunto, favorecendo e reforçando a minha tese de que navegar é e não é preciso apontando para o fato de que as construções de 
realidades por parte dos hiperleitores operam de forma hipermodal, transmodal, e portanto, dinâmica, em velocidade espantosa, algo que no papel seria inconcebível.

Temos como resultado que, os atores que participam da interação multimodal compõem: o artista Magritte, o designer gráfico, o hiperleitor diante da tela, aquele que a acessou deixando a pasta aberta (xgm) e Cyberbob (editor), quem escaneou a obra artística, tanto da fonte impressa (livro), quanto da galeria virtual do artista para armazená-la em um arquivo minhas imagens e, em seguida, para a página de Webnarah e os hiperleitores participantes dessa pesquisa. A todos, o alvo é a tela recriada e ainda as interfaces, ou seja, o nosso próprio monitor (que dá acesso a Webnarah), teclado e mouse (de nossa escrivaninha e os mesmos sendo imaginados, operando o computador da recriação artística). Daí emergem diferentes hiperleituras que vão compondo uma narrativa espiralada e cujos sentidos são atribuídos a partir de seus constructos sócio-ideológicos, refletindo o locus de enunciação de cada intérprete. Interpreto que tais hiperleitores estão num desenvolvimento de criticidade, não de forma linear, porém, complexa e dinâmica no qual percebe-se uma oscilação entre o pensamento moderno, convencional e a reflexão questionadora e crítica. Como produtos de múltiplas realidades e culturas híbridas, suas identidades e linguagens são também relacionais, mas sem dúvida, há traços de incertezas relacionando experiências do cotidiano e do mundo social.

Um outro momento em que os hiperleitores compreendem e dialogam com a imagem atrelada às animações da tela surgiu em discussões referentes aos vídeo games. Relembro o leitor que tais jogos constituem um dos meios pelos quais os aprendizes constroem conhecimento durante o processo de aprendizagem, sem que tenha “modelos”' e experiência prévias, conforme esclareci na introdução desta tese.

Nesse universo, os “immigrants” (nascidos antes da década de 90), aqueles que não jogam vídeo games por vários motivos na concepção de Prensky (2006), preferem ler informações de formas lineares, textos gráficos, lêem manuais, imprimem documentos, antes de editá-los, e dispõem de mais paciência para ouvir palestras, diferente dos "natives”' (nascidos após a década de 90). Chamo a atenção para o fato de que tal divisão poderá ser problemática da perspectiva de multiletramentos, previstos por Lankshear, Knobel (2005); Cope, Kalantzis 
(2000); da perspectiva das implicações dos conceitos de suplemento e différence de Derrida (1979); da perspectiva da hermenêutica crítica de Ricoeur (1978). Tais perspectivas acentuariam uma presença de criticidade na prática digital por parte dos imigrantes, pois estes e não apenas os nativos, também praticam uma linguagem que já é concebida como sendo multimodal e por meio da interação com filmes, jornais e revistas, de fato existe a possibilidade de aprendizagem de letramento digital, de aquisição de epistemologia de performance $^{44}$, defendida por Lankshear, Knobel (2005). Em outras palavras, a linguagem multimodal e a natureza múltipla da identificação humana e a característica geradora da cultura pré-existem à máquina.

Apesar de construírem histórias a partir desse novo artefato cultural - os jogos eletrônicos - os hiperleitores da presente pesquisa oscilam entre as posições de imigrantes e nativos e muito apressadamente se limitam a dizer que o GTA é intrigante, envolvente e que possui um design que permite que o usuário escolha a estação de rádio que deseja ouvir enquanto conduz o carro; os gráficos são bons; é possível assumir a identidade de ladrão de carros, prestando serviços a traficantes e cafetões por meio de operações violentas. Observa-se a criticidade dos participantes na interação com jogos que reforçam, por exemplo, a controvérsia causada pela temática da violência (apêndice 15), como explica Trixie:

O que é admirável é as pessoas não usarem esse talento para fazer jogos que ensinem coisas boas, e não roubar e matar pessoas por fama e dinheiro; há o perigo de tornar essa idéia natural, parte da vida e aceitável. Isso já vem ocorrendo com a violência posto que torna-se mais banal a cada dia. Pessoas mortas no noticiário são algo banal. Até de manhã se pode ver séries ou filmes na TV aberta em que há violência física e psicológica.

Aparentemente, o grande imã que atrai milhares de jogadores é exatamente o tema da violência trazendo a sensação de matar (apêndice 16), conforme discorre Jean-unesp:

\footnotetext{
44 Relembro o leitor que essa concepção diz respeito a incrível capacidade de jogadores demonstrarem conhecimento construído e habilidades desenvolvidas durante a prática de letramentos, especialmente o letramento digital. Nessa construção contingencial, não há modelos pré-estabelecidos com os quais os jogadores pudesssem se basear.
} 
... adoro o San Andreas, jogo em $1^{a}$. pessoa, politicamente incorreto e violento para o PS2... Talvez porque seja interessante viver outra vida (a virtual) pois tem-se assim mais oportunidades de se viver como queira, talvez encontrar liberdade que muitas vezes não temos na chamada 'realidade'. Todos gostam de brincar de Deus, criar e comandar um indivíduo e o pior é que acabamos por acreditar muito nisso.

De fato, parece que os hiperleitores com experiência nos referidos jogos vivem uma grande ilusão achando que é realidade ou vice-versa. A teoria de Castells (2006) vem se confirmando no meio digital que borra o que é ser real e virtual. Independentemente do tema da violência, a oportunidade de articular em meio às múltiplas e dinâmicas formas identitárias ao tomar rápidas decisões nesses jogos, aproxima tais jogadores da epistemologia performativa sustentada por Lankshear, Knobel (op. cit.); do caráter de aprendizagem situada, contextualizada, ressaltado por Gee (2003), Prensky (2006).

Na perspectiva crítica de Jean-unesp (...adoro o San Andreas em $1^{a}$ pessoa, politicamente incorreto e violento) e de Rodgar (...oportunidade de se viver como queira, talvez de encontrar liberdade que muitas vezes não temos na chamada 'realidade', Todos gostam de brincar de Deus...) identifica-se uma suspensão da crença numa representação de vida baseada em concretude; há uma aparente sensação de que tudo vale, mas a contextualização e as regras da estruturação do jogo, os devolve para o interior do jogo. É como participar do sistema do jogo, ao mesmo tempo em que expressam essa possibilidade de afastamento das regras para, então, promover rupturas por meio da construção de partidas e lances únicos. Cada vez que brinca de deus, brinca diferentemente; em meio à violência, morrer é também morrer de várias formas, mas com a possibilidade de viver de novo.

Aparentemente, na reflexão em rede, construída por esses hiperleitores, há uma dialética, uma concepção local, temporal, social que avalia e interage com o mundo de forma não mais binária, mas múltipla e simultânea. Assim, Rodgar parece ilustrar a concepção de autoria sustentada por Gee (op. cit.) ao relacionar o caráter ideológico do jogo e sua esperiência. Sua percepção se expande ao verificar que é possível compartilhar do poder do designer e de sua autoria ao fazer escolhas e novamente raciocinar a partir dos efeitos provocados por decisões durante o trajeto do jogo de sentidos. Salvo engano, nas instruções de GTA não há indícios de 
que o jogador poderá brincar de deus, ou seja, essa descoberta e apreensão são resultados de uma observação e experiência dos “novos” letrados.

Nesse momento vale a pena esclarecer o fasto de que esta investigação possa ter gerado no leitor a expectativa de encontrar mais dizeres sobre vídeo games por parte dos hiperleitores para comprovar as teorias aqui apresentadas. A discrepância entre dados e teorias, ou seja, a tentativa tradicional, típica da pesquisa empírica, em procurar o monologismo num diálogo nos convida para novas reflexões sobre a relação entre ontologias convencionais e novas epistemologias, como uma demanda da sociedade digital. Na introdução desta pesquisa, enfatizei a necessidade de se aprofundar nos estudos sobre novas linguagens, novas formas de comunicação e, portanto, novas formas dee construção de sentido. O meio digital favorece à construção de sentido semelhante ao que ocorre com a oralização, conforme os estudos de Menezes de Souza (2003). A escrita já foi uma tentativa de fixar a oralidade. O que é específico na oralidade é a interação sujeito-sujetio, a imediatez. O texto escrito pode ser transportado ao passo que a oralidade é efêmera, face-a-face, em tempo real. Isso transforma as formas de saber, afetando os conceitos de verdade e mentira. A crítica ao processo de interpretação é que ela trata de um vale tudo, mas não o é. Cada espaço de interação é regido por regras, ou seja, por núcleos que irradiam convenções, havendo, assim, parâmetros de verdades em cada contexto.

Conforme dito anteriormente, a metodologia que norteia esta pesquisa é de natureza exploratória (Gee, 2004) que leva em consideração as contingências, a pluralidade de autoria e os traços, não comprovações empíricas com conclusões fechadas. Rompimentos com expectativas, interações por meio do silêncio (como as dos lurkers), portanto, fazem parte do processo neste tipo de pesquisa. Nessa perspectiva epistemológica, os dados não dariam mesmo conta das teorias. O pressuposto é a concepção de construção de conhecimento como sendo incompleta, paradoxal e dinâmica tal como a lunguagem.

Retomando o assunto jogos, para os educadores, algumas sugestões preliminares são lançadas para a reinvenção da escola para este século, tendo em vista que os designers estão usando inteligência artificial para adaptar os currículos a certos jogos, os quais mesclam diversão e aprendizagem, como dito anteriormente. Exemplo disto, Objection é usado por estudantes de 
direito para objetar, ou não, num determinado julgamento. A respeito dessa perspectiva temática, algumas perguntas devem ser encorajadas pelos educadores, quais sejam: Alguém joga algum jogo relevante para essa discussão? Que jogos ilustram esse ponto de discussão? A que interesses esses jogos atendem? Além disso, refletir, planejar e conhecer bem os jogos e criar os próprios jogos com o auxílio de aprendizes; levar outros jogos comerciais para a sala de aula; visitar sites de educadores que já promovem a aprendizagem vinculando vídeo games à sala de aula; considerar a instalação de jogos nos computadores da escola com senhas para controle do professor; promover tarefas em grupos, on-line, inserindo um determinado jogo; modificar a arquitetura da sala de aula com diferentes posições para as carteiras; engajar aprendizes dando credibilidade àquilo que estão aprendendo fora da sala de aula; aprender a ensinar a si mesmo e aos outros num processo sem que haja, necessariamente, a presença de um professor, instrutor, ou seja, o processo que Prensky (2006) denomina de disintermediation. Disintermediation se refere à eliminação do intermediário, representado pela figura do corretor de imóveis, por exemplo. Segundo o citado autor, no mundo dos negócios imobiliários, o comprador pode proceder a visitas ao imóvel que está especulando através de verdadeiros tours on-line, dispensando, assim, o corretor. A comercialização do capital agregado dos nativos, com vistas a custearem seus próprios estudos, é também prevista por Prensky (op. cit.).

Magnani (2008) resalta que os jogos são objetos culturais que disseminam valores e apagam outros e visam ao lucro. Sua abordagem crítica procuraria envolver as condições de produção de um determinado jogo, como produto da indústria cultural globalizada. Para tal, o pesquisador defende haver a necessidade de se indagar se os designers e hiperleitores estariam empenhados em questionar o status quo, se estes têm a consciência de que o locus de enunciação de cada agente influencia a construção de sentidos, se são capazes de identificar as ideologias que estão sendo articuladas nas aparentes estruturas, assim como as premissas nas regras do jogo, trazendo outras leituras ao texto vídeo games.

Chega-se, assim, a uma outra compreensão do trabalho do educador, o de promover rupturas no olhar, frente a esses novos desafios da sociedade contemporânea. A utilização do vídeo game representaria um dos instrumentos oportunos, tanto quanto fora a televisão (e ainda o é ou pode ser?) para o jovem desenvolver o seus letramentos. Seu letramento crítico poderá ser expandido por meio das concepções de ruptura de Ricoeur (op. cit.) e de desconstrução de 
Derrida (op.cit.). As referidas noções, discutidas ao longo desta investigação, partem da premissa de que as interpretações fazem sentido quando estão diretamente vinculadas ao fazer e ser do hiperleitor, como um projeto incompleto buscando interpretações inovadoras, mediante conhecimento ou perspectivas mais expandidos.

Vimos ao longo de todo o processo dessa pesquisa que a questão que parece de fato constituir-se em objeto de preocupação é, antes de mais nada, como cada hiperleitor negocia com as produções da Internet; suas particularidades em diferentes contextos de uso. Por acaso, conforme esclarecido nessas páginas anteriores, os vídeo games têm monopolizado a atenção de milhares de hiperleitores na era pós-digital, marcando o encontro de hiperleitores de longínquas partes do globo. Renova-se a maneira com a qual cada um participa ideologicamente da sociedade mediada pelo digital, ou seja, como cada um promove rupturas nos paradigmas convencionais de saber e poder, trazendo outras narrativas e, portanto, valores culturais outrora marginalizados, ao mesmo tempo em que estes hiperleitores modificam a máquina. Um hiperleitor poderá romper com as regras de um determinado programa, jogo ao perceber que os hiperlinks são consruídos para favorecer a determinados nichos ideológicos, instituições de poder. Tornar a experiência de construir significados de forma expandida e significativa para si, já embute a possibilidade de uma vasta gama de diferenças culturais interpretativas, suscitadas pela atribuição de sentidos à palavra significativa. 


\section{Considerações finais}

A história de letramentos vem rapidamente passando por profundas mudanças no mundo inteiro, respeitadas as diferenças locais. Percebe-se que em várias áreas de ensino no Brasil, os letramentos ganham prestígio no atual cenário e a necessidade de sua ampliação parece ter um certo reconhecimento na sociedade global. Tal contingência repercute no âmbito das transformações identificadas nas políticas de uma universidade que se apresenta como empreendedora de responsabilidade social, cidadania e atuação nos mercados tecnológicos emergentes da economia mundial. O que temos diante dos olhos e por trás das lentes é o fenômeno da expansão vertiginosa de diferentes formas de aprendizagens como “sabotagem”, do ensino circunscrito à sala de aula. É nesse contexto que a pesquisadora da presente tese buscou inteirar-se das atualizações globalizadas e situadas ao mesmo tempo.

Em pesquisas sobre escolas australianas, Snyder (2008) verifica que não são poucos os professores que continuam a seguir rigorosamente conteúdos, materiais e metodologias ancorados em um currículo padronizado. Contrário a essa tendência, Gee (2005) prevê a revisão de um currículo que considere os processos de aprendizagem a partir das especificidades contextuais do ambiente nos quais participantes de diferentes identificações culturais interajam de forma a contribuir com seus saberes e autorias.

Esta tese, intitulada Letramentos na sociedade digital: navegar é e não é preciso, trouxe uma ruptura epistemológica, ou seja, uma reflexão ao conceito de autenticidade. Autenticidade esta concebida não mais pela comprovação empírica com dados revelando as teorias, mas sim, dados que sinalizam, sugerem apenas traços de hibridismo produtivo nas considerações finais. Bogs e sites de relacionamento também poderiam ter fornecidos dados semelhantes, sem garantias de resultados empíricos.

Assim sendo essa vertente que focaliza a produção de conhecimento culturalmente situado tem demonstrado ser favorável às propostas da hermenêutica crítica de Ricoeur (1978) à da desconstrução de Derrida (1979). O reconhecimento da leitura como prática social requer a sustentação de suas bases segundo os pressupostos do letramento crítico e dos 
multiletramentos (visual, midático, multicultural, digital). A aplicação de habilidades e conhecimento previamente experimentados não necesariamente atende às novas demandas sociais. Reconhece-se, agora, a oportunidade de gerar ações sociais em meio a uma multiplicidade de agências, contingencialmente concebidas por parte dos hiperleitores. Estes, cada vez mais, indicam que é possível exercer autoria, e, o meio digital é favorável a essa expansão de produção cultural, sem que tenham frequentado cursos de qualquer natureza.

Foi refletindo sobre tais questões educacionais (prática de saber e poder não escolarizada) que a tese da presente pesquisa, Letramentos na sociedade digital: navegar é e não é preciso, procura chamar a atenção para as construções de sentidos articulados em um meio diferenciado da sociedade globalizada que, no entanto, mantém suas características heterogêneas. Assim é o meio eletrônico-digital, no qual uma nova bússola constrói-se, pressupondo uma performatividade mediante conhecimentos e habilidades mais elaborados. A bússola de outrora, predominantemente concisa, linear, cartesiana e empiricamente concebida para destinos previamente estabelecidos, convive com uma outra; esta, agora, não se apresenta com a característica da precisão costumeira; apresenta-se como objeto e sujeito, operando nos interstícios online e offline; no virtual e real; no global e local; no privado e público; no convencional e inovador, tanto quanto seu interlocutor-autor: o hiperleitor, participante dessa pesquisa.

Como sugerido no próprio processo desta tese, a Internet e sua linguagem favorecem a prática de letramentos diferenciados por parte do hiperleitor, reforçando que a herança derridiana do suplemento de sentidos, o qual está sempre sob rasura, pareceu manifestar-se, em vários momentos, nas discussões propostas em webnarah.pro.br/old e a escrita que dali resultou. Tais narrativas foram, aparentemente, suplantadas num espaço de afinidades no qual os hiperleitores se permitiram desconstuir dicotomias rígidas entre autor e leitor. Houve a possibilidade de transmutação atuando como co-produtor de sentidos em meio a animações, sons e imagens numa velocidade que se assemelha à da inteligência artificial. Nesse momento, possivelmente, ocorreu uma emancipação da mente acostumada a operações lineares, passando a lidar com o inesperado e a multiplicidade simultânea das escolhas, respeitadas as limitações da máquina, como sempre. 
No âmbito educacional, o letramento crítico digital vem sinalizar que os hiperleitores têm a capacidade de perceber que: houve uma mudança na rotina provocada pela saturação social; as transformações nos meios de comunicação requerem um desenvolvimento de habilidades e de conhecimento constantes; há riscos de exclusão social se não acompanharem os avanços tecnológicos; há um espaço no qual podem exercer poder e autonomia mediante habilidade e conhecimento adequados para a condução de um jogo de computador; são capazes de interagir com “estranhos" compartilhando o mundo privado a exemplo do que aconteceu quando teceram sobre o medo de serem excluídos socialmente, o medo de crime cibernético, a ansiedade perantem o futuro complexo, os desapontamentos em relação à situação políticaeducacional do país e em relação à diversidade cultural, arte, charges, jogos, lendas e notícias em geral. Mesmo os espiões que optaram por observar webnarah.pro.br/old não ficaram do lado externo do discurso. Os participantes que se engajaram indiretamente acabaram por cobrar mais eficiência na prestação de serviço quanto ao funcionamento do referido site, por meio de e-mails sugestivos de ideias e auxílio.

Houve indicações de que tais hiperleitores trazem consigo um currículo próprio de seus loci, como afirma Gee (2005) ao discorrer sobre aprendizagem situada. Eles revelam familiaridade com o uso de celulares, e-mails, mensagens de texto, i-pods, MP4, websites, DVDs, imagens e jogos de computador, mídia impressa. Esse arsenal de conhecimento e habilidades foi aplicado durante o processo de construção de novos conhecimentos no espaço de afinidade em que compartilharam performatividade típica do meio digital, idéias acerca de temas delicados e polêmicos; experiências pessoais; uma predisposição para colaborar com tais produções culturais e fazê-las fluir sem um fim previsto.

A Internet, como meio de profusão de construções multimodais, embora limitada, do ponto de vista tecnológico, lançou as decisões dos hiperleitores num espaço de constante vir a ser. As escolhas no ato da construção narrativa online vieram alterar os efeitos epistemológicos até então concebidos no papel. O meio eletrônico-digital tem provocado mudanças, as quais desestruturam o paradigma tradicional no que concerne à lógica de produção e disseminação de conhecimento, como também nas formas de reflexão teórica relativa às noções de virtualidade/realidade. Chama atenção, ainda, o surgimento de outros modos de realizar pesquisas no ciberespaço, resignificando novos (já nem tanto?) conceitos. Dentre esses conceitos destacou-se, nesta investigação, o de epistemologia digital. 
Em concordância com Lankshear, Knobel (2005) quando estes sustentam que o meio eletrônico-digital são espaços oportunos para novos letramentos, como prática social, vimos que as ofertas de direções múltiplas em webnarah.pro.br/old reforça a impossibilidade de transformar as narrativas do hiperleitores em uma única. Numa época em que se demandam rápidas atribuições de significados e articulação técnica, aproximando interpretações e produções textuais, esta tese prestou-se a investigar as transformações ocorridas por conta do capital cultural e performativo desses jovens participantes desta pesquisa, os quais não necessariamente adquiriram tal capital por meio de instrução formal, mas por estímulos sóciocontingentes.

Atualmente, o intervalo entre comprar e usar o recurso tecnológico é mínimo. Sem proceder à leituras de manuais, os hiperleitores já se predispõem a manusear equipamentos de penúltima geração enquanto constroem sentidos e desenhos a partir de um repertório vasto de habilidade técnica, criatividade e conhecimento, muitas vezes ensinando mais do que meramente aprendendo sem referências previamente articuladas.

Assim as navegações procedem, propiciando novas tensões e subversões nas quais o convívio com as ambiguidades de identidade, de linguagem, de interpretação como prática social dinâmica ganham visibilidade. Diferente do leitor convencional, o hiperleitor articula com o potencial mutante de tais ambiguidades e reforça o status de autor. Os efeitos da era digial apontam para a percepção da coexistência de produções e bens ideológico-culturais localmente concebidos.

Nesse ambiente social de intensas e surpreendentes transformações, suspeitamos daquela bússola de outrora. As meras competências técnicas e as interpretações unilaterais não mais são suficientes para negociar com as demandas atuais do mercado cultural. As diferentes práticas de letramentos contextualizados e em rede suscitam outras reflexões, desconstruções e constantes reconstruções. Nessa rede de conexões, novas interpretações, epistemologias e formas de agência social já se incluíram, transformando e se transformando. 


\section{Bibliografia}

AZEVEDO, Eduardo (relator) 2006. Parecer. Da Comissão de educação, sobre o Projeto de Lei de Câmara (PLC) $n^{\circ}$ 89, 2003. Disponível em: http://www.ibdi.org.br/index.php?secao=\&id_noticia+642\&açao+lendo. $\quad$ Acesso em: 29 Março de 2007.

BAKHTIN, Mikhail Mikhailovich 1981. “Forms of time and of the chronotope in the novel”'. In: Holquist, M. (ed.). The dialogic imagination: four essays by M. M. Bakhtin. Austin: University of Texas Press.

1999. Marxismo e filosofia da linguagem. $9^{\circ}$ ed. São Paulo: Hucitec. 2000. Estética da criação verbal. São Paulo: Martins Fontes.

BARTHES, Roland. “Authors and writers”. In: SONTAG, Susan (ed.) 1982. A Barthes reader. New York: Hill and Wang, p. 93-185.

BAUMAN, Zygmunt. 2000. Modernidade líquida. Rio de Janeiro: Jorge Zahar Editor.

BEATTIE, Bob 2001. Como ouvir música no seu PC. São Paulo: Publifolha. Traduzido por: Luís Reyes Gil.

BHABHA, Homi (Guest Editor) 1997. Critical inquiry. Front lines/border posts. Vol. 23, $n^{\circ} .03$. Chicago: The University of Chicago Press.

BIANCHI, Roberto, G. 2001. Modelo neoliberal e políticas educacionais. São Paulo: Editora Cortez.

BLIKSTEIN, I. 1995. Kaspar Hauser ou a fabricação da realidade. São Paulo: Cultrix.

BRAGA, Denise Bértoli, BUSNARDO, Joanne. 2004. Digial literacy for autonomous learning: designer problems and learner choices. In: SNYDER, Ilana \& BEAVIS, Catherine (eds.) 2004. Doing literacy online. Teaching, learning and playing in an electronic world. New Jersey: Hampton Press, INC.

BRITTON, Sheilah, COLLINS, Dan 2003. The eighth day. The transgenic art of Eduardo Kac. Arizona: Arizona State University.

BRUNER, Jerome 1986. Actual minds, possible words. Cambridge, Massachussets, London: Harvard University Press. 
BURNET, Ron 2005. How images think. Cambridge, Massachussets, London: The Mit Press. BUZATO, Marcelo El Khouri 2007. Incluídos na periferia: linguagem e letramento na inclusão digital em contextos de periferia urbana. Tese de doutorado não publicada. Campinas: UNICAMP

CARÁ JUNIOR, Jaime 2006. Relações de poder em chats temáticos com professores de inglês como língua estrangeira. Trabalho de iniciação científica não publicado. São Paulo: USP.

CARRIÉRE, Jean-Claude 2006. A linguagem secreta do cinema. Apresentação e tradução por: ALBAGLI, Fernando \& ALBAGLI, Benjamin. Rio de Janeiro: Nova Fronteira.

CASSELL, Justine, JENKINS, Henry (eds.) 2000. From Barbie to Mortal Combat. Gender and computer games. Cambridge, Massachusetts, London: The MIT Press.

CASTELLS, Manuel 2006. A sociedade em rede. Vol. 1, tradução por: Majer, Roneide Venâncio. São Paulo: Paz e Terra.

CASTELLS, Suzanne. de, LUKE, Allan, EGAN, Kieran (eds.) 1989. Literacy, society and schooling. A reader. Cambridge, New York, Port Chester, Melbourne, Sydney: CUP.

CAVALCANTI, M. C., MOITA LOPES, C. P. 1991. Implementação de pesquisa na sala de aula de línguas no contexto brasileiro. Trabalhos em Língüística Aplicada. No 17, pp 133144.

CERVETTI, G., PARDALES, M. J., DAMICO, J. S. 2001. A tale of differences: comparing the traditions, perspectives, and eduational goals of critical reading and critical literacy. Reading online, 9. In: http://www.readingonline.org/articles/cervetti/. Acesso em: 27 de Janeiro de 2004.

CLIFFORD, James. 1992. Travelling cultures. In: GROSSBERG, L. \& NELSON, C. \& TREICHLER, P. A. (eds.) Cultural studies, p.96-116.London: Routledge.

COPE, BILL, KALANTIZIZ, MARY (eds.) 2000. Multiliteracies. Literacy learning and the design of social futures. London \& New York: Routledge.

DERRIDA, J. 1997. Of Grammatology. Baltimore: The Johns Hopkins University Press. 1991. Margens da filosofia. Trad. Joaquim Torres Costa, Antônio M. Magalhães. Campinas: Papirus. 1978 Writing and difference. Chicago: The University of Chicago Press. 
DONDIS, Donis. A. 2000. Sintaxe da linguagem visual. Tradução por: Jefferson Luiz Camargo. São Paulo: Martins Fontes.

FOUCAULT, MICHAEL 2000. Vigiar e punir. História da violência nas prisões. Perópolis:Vozes.

1979. Microfísica do poder. Rio de Janeiro: Graal.

GEE, James Paul 2003. What video games have to teach us about learning and literacy. New York: Palgrave Macmillan.

1996. Social Linguistics and literacies. Ideology in discourses. London:

Taylor \& Francis, Culture \& Society.

2004. Situated language and learning. A critique of traditional schooling.

London, New York: Routledge.

GERGEN, Kenneth, J. 1991. Social Saturation and the populated self. In: HAWISHER, Gail E. \& SELFE, Cynthial, L. (eds.) 1997. Literacy, technology, and society. Confronting the issues. New Jersey: Prentice Hall.

GIROUX, Henry. A. 2002. Breaking in to the movies. Film and the culture of politics. Oxford: Blackwell Publishers.

2005. Border Crossings. Cultural workers and the politics of education. New York and London: Routledge.

HAWISHER, Gail E., SELFE, Cynthial, L. (eds.) 1997. Literacy, technology, and society. Confronting the issues. New Jersey: Prentice Hall.

HINE, C. 2000. Virtual ethnography. London: Sage Publications.

HOOFD, I. 2008. The neolieral consolidation of play and speed: ethical issues in serious gaming . disponíel em: http://www.criticalliteracy.org.uk/images/hournal/v1issue2/hoofd.pdf. Acesso em: 29 Maio de 2008.

KIM, Amy Jo 2000. Community building on the web. Secret strategies for successful online communities. California: Peachpit Press.

KRESS, Gunther , VAN LEEUWEN, Theo 1996. Reading images. The grammar of visual design. London and New York: Routledge.

2001. Multimodal discourse. The modes and media of contemporary communication. London: Arnold. 
KOSSOY, Boris 2001. Fotografia \& História. São Paulo: Ateliê Editorial.

LANDOW, George P. 2006. Hypertext 3.0 Critical theory and new media in an era of globalization. Baltimore: The Johns Hopkins University Press.

LANKSHEAR, C., KNOBEL, M. 2005. New literacies. Changing knowledge and classroom learning. UK: Open University.

LEANDER, K. M., McKim, K. K. 2003. Tracing the everyday “sitings” of adolecents on the Internet: a strategic adaptation of ethnography across online and offline spaces. Education, Communication and Information, 3 (2), p. 211-240. Disponível em: http://www.vanderbilt.ed/litspace/cvmain.html. Acesso em: 14 março de 2007.

LEMKE, J. L. 1998. Metamedia literacy: transforming meanings and media. In: Reinking, D, McKenna, M. C., Labbo, L. D., Kieffer, R. D. (eds.) 1998. Handbook of literacy and tecnology. Mahwah, NJ: Lawrence Erlbaum, p 283-302.

LEVY, Pierre 205. Cibercultura. Tradução por: Costa, Carlos Irineu da. São Paulo: Editora 34.

LUKE, A., FREEBODY, P. 1997. Constructing critical literacies: teaching and learning textual practice. St. Leonards: Allen \& Unwin.

MANOVICH, Lev 2001. The language of new media. Cambridge, Massachusetts, London: The MIT Press.

MENEZES DE SOUZA, Lynn Mario Trindade. Para uma ecologia da escrita indígena: a escrita multimodal Kaxinawá. In: SIGNORINI, Inês (org.). Investigando a relação oral/escrito e as teorias do letramento. Campinas, São Paulo: Mercado de letras, 2001, p. 167-192.

. Hibridismo e tradução cultural em Bhabha.

Voices on paper: multimodal texts and indigenous literacy in Brazil. Social Semiotics, Londres, v. 13, n. 1, p. 29-42, 2003.

In: ADBALA, Jr., B. Margens da cultura: mestiçagem, hibridismo e outras misturas. São Paulo: Editorial Boitempo, 204, p.113-134.

MONTE MÓR, Walkyria. 1999.Linguagem e Leitura da Realidade: outros olhos e outras vozes. Tese de Doutorado. São Paulo, FEUSP. 
2006. Reading Dogville in Brazil: image, language and critical literacy. In: Menezes de Souza, L. M. T. (ed.) Language and intercultural communication, vol. 6, $\mathrm{n}^{\circ}$. 2, 2006. London: Multimodal Matters.

. 2006. Investigating critical literacy at the uniersity in Brazil.

Disponível em: http://www.criticalliteracy.org.uk Acesso em: 02 de abbril de 2007.

2007. Linguagem digital e interpretação: perspectivas

epistemológicas. In: Trabalhos em lingüística aplicada. Campinas: IEL, UNICAMP, 46 (1): 1138.

MORIN, E. 1998. O método e as idéias - habitat, vida, costumes, organização. Porto Alegre: Editora Sulina.

MUSPRATT, Sandy, LUKE, Allan, FREEBODY, Peter (eds.) 1997.Constructing critical literacies. Teaching and learning textual practice. New Jersey: Hampton Press.

PARENTE, André 2000. Narrativa e modernidade. Os cinemas não-narrativos do pós-guerra. Campinas, São Paulo: Papirus.

PRENSKY, Marc, with a foreword and contributions by James Paul Gee, Ph.D. 2006. ' 'Don't bother Me Mom - I'm learning! How computer and video games are preparing your kids for twenty-first century success - and how you can help!’’ Minnesota: Paragon House.

PRINSLOO, M. 2005. The new literacies as placed resources. Perspectives in education. In: http://web.uct.ac.za/depts/educate/download/05thenewliteracies.pdf. $\quad$ Acesso em: 18 Outubro/2007.

RICOEUR, Paul. 1977. Da interpretação: ensaio sobre Freud. Rio de janeiro: Imago. . 1978. O conflito das interpretações: ensaios de hermenêutica. Rio de Janeiro: Imago.

SANGER, Jack, WILSON, Jane, DAVIES, Bryn, WHITTAKER, Roger 1997. Young children, videos and computer games. Issues for teachers and parents. London, Washington, D.C.: The Palmer Press.

SANTAELLA, Lucia, NÖTH, Winfried 2005. Imagem. Cognição, semiótica, mídia. São Paulo: Iluminuras.

SELFE, Cynthia L., HAWISHER, Gail E. Foreword by James Paul Gee. 2007. Gaming lives in the twenty-first century. New York: Palgrave Macmillan. 
SHARIFF, S. , GOUIN, R. 2005. Cyber-dilemas: gendered hierarchies, free expression and cyber-safety in schools. Disponível em: http://www.oü.ox.ac.uk/research/cybersafety/extensions/pdfs/papaers/shaheen. Acesso em: 24 de março, 2007.

SPRADLEY, J. P. 1980. Participant observation. New York, Holt, Rinehart \& Winston.

SNYDER, Ilana (ed.) 2002. Silicon literacies. Communication, innovation and education in the electronic age. London, New York: Routledge.

1996. Hypertext. The electronic labyrinth. Melbourne: Melbounre University Press.

2004. New literacies for the twenty-first century: from page to screen. Disponível em: http://www.education.tas.gov.au/English?snyder.html . Acesso em: 4 de maio, 2005.

2008. The literacy wars. Australia: Allen \& Unwin.

SNYDER, Ilana, BEAVIS, Catherine 2004. Doing literacy online. Teaching, learning and playing in an electronic world. New Jersey: Hampton Press, INC.

TAKAHASHI, Fábio. 2007 Escola particulares de S.P. ensinam ética no uso da Internet. In: Folha de São Paulo, C4, Cotidiano, 26 Março de 2007.

VAN LEEUWEN, Theo, JEWITT, Carey (eds.) 2001. Handbook of visual analysis. London, Thousand Oaks, New Delhi: Sage Publications.

VIRILIO, P. 2002. A máquina da visão. Rio de Janeiro: José Olympio Editora. 2006. The museum of accidents. Tradução de Chris Turner. In: International Journal of Baudrillard Studies, vol. 3, $\mathrm{n}^{\mathrm{o}}$ 2. URL. Disponível em: http://www.ubishops.ca/Baudrillardstudies/vol3_2/viriliopf.htm. Accesso em: 30 Maio de 2008.

XAVIER DE LIMA, L. H. M. 2007. Cotidiano em jogos: análise de jogos digitais sob uma perspectiva crítica. Disponível em: http://www.fflch.usp.br/dlm/crop. Acesso em: 26 março de 2008.

2008. Virando o jogo: uma análise de videogames através de um olhar discursivo crítico. Dissertação de mestrado. Campinas [s.n.]. 
WARSCHAUER, Mark. 2004. Technology and social inclusion. Rethinking the digital divide. Cambridge, Massachusetts: The MIT Press.

WESELOWSKI, João Renato. 2007. Como proceder em caso de crime pela Internet. Disponível em: http://poupaclique.ig.com.br/materias/090501-091000/90562_1.html.Acesso em: 27 Março de 2007.

WORSLEY, Tim 2001. Como construir um site. São Paulo: Publifolha. Tradução por Mark Suzuki. 
APÊNDICES

APÊNDICE 1

Pespuisa de doutorado:

Educaço, Linguagem Digital e Letramento Critico

Orinetanda Nara H. Takaki

Orientadora ProP De" Walkyria Monte Mct

Precisa: internautas $/$ usubrios do internet para participar de uma comunidade on line, com o objetivo de criar insumos para uma pesquisa de doutorado. Taretas. entrar num ste (criado especiaimente para a pesquisa) que contém temas variados (jogos, entretenimento, artigos, noticias, etc) escoithor 5 "textos" pce semana, lor, dar opinitho, escrever comentänos (idioma portugubs). Os nomes el identidades dos participantes serás preservados na pesquisa. Anonimidade garantida

Duracalo da participacalo: 2 mesas (B-semanas), eprosimadamente

Perfil do participante a ser imvestigado; astudante universitario, ususario de internet.

Voce gostaria de participar? Anote seu nome e e-mail na lista abojwo (legivelmente)

\begin{tabular}{|c|c|c|}
\hline 1 & 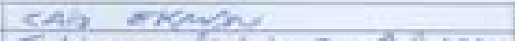 & 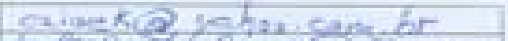 \\
\hline 2 & Tatiama de Lima Alues & 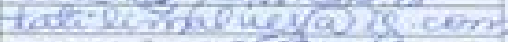 \\
\hline 3 & yopiray enturabies & 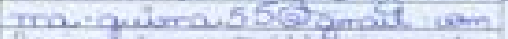 \\
\hline 4 & 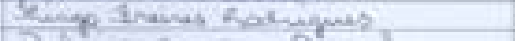 & 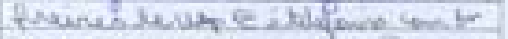 \\
\hline$\frac{5}{6}$ & 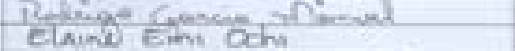 & 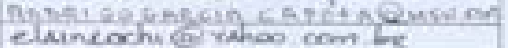 \\
\hline$\frac{6}{7}$ & Oop tondima tanon Cafies & 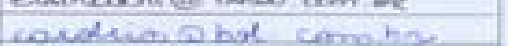 \\
\hline 8 & 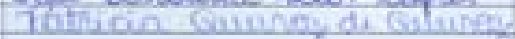 & 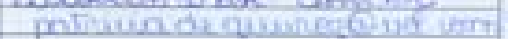 \\
\hline 9 & 60 & 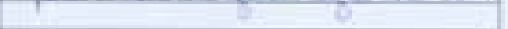 \\
\hline 10 & & \\
\hline 11. & & \\
\hline 12 & & \\
\hline 13 & & \\
\hline 14 & & \\
\hline 15 & & \\
\hline 16 & & \\
\hline 17 & & \\
\hline 18 & & \\
\hline 19 & & \\
\hline 20 & & \\
\hline 21. & & \\
\hline 22 & & \\
\hline 23 & & \\
\hline 24 & & \\
\hline 25 & & \\
\hline
\end{tabular}


Pesquisa de doutorado:

Educação, Linguagem Digital e Letramento Crítico

Orientanda: Nara Hiroko Takaki

Orientadora: Profa. Dra. Walkyria Monte Mór

Precisa: internautas/usuários universitários de Internet para participar de uma comunidade online, com o objetivo de criar insumos para uma pesquisa de doutorado. Tarefas: entrar num site (criado especialmente para a pesquisa) que contém temas variados (jogos, entretenimento, artigos, notícias, etc) escolher 5 categorias por semana, ler, dar opinião, escrever comentários (idioma: português). Os nomes e identidades dos participantes serão preservados na pesquisa. Anonimidade garantida, pois cada participante entrará com um apelido=login.

Duração da participação: 2 meses aproximadamente

Perfil do participante: estudante universitário de qualquer curso, usuário da Internet

Você gostaria de participar? Envie o seu nome completo e login para bobnation@terra.com.br (Nara). 
APÊNDICE 2

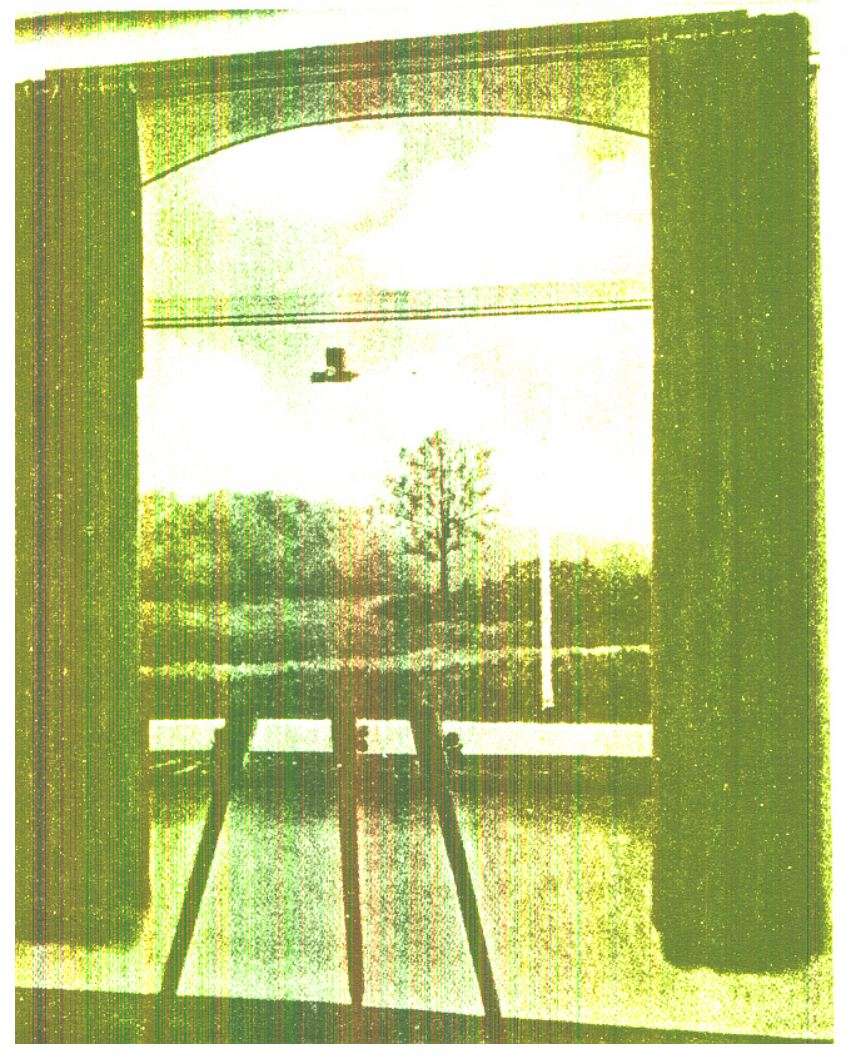

(A condição humana. Magritte)

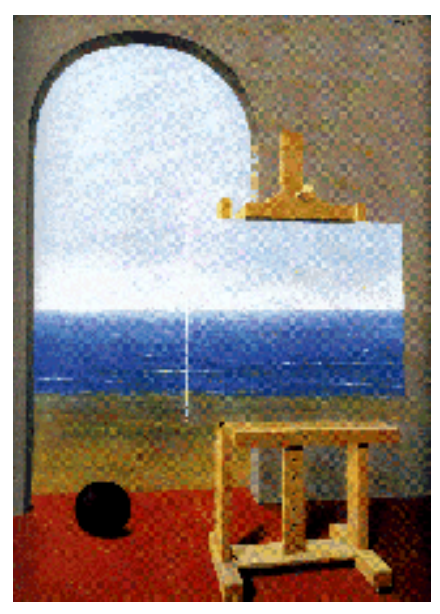


Digital Literacies and Education - Cyberbob.

CHARGES | FILMES | IMAGENS | LENDAS URBANAS | E-
MAIL | MÚSICAS | NOTÍ CIAS | GAMES | OUTROS

\section{Trapito}

Anos modernos. A atualidade..informática, projetos, ferramentas, contatos, várias tarefas ao mesmo tempo. E..desafios cada vez maiores para conciliar tudo rumo ao topo da montanha, sem 'pirar' (lê-se, não conseguir subir a montanha ou após chegar ao topo, cair no precipício).

\section{Sweet_Girl}

Bem honestamente, sugere uma tela de computador com uma linda área de trabalho (montanhas) e o quão dependente somos dos computadores e da tecnologia!

\section{nana27}

Achei uma imagem muito carregada, muita coisa misturada, apesar de não estarem amontoadas, passa uma sensação de bagunça, mal organização e falta de espaço, mas ainda sim há coisas belas presentes, como mostra a montanha e a praia. Na minha opinião, ela está ligada à vida moderna, na qual a tecnologia é essencial e está presente o tempo todo. Na qual também as pessoas tem um ritmo muito acelerado, sempre com muita coisa para fazer, pouco tempo e espaço para organizar tudo.

\section{giulia}

Realmente, uma imagem carregada. Por isso mesmo é verossímel. Afinal o mundo da informática é exatamente isso, a transmissão de muitos dados (incluindo imagens) ao mesmo tempo. 
APÊNDICE 3

Músicas:

$\odot$

Technologic

Vale a pena conferir e opinar clique aqui>

Comente:

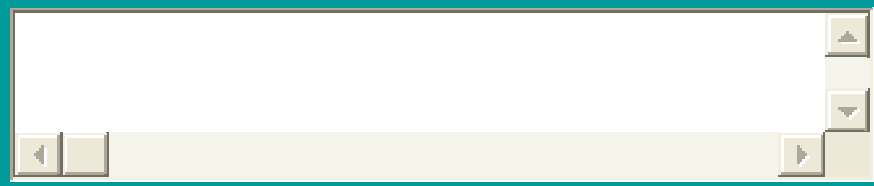

Enviar

Limpar

Temas Anteriores:

- Hip Hop

- Só deus pode me julgar

- Subúrbio

- Technologic

- Funk

- Música: Eu sou Emo

Comentários: 


\section{Sweet_Girl}

Daft: Technologic Wow... loved the song. Mostra exatamente o mundo de hoje e o que somos: escravos do que o próprio homem criou. Tudo passa muito rápido... tão rápido que nem percebemos o que realmente ocorre ao nosso redor. Lembro-me de quando eu era criança e tinha tempo para as coisas. Não havia computador, brincava na rua, não era escrava do tempo. Será que isso não faz falta para as pessoas hoje em dia? Melhor ainda: será que isso conseguirá ser substituído pelo computador e outras tecnologias futuramente?

\section{Cyberbob}

Pode ser. Quem viver verá? 


\section{Technologic}

\begin{tabular}{|c|c|c|c|c|c|c|}
\hline Buy & it, & use & it, & break & it, & fix \\
\hline Trash & it, & change & it, & Mail & - & upgrade \\
\hline Charge & it, & Point & it, & zoom & it, & press \\
\hline Snap & it, & work & it, & quick & - & erase \\
\hline Write & it, & cut & it, & paste & it, & save \\
\hline Load & it, & check & it, & quick & - & rewrite \\
\hline Plug & it, & play & it, & burn & it, & rip \\
\hline Drag & and & drop & it, & zip & - & unzip \\
\hline Lock & it, & fill & it, & call & it, & find \\
\hline View & it, & code & it, & jam & - & unlock \\
\hline Surf & it, & scroll & it, & Pause & it, & click \\
\hline Cross & it, & crack & it, & & & update \\
\hline Name & it, & read & it, & tune & it, & print \\
\hline Scan & it, & send & it, & fax & - & rename \\
\hline Touch & it, & bring & it, & pay & it, & watch \\
\hline Turn & it, & leave & it, & stop & - & format \\
\hline
\end{tabular}

Technologic

\begin{tabular}{|c|c|c|c|c|c|c|}
\hline Buy & it, & use & it, & break & it, & fix \\
\hline Trash & it, & change & it, & mail & - & upgrade \\
\hline Charge & it, & Point & it, & zoom & it, & press \\
\hline Snap & it, & work & it, & quick & - & erase \\
\hline Write & it, & cut & it, & paste & it, & save \\
\hline Load & it, & check & it, & quick & - & rewrite \\
\hline Plug & it, & play & it, & burn & it, & rip \\
\hline Drag & and & drop & it, & zip & - & unzip \\
\hline Lock & it, & fill & it, & call & it, & find \\
\hline View & it, & code & it, & jam & - & unlock \\
\hline Surf & it, & scroll & it, & pause & it, & click \\
\hline Cross & it, & crack & it, & & & update \\
\hline Name & it, & read & it, & tune & it, & print \\
\hline Scan & it, & send & it, & fax & - & rename \\
\hline Touch & it, & bring & it, & pay & it, & watch \\
\hline Turn & it, & leave & it, & stop & - & format \\
\hline
\end{tabular}




\begin{tabular}{|c|c|c|c|c|c|c|}
\hline Buy & it, & use & it, & break & it, & fix \\
\hline Trash & it, & change & it, & Mail & - & upgrade \\
\hline Charge & it, & Point & it, & zoom & it, & press \\
\hline Snap & it, & work & it, & quick & - & erase \\
\hline Write & it, & cut & it, & paste & it, & save \\
\hline Load & it, & check & it, & quick & - & rewrite \\
\hline Plug & it, & play & it, & burn & it, & rip \\
\hline Drag & and & drop & it, & zip & - & unzip \\
\hline Touch & it, & bring & it, & pay & it, & watch \\
\hline Turn & it, & leave & it, & stop & - & format \\
\hline Touch & it, & scroll & it, & Pause & it, & click \\
\hline Cross & it, & crack & it, & switch & - & update \\
\hline Surf & it, & scroll & it, & Pause & it, & click \\
\hline Cross & it, & crack & it, & Switch & - & update \\
\hline Name & it, & read & it, & tune & it, & print \\
\hline Scan & it, & send & it, & fax & - & rename \\
\hline Touch & it, & bring & it, & pay & it, & watch \\
\hline Turn & it, & leave & it, & stop & - & format \\
\hline Buy & it, & use & it, & break & it, & fix \\
\hline Trash & it, & change & it, & Mail & - & upgrade \\
\hline Charge & it, & Point & it, & zoom & it, & press \\
\hline Snap & it, & work & it, & quick & - & erase \\
\hline Write & it, & cut & it, & paste & it, & save \\
\hline Load & it, & check & it, & quick & - & rewrite \\
\hline Plug & it, & play & it, & burn & it, & rip \\
\hline Drag & and & drop & it, & zip & - & unzip \\
\hline Surf & it, & scroll & it, & pause & it, & click \\
\hline Cross & it, & crack & it, & Switch & - & update \\
\hline Name & it, & read & it, & tune & it, & print \\
\hline Scan & it, & send & it, & fax & - & rename \\
\hline Touch & it, & bring & it, & pay & it, & watch \\
\hline Turn & it, & leave & it, & stop & - & format \\
\hline Buy & it, & use & it, & break & it, & fix \\
\hline Trash & it, & change & it, & mail & - & upgrade \\
\hline Charge & it, & pause & it, & zoom & it, & press \\
\hline Snap & it, & work & it, & quick & - & erase \\
\hline Write & it, & cut & it, & paste & it, & save \\
\hline Load & it, & check & it, & quick & - & rewrite \\
\hline
\end{tabular}




$\begin{array}{lccccccr}\text { Plug } & \text { it, } & \text { play } & \text { it, } & \text { burn } & \text { it, } & \text { rip } & \text { it, } \\ \text { Drag } & \text { and } & \text { drop } & \text { it, } & \text { zip } & - & \text { unzip } & \text { it, } \\ \text { Surf } & \text { it, } & \text { scroll } & \text { it, } & \text { pause } & \text { it, } & \text { click } & \text { it, } \\ \text { Cross } & \text { it, } & \text { crack } & \text { it, } & \text { switch } & - & \text { update } & \text { it, } \\ \text { Name } & \text { it, } & \text { read } & \text { it, } & \text { tune } & \text { it, } & \text { print } & \text { it, } \\ \text { Scan } & \text { it, } & \text { send } & \text { it, } & \text { fax } & - & \text { rename } & \text { it. }\end{array}$

Technologic [4x] 
APÊNDICE 4

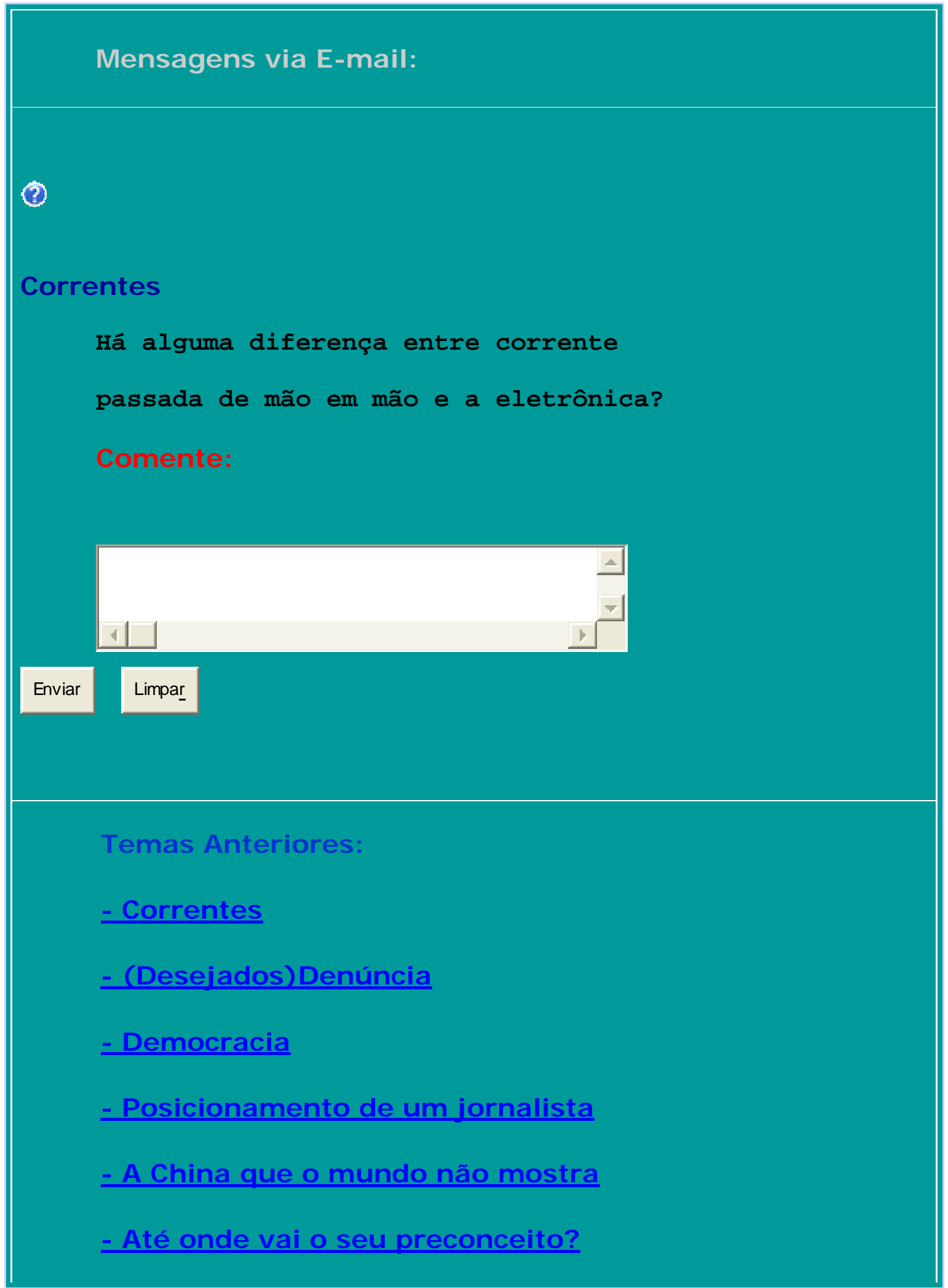




\section{Comentários:}

\section{jean_unesp}

Certamente. Todo o tipo de comunicação eletrônica não consiste em comunicação plena e ideal. Uma coisa é a troca de informações, outra é a comunicação entre indivíduos. Leiam Milton Santos.

\section{giulia}

O meio eletrônico facilitou brincadeiras como as correntes. E-mails do tipo repasse para $\mathrm{x}$ pessoas para ter seu desejo realizado ou coisas ruins irão acontecer com vc entopem as caixas postais.

\section{Ampcity}

Acho que a principal diferença reside na velocidade de propagação da corrente eletrônica. Além disso, as pessoas que recebem correntes via e-mail tendem a dar menos crédito a estas já que, por via, o acesso à Internet em nosso país ainda está restrito a um determinado nicho mais bem instruído, em tese...

\section{Cyberbob}

Dizem que, tanto os que elaboram essas infomações, correntes quanto os que respondem a elas, não têm muito há fazer na vida. Dá prá aprender alguma coisa com este tipo de interação?

\section{rodgar}

Sim, o contato direto com outro ser humano pode exprimir mais emoções, sentimentos e respostas do que no modo eletrônico, no qual recebe-se uma mensagem que está afastada diretamente de qualquer individuos (contudo muitos individuos a tenham passado e repassado) deixando apenas a mensagemm à mostra; o resultado é na maioria das vezes é que quem recebe tais mensagem apenas a deletam e sequer nem leêm, tão comum receber estas correntes, inclusive muitas repetitivas, hoje em dia. 
APÊNDICE 5

Lendas Urbanas:

()

Mensagem eletrônica intitulada I nvitation

Email enviado para você em 13/11/06 sobre virus:

Invitation. Mais uma lenda?

Comente:

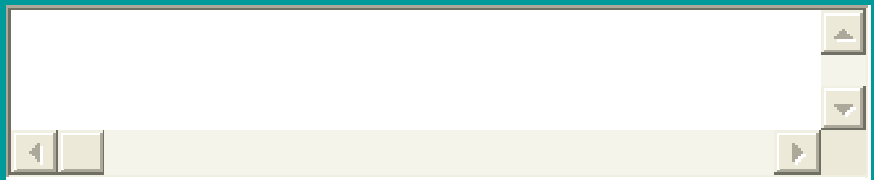

Enviar

Limpar

Temas Anteriores:

- Verdades nas mentiras, mentiras nas verdades?

- Bill Gates como anticrito.

- Ajuda para Aleksandra Kuczma

- Mensagem eletrônica intitulada I nvitation

- Desta vez, gol para quem?

- Rede Globo e Criança Esperança

Comentários: 


\section{pinkone}

A cada dia recebemos tanta coisa pela Internet, que não dá mais pra saber no que acreditar..seja aviso de virus, correntes religiosas, e durante as eleiçoes então..um bombardeio de info com dados estatisticas, vindos sabe-se lã de onde..e olha que isso decidiu opinião de muita gente..não sei se o que assusta é a quantidade ou se ainda, de não se saber a fonte..mas que gera um descomforto isso gera...as pessoas acabam encaminhando com mensagens tipo assim: não sei se é verdade mas vamos tentar..há aquelas que realmente acreditam e escrevem emails imensos sobre o encaminhado...particularmente sobre a eleição, eu entrei ewm uma discussão com uma menina via email justamente sobre esse assunto, ela me mandava varios email sobre os candidatos a presidencia, e particularmente sempre defendendo um e ofendendo o outro..então respondi perguntando a fonte..e ela começou a discutir o conteudo dos casos e nunca mencionou nada sobre a fonte..Enfim, só sei que tudo isso me leva a não acreditar mais em nada..ou pelo menos na miria da coisas que rolam..o que tb é perigoso, porque talvez haja coisas que ealmente ocorrem, no caso dos virus por exemplo...recebi um email falando num virus que tornou alguns dos dados do orkut em link..fui no orkut e vi realmente que estavam em forma de link..então apaguei todas as info..nesse caso, por exemplo, o aviso de virus (se é que era virus) foi valido. mas sõ em casos como este.

\section{nana27}

Já não sei mais o que pensar a respeito desse tipo de email. Confesso que sempre os repasso, mas não estou certa de que sejam verdadeiros. Mas a cada dia eles vão provando que não passam de uma lenda, afinal nunca recebi, nem ouvi ninguém dizer ter recebido nenhum email cujo assunto era "invitation" ou qualquer outro dos vários que aparecem nos email alertando sobre o vírus. Concordo com o comentário de pinkone dizendo que recebemos tanta coisa pela Internet que já não é mais possível saber o que é verdade e em que podemos acreditar.

\section{giulia}

Cada vez mais comuns este tipo de e-mail. Não dá mais para saber o que é verdade ou não. O jeito é tomar cuidado com os e-mails que recebemos. 


\section{Cyberbob}

De qualquer forma o alerta vale para aqueles que não acessarão tais mensagens? 
APÊNDICE 6

Outros:

$\odot$

Crimes cibernéticos

Você já foi vítima de algum tipo

de crime na Net? Qual é o seu posicionamento

em relação a esse tema?

Comente:

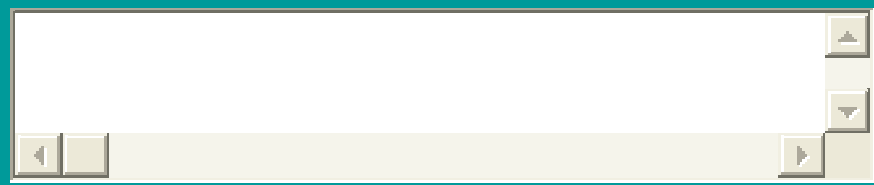

Enviar Limpar

Temas Anteriores:

- Mas afinal...

- Arte transgênica?

- Crimes cibernéticos

- Em boa hora, A louca de Chaillot - SESC Santana

- Sistema de cotas 


\section{- A doenca da magreza}

\section{- Xerazade ou Scheherazade}

\section{Comentários:}

rodgar

Bom, claro que já recebi e-mails do "governo", de "bancos" e etc, dizendo que eu devia uns tantos mil reais e que deveria enviar meus dados, depositar o dinheiro na contal tal and so far so on. É forçoso que eu diga também: crimes, já os devo ter cometido, aos milhares. Era um grande fã do site "sogratiz". Gosto da internet pois ainda há grande "Liberdade" quando se está navegando, pode-se ser tudo, fazer de tudo, sendo bom ou ruim. Contudo, existem mais caracteres esquizofrênicos do que eu imaginava: essa liberdade está acabando, e vai acabar. Bloqueios cointra download de conteúdos protegidos, orkut, e etc. Bom senso apenas não ajuda contra os crimes. Em nosso país sem educação, a única solução é: a punição, aguardem, ela vai chegar... Ai de mim...

\section{Sweet_Girl}

Não fui vítima de crimes na Net, mas de ameaças virtuais sérias via Orkut (seqüestro). Muitas vezes cremos q estamos nos desenvolvendo e progredindo. Eu tenho minhas dúvidas. Saí do Orkut, messenger , não tenho mais fotolog... tudo por medo do avanço tecnológico... contraditório, não?

\section{nana27}

Nunca fui vítima, mas como muitos, conheço alguém que já foi. Acho que tudo tem seu lado positivo e seu lado negativo, e a Internet e seus avanços têm seus benefícios, porém também trazem com eles muitas coisas ruins e às vezes acho que os avanços tecnológicos já atingiram seus limites e com isso inicia-se a regressão, como esses crimes e outras coisas. 
APÊNDICE 7

Lendas Urbanas:

(อ)

Ajuda para Aleksandra Kuczma

No lugar da família da vítima,

o que você faria?clique aqui>

Comente:

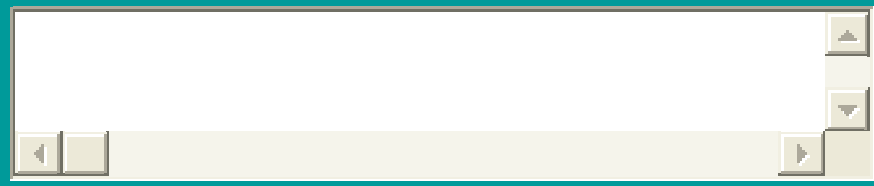

Enviar

Limpar

Temas Anteriores:

- Verdades nas mentiras, mentiras nas verdades?

- Bill Gates como anticrito.

- Ajuda para Aleksandra Kuczma

- Mensagem eletrônica intitulada I nvitation

- Desta vez, gol para quem?

- Rede Globo e Crianca Esperanca

Comentários: 


\section{jalapeño}

Talvez o fato de este caso ter se tornado público, através da TV, tenha trazido benefícios à família que acabaram por compensar tudo o que veio depois. Acho que um acidente desse tipo é tão infeliz que qualquer outra coisa se torna pequena diante dele.

\section{giulia}

Já recebi vários e-mails deste tipo. Infelizmente há todo tipo de pessoas no mundo e algumas acabam usando tragédias como essa para fazer brincadeiras de mau-gosto.

\section{Sweet_Girl}

Um insulto fazer uso de um fato tão grave e triste a troco de nada... de uma simples brincadeira. As pessoas estão se tornando tão impassíveis ultimamente que chegam ao ponto de simplesmente utilizar o fato para se divertir... até o dia em que isso ocorrer com alguém próximo ou querido a esses indivíduos. Porém, também há o outro lado: a família deve, sim, ter se beneficiado de algum modo, entretanto creio que a maior parte das pessoas apenas repassava o e-mail pensando já estar colaborando e contrubuíram apenas para o aumento de spams na Internet.

\section{wednesday}

Nao sei se há algo de fato que a família possa fazer quando um ocorrido desse ganha proporções gigantescas, o que é muito fácil de acontecer no mundo cibernético. Afnal, a internet é a terra de ninguém e é preciso bom senso dos usuários ao receberem e-mails assim.

\section{nana27}

Divulgaria a falsidade do conteúdo do e-mail, aproveitando para reforçar o pedido de colaborações. 


\section{APÊNDICE 8}

\section{Digital Literacies and Education - cyberbob.}

CHARGES | FILMES | IMAGENS | LENDAS URBANAS | E-MAIL | MÚSICAS | NOTÍCIAS | GAMES OUTROS

Notícias:

$\odot$

Vestibular

o vestibular foi acusado de engesar o ensino nas escolas e nos cursinhos (em 0 Estado de

São Paulo, A32, 26/11). Você concorda com esta afirmação?clique aqui>

Comente:

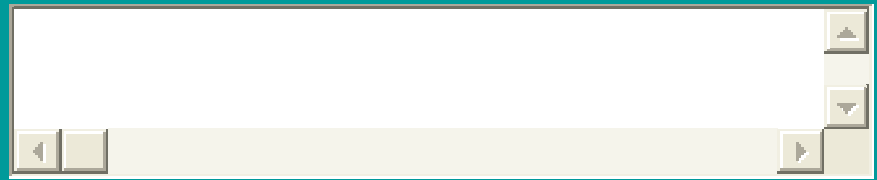

Enviar Limpar

Temas Anteriores:

- Mais protagonistas, numa mesma época, num só dia.

- Política

- "Aqui você não joga mais", diz Leão a Carlos Alberto

- Lula tentando explicar o tremendo sucesso de seu filho, Fábio Luis. 


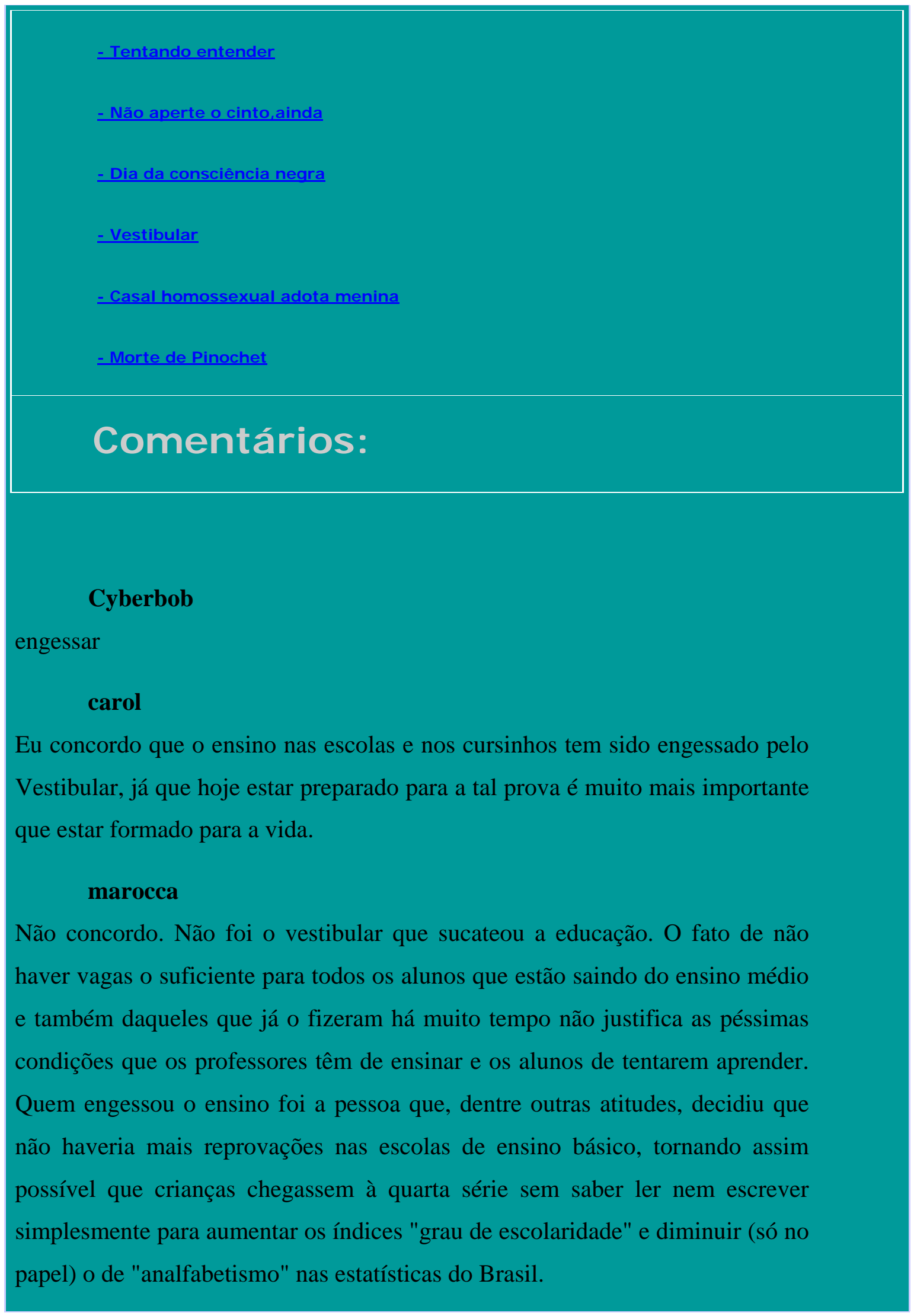




\section{APÊNDICE 9}

\section{Digital Literacies and Education - cyberbob.}

CHARGES | FILMES | IMAGENS | LENDAS URBANAS | E-MAIL | MÚSICAS | NOTÍCIAS | GAMES OUTROS

Notícias:

$\odot$

Dia da consciência negra

A primeira reunião para celebrar o 20 de novembro

com o dia da consciência negra, ocorreu em Porto Alegre, 1971.

Na capital gaúcha, hoje não é feriado.

Seus horizontes?

Comente:

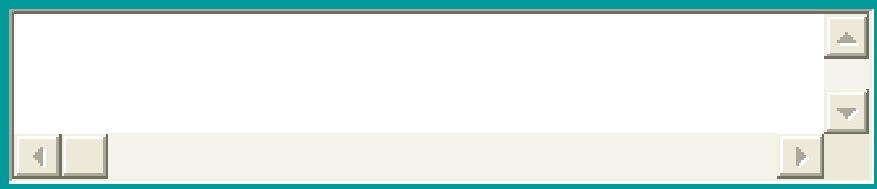

Enviar

Limpar

Temas Anteriores:

- Mais protagonistas, numa mesma época, num só dia.

- Política

- "Aqui você não joga mais", diz Leão a Carlos Alberto

- Lula tentando explicar o tremendo sucesso de seu filho, Fábio Luis. 
- Tentando entender

- Não aperte o cinto,ainda

- Dia da consciência negra

- Vestibular

- Casal homossexual adota menina

- Morte de Pinochet

\section{Comentários:}

\section{arianeconstantino}

O dia da consciencia é a maior injustiça racial da historia brasileira, nós não temos o dia da consciencia indigena, ou da consciencia branca, comemorar o dia 20 de novembro com esse nome é um fato que ofende a ideia da data. Sabese que esta é a data estipulada da morte de Zumbi, o negro simbolo da resistencia a politica, chamar o dia de sua morte dia da conciencia negra é uma vergonha a memoria deste simbolo. Acho que a morte de Zumbi deveria sim ser um feriado nacional, a figura de Zumbi é mais marcante que a de outros homenageados em feriados, mas não devemos marcar a consciencia como uma cor, como se os negros tivessem uma consciencia diferente por sua raça. Se fosse assim, deveria haver um dia de consciencia para cada cor, azul, amarela, ou até a branca.

\section{carol}

O que deveria haver era um amplo diálogo com a sociedade SOBRE a consciência negra, ou melhor, sobre a situação que o negro vive no Brasil. Definir esse dia como feriado faz com que simplesmente paremos de trabalhar, como acontece em tantos outros feriados em que a reflexão sobre aquele dia é completamente esquecida pela grande maioria da população. 
APÊNDICE 10

\section{Digital Literacies and Education - cyberbob.}

I OUTROS

\section{Notícias:}

$\odot$

Casal homossexual adota menina

Qual é o seu posicionamento?

clique aqui>

Comente:

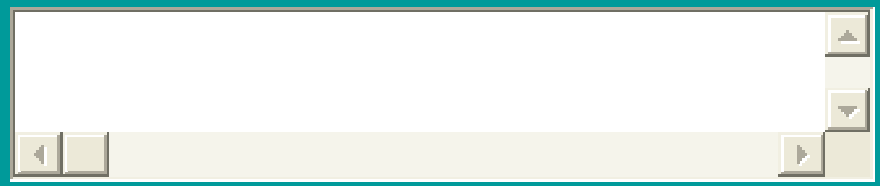

Enviar

Limpar

Temas Anteriores:

- Mais protagonistas, numa mesma época, num só dia.

- Política

- "Aqui você não joga mais", diz Leão a Carlos Alberto

- Lula tentando explicar o tremendo sucesso de seu filho, Fábio Luis.

- Tentando entender 
- Não aperte o cinto,ainda

- Dia da consciência negra

- Vestibular

- Casal homossexual adota menina

- Morte de Pinochet

\section{Comentários:}

\section{Sweet_Girl}

É, trata-se realmente de uma polêmica. Sim, o casal fez um gesto maravilhoso ao adotar uma criança e evitar que um futuro terrível fosse seu destino. Porém, será que a criança compreende o q se passa? Como ela encara a idéia da "mãe", da maternindade? E os amiguinhos, qdo perguntarem e fizerem comentários sobre o assunto? Não sei... não sou contra nem a favor. Tenho uma opinião neutra. Apenas preocupo-me com a cabeça da garota. Deve haver uma explicação clara, honesta e um relacionamento aberto com ela para que ela não fique confusa e sinta-se desconfortável.

\section{Cyberbob}

Vi uma aprte da entrevista que o casal de, na TV. Parece que ela teve acompanhamento com psicólogo, ficou com o casal por um tempo. depois disso é que a justiça oficializou a adoção. Como saber sobre o futuro dela?

\section{arianeconstantino}

O processo de adoção é um instrumento de demonstração de amor, no Brasil, ele é demorado e burocratico, como deve ser, devido a sua importancia na vida das pessoas envolvidas, os pais e a criança. Se esses dois homens não estivessem prontos para receber esta criança, este processo seria interrompido, e ela continuaria no orfanato. Se uma grande equipe de psicologos e assistentes sociais julgaram que este casal eatava pronto para receber esta criança, quem 
somos nós, sociedade brasileira para contrastar este fato. Alem disso, devemos lembrar que esta criança podera contar com dois pais, ao inves de não ter nenhuma familia. 
APÊNDICE 11

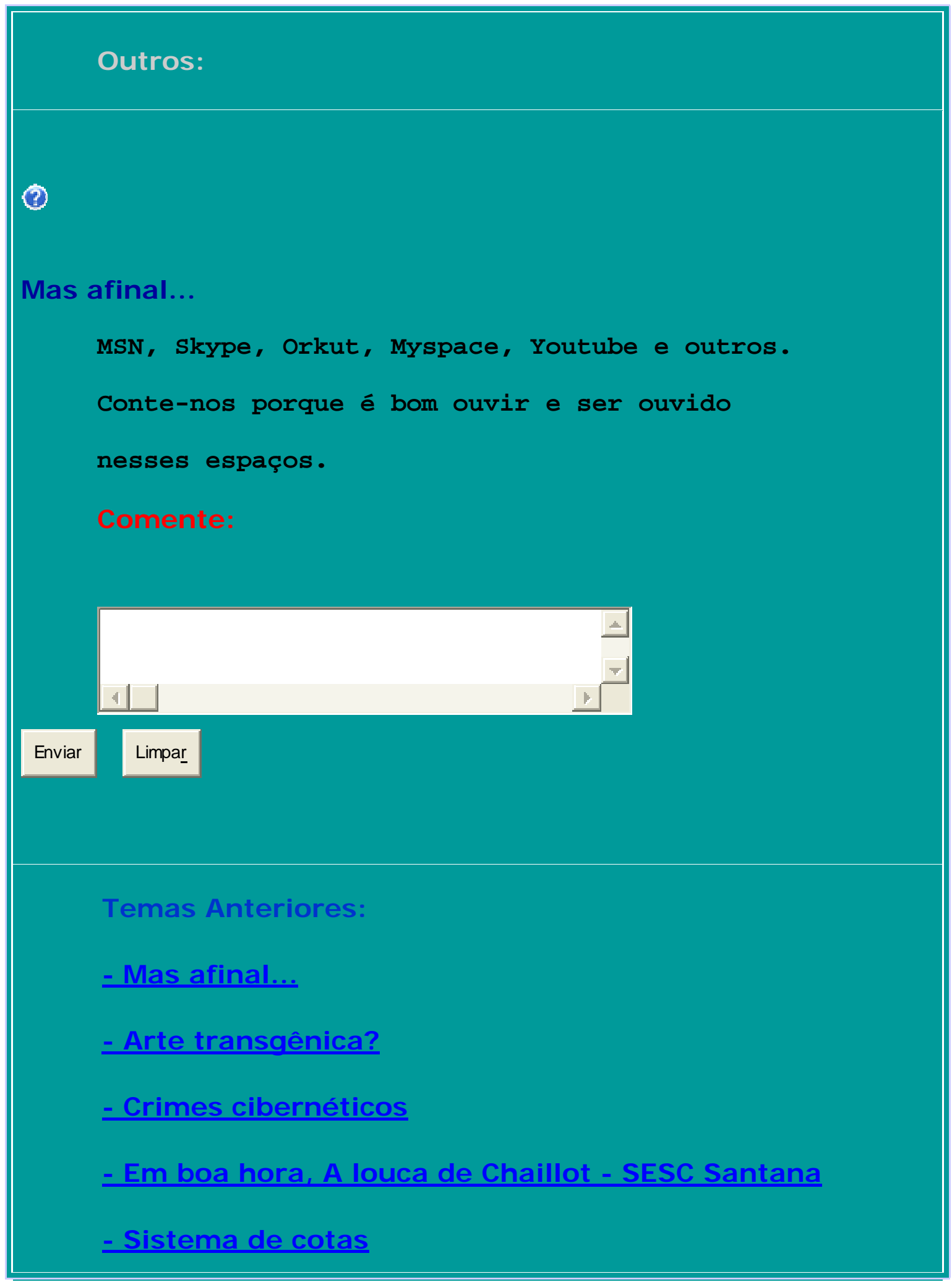




\section{- A doenca da magreza}

\section{- Xerazade ou Scheherazade}

\section{Comentários:}

jean_unesp

Não acho muito bom ou comunicativo, participo, mas sinto que é mais por obrigação pois sem esses meios as pessoas acabam te excluindo dos eventos e tal. Sempre que recebo um scrap, sinto-me obrigado a responder, as vezes nem sei o que dizer, mas tenho que responder, caso contrário sou excluído, percebe ? Já para divulgar trabalhos, eventos, oportunidades e idéias, penso que qualquer meio de comunicação é válido, por isso também participo desses "internet bugs".

\section{Ampcity}

É bom ouvir e ser ouvido nesses espaços quando nos comunicamos com pessoas de nosso meio social real, isto é, gente q vemos com frequência ou com quem mantemos algum contato presencial. A distância, por exemplo, justifica o uso do msn, o orkut, etc.. O youtube é entretenimento, afinal somos curiosos por natureza. Discordo que esses espaços sejam adequados a conhecer novas pessoas, fazer amizades, etc... Servem como mais uma forma de interação, que nem deve ser exclusiva e quiçá a mais importante.

\section{Cyberbob}

Então, mas, tudo isso aí veio prá ficar? Será que os caça talentos ficam constantemente de olho em tais espaços?

\section{giulia}

São novos meios de comunicação. Ás vezes podem até funcionar como ferramenta de trabalho. É divertido para se comunicar com amigos ou reencontrar conhecidos que não viamos há tempos. No entanto, sempre tem gente que não sabe usar. Ai vemos divulgação de racismo e preconceitos e 
coisas do gênero.

Cyberbob

Giulia, você usaria um deles em sua sala de aula? 


\section{APÊNDICE 12}

Ass

unto:

[Desejados] Não agradou?

Olá internauta

Estou preoocupada pois não apareceram as análises para a semana passada. Os temas não foram agadáveis? bem, gostaria de lembrar que é possível comentar qualquer assunto elencado dentro de cada categoria, a qualquer momento que desejar. Não se trata de uma discussão por ordem de entrada de assuntos. Sugestões, serão bem vindas.
Abçs
Cyberbob 
Ass

unto:

[Desejados] Re: Não agradou?

Olá, Nara!!

Realmente não entendi o q aconteceu e ia até te escrever pedindo ajuda. Entrei no site, mas os assuntos eram os mesmos... eu já havia comentado praticamente todos eles. Não vi esses assuntos novos q mencionou. Pensei q o site não tivesse mudado... pode especificá-los para mim, por gentileza? Entrei hj e já mudou aqui. Entro sempre por este site:

http://webnarah.pro.br/

É esse mesmo? E, a propósito, os temas são SEMPRE mto interessantes :)

Desculpe e obrigada pela atenção!

Sweet_Girl

Ass [Desejados] Res: Não agradou? 
unto:

Olá,

o motivo foi a falta de tempo msm, final de semestre é sempre uma loucura!

Mas prometo que serei mais participativa!

Nana27 
Ass

unto:

[Desejados] Re: Não agradou?

Olá Nara,

queria pedir desculpas por não ter acessado seu site nas ultimas semanas, mas devido ao final do semestre, as coisas estavam uma correria...tanto que agora, não sei onde anotei o site...parece piada, mas você me passa o site novamente..rss..eu lembro meu login, mas acredita que fui acessar e deu branco!

Peço desculpas mais uma vez,

Obrigada

Pinkone 


\section{APÊNDICE 13}

[Desejados] webnarah-questionário

Dear all

Se puderem responder ao questionário abaixo, eu lhes seria novamente grata.

1. O que levou você a participar das interações em webnarah. pro.br?

2. Houve momentos que Ihe chamou a atenção?

3. Que modificações você faria ou me sugeriria?

4. Como você interpreta o fato de que muitos não participaram?

5. Algumas das perguntas de Cyberbob não foram respondidas. Como explicar isso?

6. O que você aprendeu com essa experiência?

7. Como você encara o futuro da Internet? 
Abraços

Nara 
APÊNDICE 14

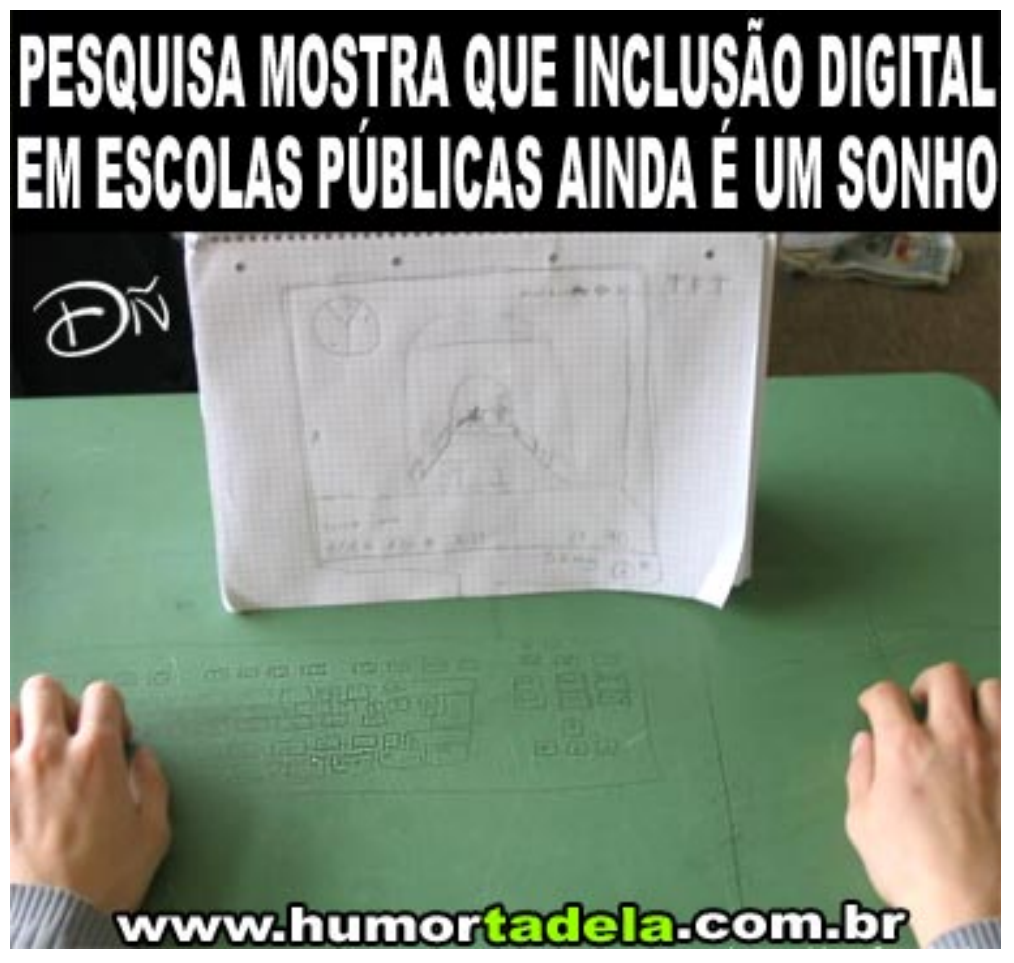




\section{APÊNDICE 15}

\section{Digital Literacies and Education - cyberbob.}

CHARGES | FILMES | IMAGENS | LENDAS URBANAS | E-MAIL | MÚSICAS | NOTICIAS | GAMES OUTROS

Games:

0

GTA San Andreas 2

o que você acha da música, do visual e da temática deste jogo? clique aqui>

Comente:

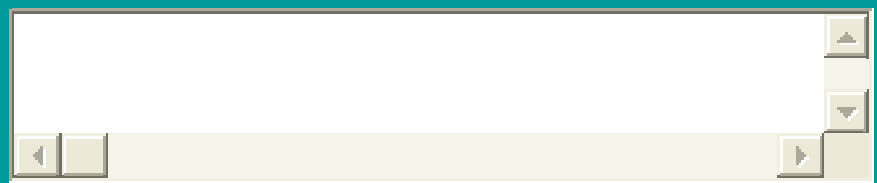

Enviar

Limpar

Temas Anteriores:

- Um bom comeco?

- Kabul Kaboom

- Setembro 11

- Bully 
- Dancing Bush

- GTA San Andreas 2

\section{Comentários:}

\section{rodgar}

Great!

\section{Cyberbob}

Por quê?

\section{marocca}

O tema central de você, personagem praticamente em primeira pessoa, ser um ladrão de carros, que presta serviços para traficantes, cafetões e vive fugindo da polícia, não me agrada, ainda mais depois de ouvir crianças dizendo que é muito legal roubar carros. Mas devo confessar que o jogo é envolvente, os gráficos são bons, e a trilha sonora você pode escolher, porque no carro é o jogador que decide qual estação de rádio quer escutar. O que é admirável é as pessoas nào usarem esse talento para fazer jogos que ensinem coisas boas, e não a roubar e matar pessoas por fama e dinheiro.

\section{trixie}

O jogo é envolvente e bem desenvolvido. Entretanto a temática é muito controversa porque parece incentivar os jogadores a se divertirem com a idéia de roubar carros. Sabemos que não é certo roubar carros, muito bem. Mas crianças são influenciáveis e tem diferente visão de realidade e brincadeira. Há o perigo de tornar essa idéia natural, parte da vida e aceitável. Isso já vem ocorrendo com a violência, posto que torna-se mais banal a cada dia. Pessoas mortas no noticiário são algo banal. Até de manhã se pode ver séries ou filmes na TV aberta em que há violência e física e psicológica.

\section{Margarida}


APÊNDICE 16

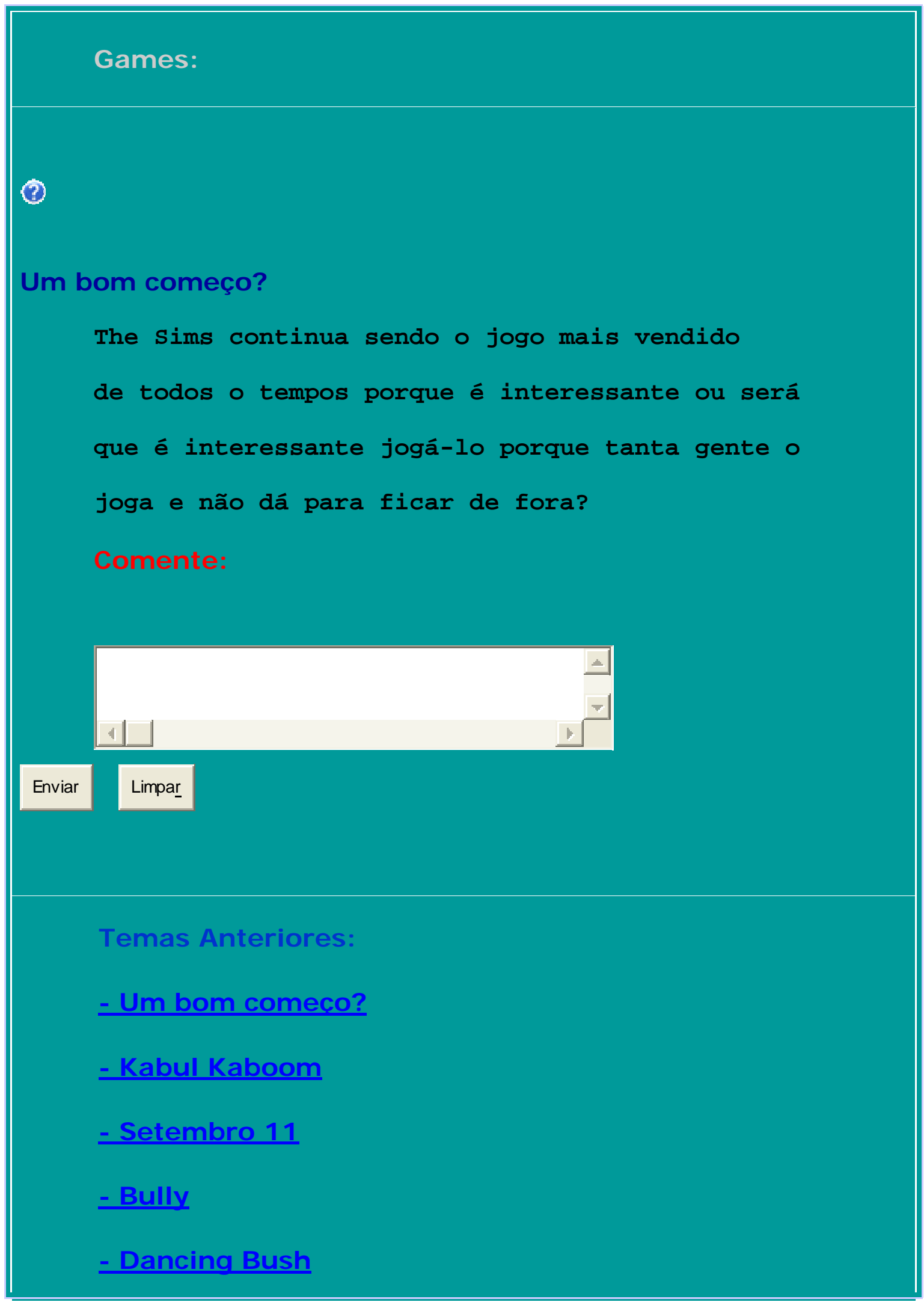




\section{- GTA San Andreas 2}

\section{Comentários:}

\section{jean_unesp}

Não sei, mas adoro o San Andreas, jogo em $1^{\circ}$ pessoa, politicamente incorreto e violento para o PS2. A interface deste jogo pode ser um bom objeto de discussão.

\section{Cyberbob}

Jean Não conheço o contexto deste jogo, daria para explicar, com exemplos, como ele funciona, o motivo pelo qual a interface seria objeo de discussão?

\section{rodgar}

Talvez porque seja interessante viver outra vida (a virtual), pois tem-se assim maais oportunidades de se viver como queira, talvez de encontrar liberdade que muitas vezes não temos na chamada "realidade". Todos gostam de brincar de Deus, criar e comandar um individuo, e o pior é que acabamos por acreditar muito nisso. Eu tambémm tenho Sims...

\section{Cyberbob}

Então Rodgar, nesse Sims eu vi lá a possibilidade de costumizar a protagonista, por os modismos na aparência, tomar decisões entre tatnata possibilidades. Mas eu senti que aquela vida não poderia ser diferente,ou seja, orientada por regras. De onde vem a imposição, o conceito de felicidade? Se usaria este jogo em aula? 